

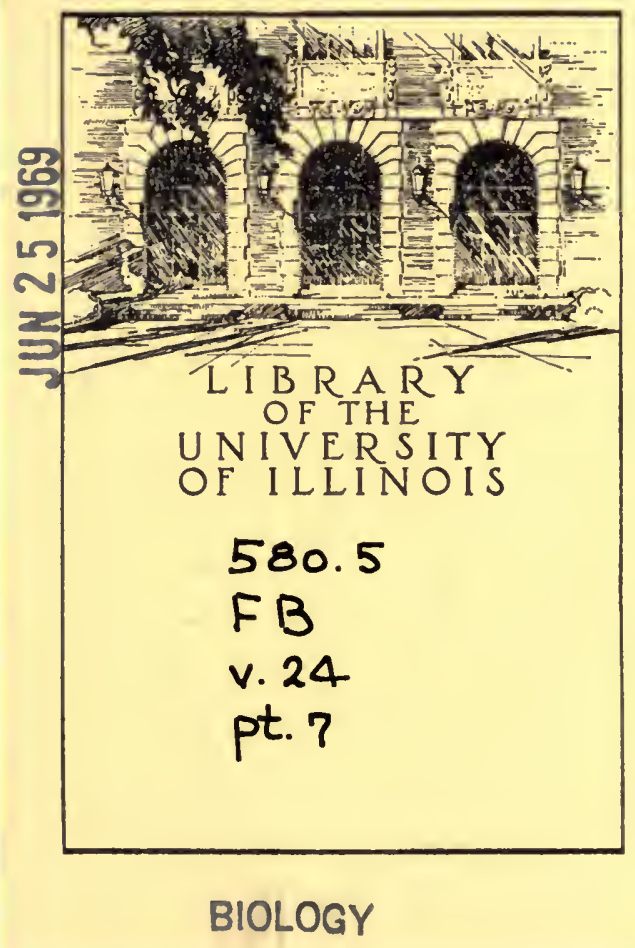






t. 1

\section{FLORA OF GUATEMALA}

PAUL C. STANDLEY

AND

LOUIS O. WILLIAMS

FIELDIANA: BOTANY, VOLUME 24, PART VII, NUMBER 1

Published by CHICAGO NATURAL HISTORY MUSEUM NOVEMBER 13, 1961 



FLORA OF GUATEMALA PART VII 



\title{
FLORA OF GUATEMALA
}

PAUL C. STANDLEY

Curator Emeritus of the Herbarium

\author{
AND \\ LOUIS O. WILLIAMS \\ Curator, Central American Botany
}

FIELDIANA: BOTANY

VOLUME 24, PART VII, NUMBER 1

Published by

CHICAGO NATURAL HISTORY MUSEUM

NOVEMBER 13, 1961 
Library of Congress Catalog Card Number: 48-3076

PRINTED IN THE UNITED STATES OF AMERICA BY CHICAGO NATURAL HISTORY MUSEUM PRESS 


\section{CONTENTS}

Families Included in Part VII, Number 1

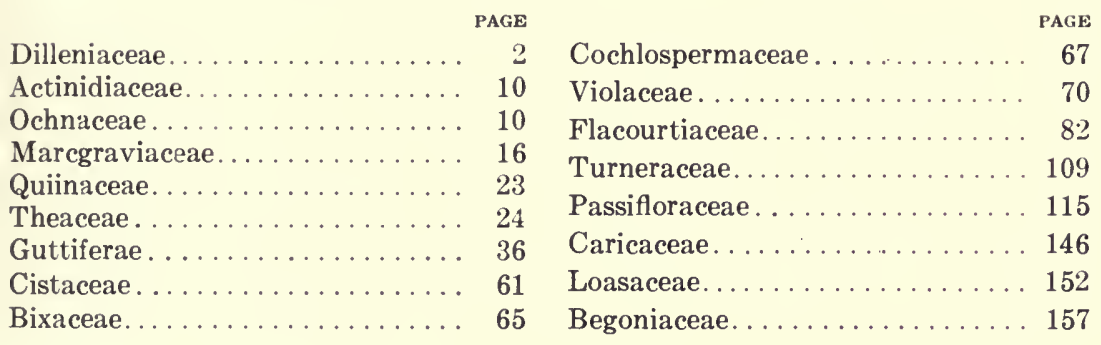





\section{LIST OF ILLUSTRATIONS}

\section{TEXT FIGURES}

PAGE

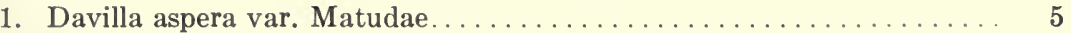

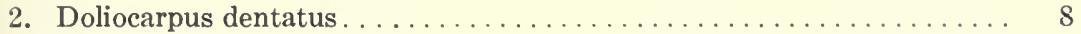

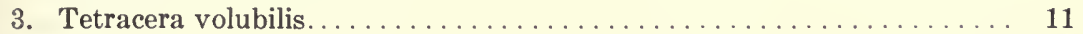

4. Ouratea lucens................................ 14

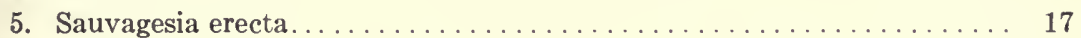

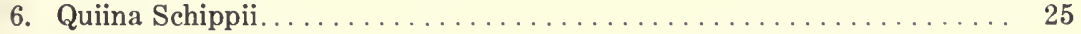

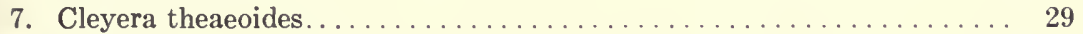

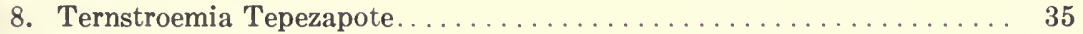

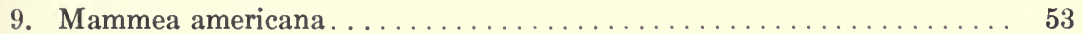

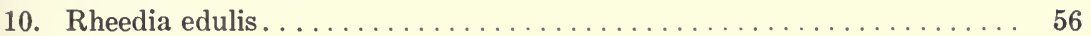

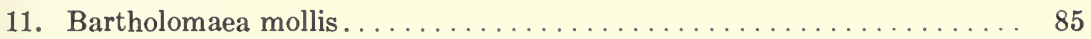

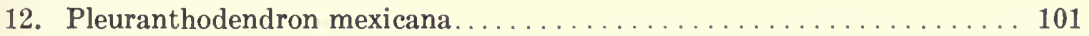

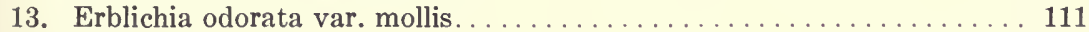

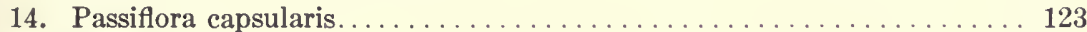

15. Passiflora edulis . . . . . . . . . . . . . . . . . . . . . 127

16. Passiflora quadrangularis . . . . . . . . . . . . . . . . . 142

17. Carica Papaya ................................. 149

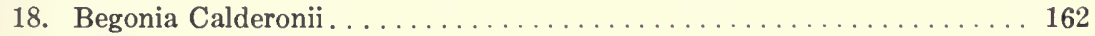

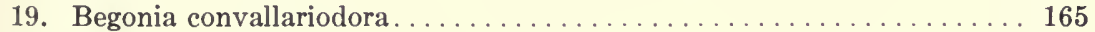

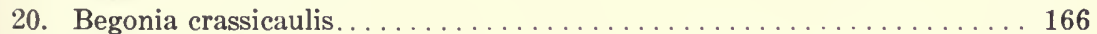

21. Begonia Franconis. . . . . . . . . . . . . . . . . . . . . 167

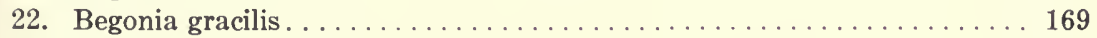

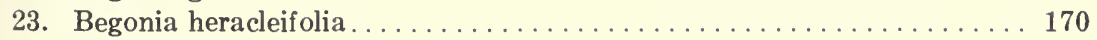

24. Begonia Heydei. . . . . . . . . . . . . . . . . . . . . . 172

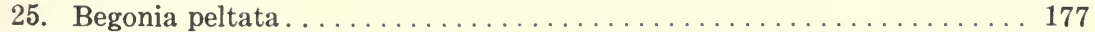

26. Begonia Popenoei. . . . . . . . . . . . . . . . . . . . . . . . . . . . . . 179

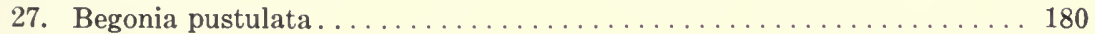

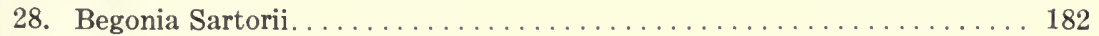

29. Begonia trichosepala ........................ 184 



\section{Flora of Guatemala}

\section{PARIETALES}

The group of families in part VII, number 1 of the Flora of Guatemala is a large order divided by Engler and Diels into 31 families. More than half (17) of these families are represented in Guatemala. Several are common in our flora, and many are not well understood. The Guttiferae and the Flacourtiaceae are perhaps the most difficult, and the generic entities in both families need careful study. Passiflora is the largest genus of this order in our flora.

Plants of the Parietales are most variable and perhaps the grouping is unnatural, but usually they may be characterized by a biseriate perianth in which the sepals and the petals may be distinguished one from the other, or in some genera the petals may be lacking (especially in Flacourtiaceae) or the perianth of tepals (Begoniaceae); the perianth is often pentamerous, but in many genera of the order it is not (2-10-merous); the petals and the calyx lobes may be imbricate (usually) or valvate; the stamens may be as many as the petals (or sepals) or often much more numerous; the ovary is most often of 3 carpels and unilocular, with parietal placentation (axile sometimes in Ochnaceae) and many or numerous ovules; it is most often superior but in the Loasaceae and Begoniaceae it is inferior, and it is partly inferior in some Flacourtiaceae and Theaceae. Unisexual flowers are not uncommon in the order.

The Parietales are a grouping for convenience rather than a phylogenetic one. It may be expected that some of the families will be removed to other orders and perhaps new orders established for some of these families.

The genus Saurauia, in this flora, has been separated as the Saurauiaceae and will be found in the last pages of the preceding part of the flora. The genus has been most often included in the Dilleniaceae; but it has also been placed in the Actinidiaceae, which would seem to be a reasonably satisfactory disposition of it. 


\section{DILLENIACEAE}

Trees or shrubs, often scandent, the pubescence usually harsh; leaves alternate, entire or dentate, usually with numerous parallel lateral nerves; stipules none, or winglike and adnate to the petiole, commonly deciduous; flowers small or mediumsized, perfect or polygamous; sepals 4-6, strongly imbricate, persistent; petals 5-6 or fewer, imbricate, often crumpled in bud, generally deciduous or caducous, usually thin and delicate; stamens numerous, rarely definite, hypogynous, free or variously united into bundles at the base, commonly persistent; anther cells opening by lateral slits or apical pores; carpels free, rarely only 1 ; ovules 1 or more in each carpel, erect from the base or from the inner angle of the carpel; styles free; fruiting carpels dehiscent or baccate, the seeds usually with a cristate or laciniate aril; endosperm copious, carnose, the embryo minute.

Eleven genera, in the tropics of both hemispheres. Only the following are known in North America.

Sepals dissimilar, the 2 inner ones erect, valvate and enclosing the fruit; petals bright yellow; flowers mostly in terminal panicles; plants scandent. . Davilla Sepals all alike, spreading or ascending, not enclosing the fruit; petals usually white, not bright yellow.

Flowers chiefly in terminal panicles; carpels 1-5, distinct, glabrous; woody

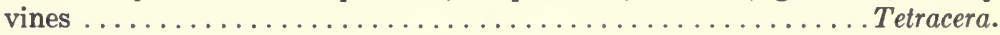

Flowers axillary or lateral, in panicles or umbels; carpels 1, or 2 and united.

Carpel of the fruit 1 , or didymous; plants scandent......... Doliocarpus. Carpels of the fruit 2 ; plants erect................. Curatella.

\section{GURATELLA L. Sandpaper tree}

Small trees with very harsh, rough pubescence; leaves penninerved; flowers white, small, crowded in small, lateral, sessile panicles; sepals 4-5, spreading; petals 4-5; anthers oblong, the cells almost parallel; carpels 2, globose at maturity, dorsally dehiscent or fleshy and indehiscent, coherent at the base; ovules geminate, erect; seeds almost completely surrounded by a membranaceous aril.

Species 2, one West Indian.

Curatella americana L. Syst. Nat. ed. 10.1079.1759. C. americana var. pentagyna Donn.-Sm. Bot. Gaz. 46: 109. 1908 (type from Salamá, Baja Verapaz, W. A. Kellerman 6499). Chaparro; saha (Petén, fide Lundell); lengua de vaca.

Chiefly on dry open or brushy hillsides, often on pine-clad slopes, 1,200 meters or less; Petén; Alta Verapaz; Baja Verapaz; Izabal; Chiquimula. Western Mexico; British Honduras to El Salvador and Panama. Cuba; South America.

Mostly 6 meters high or less, the trunk short and thick, the crown spreading, the bark with large thin grayish scales that fall easily, the inner bark reddish or light brown; leaves short-petiolate or sessile, oval to elliptic-ovate, mostly $12-30$ $\mathrm{cm}$. long, rounded or very obtuse at the apex, often emarginate, abruptly cuneate, 
decurrent at the base, thick, sinuate or irregularly shallow-denticulate, very scabrous on both surfaces; ill-scented; flowers white or pinkish, long-pedicellate, in short sessile lateral panicles, mostly on old wood; petals 5-6 mm. long, glabrous; mature carpels 6-7 mm. long, densely hirsute; seeds black.

Called "yaha" in British Honduras; "caticón" (Tabasco); "hojamán" (Oaxaca); "malcajaco," "lengua de vaca" (El Salvador). Var. pentagyna is a presumably abnormal form with 5 rather than the usual 2 carpels of the ovary and fruit. According to Seler, the seeds are or were used in Oaxaca for flavoring chocolate. The rough leaves contain much silica and are used commonly in tropical America as a substitute for sandpaper, to polish articles of wood or metal. The bark is utilized in some regions for tanning skins. The wood is brown or reddish brown, variegated by the prominent rays, rather hard and heavy, with a specific gravity of about 0.77 ; the grain is interwoven, and the texture is coarse; the wood is hard to cut and to plane and it is durable. It is employed in various regions for fuel, charcoal, fence posts, or even cabinet work, and in Central America particularly for making saddle frames. In Guatemala the tree seems to be most plentiful on the pine-clad hillsides of Izabal and Baja Verapaz, where often it is associated with Byrsonima crassifolia. This association, without the pines, is characteristic of many subarid regions of the whole Pacific coast from El Salvador to Panama, and in South America.

\section{DAVILLA Vandelli}

Scandent shrubs; leaves coriaceous, usually very rough, without stipules; flowers paniculate, bright yellow, the panicles mostly small, terminal or arising in the upper leaf axils; sepals 5, very unequal, the 2 interior ones larger, very concave, accrescent, becoming coriaceous, enclosing the fruit and simulating a globose capsule; petals 1-6; filaments thickened at the apex, the anthers short, their cells divergent; carpels of the ovary 1-3, the ovules geminate, erect; mature carpels indehiscent or rupturing irregularly; seeds almost completely enclosed in the aril.

Species about 30, mostly in Brazil. Only the following are found in Central America.

Larger sepals hirtellous; leaves densely soft-pilose beneath........ . Kunthii. Larger sepals glabrous; leaves glabrate beneath, usually somewhat pilose along the nerves ......................... aspera var. Matudae.

Davilla aspera (Aubl.) Ben. var. Matudae (Lundell) L. Wms. Fieldiana, Bot. 29: 350. 1961. Davilla Matudae Lundell, Phytologia 1: 371. 1940 (type from near Palenque, Chis., Matuda 3647a). Chaparro. 
Moist or wet thickets or forest at or little above sea level, sometimes in mangrove swamps; Izabal. Mexico through Central America, except El Salvador. Figure 1.

A small to large woody vine or liana, the bark exfoliating, ferruginous, the branches glabrous or sparsely appressed-hirsute; leaves petiolate, coriaceous, mostly oval to rounded-obovate, sometimes oblong-elliptic, 5-16 cm. long, 2-6.5 $\mathrm{cm}$. wide, rounded to acute at the apex, rounded to acute at the base and often abruptly decurrent, entire or undulate, rough or smooth above and glabrous or nearly so, rough or smooth beneath, usually with at least a few stiff hairs along the costa, often papillose; panicles small or large, $12 \mathrm{~cm}$. long or less, usually manyflowered; outer sepals sericeous, the inner ones larger, glabrous or nearly so, in fruit 5-8 $\mathrm{mm}$. long; petals bright yellow, fugacious; carpel 1-seeded, the seed $2.5 \mathrm{~mm}$. long.

This variety has been confused commonly with Davilla Sagraeana A. Rich. and Davilla rugosa Poir., both of which may be synonyms of $D$. aspera var. aspera. It has also been confused with species of Tetracera. There is considerable variation in the Central American specimens referred to this variety. Called bejuco quemador and bejuco corralero in adjacent Mexico.

Davilla Kunthii St. Hil. Pl. Usuel. Bras. 6. 1824-28. Bejuco chaparrón; chaparro; sajab (Petén, Maya, fide Lundell).

Moist or wet forest, often in hilly pine forest, 350-450 meters or less; Petén; Alta Verapaz; Izabal; Huehuetenango. Southern Mexico; British Honduras to Panama. South America.

A small or large, woody vine, the branches densely hirsute with spreading hairs, the bark exfoliating; leaves petiolate, coriaceous, oblong-elliptic to suborbicular, 6-18 $\mathrm{cm}$. long, broadly rounded to subacute at the apex, rounded to acute at the base, scabrous above and very rough to the touch, of ten lustrous, the nerves impressed, the surface rugose, densely soft-pilose beneath, the lateral nerves very conspicuous and elevated; panicles small or large, many-flowered; sepals densely pilose or hirsute, the inner ones becoming 7-10 mm. long; carpel 1 .

Called "chaparro" in British Honduras and "bejuco de tachicón" in Tabasco; "lija" (Oaxaca). The heavy, very rough leaves contain much silica and often are used like sandpaper and for cleaning pots and dishes.

\section{DOLIOCARPUS Roland}

Woody vines, glabrous or pubescent, usually not or but slightly scabrous; leaves dentate to subentire; panicles few- to many-flowered, or the flowers solitary or fasciculate in the leaf axils or at defoliated nodes or lateral, white or yellowish; sepals 3 or 5 , equal to subequal, spreading; petals usually $3-4$, sometimes 2 ; filaments thickened at the apex, the anthers short, the cells almost parallel or slightly 


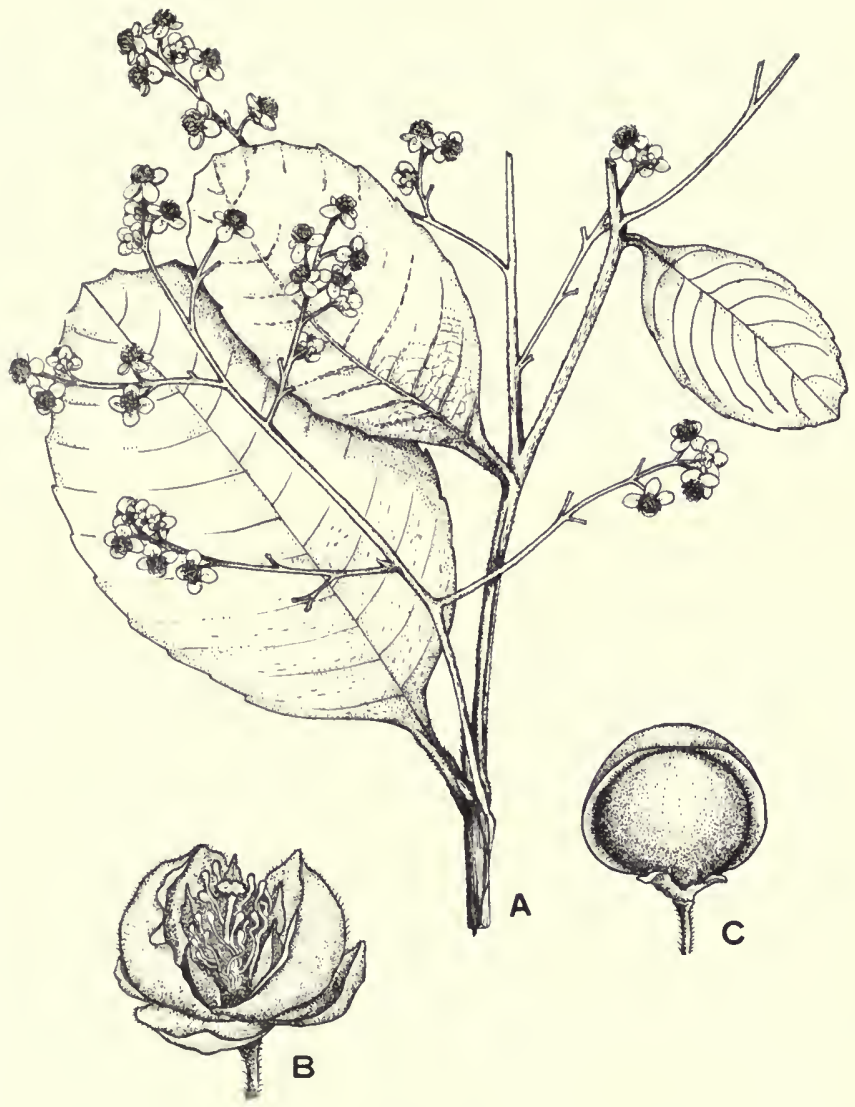

FIG. 1. Davilla aspera var. Matudae. A, Branch; $\times 1 / 2 . \quad$ B, Flower; $\times 5$. $\mathrm{C}$, Flower in fruiting condition with two large sepals enclosing fruit; $\times 5$. 
divergent; carpels of the globose ovary 1 or 2 , the ovules geminate, erect; fruit at maturity baccate and indehiscent or coriaceous and 2-valvate or didymous; seeds surrounded by a membranaceous or fleshy aril.

About 25 species in tropical America, chiefly in Brazil. Four additional species are known from Central America. Possibly one additional species in Guatemala, as yet undescribed.

Leaves acute to acuminate at apex, elliptic-oblong to oblanceolate-oblong, entire to coarsely dentate; flowers fasciculate; pedicels $10-15 \mathrm{~mm}$. long; style 1 .

D. dentatus.

Leaves rounded at apex, suborbicular-obovate to obovate-oblong, entire or subundulate; flowers paniculate; pedicels $2-6 \mathrm{~mm}$. long; styles $2 \ldots . . D$. coriaceus.

Doliocarpus coriaceus (Mart. \& Zucc.) Gilg, in Engl. \& Prantl, Nat. Pflanzenfam. 3, Abt. 6: 114. 1893. Pinzona coriaceus Mart. \& Zucc. Abh. Akad. Muench. 1: 371. 1837. D. nicaraguensis Standl. Field Mus. Bot. 4: 233. 1929 (type from region of Braggman's Bluff, Nicaragua, Englesing 277). D. belizensis Lundell, Field \& Lab. 13: 6. 1945 (type from British Honduras, Gentle 4389). Water tietie (British Honduras).

Wet lowland forest, British Honduras; Nicaragua; Colombia; British Guiana; Brazil.

A small or large woody vine, the branches glabrous or strigillose, the older ones with exfoliating bark; leaves petiolate, the petiole thickened below, narrowly margined, $1.3-2 \mathrm{~cm}$. long, 2-2.5 $\mathrm{mm}$. wide, the blade coriaceous, obovate-elliptic to broadly or suborbicular-obovate, $7-14 \mathrm{~cm}$. long, $4-10 \mathrm{~cm}$. wide, rounded at apex and short-apiculate, obtuse, rounded, or cuneate at the decurrent base, entire or subundulate, mostly glabrous on both sides, midrib above minutely scabridulous to glabrate, below glabrous to sparsely puberulous, lateral nerves slender, prominent, 6-10 pairs, elevated beneath, glabrous or minutely hispidulous on the upper surface, glabrous to minutely puberulous on the lower surface, veins prominently finely reticulate, especially below; flowers paniculate, the panicles axillary, sessile, contracted, closely and many-flowered in early anthesis, becoming more lax and more elongated in fruiting stage, the panicles 1-3.5 $\mathrm{cm}$. long; peduncles $6-10 \mathrm{~mm}$. long, puberulous; bracts ovate to lance-oblong, strigillose without; pedicels $2-6 \mathrm{~mm}$. long, slender, puberulous; flowers whitish or greenish, fragrant; sepals usually 3 , suborbicular to broadly obovate-oblong, 3-3.8 $\mathrm{mm}$. long, 2-3 mm. wide, rounded at the apex, persistent, reflexed, ciliolate; petals usually 2 , obovate-oblong, $4-4.5 \mathrm{~mm}$. long, $2.5-3 \mathrm{~mm}$. wide, rounded at apex; stamens numerous, shorter than the sepals; styles $2,1.25-2 \mathrm{~mm}$. long; fruit didymous, $4-5 \mathrm{~mm}$. high, $4-7 \mathrm{~mm}$. wide, the locules subglobose, connate above, smooth, glabrous.

This species belongs to the section Pinzona of the genus, characterized by having two styles instead of one. Study of type material of $D$. belizensis and $D$. nicaraguensis leaves no doubt that they are conspecific with the South American $D$. coriaceus. 
Doliocarpus dentatus (Aubl.) Standl. Journ. Wash. Acad. Sci. 15: 286. 1925. Tigarea dentata Aubl. Pl. Guian. 920, pl. 351. 1775. D. oaxacanus Szysz. Diss. Math.-Nat. Acad. Litt. Cracov. 27: 139. 1894 (type from Oaxaca).

Chiefly in wet lowland forest; 200 meters or less; Petén; Alta Verapaz; Izabal; Huehuetenango. Mexico; British Honduras, along the Atlantic coast to Panama; northern South America. Figure 2.

A small or large, woody vine, the branches glabrous or nearly so, the older ones with dark ferruginous, exfoliating bark; leaves petiolate, coriaceous, ellipticoblong to oblong or oblanceolate-oblong, mostly 9-21 cm. long, acute or acuminate or abruptly acute, narrowly or broadly cuneate at the base, coarsely dentate to almost entire, glabrous above and smooth to the touch, dull, paler beneath and brownish, often lustrous, at first short-pilose along the costa and veins but in age glabrate, usually barbate in the nerve axils, the lateral nerves slender, prominent, about 10 pairs; flowers fasciculate on the older branches, slender-pedicellate, the pedicels mostly $1-1.5 \mathrm{~cm}$. long, puberulent; flowers $3-4 \mathrm{~mm}$. long, whitish, the sepals minutely appressed-pilose; fruit globose, 8-12 $\mathrm{mm}$. in diameter, red.

This has been reported from Guatemala under the name $D$. Rolandri Gmel.

\section{TETRACERA L.}

Scandent shrubs, the pubescence usually rough; leaves coriaceous, conspicuously nerved; flowers paniculate, the panicles terminal or from the upper leaf axils, many-flowered, lax or dense; sepals 4-6, spreading; petals 4-6 or sometimes fewer; filaments dilated at the apex, the anthers small, their cells somewhat divergent; carpels of the ovary 1-5, acuminate, the ovules numerous, biseriate; mature carpels coriaceous, lustrous, 2-valvate or dehiscent along one suture; seeds 1-5, surrounded by a lacerate aril.

About thirty species in the tropics of both hemispheres. No other species are known from Central America.

Sepals sericeous within; carpels of the fruit 2-5.

Leaves scabrous beneath, very rough to the touch .......... volubilis.

Leaves pilose beneath, not rough to the touch . . . . . . . . . mollis. Sepals glabrous within; carpels of the fruit 1, or $2-4$.

Carpels of the fruit 1, dark brown; leaves oblong to obovate, mostly closely dentate or serrate.................................. sessilifiora.

Carpels of the fruit 2-4, tawny; leaves broadly ovate-elliptic to broadly ovateoblong, entire to sparsely denticulate............ . jamaicensis.

Tetracera jamaicensis DC. Syst. Nat. 1: 399. 1818. T. belizensis Lundell, Contr. Univ. Mich. Herb. 6: 44.1941 (type from British Honduras, Gentle 2794). Chaparo.

Thickets or forests. Izabal. British Honduras; Honduras; Nicaragua; Panama; Jamaica. 


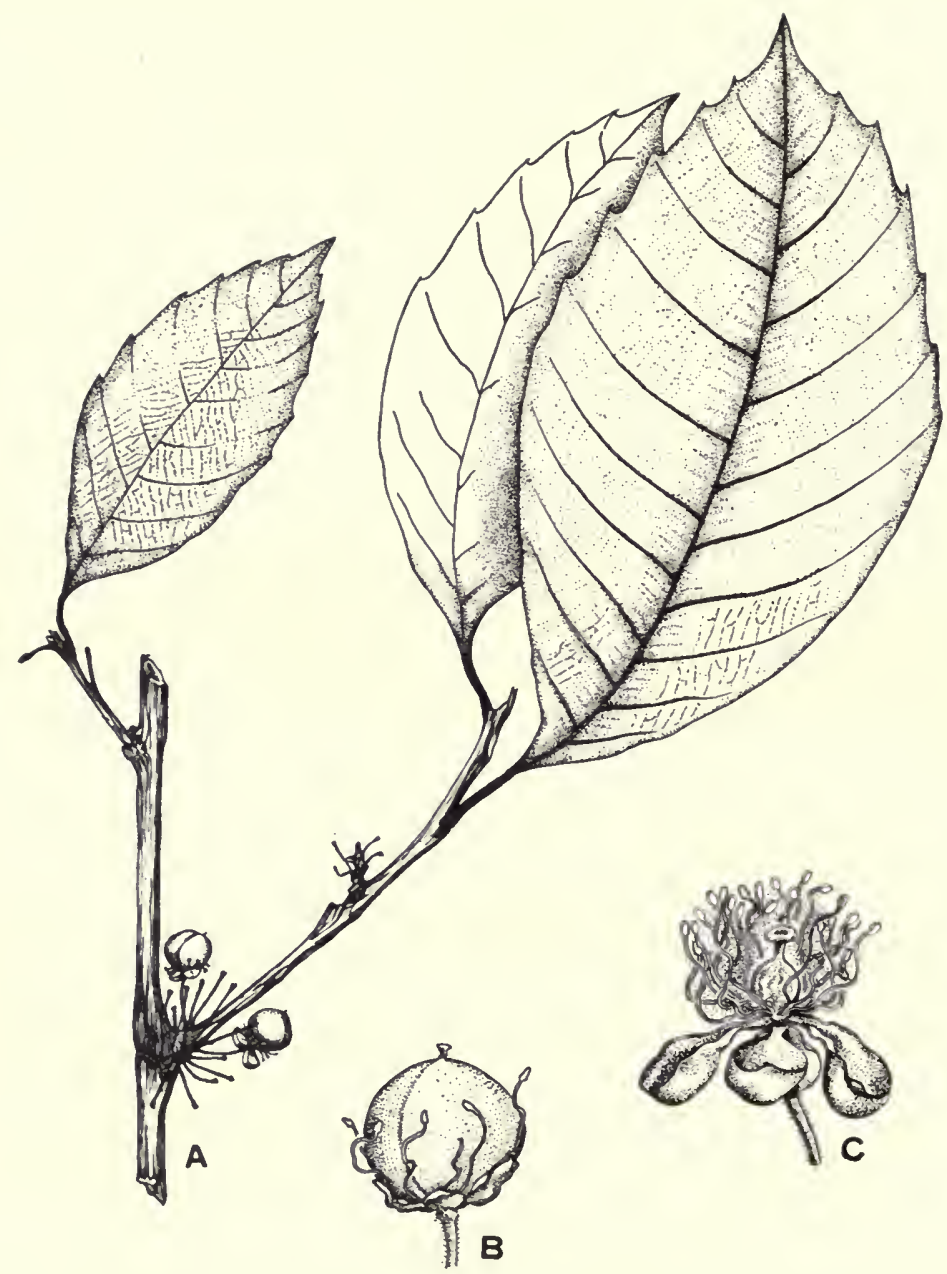

FIG. 2. Doliocarpus dentatus. A, Fruiting branch; $\times 1 / 2 . \quad$ B, Fruit; $\times 21 / 2$. C, Flower; $\times 5$. 
Woody vine, the branches at first densely and minutely stellate-scabrid intermixed with scattered, straight, appressed hairs, finally becoming scabrous and brownish; leaves long-petiolate, the petioles $1.2-2.5 \mathrm{~cm}$. long, sparingly strigose and minutely stellate-scabrid, slightly winged above; leaf blade broadly ovateelliptic to broadly ovate, 7-17 cm. long, 5.5-10 cm. wide, rounded and short apiculate at apex, rounded at base, mostly entire or subentire or with a few short teeth near apex, both surfaces finely scabrous, the costa bearing a few straight hairs, these appressed on lower surface, spreading above, costa and veins slightly impressed above, prominent below, the main lateral nerves 11-13, prominently reticulate beneath; panicles dense, dioecious; staminate flowers with slender stellate-scabrid pedicels to $8 \mathrm{~mm}$. long; sepals subequal, suborbicular, 5-7 mm. long, ciliolate, glabrous within, minutely scabrous without with the outer bearing a few simple appressed hairs; petals obovate, to $10 \mathrm{~mm}$. long, glabrous; stamens about $5 \mathrm{~mm}$. long; carpels of the fruit 2-4, tawny, short-rostrate, 10-15 mm. long, glabrous.

Tetracera mollis Standl. Field Mus. Bot. 8: 25. 1930. Saha (Petén, Maya, fide Lundell).

Wet thickets, 300 meters or less, Petén; Izabal. British Honduras, the type from Honey Camp, Orange Walk, Lundell 47.

A large or small vine, the bark dark ferruginous, exfoliating, the branches densely pilose with intermixed, simple and stellate hairs; leaves petiolate, broadly oblong or elliptic-oblong, 8-14 cm. long, 4-7 cm. wide, rounded, subacute, or abruptly acuminate at the apex, obtuse or rounded at the base and often abruptly decurrent, serrulate or repand-dentate, at least toward the apex, very scabrous above, densely velutinous-pilose beneath with simple and stellate hairs, the lateral nerves about 13 pairs, prominent; panicles small or rather large, shorter or longer than the leaves; sepals obovate, 7-9 $\mathrm{mm}$. long, obtuse, sericeous on both surfaces; carpels of the ovary 3 , acuminate, lustrous, $1 \mathrm{~cm}$. long, sparsely appressed-pilose; seeds solitary; flowers yellowish white.

Tetracera sessiliflora Triana \& Planch. Ann. Sci. Nat. IV. 17: 21. 1862 .

Reported by Hemsley from Guatemala; western and southern Mexico; British Honduras; Costa Rica; Panama; Colombia.

A large vine, the young branches hirsute and stellate-pubescent; leaves shortpetiolate, oblong to obovate, 6-20 cm. long, rounded or obtuse at the apex, often abruptly short-pointed, obtuse to rounded at the base and abruptly decurrent, remotely dentate to subentire, usually very scabrous on both surfaces, sometimes sparsely pilose beneath; panicles mostly large and many-flowered, the flowers white; sepals orbicular, densely pubescent; carpel of the fruit only 1 , very lustrous, 6-8 mm. long.

The names "sumac" (Maya) and "berisa" are reported from British Honduras. The flowers are sweet-scented. The stems, as in other species, are employed as a substitute for cordage, especially 
for binding the framework of huts. The rough leaves are sometimes used like sandpaper.

Tetracera volubilis L. Sp. Pl. 533. 1753. Chaparro tietie. Bejuco de agua; sahaac (Petén, Maya, fide Lundell); cachicón (Petén, fide Lundell).

Moist or dry thickets, sometimes in open forest, 360 meters or less; Petén; Alta Verapaz; Santa Rosa; Escuintla; Suchitepéquez; Retalhuleu; San Marcos. Southern Mexico; British Honduras to El Salvador and Panama; West Indies; South America. Figure 3.

A small or large vine, the branches brownish, with exfoliating bark, the young branches more or less hirsute, glabrate in age; leaves short-petiolate, obovateoblong to obovate, $7-18 \mathrm{~cm}$. long, rounded or abruptly short-pointed at the apex, cuneate at the base and often decurrent, serrulate or subentire or often coarsely dentate, very scabrous on both surfaces, usually appressed-hirsute beneath on the nerves; panicles often very large and dense; sepals orbicular, unequal, 3-5 $\mathrm{mm}$. long, sericeous within, scabrous outside, ciliate; carpels of the fruit $3-5$, shortrostrate, 7-10 $\mathrm{mm}$. long, sparsely pilose at the apex.

Called "lengua de vaca" in El Salvador. The vine is very common in thickets and dry forest of the Pacific lowlands. It is one of the more familiar water vines of Central America, the larger stems, when cut, yielding a large amount of clear sap that may be drunk in place of water when the sources of this fluid are not available, as so often happens during the dry months in the lowlands of Central America.

\section{ACTINIDIAGEAE}

The genus Saurauia would have been found in this place had the system proposed by Engler and Gilg been strictly adhered to. The account of the genus will be found under Saurauiaceae, vol. 24, pt. 6: 428-438. 1949, of this Flora.

\section{OGHNAGEAE}

Trees, shrubs, or herbs, mostly glabrous; leaves simple, alternate, coriaceous or membranaceous, usually dentate, often with fine close venation; stipules entire or pectinate; flowers small or large, yellow, pink, or white, solitary in the leaf axils or in terminal or axillary racemes or panicles; sepals 5; petals 5; petaloid staminodia often present, 5 , distinct, opposite the petals and separated from them by a whorl of sterile filaments; fertile stamens 5 or 10; ovary 3-celled at the base, or 1-celled and 5-6-lobate with each of the lobes 1-celled; fruit capsular or drupaceous.

About 17 genera, widely distributed in tropical regions. One other genus, Cespedesia, a large tree with showy yellow flowers, is represented in southern Central America. 


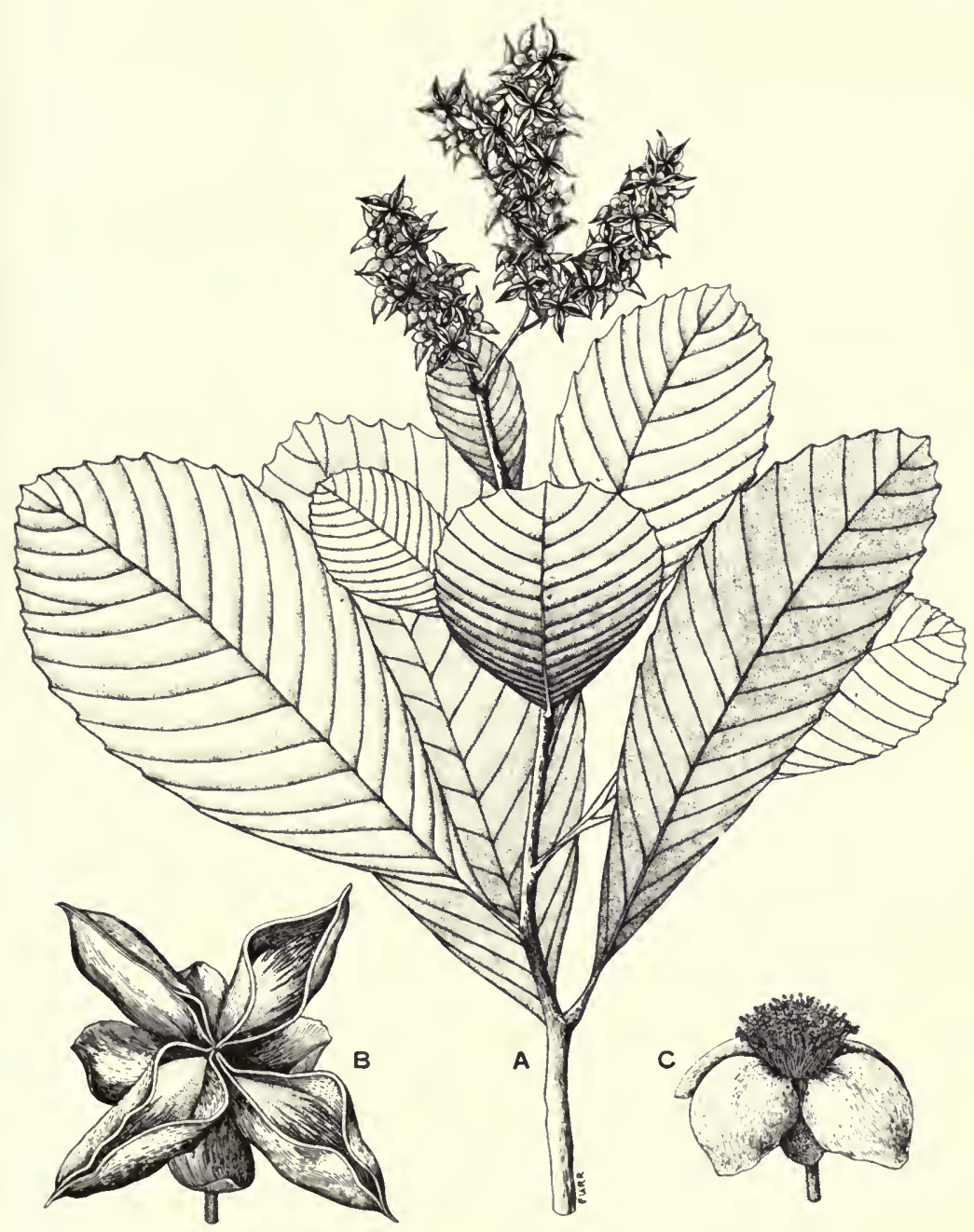

FIG. 3. Tetracera volubilis. A, Fruiting branch; $\times 1 / 2$. B, Flower, showing mature carpels; $\times 4$. C, Flower; $\times 4$. 
Plants shrubs or trees; petals yellow; stamens 10 ; fruit drupaceous. . . . . . Ouratea. Plants low herbs; petals pink or white; fertile stamens 5; fruit capsular.

Sauvagesia.

\section{OURATEA Aublet}

References: L. A. M. Riley, The Mexican and Central American species of Ouratea, Kew Bull. 101-114. 1924. John D. Dwyer, The taxonomy of the Mexican, Central American, and West Indian species of Ouratea, Lloydia 7: 121-145. 1944.

Glabrous shrubs or small trees; leaves alternate, persistent, coriaceous, lustrous, serrate, finely and closely veined; stipules free in American species; flowers showy, yellow, in terminal or terminal and axillary panicles or racemes, bracteate, the pedicels articulate at the base; sepals 5, usually colored, persistent or deciduous, imbricate; petals 5 , somewhat longer than the sepals, obovate, unguiculate, imbricate; torus thick, elevated to form a gynophore, lobate; stamens 10 , inserted on the base of the torus, erect, connivent, the filaments very short; anthers rugose, dehiscent by pores; ovary 5-6-parted, the lobes obliquely inserted on the torus; styles connate, the stigma simple; ovules solitary in each cell, ascending from the base; fruits drupaceous, 5 or by abortion fewer, sessile on the enlarged torus; seed erect, the testa membranaceous; cotyledons carnose, plano-convex; radicle very short, descending to the hilum.

Species described more than 100, mostly from the American tropics with a few from Africa and Asia.

The Central American species of Ouratea have "suffered" two revisions in relatively recent years but are still in need of a revision that takes into account the South American as well as the North American species. Some of the names in this treatment will possibly be changed when such a revision is made.

Leaves mostly $30-45 \mathrm{~cm}$. long, usually clustered at the ends of the branches.

Leaves oblong, the veins not evident beneath; panicles half as long as the leaves.

O. lucens var. podogyna.

Leaves narrowly oblanceolate-oblong, the veins conspicuous beneath; panicles equaling the leaves.......................... Tuerckheimii.

Leaves smaller, mostly 6-18 cm. long, scattered along the branches.

Nerves of the leaves impressed on both surfaces............... nitida.

Nerves of the leaves not impressed...................... lucens.

Ouratea lucens (HBK.) Engler in Mart. Fl. Bras. 12, pt. 2: 350. 1876; L. Wms. Fieldiana, Bot. 29: 352. 1961. X canlol, xcolol (British Honduras). Gomphia lucens HBK. Nov. Gen. \& Sp. 7: 219. 1825 (type from Colombia, Humboldt 1445). Ouratea guatemalensis Engler, l.c. 345 (type from Guatemala, Friedrichsthal 780). O. Peckii Riley, Kew Bull. 1924: 109. 1924 (type from British Honduras, Peck 
617). O. stenobotrys Riley, l.c. (type from British Honduras, Hooper). O. Wrightii (Van Tiegh.) Riley, l.c. 110 (type from Nicaragua).

Moist and wet thickets, often in second growth, at 700 meters or less; Petén; Alta Verapaz; Izabal; Esquintla; Retalhuleu. Mexico through Central America to Colombia. Figure 4.

A glabrous shrub or small tree of 1-6 meters, the branches slender, often flexuous; leaves coriaceous, on petioles $3-4 \mathrm{~mm}$. long, lance-oblong or narrowly oblanceolate, mostly $10-18 \mathrm{~cm}$. long and $3-5.5 \mathrm{~cm}$. wide, acuminate, rounded to acute at the base, serrate toward the apex or throughout, the veins conspicuous, not impressed; stipules triangular-acuminate, $8-9 \mathrm{~mm}$. long, denticulate, striate; panicles usually racemiform, few-many-flowered, dense or lax; pedicels $5-10 \mathrm{~mm}$. long or in age longer; sepals ovate-lanceolate, the outer ones about $7 \mathrm{~mm}$. long, obtuse; petals obovate, $6-9 \mathrm{~mm}$. long; anthers obclavate, about $5 \mathrm{~mm}$. long; drupes 1-5, ellipsoid, black, juicy; torus $5 \mathrm{~mm}$. in diameter, bright red.

Called "coyolillo" and "naranjillo" in El Salvador. Because of its bright yellow flowers, this is a rather showy plant, like other members of the genus. The young leaves are tinged with bronze. The base of the trunk is often enlarged with thick knobby buttresses of distinctive form and appearance. The material referred here was distributed by Dwyer among five species based upon characters that vary too much to serve for specific distinction in the case of these Central American plants.

Ouratea lucens var. podogyna (Donn.-Sm.) L. Wms. Fieldiana, Bot. 29: 352. 1961. O. podogyna Donn.-Sm. Bot. Gaz. 18: 2. 1893 (type from Guatemala, von Türckheim 1034). O. insulae Riley, Kew Bull. 1924: 106. 1924 (type from Honduras, Gaumer 89). O. pyramidalis Riley, l.c. 107 (type from Mexico, Rovirosa 495).

Alta Verapaz; Izabal; Petén. Mexico, British Honduras and Honduras, possibly Panama.

Similar to the species but with a more floriferous, larger and more spreading panicle; the leaves larger and more prominently serrate.

Ouratea nitida (Swartz) Engler in Mart. Fl. Bras. 12, pt. 2: 310. 1876. Ochna nitida Swartz, Prodr. Veg. Ind. Occ. 67. 1788.

Wet forest, at little above sea level; Petén; Izabal. Yucatan peninsula of Mexico; British Honduras; Honduras; Nicaragua; Panama; Cuba and Jamaica; northern South America.

A glabrous shrub or a small tree, 6 meters high or less, the trunk as much as $10 \mathrm{~cm}$. in diameter; leaves on very short petioles, coriaceous, elliptic to ellipticoval, 6-13 cm. long, acute or rather abruptly acuminate, obtuse or rounded at the base, serrulate, the nerves and veins impressed on both surfaces; flowers bright 


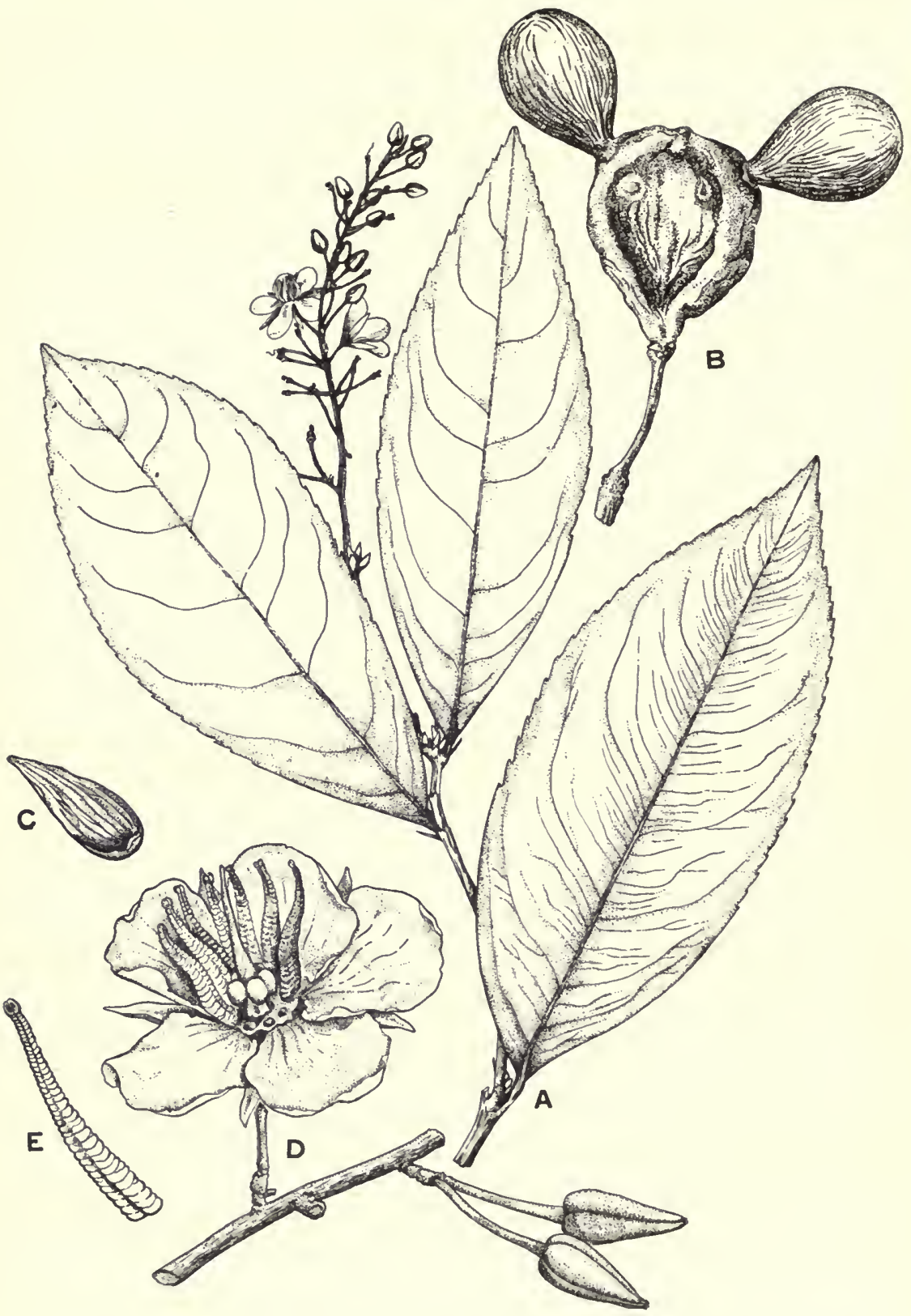

Fig. 4. Ouratea lucens. A, Flowering branch; $\times 1 / 2 . \quad B$, Torus, showing two persistent drupes; $\times 21 / 2$. C, Sepal; $\times 21 / 2$. D, Portion of inflorescence, showing partially dissected flower (3 stamens removed) and buds; $\times 2 \frac{1}{2}$. E, Stamen, showing apical pores; $\times 5$. 
yellow, in pyramidal panicles, these often much exceeding the leaves; pedicels 5-7 mm. long, or in fruit longer; sepals about $7 \mathrm{~mm}$. long; petals slightly longer than the sepals; drupes 1-5, dark blue at maturity, globose, $7 \mathrm{~mm}$. long; seed large, globose.

Called "bastard blossom berries" in British Honduras.

Ouratea Tuerckheimii Donn.-Sm. Bot. Gaz. 33: 249, t. 10. 1902. Yepú (Alta Verapaz).

Wet mixed forest, 350 meters or less; Petén; Alta Verapaz (type from Cubilqüitz, Tuerckheim 7829); Panama.

A glabrous shrub or small tree 3-6 meters high; leaves mostly in clusters of 3-4 at the ends of the branches, on petioles 6-12 $\mathrm{mm}$. long, oblanceolate-oblong, coriaceous, $35-45 \mathrm{~cm}$. long, 8-11 cm. wide, acuminate, obtuse or rounded at the base, deep green above, pale green beneath, acutely serrate, the nerves and veins prominent beneath; panicles much branched, almost as long as the leaves, the pedicels 10-13 mm. long; sepals linear-oblong, $1 \mathrm{~cm}$. long; petals spatulate-obovate, 11-12 mm. long; anthers $9 \mathrm{~mm}$. long; drupes globose, $9 \mathrm{~mm}$. in diameter.

The flowers are said to have the odor of lily of the valley (Convallaria). This species is closely allied to O. crassinervia Engler.

\section{SAUVAGESIA L.}

Glabrous, usually small and wiry, erect, annual or perennial herbs; leaves small, membranaceous, alternate, entire or serrulate; stipules pectinate-ciliate; flowers very small, axillary or in terminal racemes, white or pink; sepals subequal; petals equal, convolute; outer staminodia numerous or 5 and alternating with the petals, the 5 interior staminodia petaloid, opposite the petals and connivent about the stamens and ovary; filaments of the fertile stamens very short, alternate with the inner staminodia; anthers linear, the cells laterally dehiscent; ovary with 3 placentae, the style simple, the stigma obtuse; fruit a small capsule, septicidally 3-valvate; seeds numerous, small, the testa crustaceous, usually favose-scrobiculate; endosperm carnose, the radicle longer than the cotyledons.

About 18 species, mostly American, a few in the Old World tropics. One additional species is known from Panama.

Lobes of the stipules filiform, bearing small glands at about the middle; plants mostly $10 \mathrm{~cm}$. high or less ...................... pulchella. Lobes of the stipules without glands.

Sepals 2-2.5 mm. long; plants mostly $10 \mathrm{~cm}$. high or less........ tenella. Sepals $5 \mathrm{~mm}$. long; plants mostly $30 \mathrm{~cm}$. high or taller.......... erecta.

Sauvagesia erecta L. Sp. Pl. 203. 1753. Yerba del judio (Izabal, fide Blake).

Usually in moist or wet soil of savannas, open grassy banks, moist thickets, or pine forest, 1,450 meters or less; Alta Verapaz; 


\section{Izabal; Huehuetenango. Southern Mexico; British Honduras to} Panama; West Indies; South America. Figure 5.

Plants erect, annual or probably at times perennial, the stems wiry, often red or brown, simple or sparsely branched, usually $20-40 \mathrm{~cm}$. high; leaves almost sessile, elliptic-lanceolate to oblong-lanceolate, usually $1-2 \mathrm{~cm}$. long, acute at each end, serrulate; stipules conspicuous, 3-6 $\mathrm{mm}$. long, pectinate-ciliate with very long, slender divisions; flowers axillary, the pedicels filiform, mostly shorter than the leaves; sepals lanceolate or ovate-lanceolate, $5 \mathrm{~mm}$. long, acuminate, mucronate; petals obovate, pink or almost white, 5-6 $\mathrm{mm}$. long; capsule slightly longer than the persistent sepals; seeds minute, ellipsoid, deeply pitted.

This and other species of Sauvagesia are characteristic plants of wet savannas and banks of creeks.

Sauvagesia pulchella Planch. in Seem. Bot. Voy. Herald 80 . 1852.

Grassy open pine or oak forest, 1,000-1,500 meters (to be expected also at much lower elevations); Chiquimula; Jalapa. El Salvador; Honduras; Costa Rica; Panama. South America.

Plants annual, erect, mostly $10 \mathrm{~cm}$. high or less, sometimes taller, simple or sparsely branched; leaves almost sessile, ovate-lanceolate or oblong-lanceolate, 10-12 mm. long; stipules $5 \mathrm{~mm}$. long, pectinate-ciliate, the divisions glandular and thickened at about the middle; flowers solitary or binate in the upper leaf axils, the pedicels about $5 \mathrm{~mm}$. long; sepals $2 \mathrm{~mm}$. long, the petals longer, pink; capsule $4 \mathrm{~mm}$. long, acute; seeds scrobiculate.

Sauvagesia tenella Lam. Ill. 2: 119. 1793.

Open, wet, usually grassy places at low elevations; reported by Hemsley from Barbasco, Bernoulli 947, probably in Zacapa.

Southern Mexico(?); British Honduras; Honduras; Costa Rica; Panama. South America.

Plants annual, usually simple and $10 \mathrm{~cm}$. high or less; leaves almost sessile, obovate-lanceolate or oblong-lanceolate, $5-10 \mathrm{~mm}$. long, acute, attenuate to the base, remotely glandular-denticulate; stipules $2-4 \mathrm{~mm}$. long, pectinate-ciliate, the divisions eglandular; flowers $1-3$ in the upper leaf axils, the pedicels $5-10 \mathrm{~mm}$. long; open flowers 7-9 mm. broad; sepals lanceolate, aristate-attenuate, subserrulate at the apex, white-marginate; petals white or pink, slightly longer than the sepals, obovate, obtuse; capsule ovoid, not exceeding the calyx; seeds minute, scrobiculate.

\section{MARCGRAVIACEAE}

Reference: E. Gilg \& E. Werdermann, Nat. Pflanzenfam. ed. 2, 21: 94-106. 1925. 


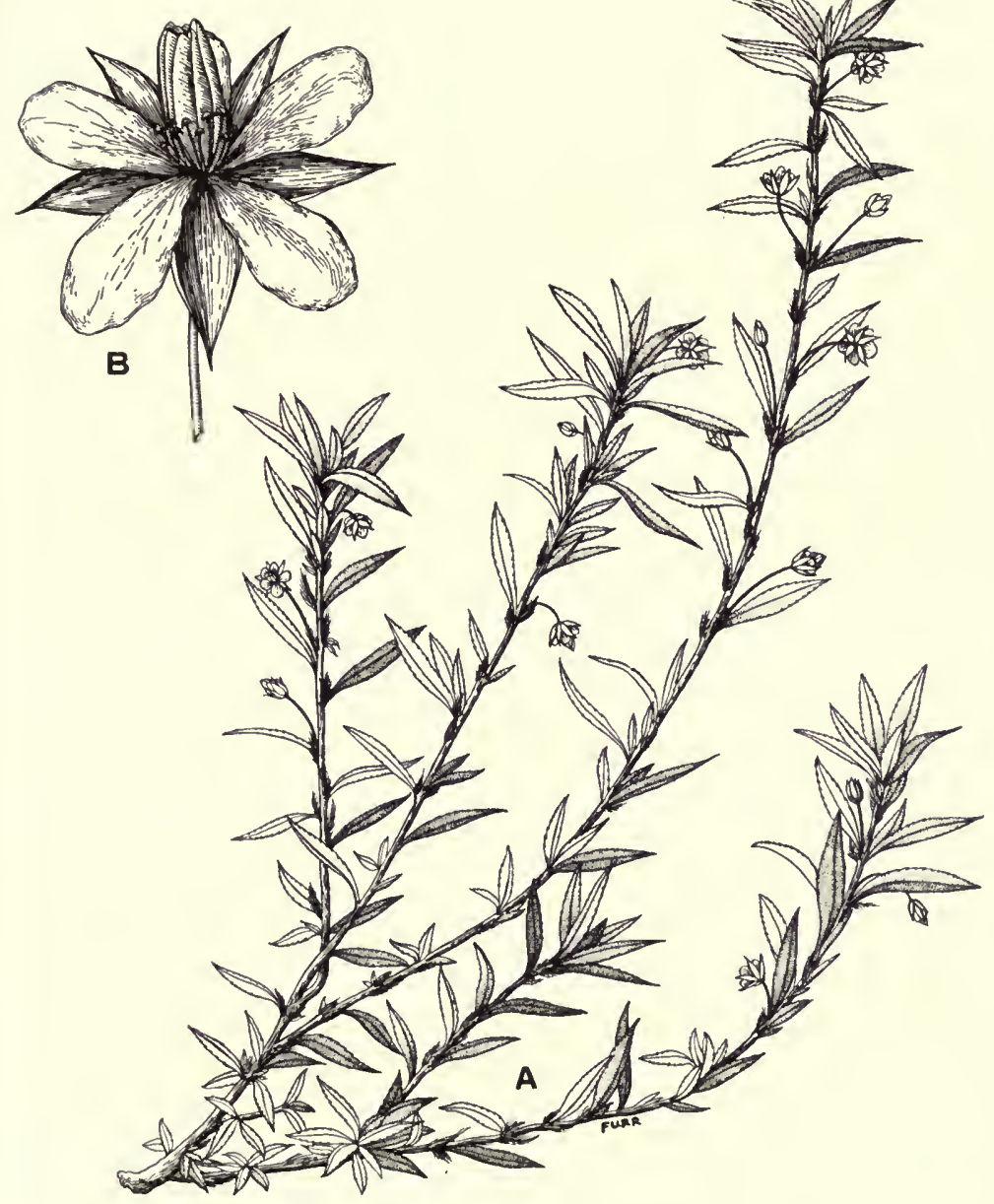

FIG. 5. Sauvagesia erecta. A, Habit; $\times 1 / 2 . \quad$ B, Flower; $\times 4$. 
Usually woody vines, often epiphytic; leaves alternate, coriaceous, entire, all alike, but the leaves of fertile and sterile branches of ten different; flowers perfect, terminal, racemose, umbellate, or paniculate, the inflorescences often pendent; bracts of ten brightly colored, highly variable in form, often modified into nectarsecreting organs; bractlets 2 , similar to the sepals and usually appressed to them; sepals 4-5, imbricate; petals 4-5, united at the base or higher and deciduous as a cap; stamens 3-many, free or united with one another and with the bases of the petals; anthers globose or elongate; ovary superior, at first 1-celled, by intrusion of the placentae becoming in age 2-many-celled; ovules numerous; style simple, short, the stigma 5-radiate; fruit capsular, coriaceous-carnose, irregularly rupturing or indehiscent; seeds numerous, small; endosperm scant or none.

Five genera, confined to tropical America. One other genus, Norantea, is represented in southern Central America.

Flowers umbellate, the central ones sterile; petals united to form a cap.

Flowers racemose, all fertile; petals free, or united only at the base.

Marcgravia.

Bracts spur-like or hat-shaped, hollow; ovary 5-celled.......... Souroubea. Bracts globose to semiglobose or carnose-spatulate, solid, not hollow . Ruyschia.

\section{MARCGRAVIA L.}

Plants usually scandent and epiphytic, glabrous or nearly so, sometimes terrestrial vines, often very large; sterile plants very different in appearance from the adult ones, usually repent on tree trunks; flowers in terminal umbelliform racemes, the bracts sac-like, stipitate in the center of the umbel, free from the pedicels; sepals 5, imbricate; petals united to form a cap-like structure that falls from the flower as a cap; stamens $12-40$, free from the corolla, generally somewhat connate at the base, the anthers linear, basifixed; ovary many-celled, the stigma sessile, obscurely radiate; ovules numerous, horizontal or ascending, anatropous, the placentae carnose; fruit globose, somewhat carnose or coriaceous, indehiscent or irregularly ruptured.

Species 40 or more, in tropical America, extending northward into Mexico. Several others are known in southern Central America.

Flowers not oblique on the pedicel, the flower in the same axis as the pedicel; leaves sessile or practically so.

Pedicels densely lenticellate, the lenticels elevated............ rectiflora.

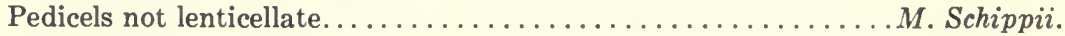

Flowers inserted obliquely on the pedicel, the axis of the flower oblique to that of the pedicel; leaves short-petiolate.

Bracts or nectaries with their pedicels about $6 \mathrm{~cm}$. long; leaves of fertile branches

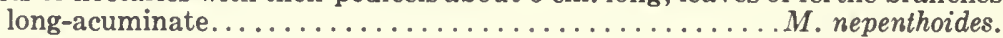

Bracts with their pedicels $2.5-3 \mathrm{~cm}$. long.

Leaves narrowly long-acuminate................ guatemalensis. Leaves acute or subobtuse.......................... Gentlei.

Marcgravia Gentlei Lundell, Contr. Univ. Mich. Herb. 6: 46. 1941. 
Known only from the type, Stann Creek District, Stann Creek Valley, Antelope Ridge, British Honduras, P. H. Gentle 3176.

A woody vine; leaves on stout petioles $3-5 \mathrm{~mm}$. long or less, rigid-coriaceous, lance-oblong to obovate-oblong, $4.5-10 \mathrm{~cm}$. long, $2.5-4 \mathrm{~cm}$. wide, acute or subobtuse, subtruncate or rounded at the base and shallowly emarginate, the lateral nerves almost horizontal, inconspicuous; umbels about 15-flowered, the pedicels $2.5 \mathrm{~cm}$. long or less, puberulent, the flowers inserted obliquely; bracts clavatetubular, about $16 \mathrm{~mm}$. long, the pedicels $8 \mathrm{~mm}$. long; stamens $11-12$, the filaments broad, compressed, about as wide as the anthers, abruptly contracted at the apex.

We have seen no material of this species.

Marcgravia guatemalensis Standl. Contr. U. S. Nat. Herb. 20: 220. 1919.

On trees in wet forest, 800-950 meters; Alta Verapaz (type from Finca Sepacuité, O. F. Cook \& R. F. Griggs 230). Costa Rica.

A slender, woody vine, glabrous almost throughout; leaves on petioles $2-3 \mathrm{~mm}$. long, narrowly lance-oblong, 9-15 cm. long, $2-4 \mathrm{~cm}$. wide, narrowly long-acuminate, rounded or very obtuse at the base, thin when dried, the lateral nerves obscure, about 13 pairs, divergent at a rather wide angle; umbels about 15 -flowered, pedunculate, the pedicels $2.5 \mathrm{~cm}$. long, puberulent, the flowers inserted obliquely; bracts about 4 , tubular-clavate, $20-23 \mathrm{~mm}$. long and $3.5 \mathrm{~mm}$. thick, the pedicels 10-12 mm. long; sepals $1-1.5 \mathrm{~mm}$. long, much broader than long, very broadly rounded at the apex; corolla ovoid, $8 \mathrm{~mm}$. long, obtuse; stamens about 12; fruit depressed-globose, $1 \mathrm{~cm}$. in diameter.

Sterile plants, especially juvenile creeping ones, probably of this species, were observed in the wet forest above Tactic at a considerably higher elevation. So far as known at present, sterile or juvenile plants can not be referred to definite species and are not worth preserving in the herbarium. There are at hand several such collections from Zacapa and San Marcos, but it is impossible to guess at their identity.

Marcgravia nepenthoides Seem. Journ. Bot. 8: 245. 1870; Hemsl. Biol. Centr. Am. Bot. 1: 90, t. 6. 1879.

Wet mixed forest, 2,500 meters or less; reported from Alta Verapaz; Izabal; Zacapa. British Honduras to Panama.

A large, woody vine, sometimes 15 meters long or more, epiphytic or terrestrial; leaves on stout petioles $7 \mathrm{~mm}$. long or shorter, chartaceous, oblong-lanceolate, 10-18 cm. long, $2.5-4.5 \mathrm{~cm}$. wide, long-acuminate, obtuse at the base, the nerves usually conspicuous beneath and reticulate; umbels 20-25-flowered, usually pendent, the stout pedicels $3-3.5 \mathrm{~cm}$. long, verrucose, the flowers inserted obliquely; bracts several, almost $4 \mathrm{~cm}$. long, galeiform, rounded at the apex, $1.5 \mathrm{~cm}$. broad at the base, on long stout pedicels; corolla about $12 \mathrm{~mm}$. long, somewhat conic. 
Called cachimba in Honduras, in reference to the inverted (when growing) bracts, which suggest tobacco pipes. This plant doubtless is common along most of the Atlantic lowlands of Central America, but the vines usually are so high in the trees that it is impractical to obtain specimens, and herbarium material is unfortunately meager. One often finds fallen bracts of flowers on the ground, but not associated with leaves. The plants of this genus have attracted much attention from naturalists, particularly Thomas Belt, because of their curious inflorescences. The bracts or nectaries excrete a kind of nectar, which is much sought by birds.

Marcgravia rectiflora Triana \& Planch. Ann. Sci. Nat. IV. 17: 364. 1862.

On trees in wet forest, 2,000 meters or lower, usually most plentiful little above sea level; Izabal (Cerro San Gil); Huehuetenango (Sierra de los Cuchumatanes). Honduras to Panama; West Indies; northwestern South America.

A large, woody vine, glabrous throughout; leaves sessile, thick-coriaceous, oblong or lance-oblong, 6-14 cm. long, short-acuminate, obtuse and somewhat oblique at the base, the nerves obsolete, the costa prominent beneath; leaves of the sterile plants much smaller, oval or oblong, obtuse or rounded at the apex; umbels rather few-flowered, the stout pedicels $4-6 \mathrm{~cm}$. long, bearing numerous large elevated lenticels; bracts cylindric-clavate, stipitate, about $2 \mathrm{~cm}$. long; sepals rounded; flowers continuous with the axis of the pedicels; corolla whitish, about $12 \mathrm{~mm}$. long; fruit globose, deep red, 1-1.5 cm. in diameter.

Marcgravia Schippii Standl. Carnegie Inst. Wash. Publ. 461: 71. 1935.

Type from Petén, in forest, Camp 32, British Honduras boundary, 840 meters, W. A. Schipp 1273; also in Huehuetenango (Cerro Chiblac, 1,200-2,000 meters).

A glabrous, woody vine 25 meters long, the stems as much as $7.5 \mathrm{~cm}$. in diameter; leaves sessile, rigid-coriaceous, oblong or lance-oblong, 7-8 cm. long, 2-3 cm. wide, narrowly obtuse, very oblique at the base, rounded on one side, acute on the other, the costa stout and prominent beneath, the lateral nerves obsolete on both surfaces; umbels about 10 -flowered, the pedicels $5 \mathrm{~cm}$. long, the axis of the flower continuous with that of the pedicel; bracts not seen; sepals broader than long, 4-6 $\mathrm{mm}$. long, truncate or broadly rounded at the apex; corolla oblong-ovoid, almost $1 \mathrm{~cm}$. long, broadly rounded at the apex; ovary globose, abruptly contracted into the short style.-The collector states that the flowers are creamcolored, the fruit red.

\section{RUYSCHIA Jacquin}

Epiphytic shrubs, usually more or less scandent, sometimes much elongate; leaves on very short, thick petioles, spirally inserted, coriaceous; inflorescences 
terminal, racemose, many-flowered; bracts inserted at the middle or above the middle of the pedicel, sessile, globose, semiglobose, or spoon-shaped, not hollow; sepals 5 ; petals 5 , united at the base; stamens 5 , alternate with the petals and united with them at the base; anthers globose; ovary 2-celled, the style evident or obsolete; radicle thicker than the cotyledons and twice as long.

Species 7-8 or perhaps more numerous, in tropical America. Two or three others are found in southern Central America.

Ruyschia enervia Lundell, Phytologia 1: 245. 1937 (type from British Honduras, Lundell 6308). R. longistylis Standl. \& Steyerm. Field Mus. Bot. 23: 175. 1944 (type from Guatemala, Steyermark 49545).

In wet forest not far above sea level; Huehuetenango; Alta Verapaz. British Honduras.

A glabrous epiphytic woody vine, the branches stout, subterete, ochraceous; leaves short-petiolate, thick-coriaceous, the thick petiole $5 \mathrm{~mm}$. long; leaf blades oblanceolate-oblong, $10-12 \mathrm{~cm}$. long, $3-3.5 \mathrm{~cm}$. wide, broadest above the middle, obtuse and mucronate-apiculate, gradually narrowed to the obtuse or subacute base, yellowish-green above when dry, slightly paler beneath, the lateral nerves obsolete; inflorescence in fruit $11 \mathrm{~cm}$. long, rather remotely many-flowered, the rachis almost $3 \mathrm{~mm}$. thick, the pedicels thick, 2.5-4 mm. long, spreading or slightly ascending; bracts inserted at the base of the calyx, semiglobose or obovate, $4 \mathrm{~mm}$. long, obtuse, narrowed to the base and substipitate, very thick; sepals strongly unequal, suborbicular, the inner ones $3 \mathrm{~mm}$. long, thick, rounded at the apex, appressed; immature fruit subglobose, $4 \mathrm{~mm}$. long, the thick columnar style $2.5 \mathrm{~mm}$. long.

\section{SOUROUBEA Aublet}

Shrubs or trees, terrestrial or epiphytic, sometimes scandent, often with numerous long pendent aerial roots; leaves short-petiolate, coriaceous, lustrous, with few or numerous glands on the lower surface; inflorescence racemose, usually elongate; bracts deciduous, the limb modified into a cylindric-clavate spur, this often deeply 2-parted at the base, or the limb sometimes sessile and spur-like or hat-like, inserted at or below the apex of the pedicel, the limb usually hollow; sepals 5, strongly imbricate; petals 5 or 3 , connate below, reflexed in anthesis, circumscissile at the base and deciduous; stamens 5 or 3, the filaments complanate, adnate to the bases of the petals; anthers ovate, dorsifixed above the base; ovary ovoid, usually 5celled, the stigma sessile, radiate; ovules numerous, ascending or subhorizontal; fruit fleshy-coriaceous, depressed-globose, indehiscent or irregularly ruptured; seeds 3-6 or fewer in each cell, the testa areolate.

About 15 species in tropical America, from Mexico southward. One additional species occurs in southern Central America. The genus has been monographed by A. C. de Roon but the monograph has not yet been published. The annotations by the monographer are not necessarily followed here. 
Lobes of the bracts about as long as the saccate portion; bracts about $25 \mathrm{~mm}$. long. S. guianensis.

Lobes of the bracts inconspicuous or none; bracts to about $10 \mathrm{~mm}$. long.

Inflorescence minutely puberulent; leaves not vernicose......S. exauriculata. Inflorescence glabrous; leaves vernicose or not.

Leaves vernicose, shining, mostly less than $10 \mathrm{~cm}$. long . . . . . . S. triandra.

Leaves not vernicose, dull, mostly more than $10 \mathrm{~cm}$. long. . . . . . . S. Gilgii.

Souroubea exauriculata Delpino, Att. Soc. Ital. Sci. Nat. Milan 12: 180. 1869; S. belizensis Lundell, Field \& Lab. 13: 8. 1945 (type from British Honduras, Gentle 4648); S. puberula Standl. \& Steyerm. Field Mus. Bot. 23: 175. 1944 (type from Guatemala, Steyermark 46862).

In wet forest or wet open slopes in the mountains. Suchitepequez; Huehuetenango. Mexico; British Honduras; Honduras and Nicaragua.

A scandent epiphytic shrub or occasionally a small tree, glabrous except the puberulent inflorescence, the branches stout, brownish or ochraceous, obtusely subangulate; leaves short-petiolate, subcoriaceous, oblanceolate-oblong, 5-12 cm. long and $2-4.5 \mathrm{~cm}$. broad, obtuse to very obtuse at the apex, mucronate-apiculate, broadest above the middle, gradually narrowed to acute or attenuate at the base, lateral nerves slender and inconspicuous; petioles short, 5-9 $\mathrm{mm}$. long; inflorescence terminal, sessile or short-pedunculate, dense, many-flowered, 7-20 cm. long, minutely puberulent in all parts, pedicels $6-10 \mathrm{~mm}$. long, stout; bracts inserted at the base of the calyx, about $10 \mathrm{~mm}$. long; sepals closely imbricated, orbicular, 2.5-5 $\mathrm{mm}$. long, rounded at the apex.

Perhaps the commonest species of the mountains of northern Central America. Souroubea mexicana Baill. is another synonym.

Souroubea Gilgii Al. Richter ex Gilg \& Werderm. in Engler \& Prantl, Nat. Pflanzenfam. ed. 2, 21: 102. 1925, nomen subnudum.

Wet forest area, mostly at low elevations. Izabal. Honduras; Nicaragua; Costa Rica; Panama.

Weak vines or shrubs; leaves oblanceolate to oblong-obovate, obtuse to somewhat acute, apiculate, cuneate or attenuate to the base, 10-18 cm. long and 4-7 cm. broad, subcoriaceous; petioles thick and short, 1-3 $\mathrm{mm}$. long; inflorescence to $25 \mathrm{~cm}$. long, spicate, the rachis thickened and fleshy; sepals suborbicular, 2-3 mm. long; corolla sympetalous, 4-5-lobed, 5-8 mm. long; bract 10-14 mm. long, biauriculate at the apex, the auricles $2-4 \mathrm{~mm}$. long, the sac subcylindric, scrotiform at the base, 8-10 mm. long.

The species seems not to have been properly published but it appears to be distinct. 
Souroubea guianensis Aubl. Pl. Guian. 244, t. 97. 1775. Ruyschia guianensis Sw. Fl. Ind. Occ. 1: 504. 1797. Souroubea sympetala Gilg in Engler, Bot. Jahrb. 25, Beibl. 60: 32.1898.

Dense, wet, mixed forests at sea level or but little above. Izabal. British Honduras to Panama; northern South America.

A small to large epiphytic vine with thick branches and usually numerous long flexible aerial roots; leaves obovate to oblong-obovate, $5-15 \mathrm{~cm}$. long, rounded to subacute at the apex, obtuse or acute at the base, more or less coriaceous, fleshy when fresh, the lateral nerves inconspicuous, bearing few to numerous large glands on the lower surface, petiole short; racemes usually elongate and many-flowered, the pedicels remote, stout, $1.5-3.5 \mathrm{~cm}$. long; bracts red, the spur hollow, slender, extending below the point of attachment into two slender auricles of equal length, the whole bract to $2.5 \mathrm{~cm}$. long; sepals ovate-oblong, yellow, reflexed in anthesis; petals yellow; stamens 5 , half as long as the petals; fruit subglobose; seeds usually few, 4-5 mm. long, black.

The Central American material is apparently considered by the monographer, de Roon, to be a distinct species and has been annotated under the name of S. sympetala Gilg. I am unable to distinguish the species from the older $S$. guianensis.

Souroubea triandra Lundell, Phytologia 1: 244. 1937 (type from British Honduras, Lundell 6492); S. micrantha Standl. \& Steyerm. Field Mus. Bot. 23: 62. 1944 (type from Guatemala, Standley 72793).

Wet forests at relatively low elevations. Izabal; Alta Verapaz. British Honduras; Costa Rica.

A glabrous epiphytic shrub; leaves oblanceolate to obovate-elliptic, 5-12 cm. long and 2-6 cm. broad, rounded or very obtuse at the apex, attenuate or acute at the base, subcoriaceous, vernicose or lustrous, petioles $3-8 \mathrm{~mm}$. long; racemes 5$16 \mathrm{~cm}$. long, 1.5-2 cm. broad, many-flowered, the pedicels stout, divaricate or somewhat reflexed, 5-9 mm. long; bracts tubular-cylindric, $8-10 \mathrm{~mm}$. long, inserted at the base of the calyx, short stipitate; sepals orbicular, $1.8 \mathrm{~mm}$. long or less; corolla about $4.5 \mathrm{~mm}$. long, 3-4-lobate to the middle; irregularly cleft in anthesis, the lobes reflexed, obtuse; stamens 3-4; ovary 3-4-celled.

The monographer, de Roon, has applied an unpublished specific combination to this species which, when published, may replace the name $S$. triandra.

\section{QUIINACEAE}

Trees or shrubs, sometimes scandent; leaves opposite or verticillate, simple and entire or dentate or sometimes pinnate, penninerved, finely transverse-lineolate between the nerves; stipules usually geminate, narrow, stiff, persistent; flowers small, polygamous, in terminal or axillary panicles; sepals $4-5$, imbricate; petals usually $4-5$, sometimes $6-8$, alternate with the sepals, imbricate or contorted in bud; stamens 15-30, free or connate at the base, the filaments filiform; anthers 
small, globose-didymous, the cells dehiscent by slits; ovary 2-3-celled or 7-11celled; styles distinct, linear, stigmatose at the apex; ovules 2 in each cell, ascending; fruit baccate, finally dehiscent, of ten by abortion 1-celled, 1-3-seeded, the endocarp fibrous; seeds ovoid or globose, tomentose.

Genera about 3, all tropical American. One other, Lacunaria, is represented in Panama.

\section{QUIINA Aublet}

Trees or shrubs, sometimes scandent; leaves opposite, entire or dentate or sometimes pinnate, short-petiolate, coriaceous; stipules foliaceous, erect; flowers very small, short-pedicellate, in clusters of $2-3$ in the axils of bracts, arranged in very small, few-flowered panicles; sepals $4-5$; petals $4-5$, rarely 6-8; stamens 15-30; ovary 2-3-celled; styles $2-3$, linear; fruit an almost dry berry, usually 1-celled and 1-3-seeded.

About 15 species, chiefly in the Guianas and Brazil, with only the following species in North America.

\section{Quiina Schippii Standl. Field Mus. Bot. 8: 26. 1930.}

British Honduras, in wet forest little above sea level, the type from Middlesex, Schipp 238; to be expected in Petén and Izabal; Honduras (Lake Yojoa, 600 meters). Figure 6.

An almost glabrous tree 6-18 meters high, the young branchlets appressedpilose with fulvous hairs; stipules linear or linear-subulate, 7-15 $\mathrm{mm}$. long; leaves opposite, on stout petioles $3-5 \mathrm{~mm}$. long, oblong-lanceolate, $8-20 \mathrm{~cm}$. long, $2-7 \mathrm{~cm}$. wide, narrowly long-acuminate, gradually attenuate to the base, green and lustrous above, paler beneath, the lateral nerves about 9-13 pairs, ascending, curved; racemes solitary or fasciculate, $1-4.5 \mathrm{~cm}$. long, simple, with few-many fiowers, the bracts ovate, acute, ciliate, the rachis densely hirtellous, the pedicels $1.5-3 \mathrm{~mm}$. long, glabrous; sepals 4 , oval or rounded, $1.5-1.8 \mathrm{~mm}$. long, rounded at the apex, ciliate; petals 4 , rounded, $2.5 \mathrm{~mm}$. long, glabrous, white, ciliolate; stamens shorter than the petals; fruit oblong, $8 \mathrm{~mm}$. long, bright red, obtuse or subtruncate at the apex.

The name "pigeon plum" is reported from British Honduras.

\section{THEACEAE. Tea Family}

Trees or shrubs with deciduous or usually persistent leaves; leaves alternate, simple, entire or serrate, without stipules; flowers usually perfect, regular, small or large, axillary or subterminal, generally solitary; sepals 5-7, rarely more numerous, imbricate, usually persistent; petals 5 , rarely 4 or more, distinct or connate at the base; stamens very numerous, rarely only 5,10 , or 15 , free or united at the base, often adnate to the petals; ovary superior or rarely inferior, $2-10$-celled, the cells 1-many-ovulate; styles as many as the carpels or connate into one; fruit a loculicidal capsule, or indehiscent and dry or drupaceous; seeds 1-many; endosperm none or scant; embryo usually curved. 


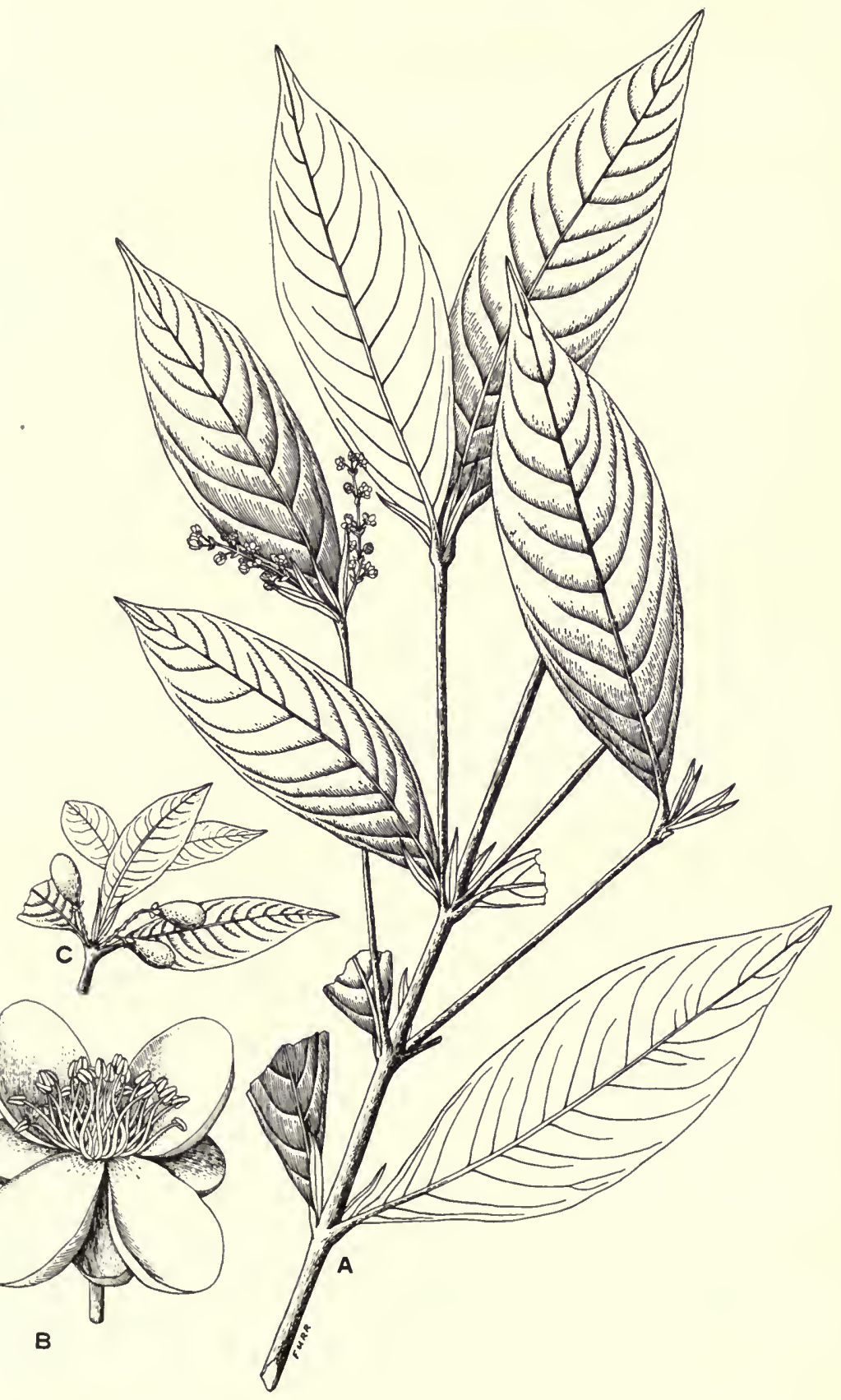

FIG. 6. Quiina Schippii. A, Branch showing leaves and inflorescence. B, Flower; $\times 10$. C, Portion of branch, showing fruits. 
About 18 genera, with most of their species in tropical or subtropical regions of both hemispheres. One other genus, Pelliciera, is represented in southern Central America.

Anthers versatile; fruit capsular.

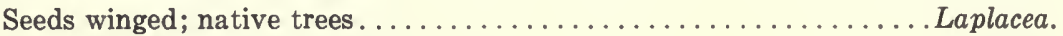

Seeds not winged; cultivated shrubs.................... Camellia.

Anthers basifixed; fruit indehiscent.

Leaves, at least usually, densely tomentose or sericeous beneath; anthers glabrous................................... Freziera.

Leaves glabrous or glabrate beneath, at least in age.

Ovary inferior; leaves crenate-serrate................ Symplococarpon. Ovary superior.

Anthers pilose; leaves (in Guatemalan species) serrulate; bractlets minute. Cleyera.

Anthers glabrous; leaves entire or obscurely serrulate; bractlets large and conspicuous............................ Ternstroemia.

\section{CAMELLIA L.}

Trees or shrubs; leaves persistent, coriaceous or membranaceous, serrate; flowers often large and showy, axillary, solitary or clustered, sessile or shortpedicellate; sepals 5-6, unequal; petals short-coherent at the base, strongly imbricate; stamens numerous, many-seriate, united at the base or almost to the apex, the inner ones free, the anthers versatile; ovary 3-5-celled, the styles free almost to the base, or more or less united; ovules 4-5 in each cell, pendulous; capsule ligneous, loculicidally dehiscent; seeds usually solitary in each cell; endosperm none.

About 45 species, in tropical and subtropical Asia.

Camellia japonica L. Sp. Pl. 698. 1753. Camelia.

Native of China and Japan; planted widely for ornament in warmer regions of the earth; grown commonly for ornament in Guatemala, chiefly in the mountains, at lower elevations planted in the ground, in the higher mountains often grown in pots.

A shrub or small tree, glabrous throughout or nearly so, with leathery, deep green, ovate to elliptic leaves $5-10 \mathrm{~cm}$. long. The large flowers are primarily red, but they vary to white, and there are many varieties.

The camellia seems to thrive in Guatemala at middle elevations, but at the highest elevations, as in San Marcos, it is sometimes injured by the cold, and it does not grow well out of doors at Quezaltenango, where the flowers bring a price that is very high for Guatemala.

Camellia sinensis (L.) Kuntze, Act. Hort. Petrop. 10: 195. 1887. Thea sinensis L. Sp. Pl. 515. 1753. Camellia Thea Link, Pl. Hort. Berol. 2: 73. 1822. Té. Tea. 
Native of China and India; planted occasionally in Guatemalan gardens for ornament or as a curiosity; formerly planted on a commercial scale at Finca Chirripec near Cobán, Alta Verapaz.

The tea of commerce is obtained from the dried, young and tender leaves of this shrub. Tea from the Orient is imported normally into Guatemala, principally for use by foreign residents of the country. It is not a common beverage among native Central American people. The tea plantation at Finca Chirripec was a fairly large one, and is said to have furnished the greater part of the tea used in Guatemala. The plant for drying and aging the leaves was a small building, and it is evident that the amount produced was not very great. It was marketed in two distinct grades, in cartons weighing from one ounce upward. The Guatemalan tea gardens were very neat and pretty in appearance and looked just like the pictures of the tea gardens of India and Ceylon, the terrain and the climate being much the same. For the successful production of tea, a mild cool climate with permanently moist air is needed, and these conditions seem to have been found at Chirripec. So far as we know, this was the only large commercial tea plantation in Central America. The labor was performed by Quecchí Indians of the vicinity, principally by women. Little or no tea is harvested in Guatemala now because of the high cost of harvesting.

\section{GLEYERA Thunberg}

Reference: Clarence E. Kobuski, Studies in the Theaceae, VII. The American species of the genus Cleyera, Journ. Arn. Arb. 22: 395-416. 1941.

Trees or shrubs; leaves persistent or deciduous, serrulate (in Guatemalan species) or entire; flowers perfect, axillary or borne at leafless nodes, solitary or fasciculate, the pedicels usually about $1 \mathrm{~cm}$. long, thickened slightly toward the apex, 2-bracteolate, the bracteoles small to minute, subopposite or alternate near the apex of the pedicel; sepals 5, imbricated, unequal, the outer ones smallest, ciliolate usually; petals 5 , imbricate, connate at the base; stamens about 25 , the anther setose, 2-celled, opening by longitudinal slits; ovary usually glabrous, 2-3-celled, many-ovulate; styles elongate, 3-4-fid; fruit indehiscent, baccate, globose or ovoid, many-seeded; endosperm scant, the embryo curved.

About ten species are known from mountain regions of tropical America, and a few others occur in Asia. No other species is known in Central America.

Cleyera theaeoides (Sw.) Choisy, Mem. Soc. Phys. Hist. Nat. Genève 14, 1: 110. 1855; L. Wms. Fieldiana, Bot. 29: 353. 1961. 
Eurya theaeoides (Sw.) Blume, Mus. Bot. Ludg.-Bat. 2: 105. 1856. Cleyera Matudai Kobuski, Journ. Arn. Arb. 22: 403.1941 (type from Mexico, Matuda 2560). C. revoluta Kobuski, l.c. 405 (type from Guatemala, Steyermark 36208). C. tacanensis Kobuski, l.c. 406 (type from Guatemala, Steyermark 36052). C. Skutchii Kobuski, l.c. 405 (type from Guatemala, Skutch 545). Tabojilla; cormén; baratillo; fruta de cabro.

Often in open cloud forests or in drier pine-oak forests, 1300 to 3000 meters. El Progreso; Zacapa; Alta Verapaz; Baja Verapaz; San Marcos; Quiché; Chiquimula; Jalapa; Guatemala; Suchitepéquez; Chimaltenango; Quezaltenango. Mexico (Chiapas); El Salvador; Honduras; Nicaragua; Costa Rica; Panama. Figure 7.

A rather large shrub or, when well grown, an attractive tree to $20 \mathrm{~m}$. tall; branchlets pubescent but usually becoming glabrous; leaves short-petiolate, oblong-elliptic to obovate or broadly oval, coriaceous, glabrous or slightly pubescent on the petiole and on the back of the leaf, crenulate-dentate, occasionally obscurely so, cuneate to the base, apex acuminate, (usually) obtuse, blade 2-15 cm. long and 1-6 $\mathrm{cm}$. broad, lateral nerves 10-12 pairs; flowers solitary or fascicled from the twigs or the leaf axils; pedicels 5-20 mm. long, glabrous or puberulent, with two subopposite deciduous bracts near the flower; sepals 5 , unequal, rounded, the outer ones pubescent, puberulent, or glabrous, sometimes verriculate, usually ciliolate, 2-4 mm. long; petals usually 5 , white or greenish-yellow, sometimes emarginate, 5-8 mm. long; stamens about 25, the anther sparsely pubescent or glabrous; ovary glabrous or puberulent, 3-celled; styles 3 , free from about the middle to almost the base.

The Indian name "Yxinché" is reported by García Salas for Chimaltenango. The tree is called coyolillo or cacao in Honduras, both names better known for other plants. Most Guatemalan specimens of this species have been reported as Eurya theoides or as Cleyera Skutchii. The leaves on flowering growths are usually smaller than those on sterile growths or those of a previous season. Kobuski has divided this species into several which it seems impossible to separate. The characters relied upon for separation are too inconsistent for use.

\section{FREZIERA Swartz}

Reference: Clarence E. Kobuski, Studies in the Theaceae, VIII. A synopsis of the genus Freziera, Journ. Arnold Arb. 22: 457-496. 1941.

Trees or large shrubs; leaves mostly coriaceous, lightly serrulate or subentire, petiolate; flowers small, dioecious, fasciculate in the leaf axils or on short flowering branchlets; bractlets 2 , opposite, at the apex of the pedicel; sepals 5 , imbricate, 


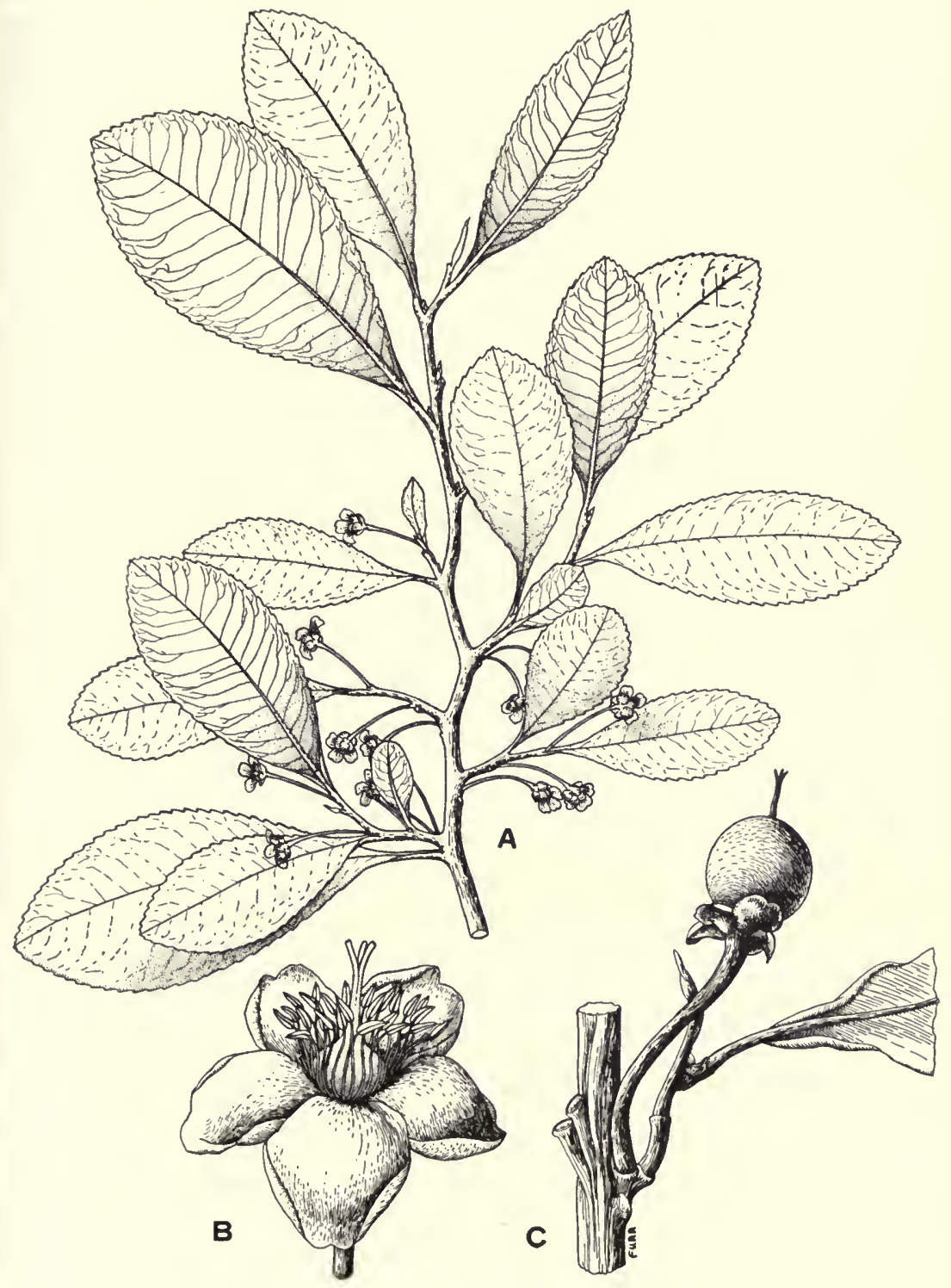

Fig. 7. Cleyera theaeoides. A, Portion of flowering branch. B, Flower; $\times 4$. C, Fruit; $\times 4$. 
persistent; petals 5, imbricate, unequal, usually free to the base; stamens 15-30 in the staminate flowers, 1-seriate, the filaments adnate to the bases of the petals; anthers linear or ovate-elliptic, glabrous, usually dehiscent to the base; ovary glabrous, 3-5-celled, attenuate into an entire style, the ovules numerous; staminodia of the pistillate flower fewer than the stamens; fruit indehiscent, conic-globose; seeds $10-50$ in each cell, small.

Species about 34, in tropical America, mostly in mountain regions. Two or three other species are known from southern Central America.

Leaves covered beneath with a dense ferruginous tomentum of matted and entangled hairs . . . . . . . . . . . . . . . . . . . . . . .

Leaves pilose beneath with spreading or appressed, not matted, mostly straight hairs.

Leaves densely and conspicuously papillose along and near the costa on the upper surface.......................... macrophylla.

Leaves smooth on the upper surface, not at all papillose......F. Grisebachii.

Freziera Friedrichsthaliana (Szysz.) Kobuski (Eurya Friedrichsthaliana Szysz.) was reported originally as a native of Guatemala, and based upon Friedrichsthal 996. The plants of this collection, while all labeled as coming from Guatemala, were collected in large part in other Central American countries. The species has been collected twice in Nicaragua, and not recently in Guatemala. Since the collector is known to have collected plants in Nicaragua, it is best to delete this species from the list of Guatemalan plants, at least for the present.

Freziera Grisebachii Krug \& Urban, Bot. Jahrb. 21: 542. 1896. Eurya lancifolia Standl. Field Mus. Bot. 8: 317. 1931 (type from British Honduras, Schipp 455). F. lancifolia Kobuski, Ann. Mo. Bot. Gard. 25: 354. 1938.

Moist or wet, mixed forest, 120-825 meters; Petén (Camp 36, British Honduras boundary, W. A. Schipp S710). British Honduras.

A tree of $15-18$ meters, the trunk $30 \mathrm{~cm}$. in diameter, the branches thinly appressed-pilose with fulvous hairs, in age glabrate; leaves on petioles $1-1.5 \mathrm{~cm}$. long, thin, lance-oblong, 10-14 cm. long, 3-4.5 cm. wide, acuminate or longacuminate, rounded at the base, serrulate, glabrous on the upper surface except along the costa, slightly paler beneath, pilose with usually closely appressed hairs, the lateral nerves arcuate; flowers axillary or at defoliated nodes, fasciculate or on very short peduncles, the pedicels in fruit rather slender and 3-5 $\mathrm{mm}$. long; sepals suborbicular, $3-3.5 \mathrm{~mm}$. long, densely sericeous; fruit subglobose, $7 \mathrm{~mm}$. long, 3-celled, glabrous. 
Freziera guatemalensis (Donn.-Sm.) Kobuski, Ann. Mo. Bot. Gard. 25: 354. 1938. Eurya guatemalensis Donn.-Sm. Bot. Gaz. 46: 109. 1908. Huel colorado (Huehuetenango); alajix (Cobán, Quecchí).

Mostly in moist or wet pine forest, 900-2000 meters; Alta Verapaz (type from Cobán, Tuerckheim II. 1824); Guatemala; Huehuetenango. Mountains of Honduras.

A small or large tree sometimes 12 meters high, with long, rather slender, rufous-tomentose branches; leaves on short stout petioles, lance-oblong, 10-20 cm. long, 3-6 $\mathrm{cm}$. wide, acuminate or long-acuminate, rounded or obtuse at the base, entire or serrulate, green above, glabrous or practically so, covered beneath with a dense persistent tomentum of ferruginous matted hairs, coriaceous or chartaceous, the lateral nerves in numerous pairs, almost straight; flowers axillary or at defoliated nodes, on very short, few-flowered, stout peduncles, the pedicels 5-7 and $4 \mathrm{~mm}$. long or less, thick; flowers $8 \mathrm{~mm}$. long; sepals suborbicular, ferruginoustomentose; petals $7 \mathrm{~mm}$. long; stamens glabrous.

The wood is used commonly about Cobán for firewood. The wood in this genus is dull brownish or reddish brown, hard and heavy or moderately so. Kobuski refers to $F$. guatemalensis collections which we find better referable to $F$. macrophylla.

Freziera Karsteniana (Szysz.) Kobuski, Ann. Mo. Bot. Gard. 25: 354. 1938. Eurya Karsteniana Szysz. in Engl. \& Prantl, Nat. Pflanzenfam. II. 6: 190. 1893. This was described originally as from Guatemala, but it has been found that the species is actually native in Colombia.

Freziera macrophylla Tulasne, Ann. Sci. Nat. Bot. III. 8: 330. 1842. Durazno de monte.

Moist or wet, mixed, mountain forest, 1,400-2,500 meters; Quezaltenango; San Marcos. Mexico (Oaxaca).

A small tree, sometimes 9 meters high, the branches densely fulvous-pilose with spreading or subappressed hairs; leaves on short thick petioles, lance-oblong, $12-25 \mathrm{~cm}$. long, 4-6.5 $\mathrm{cm}$. wide, acuminate or narrowly long-acuminate, obtuse or rounded at the base, serrulate, green above (when dry yellow-green), glabrous except along the costa, conspicuously and densely verrucose near the costa, fulvouspilose beneath with soft, spreading or often appressed hairs, the lateral nerves 20-25 pairs, almost straight or slightly arcuate; flowers borne in the leaf axils and at defoliated nodes, subsessile or on pedicels $2-4 \mathrm{~mm}$. long; sepals suborbicular, coriaceous, $3-4 \mathrm{~mm}$. long, the outer ones densely pubescent; petals glabrous, creamy white, twice as long as the sepals; stamens about 15; ovary glabrous; fruit globose, 5 -celled.

The specimens from Guatemala, in part referred by Kobuski to $F$. guatemalensis, seem to agree perfectly with authentic material of $F$. macrophylla, and to be certainly different from $F$.guatemalensis. 


\section{LAPLACEA HBK.}

Reference: Clarence E. Kobuski, Studies in the Theaceae, XX. Notes on the South and Central American Species of Laplacea, Journ. Arn. Arb. 31: 405-429. 1950.

Shrubs or large trees, glabrous or pubescent; leaves coriaceous, more or less dentate; flowers pedicellate, axillary, sometimes large and showy; sepals 5, unequal, the calyx bracteolate at the base; petals 5 , slightly coherent, strongly imbricate; stamens numerous, the outer ones or all of them more or less connate or in 5 groups, adherent to the base of the petals, the anthers versatile; ovary 5-10-celled, the styles short and divergent or the stigmas sessile and distinct; ovules 4-8 in each cell, pendulous; fruit capsular, of ten ligneous, broadly oblong, loculicidally dehiscent, the columella persistent; seeds compressed or flat, produced at the apex into an oblong wing; endosperm none, the embryo straight, the cotyledons oblong, flat, the radicle short, superior.

About 30 species, in tropical America and the East Indies. Two other species occur in southern Central America.

Laplacea coriacea L. Wms. Fieldiana, Bot. 29: 354. 1961 (type from Guatemala, Steyermark 42880).

Probably cold cloud forest. Endemic. Zacapa.

Shrubs or trees of unknown size; branchlets many, terete, glabrous. Leaves toward the apex of the branches and branchlets, stiff-coriaceous, completely glabrous, symmetrical or slightly asymmetrical, broadly oval to broadly obovate, obtuse, the margins entire or slightly undulate, the blade $4-8 \mathrm{~cm}$. long and $2.5-5 \mathrm{~cm}$. broad, often decurrent into the petiole; the nerves 7-12 pairs, nearly plain above, slightly canaliculate beneath, the mid-rib plain above, elevated beneath; the petiole to $1.5 \mathrm{~cm}$. long, subglandular, sometimes winged; inflorescences axillary, flowers solitary; peduncle terete, 1-2.5 cm. long; sepals 5, imbricated, about $3 \mathrm{~mm}$. long and twice as broad, fleshy and coriaceous, ciliolate, otherwise glabrous; petals unknown; stamens unknown; ovary elliptic-ovoid, densely sericeous; stigma stellate, 5-lobed; capsule ovoid, about $1.5 \mathrm{~cm}$. long and $0.8 \mathrm{~cm}$. thick, 5-loculate.

This species has been confused by both Standley and Kobuski with Laplacea grandis and into it have been placed specimens of that species, the specimen on which this species is based, and several specimens belonging in the Sabiaceae and in another family. The very broad, thick, obtuse leaves of $L$. coriacea are characteristic.

\section{SYMPLOCOCARPON Airy-Shaw}

Reference: Clarence E. Kobuski, Studies in the Theaceae, VI. The genus Symplococarpon Airy-Shaw, Journ. Arnold Arb. 22: 188-196. 1941.

Trees, glabrous or pubescent; leaves alternate, entire or serrate, more or less coriaceous; flowers perfect, axillary, fasciculate, the pedicels minutely bracteate 
at the base and with 2 persistent bractlets, opposite or nearly so, at the juncture of the pedicel and hypanthium; sepals 5 , imbricate, persistent; petals 5 , alternate with the sepals, imbricate, slightly connate at the base; stamens $25-40$, uniseriate, the filaments connate at the base and adnate to the base of the corolla; anthers oblong-elliptic, narrowed at the apex into a subulate mucro; ovary inferior, 2-celled; ovules usually solitary in each cell, sometimes more numerous; styles 2 , rarely 3 , free; fruit indehiscent, subglobose, crowned by the persistent calyx and styles, 2-celled, usually 2-seeded.

Seven species, ranging from central Mexico to Panama. Three are known in Costa Rica and Panama.

Symplococarpon lucidum Lundell, Bull. Torr. Bot. Club 69: 394. 1942. Pasa macho. Wild raisin male.

Known only from British Honduras, type Gentle 3248; Conservator of Forests 85.

A small tree, the bark dark green, glabrous except for the whitish-strigose buds, the branchlets slender, reddish; leaves on rather stout petioles $2.5-4.5 \mathrm{~mm}$. long, membranaceous or chartaceous, elliptic-oblong to oblanceolate or lanceolate, 4-10 $\mathrm{cm}$. long, 2-4.5 cm. wide, yellowish green and usually lustrous above, obtuseacuminate, cuneate at the base, crenate-serrate, the lateral nerves 6-9 pairs, the veins reticulate; flowers in clusters of 9 or fewer, the pedicels slender, in bud $1 \mathrm{~cm}$. long, usually recurved, the bractlets ovate, ciliate, 9.6-0.8 mm. long; hypanthium glabrous; calyx lobes depressed-orbicular, ciliate; stamens about 30 ; free portion of the ovary sparsely hirsute; styles 2 ; cells of the ovary 2-3-ovulate.

It is questionable whether or not this species is distinct from $S$. Brenesii Kobuski from southern Central America. The wood is reported to be pink.

\section{TERNSTROEMIA Mutis}

Reference: Clarence E. Kobuski, Studies in the Theaceae, XIII. Notes on the Mexican and Central American species of Ternstroemia, Journ. Arnold Arb. 23: 464-478. 1942.

Glabrous trees or shrubs; leaves spirally disposed, of ten congested or verticillate at the ends of the branches, usually coriaceous, mostly entire or nearly so; flowers axillary, solitary, bracteolate; bractlets generally 2, opposite or subopposite, at the base of the calyx or one of them somewhat distant; flowers perfect; sepals usually 5, imbricate, persistent, coriaceous; petals mostly 5, free or more or less connate; stamens 25-300, usually 2-seriate, the filaments connate, the outer ones adnate to the bases of the petals; anthers mostly longer than the filaments, oblong or linear, the connective usually produced into an appendage; ovary 2-3-celled, rarely 1-celled, or falsely 4-6-celled; ovules 2-20 in each cell, rarely solitary, pendulous from the apex of the placenta; style 1, entire or rarely 2-3-parted; fruit indehiscent, coriaceous; seeds few, the testa usually smooth. 
A tropical genus, with 85 species or more, mostly in tropical America and Asia. Two or perhaps three other species are known from Central America.

Ternstroemia Tepezapote Schlect. \& Cham. Linnaea 6: 420 . 1831. T. Seleriana Loes. Bull. Herb. Boiss. II. 3: 213.1903 (type from Chaculá, Huehuetenango, Seler 3099). T. impressa Lundell, Bull. Torr. Bot. Club 66: 599. 1939 (type from Chiquihuite, Volcán de Tacaná, Chiapas, E. Matuda 2814). Taonabo sphaerocarpa Rose, Contr. U. S. Nat. Herb. 8: 322. 1905. Ternstroemia sphaerocarpa Melchior, Nat. Pflanzenfam. ed. 2. 21:142. 1935. Baratillo (Jalapa); trencillo (Chiquimula); chucul (Huehuetenango); hualicuc (Huehuetenango); uixlilil-caax (Petén, Maya, fide Lundell); panool, chique, roble (Petén, fide Lundell).

Moist or wet thickets or mixed forest or pine forest, sometimes on limestone, 3,150 meters or lower; Petén; Alta Verapaz; El Progreso; Izabal; Zacapa; Chiquimula; Jalapa; Santa Rosa; Guatemala; Suchitepéquez; Huehuetenango; Chimaltenango; Quiché; Sololá. Southern Mexico; British Honduras; Honduras; El Salvador. Figure 8.

A shrub or tree, sometimes 15 meters high, with a trunk $15 \mathrm{~cm}$. or more in diameter; leaves oblong-obovate or oblong-oblanceolate, $7-13 \mathrm{~cm}$. long, mostly 3-4 cm. wide, obtuse or rounded at the apex or sometimes subacute, cuneate or attenuate at the base, entire or obscurely crenulate, the nerves inconspicuous on both surfaces, sometimes impressed above; pedicels $1.5-2.5 \mathrm{~cm}$. long, the bractlets 2 , opposite, unequal, broaculy ovate or suborbicular, 2-3 $\mathrm{mm}$. long; sepals unequal, the outer ones suborbicular, about $8 \mathrm{~mm}$. long, glandular-denticulate, of ten conspicuously so, or sometimes entire, petals pinkish white, lanceolate or ovate, $8 \mathrm{~mm}$. long, acute, united half their length; stamens about 50 and 2-seriate; ovary 2-celled, each cell 4-5-ovulate, the style 6-7 $\mathrm{mm}$. long, the stigma punctiform; fruit conic or ovoid-conic, 1-2 cm. long, 1-1.5 cm. broad at the base.

Called "river craboo" in British Honduras; "trompillo" (El Salvador). Kobuski recognizes as a distinct species Ternstroemia impressa, principally because the nerves are slightly impressed on the upper surface. To it he refers a specimen from Soloma, Huehuetenango, and another from Jalapa could be placed with it. This character, however, appears to be a matter of degree, and the species appears to be a quite untenable one, the more so when he reduces to synonymy under T. Tepezapote four species described from Mexico that probably have quite as good claims to specific status. Several of the Guatemalan specimens could be referred to $T$. megaloptycha Kobuski (Journ. Arnold Arb. 23: 474. 1942), which was based upon numerous collections from Honduras. It is keyed by Kobuski as having larger flowers than $T$. Tepezapote, but there appears to be every gradation 


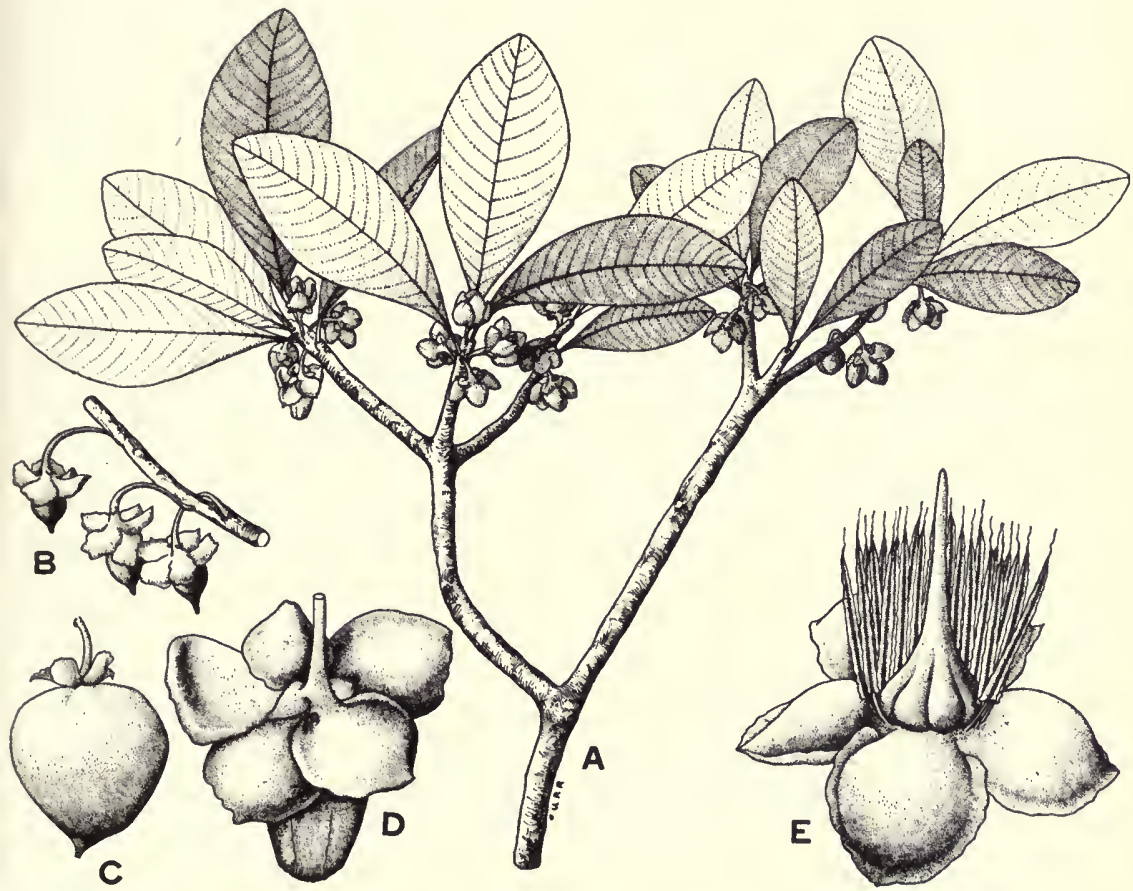

FIG. 8. Ternstroemia Tepezapote. A, Flowering branch from tree; $\times 1 / 2$. B, Fruits; $\times 1 / 2$. C, Fruit; $\times 1 \frac{1}{2}$. D, Flower, showing bractlets and calyx. E, Flower; $\times 4$. 
in this respect, and it should be referred to synonymy under the latter. Apparently there is nothing besides geographic range to separate the two. This tree is remarkable for its wide altitudinal distribution in Guatemala, although in this respect it is equalled by many other trees. In Huehuetenango it is reported that a decoction of the bark is employed as one of the numerous "remedies" for snake bites. The specific name Tepezapote is one of the Nahuatl names given to this tree in Mexico. In this genus the heartwood exhibits various shades of brown; luster low; of medium density but hard and strong; grain variable; not difficult to work and finishes smoothly; durability doubtful. So far as known, no use is made of the wood in Guatemala, unless for firewood.

\section{GUTTIFERAE}

Reference: Juliano Vesque in DC. Monog. Phan. 8: 1-669. 1893.

Trees, shrubs, or often herbs, terrestrial or epiphytic, dioecious, polygamous, or perfect, sometimes with aerial roots, the sap frequently yellow and resinous, the leaves and petals sometimes with black or transparent dots or lines; leaves mostly opposite and decussate, penninerved, simple, entire, without stipules, sometimes with a marginate pit in the axillary part of the petiole; flowers generally white or yellow, sometimes pink, in chiefly terminal inflorescences, sometimes solitary, regular or nearly so, the pedicels often bracteolate, the bractlets usually resembling sepals; sepals variable in number, sometimes unequal; petals variable in number, free or nearly so; disk sometimes present; stamens numerous in the staminate flowers. rarely definite, free or variously connate, all fertile or the inner or outer ones reduced to staminodia; anthers various in form; pistillate flowers with staminodia, the ovary superior, 1-many-celled; ovules 1-many in each cell, axile or attached to the septa, rarely basal or parietal; stigmas sessile or on free or partly connate styles; fruit capsular, opening septicidally or rarely loculicidally, sometimes baccate or drupaceous; seeds often enveloped in an aril, without endosperm.

About 45 genera, the species most numerous in tropical regions. Another genus represented in southern Central America is Chrysochlamys.

Leaves abundantly tomentose on the lower surface with branched hairs...Vismia. Leaves glabrous.

Fruit dehiscent.

Cells of the ovary 1 -ovulate.............................

Cells of the ovary 2-many-ovulate.

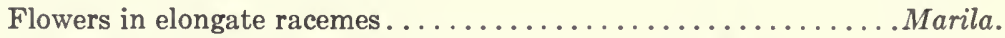

Flowers solitary, cymose, or paniculate, never racemose.

Flowers dioecious or polygamous; large shrubs or trees, with large, mostly

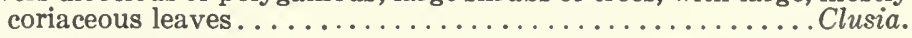

Flowers perfect; herbs or small shrubs, rarely small trees, the leaves thin, usually very small. 


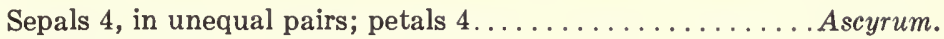

Sepals and petals each 5 , the petals equal or nearly so.....Hypericum.

Fruit indehiscent.

Leaves with very numerous, fine lateral nerves, the nerves mostly less than $1 \mathrm{~mm}$. apart, not or obscurely connected by transverse nerves.

Calophyllum.

Leaves with few lateral nerves, or the nerves sometimes numerous but connected by conspicuous transverse nerves.

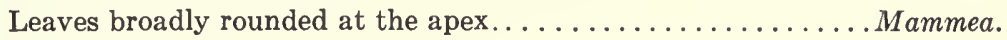

Leaves acute or acuminate.

Stamens connate into a tube, this split above into 5 spreading lobes;

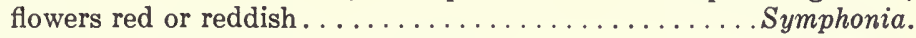

Stamens free; flowers white or yellowish ............. Rheedia.

\section{ASCYRUM L.}

Low perennials, somewhat woody, densely leafy, in appearance like Hypericum; leaves small, entire; flowers yellow, small, subternate at the ends of the branches; sepals 4 , the 2 outer ones large, or all the sepals subequal; petals 4 , naked within; stamens short-connate at the base or free; hypogynous glands none; ovary 1-celled, the $2-3$, rarely 4 , placentae parietal; styles free or coherent at the very base; ovules numerous; capsule dehiscent along the placentae.

About 5 species, in eastern and southeastern North America, Mexico, Central America, and West Indies. Only the following reaches Central America.

Ascyrum hypericoides L. Sp. Pl. 788. 1753. Hierba de sabino (fide Aguilar).

Brushy hillsides in pine forest, 1,000-1,800 meters; Zacapa; Jalapa; Quiché; Alta Verapaz; Huehuetenango. Eastern United States; Mexico; Honduras; Cuba; Jamaica.

A low shrub, much branched from the base or throughout, glabrous, diffuse or ascending, the stems $30 \mathrm{~cm}$. long or less, the branches somewhat compressed and 2-edged; leaves sessile, oblong or obovate, $0.5-2 \mathrm{~cm}$. long, 1-4 mm. wide, obtuse, narrowed and biglandular at the base, punctate; flowers terminal and sometimes also axillary, golden yellow, short-pedicellate, $12-18 \mathrm{~mm}$. broad; outer sepals oval or ovate, sometimes cordate at the base, obtuse, the inner ones narrower and generally shorter; petals oblong-linear, about equaling the outer sepals; styles 2; capsule ovoid, $4 \mathrm{~mm}$. long.

Only the typical variety is known to occur in Central America, and it is not common. The leaves sometimes dimorphic.

\section{CALOPHYLLUM L.}

Trees with colored sap; leaves opposite, with very numerous and close, parallel lateral nerves, coriaceous, petiolate; flowers small, polygamous, the inflores- 
cences axillary or terminal, paniculate or racemose, the nodes not articulate; sepals 4, decussate; petals indefinite, none, or 1 or more, the sepals and petals of ten much alike; stamens numerous, free or slightly united by their bases, the filaments slender; anthers ovate or oblong, opening by longitudinal slits; ovary 1-celled, the ovule 1, erect, anatropous; stigma peltate, sometimes lobate; fruit drupaceous.

About 100 species, chiefly in the Old World tropics, about 7 in America. One other Central American species occurs in Panama.

Calophyllum brasiliense Camb. in St. Hil. Fl. Bras. Merid. 1: 321, pl. 6\%. 1825.

Widely distributed in tropical South America. Represented in Mexico and Central America by the following geographic variety:

Calophyllum brasiliense var. Rekoi Standl. Trop. Woods 30: 7. 1932. C. Rekoi Standl. Contr. U. S. Nat. Herb. 20: 192. 1919. C. chiapense Standl. l.c. Mario; Santa Maria; lech; leche; leche amarilla (Alta Verapaz).

Wet to dry, mixed forest, most common on plains or foot-hills, 1,200 meters or less; Petén; Alta Verapaz; Izabal; Chiquimula; Jutiapa; Santa Rosa; Escuintla; Guatemala; Chimaltenango; Sololá; Suchitepéquez; Retalhuleu; Huehuetenango; doubtless in all the Pacific coast departments. Southern Mexico; British Honduras to El Salvador and Panama.

A tall glabrous tree, frequently 30 meters high or even more, the trunk often a meter in diameter, the crown rather small, spreading, small buttresses sometimes present; bark smooth or slightly fissured, grayish brown, the inner bark light brown, exuding a yellowish latex; branchlets more or less quadrangular or narrowly winged, green; leaves short-petiolate, varying from lance-oblong to elliptic or obovate, mostly 6-10 cm. long on fertile branches but on sterile branches often 15-20 cm. long, lustrous, usually subacute or short-acuminate, acute at the base, the lateral nerves exceedingly numerous and close together, parallel; inflorescences racemose, axillary and terminal, mostly much shorter than the leaves, few-severalflowered, the pedicels $1 \mathrm{~cm}$. long or shorter; sepals orbicular to oblong-elliptic, 4-6 mm. long; petals 1-3 or none, white or yellowish, oblong, 4-6 mm. long; stamens numerous in the staminate flower, fewer in the pistillate flower; style well developed in the pistillate, equaling or longer than the ovary, the stigma peltate, slightly lobate; fruit globose or oval, 1-2 cm. in diameter, pale green, yellowish at maturity.

In El Salvador sometimes called "barillo" and "varillo;" "leche Maria," "bari," "ocú" (Veracruz, Oaxaca); "lechoso" (Oaxaca). This is a well-known tree in Guatemala as well as in many other parts of Central America, and it is an important timber tree of Guatemala, especially in the Pacific foothills. It is known generally by the name "Mario," and the wood often is advertised for sale in 
the newspapers under this name. The term is said to have no relation with the Spanish name Maria, although in some parts of its range the people have added, more or less as a matter of course, the term "Santa" to the feminine form of the name. Mario is believed to be a term of Antillean origin. This species makes an excellent shade tree, and often is planted for the purpose, its dense crown of deep green leaves reminding one of the Mamey. In El Salvador the yellow latex issuing from the trunk is applied to heal or hold the navel of young babies, when the navel does not heal promptly. Heartwood pink to brick-red, sapwood lighter and distinct; luster rather low; hard and heavy or moderately so, the specific gravity $0.55-0.75$, the weight $34-47$ pounds per cubic foot; texture medium, fairly uniform, the grain usually roey. Lumber holds nails and screws firmly. The timber has been utilized for general construction, ship and boat building, shingles, furniture, and many other purposes in which attractive strong durable material is needed. Small quantities have been exported from tropical America to the United States and Europe. In Central America the wood is valued for fuel, because it burns slowly and for a long time. It is used in some areas for railroad ties. This species has been reported from Guatemala as C. Calaba Jacq.

\section{GLUSIA L.}

Glabrous trees or shrubs, often epiphytic and sometimes strangling their hosts by their epiphytic roots, sometimes woody vines, the sap yellow, viscid, resinous, turning black when dried, dioecious or polygamodioecious; leaves opposite, usually coriaceous, usually with numerous parallel lateral nerves; inflorescences more or less ternately branched, rarely 1-flowered, articulate at the nodes; flowers small or large, unisexual or rarely perfect; bractlets often numerous decussate pairs below the flower and resembling sepals; sepals 4-6, rounded; petals 4-10, free or somewhat connate at the base; stamens usually numerous in the staminate flower, free or connate, variable in form, number, and dehiscence, often accompanied by staminodia, usually covered with a viscid resinous sap; pistillate flower with variously formed staminodia; ovary 4-15-celled, with as many sessile or subsessile, radiate stigmas; ovules anatropous, numerous, arillate, fruit a thick-walled, leathery or fleshy capsule, septicidally dehiscent.

Species about 145, in tropical America, 2 species in New Caledonia and 1 in Madagascar. Several additional ones are found in southern Central America. It is difficult to present a satisfactory account of the Guatemalan species. Although many specimens are available, not all are in proper condition for study, and there is complete material of few species. To make matters worse, while some 
of the species seem to be very uniform in all their characters, others are highly variable and inconstant.

Petioles very short, thick, deeply canaliculate, usually marginate for most or all their length, mostly $6-10 \mathrm{~mm}$. broad; leaves thick-coriaceous, rounded at the apex.

Leaf blades broadest at or near the middle. . C. belizensis.

Leaf blades broadest above the middle.

Pistillate inflorescence usually several-many-flowered and long-pedunculate.

C. conferta.

Pistillate inflorescence usually 3-9-flowered, short-pedunculate or sessile.

Leaves mostly less than 1.5 times as long as broad, very thick, the nerves scarcely prominent beneath....................... rosea.

Leaves usually twice as long as broad or longer, thinner, the nerves very prominent beneath.

Peduncle bearing at the middle a pair of reduced leaves $3-4 \mathrm{~cm}$. long; staminate flowers $9-15 \ldots \ldots \ldots \ldots \ldots \ldots$. lusoria.

Peduncle bearing 2 greatly reduced bracts, these not leaf-like.

Pistillate inflorescences about 9-flowered............. conferta. Pistillate inflorescences 1-5-flowered.

Capsules about $3 \mathrm{~cm}$. long; anthers shorter than the filaments.

C. Massoniana.

Capsules $2 \mathrm{~cm}$. long or shorter; anthers much longer than the short filaments.............................. Salvinii.

Petioles usually elongate, rarely short, slender, not conspicuously canaliculate, less and often much less than $5 \mathrm{~mm}$. broad; leaves relatively thin, flexible, rounded to acute at the apex.

Leaves acute or subacute.

Leaves mostly elliptic or oblong-elliptic, sometimes narrower, broadest at or near the middle, mostly acute at the base............ quadrangula.

Leaves mostly oblanceolate or oblong-oblanceolate, sometimes broader, broadest well above the middle, long-attenuate to the base.

Leaves very obtuse or rounded at the apex.

C. guatemalensis.

Leaves all or mostly $12-19 \mathrm{~cm}$. long.

Capsule as much as $12 \mathrm{~cm}$. long; leaves elliptic-oblong to narrowly cuneate-

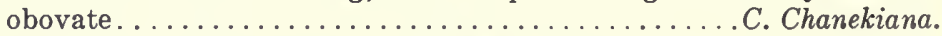

Capsule much smaller, mostly $4 \mathrm{~cm}$. long or shorter.

Leaves broadly cuneate-obovate, $5.5-10.5 \mathrm{~cm}$. wide, broadly rounded or almost truncate at the apex................. suborbicularis.

Leaves oblong-oblanceolate, $4.5-7.5 \mathrm{~cm}$. wide, obtuse or narrowly rounded at the apex......................................

Leaves mostly 5-8 cm. long (occasionally in C. flava to $14 \mathrm{~cm}$.).

Inner sepals about $4 \mathrm{~mm}$. long; leaves when dried thin......... Gentlei.

Inner sepals mostly $6 \mathrm{~mm}$. long or even longer; leaves when dried rather thick and stiff ................................... flava.

Clusia belizensis Standl. Carnegie Inst. Wash. Publ. 461: 72. 1935. 
Known only from the type, W. A. Schipp 1242, collected at Camp 33, Petén, on the British Honduras boundary, 870 meters.

A glabrous tree 9 meters high, the trunk $30 \mathrm{~cm}$. in diameter, the internodes short; petioles 8-10 $\mathrm{mm}$. long, very broad, deeply canaliculate and marginate; leaf blades mostly oblong or elliptic, broadest at or near the middle, 8-14 cm. long, 4-7 $\mathrm{cm}$. wide, rounded at the apex, acute at the base, rigid-coriaceous, the lateral nerves very numerous and close together, ascending at an angle of 45 degrees; pistillate flowers solitary, on a very short thick peduncle; bractlets 2 , broadly rounded, $8 \mathrm{~mm}$. long; sepals 4 , ovate-rounded, broadly rounded at the apex, the inner ones $15-17 \mathrm{~mm}$. long.

Known only from incomplete and somewhat imperfect material, but apparently a distinct and valid species.

Clusia Chanekiana Lundell, Lloydia 2: 102, f. 2. 1939. Chunup (Maya).

Known only from the type, British Honduras, on tree in advanced forest, Valentín, El Cayo District, C. L. Lundell 6366.

An epiphytic shrub 4 meters high, the branches pendent from the weight of the fruits; leaves coriaceous, the stout petioles $1.5-2.5 \mathrm{~cm}$. long, not marginate; leaf blades narrowly cuneate-obovate to elliptic-oblong, $13-22 \mathrm{~cm}$. long, $4.5-9 \mathrm{~cm}$. wide, narrowly or broadly rounded at the apex, attenuate or cuneate at the base, the lateral nerves 20-26 pairs, ascending at a narrow angle, prominent on both surfaces; peduncles stout, $2-3 \mathrm{~cm}$. long, bearing 1-3 fruits, the thick pedicels $1.5-$ $2.5 \mathrm{~cm}$. long, bearing 4-6 bractlets, 4 of these subtending the calyx, depressedobovate, 3.5-6 mm. long; sepals 4, subequal, broadly ovate, $15 \mathrm{~mm}$. long, rounded at the apex; capsule yellowish white, fleshy, often tinged with rose-red on one side, ellipsoid-oblong, as much as $12 \mathrm{~cm}$. long and $4.5 \mathrm{~cm}$. in diameter, 6-celled; pulp surrounding the seeds orange-red; persistent stigmas at the apex of the fruit 6 , teat-like.

The species is remarkable for its large fruits. The fruits in this genus are mostly large and pulpy; they lose their characteristic form when dried and are so difficult to preserve for the herbarium that they are seldom collected. The leaves are very slow in drying, when herbarium specimens are made, and linger in the press longer than those of almost any other group of dicotyledonous plants.

Glusia conferta Standl. Field Mus. Bot. 22: 91. 1940. Jubub or jubup (Alta Verapaz).

Wet, mixed forest, 1,500 meters or lower; so far as known, endemic; Alta Verapaz; Huehuetenango; Izabal (type from banks of Río Dulce, C. L. Wilson 401).

A glabrous tree, sometimes 9 meters high, of ten epiphytic and sometimes subscandent, the branches very thick; leaves almost sessile, rigid-coriaceous, the petiole scarcely $1 \mathrm{~cm}$. long, broadly winged; leaf blades oblong or cuneate-oblong, 
20-24 cm. long, $9 \mathrm{~cm}$. wide, rounded at the apex, slightly narrowed toward the base, the base broadly cuneate, the costa very thick, the lateral nerves very numerous and slender, divergent at a rather broad angle; pistillate inflorescence terminating a stout peduncle $5 \mathrm{~cm}$. long, this naked, the flowers capitate-congested, about 9 , sessile; bracts broadly ovate, coriaceous, closely appressed, $8 \mathrm{~mm}$. long, obtuse or rounded at the apex; sepals 4, decussate, rounded, thick-coriaceous, mostly broader than long, broadly rounded at the apex; ovary large, subglobose, the style column thick, almost $4 \mathrm{~mm}$. long; stigmas 6 , ovate-oval, $2 \mathrm{~mm}$. long.

There may belong here a sterile specimen collected above Tamahú, Alta Verapaz, in wet forest at 900 meters or more. Its leaves, very lustrous when dry, are as much as $38 \mathrm{~cm}$. long and $16 \mathrm{~cm}$. wide.

Clusia flava Jacq. Enum. Pl. Carib. 34. 1760. C. utilis Blake, Contr. U. S. Nat. Herb. 24: 14, t. 4. 1922 (type from Lago de Izabal, Izabal, S. F. Blake 7859). Manzanita de ratón (fide Aguilar); quiebramuelas; hoja de tortilla (Petén); hubuche (Petén, Maya); memela (Huehuetenango).

Moist or wet, mixed forest, 1,300 meters or lower, mostly at low elevations; Petén; Alta Verapaz; Baja Verapaz; Izabal; Sololá; Sacatepéquez; Huehuetenango. Southern Mexico; British Honduras to Costa Rica and probably farther southward; Jamaica.

A shrub or small tree, usually 9 meters high or less, terrestrial or epiphytic, with rather slender branches; leaves slender-petiolate, mostly cuneate-obovate, generally 5-20 cm. long, sometimes slightly larger, rounded or very obtuse at the apex, cuneate-attenuate at the base, the lateral nerves numerous, very slender, ascending at a very narrow angle, prominent on both surfaces in the dry state; flowers in terminal few-flowered cymes, pink, slender-pedicellate, the pistillate inflorescences mostly 3-5-flowered, the pedicels usually bearing several pairs of bractlets; inner sepals rounded, about $7 \mathrm{~mm}$. long; petals obovate, obtuse, thick and fleshy, $1 \mathrm{~cm}$. long or sometimes larger; stamens numerous; filaments much shorter than the short anthers; ovary 6-12-celled; capsule usually 12-35 mm. long, subtended by the persistent calyx, subglobose, crowned by the conspicuous radiating stigmas; seeds about 6 in each cell, $3.5 \mathrm{~mm}$. long, surrounded by an orange aril.

Called "matapalo" in British Honduras; "chunup," "canchunup" (Yucatan, Maya). This has been reported from Guatemala as $C$. minor L. and C. parvicapsula Vesque. The latter is a Mexican species, perhaps not distinct from C. flava. In Izabal the yellow latex is placed on cotton which is applied to cavities in the teeth to relieve toothache. The same vernacular name, "quiebramuelas," and the same use for the plant, are reported also from Honduras. A chemical examination of the latex might be well worth while. In the Yucatan peninsula the latex of this and other species is sometimes used to adulterate chicle. It is reported that the bark is employed for making pails or similar containers for liquids. The wood 
is not used except possibly for fuel and fence posts. In this genus the heartwood is brownish, often with a tinge of pink, of medium luster, rather light but firm to moderately heavy and hard; texture medium to coarse, straight-grained, easy to work; probably not very resistant to decay.

Clusia Gentlei Lundell, Contr. Univ. Mich. Herb. 6: 48. 1941. Matapalo.

Known only from the type, Stann Creek Valley, Stann Creek District, British Honduras, P. H. Gentle 3512.

An epiphytic shrub, the branches slender, ferruginous, the epidermis, as in other species, exfoliating in small pieces that often shrivel and resemble coarse hairs; petioles 3-6 mm. long; leaf blades thin, almost membranaceous when dried, oblanceolate to narrowly cuneate-obovate, $4-10 \mathrm{~cm}$. long, rounded at the apex, narrowly attenuate to the base, the lateral nerves about 15 pairs, ascending at a very narrow angle, prominulous; pistillate flowers sessile, the cymes with 9 or fewer flowers, the bracts $2 \mathrm{~mm}$. long, triangular-ovate; sepals ovate-orbicular, the inner ones $4 \mathrm{~mm}$. long; petals ovate-orbicular, $4 \mathrm{~mm}$. long; ovary 4 -celled.

Clusia guatemalensis Hemsl. Diagn. Pl. Mex. 1: 2. 1878. C. mexicana Vesque, Epharm. 3: 9, tt. 24, 25. 1892. Matapalo; manzana rosa de mico (fide Aguilar); palma rosa (San Marcos); lima real (San Marcos).

Mostly in wet, mixed forest, 300-2,000 meters; Alta Verapaz; Zacapa; Chiquimula; Jalapa; Santa Rosa; Escuintla; Suchitepéquez; Guatemala; Sacatepéquez (type from Barranco Hondo, Volcán de Fuego, Salvin); Chimaltenango; Quezaltenango; San Marcos. Southern Mexico; El Salvador.

A shrub or a small tree, usually 9 meters high or less, terrestrial or more of ten epiphytic; leaves thin, on rather long, slender petioles, variable in form but mostly oblanceolate to oblong-obovate and 8-16 $\mathrm{cm}$. long, acute to obtuse but always more or less pointed at the apex, cuneate to cuneately long-attenuate to the base, the lateral nerves numerous, prominulous, ascending at an angle of 45 degrees or less; staminate flowers creamy or pinkish white, $2.5-3 \mathrm{~cm}$. broad, in 3-12-flowered cymes, pedicellate, the bractlets triangular, acute, 2-4 $\mathrm{mm}$. long; sepals suborbicular, the inner ones $7 \mathrm{~mm}$. long; filaments shorter than the anthers; fruits usually solitary and pendent, sometimes 3 , subglobose, $2-4.5 \mathrm{~cm}$. long, pale green tinged with red, about 8-celled, the persistent sepals as much as $11 \mathrm{~mm}$. long.

Known in El Salvador by the names "icaco montés" and "manzana montés."

Clusia Lundellii Standl. Carnegie Inst. Wash. Publ. 461: 72. 1935. Matapalo. 
Wet, mixed forest, chiefly at or little above sea level; Petén (type from Monte Santa Teresa, C. L. Lundell 3072); Alta Verapaz (planted at Cobán); Izabal. Mexico (Tabasco); British Honduras.

A tree of 10 meters, or a large coarse vine climbing to the tops of tall trees; leaves coriaceous, on rather slender petioles $1.5-3 \mathrm{~cm}$. long, narrowly oblong to obovate-oblong or rather narrowly cuneate-obovate, $14-17 \mathrm{~cm}$. long, $4.5-8 \mathrm{~cm}$. wide, narrowly or broadly rounded at the apex, cuneate-attenuate at the base, the lateral nerves numerous, prominent, ascending at a very narrow angle; pistillate flowers terminal, solitary, the peduncles $3-3.5 \mathrm{~cm}$. long; bractlets about 5 pairs, 4-10 mm. long, rounded-ovate; sepals unequal, ovate-rounded, $1-1.5 \mathrm{~cm}$. long, broadly rounded at the apex; capsule oval, $3.5 \mathrm{~cm}$. long, about 5-celled.

Clusia lusoria Standl. \& Steyerm. Field Mus. Bot. 23: 63. 1944. Lechemaria (probably a corruption of leche amarilla).

Moist or wet, mixed forest, 1,700-2,500 meters; endemic; Zacapa; Chiquimula (type from middle slopes of Montaña Norte to El Jutal, Cerro Brujo, southeast of Concepción de las Minas, Steyermark 30987).

A tree of 15-18 meters; leaves on very thick, winged petioles 1-2 cm. long, oblong-obovate to broadly obovate-elliptic, $9-16 \mathrm{~cm}$. long, 4-10 $\mathrm{cm}$. wide, broadly rounded at the apex, cuneate at the base, of ten broadly so, lustrous above, the lateral nerves numerous, divergent at a rather wide angle, prominulous on both surfaces; staminate inflorescence 9-15-flowered, borne on a thick peduncle 5-11 cm. long, this bearing at the middle 2 foliaceous oblong bracts $3-4 \mathrm{~cm}$. long, the flowers sessile or on very short and thick pedicels; bractlets 2 at the base of the calyx, large, suborbicular; sepals suborbicular, unequal, the inner ones $8 \mathrm{~mm}$. long; petals oval, $18 \mathrm{~mm}$. long and $8 \mathrm{~mm}$. wide, greenish white or pale yellow; stamens numerous, the linear anthers 5-6 $\mathrm{mm}$. long, the filaments somewhat shorter.

Clusia Massoniana Lundell, Contr. Univ. Mich. Herb. 4: 17. 1940.

Moist or wet, mixed or pine forest, 1,700 meters or less; Izabal. British Honduras (El Cayo District, C. L. Lundell 6605).

A glabrous tree of 7-17 meters, the trunk as much as $25 \mathrm{~cm}$. in diameter; leaves thick-coriaceous, the petioles $2 \mathrm{~cm}$. long or shorter, very thick, broadly winged; leaf blades obovate or oblong-obovate, 10-19 cm. long, 4-10.5 cm. wide, broadly rounded at the apex, cuneately narrowed to the base, the lateral nerves 18-30 pairs, prominulous on both surfaces; staminate flowers numerous or few, cymose, the cymes pedunculate, the flowers sessile; sepals suborbicular, $7 \mathrm{~mm}$. long; petals greenish white, oblong or obovate-oblong, $1.5 \mathrm{~cm}$. long or less; stamens numerous, the anthers much shorter than the filaments; capsules $3-5$, oval, 2-3 cm. long, as much as $2 \mathrm{~cm}$. in diameter, 5-celled.

This has been reported from British Honduras as C. Salvinii Donn.-Sm., to which it is closely related. More and better material is necessary to determine the validity and characters of the species 
of this group of the genus. It is quite possible that there are more good species than are recognized here.

Clusia quadrangula Bartlett, Proc. Amer. Acad. 43: 55. 1907. Moist or wet, mixed forest, 900 meters or less; Petén; Alta Verapaz; Izabal (type from Livingston, C. C. Deam 56). British Honduras; Honduras.

A large shrub or a tree, commonly 7-9 meters high, most often an epiphytic shrub, the branches rather slender; leaves slender-petiolate, thin when dried, mostly elliptic or oblong-elliptic, $7-12 \mathrm{~cm}$. long, 3-6 cm. wide, acute at each end, the lateral nerves very numerous, prominulous on both surfaces, ascending at an angle of about 45 degrees; staminate cymes few-flowered, shorter than the leaves, the bractlets often as many as 5 pairs, coriaceous, resembling the sepals; sepals ovate-cordate, the inner ones 4-5 $\mathrm{mm}$. long; petals creamy white, twice as long as the sepals; stamens very numerous, the filaments very short or obsolete, much shorter than the anthers; fruit subglobose or oval, $2 \mathrm{~cm}$. long, about 9-celled.

This has been reported from Guatemala and British Honduras as C. mexicana Vesque, from which it is quite distinct. The plants are sometimes epiphytic. On sterile shoots the leaves may be as much as $18 \mathrm{~cm}$. long and $7 \mathrm{~cm}$. wide.

\section{Clusia rosea Jacq. Enum. Pl. Carib. 34. 1760.}

Moist forest, 900 meters or less; Petén; Alta Verapaz; Suchitepéquez. Southern Mexico; British Honduras; Costa Rica; Panama. West Indies; northern South America.

A glabrous tree or an epiphytic shrub, commonly 10-18 meters high; leaves thick-coriaceous, on very short, broad, winged petioles, rounded-obovate, $7-15 \mathrm{~cm}$. long and almost as wide, broadly rounded at the apex, somewhat cuneately narrowed to the base, the lateral nerves numerous, prominulous, ascending at an angle of about 45 degrees; cymes few-flowered, the branches and pedicels very thick; bractlets 2 at the base of the calyx; sepals 4 , coriaceous, the inner ones as much as $1.5 \mathrm{~cm}$. long; petals 6 , rosy white and waxy; capsule 8-12-celled, subglobose, 5-6 cm. in diameter.

In Costa Rica this and related species are known as "copey," and in the West Indies as "cupey." This term is believed to be of Antillean origin. When fresh, the leaves are very thick, heavy, and succulent. Oviedo relates that during and after the conquest of the West Indies the Spaniards used the leaves in place of scarce paper for sending messages. With a pin or other sharp-pointed instrument, it is possible to write perfectly legible words upon the leaves. They also colored or marked the leaves and used them as playing cards. A deck of such cards must have been rather formidable to shuffle, in spite of the fact that the Spanish deck contains fewer than the customary 52 cards of the deck employed in the United States. 
Clusia Salvinii Donn.-Sm. Bot. Gaz. 35: 1. 1903. C. Schippii Lundell, Contr. Univ. Mich. Herb. 4: 18. 1940 (type from Camp 32, Petén, British Honduras boundary, W. A. Schipp 1275). Matapalo; lengua de venado (fide Aguilar); cerbatana.

Usually in wet, mixed mountain forest, 2,600 meters or lower; Petén; Alta Verapaz; Zacapa; Chiquimula; Jalapa; Guatemala; Sacatepéquez (type from Volcán de Fuego, Osbert Salvin); Chimaltenango; Quiché; Quezaltenango; San Marcos. Southern Mexico; British Honduras; Honduras.

Terrestrial or epiphytic, commonly a tree of 5-9 meters or sometimes larger, sometimes a more or less scandent, epiphytic shrub, the branchlets usually stout; leaves thinly or thickly coriaceous, the petioles $1-3 \mathrm{~cm}$. long, usually thick and winged, rarely slender, oblong-obovate to broadly obovate, $10-18 \mathrm{~cm}$. long, $5-9 \mathrm{~cm}$. broad, rounded at the apex, more or less cuneate at the base, the lateral nerves numerous, prominulous on both surfaces, ascending at an angle of about $45 \mathrm{de}-$ grees; inflorescences mostly 3-5-flowered, the flowers sessile or on short thick pedicels, the bractlets usually 1 pair, similar to the sepals; sepals suborbicular, 7-9 mm. long; stamens $45-50$, the anthers about 3 times as long as the short filaments; capsule globose, about 6-celled, 1.5-1.8 cm. in diameter, the seeds numerous, or most of them abortive.

C. Schippii may be a distinct species, but the material of it now available offers no characters by which it can be distinguished from C. Salvinii.

Clusia suborbicularis Lundell, Phytologia 1:218. 1937. Sello.

Moist or wet forest or thickets, 300 meters or less; Petén; Izabal. British Honduras.

A large or small, glabrous tree, sometimes 17 meters high, with a trunk $25 \mathrm{~cm}$. in diameter; leaves rather thinly coriaceous, the petioles rather slender, not winged, $1.5-2 \mathrm{~cm}$. long; leaf blades cuneate-obovate, usually rather broadly so, $12-16 \mathrm{~cm}$. long, 9-12 cm. wide, broadly rounded or almost truncate at the apex, cuneately narrowed to the base, the lateral nerves $20-25$ pairs, prominulous on both surfaces, ascending at an angle of 45 degrees or less; inflorescences $3-7$-flowered, the pedicels short and thick, the bractlets $3-5$ pairs, crowded, ovate-orbicular, 3-9 $\mathrm{mm}$. long; sepals depressed ovate-orbicular, the inner ones $11 \mathrm{~mm}$. long; stamens exceedingly numerous, the filaments very short, almost obsolete; capsule oval-globose, 5-8celled, $2.5-3.5 \mathrm{~cm}$. long.

The Maya name is reported as "chunup" in British Honduras.

Garcinia Mangostana L. is the Mangosteen, a tree native in the Malay region. Its fruit is considered by some persons to be the most delicious of all tropical fruits. Because of difficulties attending its propagation, and especially because it seems to demand special soil 
and climatic conditions, it never has become common in tropical America, and the total number of trees in Central America is very small, although they have fruited abundantly at various places along the Atlantic coast. A famous tree on the shore of Lake Izabal was leased for some time by the United Fruit Company, to obtain the seeds for planting. Trees have fruited at Quiriguá, and they have done well at Tela, Honduras. The rather small, somewhat depressed fruits are dark purple, about $5-8 \mathrm{~cm}$. in diameter, and contain several large seeds.

\section{HYPERICUM L. St. Johnswort}

Annual or perennial herbs or shrubs, rarely trees, usually glabrous throughout; leaves small, opposite, entire, often gland-dotted, sessile or short-petiolate; flowers 5-4-parted, yellow, often black-punctate, variously arranged; sepals alike or dissimilar; petals usually contorted in bud, of ten persistent in fruit; stamens numerous, free or united in 3 or 5 phalanges opposite the petals; ovary 3-5-carpellate; styles $3-5$, free or more or less united, the stigmas subcapitate; ovules generally numerous; fruit capsular, membranaceous or coriaceous, 1-celled or more or less completely 3-5-celled; endosperm none; embryo straight or curved.

About 300 species, in tropical and temperate regions of both hemispheres, in the tropics found mostly in the mountains. A few other species grown in the mountains of Costa Rica and Panama.

Leaves linear.

Leaves minute, $2.5 \mathrm{~mm}$. long or less, scale-like, closely appressed to the stem.

Leaves much larger, spreading or appressed.

H. aphyllum.

Styles 4 (3?); sepals linear; petals obliquely apiculate and 6-9 $\mathrm{mm}$. long; capsule oblong-cylindric ....................... fasciculatum.

Styles 3; sepals linear-lanceolate to lanceolate-oblong; petals not obliquely apiculate and mostly less than $6 \mathrm{~mm}$. long; capsule ovoid.

Styles much longer than the ovary, about as long as the mature capsule; leaves imbricated, revolute, erect.................. arbuscula.

Styles usually not longer than the ovary and much shorter than the capsule; leaves mostly flat, or sometimes revolute, often spreading or only ascending, not or little imbricated................. uliginosum. Leaves lanceolate to oblong or broader.

Annuals or if more enduring then with long perpendicular roots, never rootstocks.................................. gymnanthum.

Perennials with rootstocks, or shrubs or small trees.

Herbs erect or prostrate, herbaceous or stems suffruticose at the bases.

Flowers solitary at the ends of branches; stamens 16-20; stems slender and weak, usually prostrate or procumbent............... epigeium.

Flowers in corymbs; stamens numerous; stems stout, stiff and erect.

H. formosum.

Shrubs or small trees, the stems woody throughout or nearly so.

Leaves small, all or mostly less than $1 \mathrm{~cm}$. long............. calcicola. 
Leaves larger, mostly $2-6 \mathrm{~cm}$. long.

Sepals about $1 \mathrm{~cm}$. long, long-acuminate; leaves mostly about $7 \mathrm{~mm}$. broad or narrower, crowded on the branches......H. styphelioides.

Sepals $5 \mathrm{~mm}$. long or less, broadly ovate, scarcely acute; leaves mostly 10-20 mm. broad, not crowded............... Steyermarkii.

Hypericum aphyllum Lundell, Am. Midl. Nat. 29: 477. 1943.

Type from Monkey River, Toledo District, in open pine ridge near Jenkins Creek, British Honduras, P. H. Gentle 4175 . Reported also from Florida.

A slender stiff erect annual, $65 \mathrm{~cm}$. high or less, the branches few, erect; leaves opposite, reduced to linear-subulate appressed scales $2.5 \mathrm{~mm}$. long or less; flowers small, scattered along the erect branches, sessile or subsessile; sepals 5, linearsubulate, $2 \mathrm{~mm}$. long; petals linear, yellow, $2.5 \mathrm{~mm}$. long; stamens only 5-6, shorter than the petals, the filaments free; ovules very numerous; styles 3 , free, $1 \mathrm{~mm}$. long; capsule fusiform, 3-4.5 mm. long; seeds minute, oblong, $0.25 \mathrm{~mm}$. long, almost smooth.

Related to the common $H$. gentianoides (L.) BSP. of the United States, but said to differ in seed characters.

Hypericum arbuscula Standl. \& Steyerm. Field Mus. Bot. 23: 63. 1944.

Endemic; Baja Verapaz (type from Patal, John R. Johnston 1812; taken by the same collector "between Patal and Salamá," and the type may have been collected farther southward than Patal, perhaps about Santa Rosa); Quiché.

A low, densely branched shrub about $30 \mathrm{~cm}$. high, the branches very numerous, rather stout, woody throughout, erect or nearly so, very densely leafy; leaves sessile, erect or strongly ascending, imbricate, linear, 1-nerved, 6-9 mm. long, strongly revolute, acute, coriaceous, somewhat lustrous, not punctate; flowers few at the ends of the branches, short-pedicellate, 5-parted; sepals narrowly lance-oblong, acute, nerved, $5 \mathrm{~mm}$. long, epunctate; petals yellow, slightly longer than the sepals, narrowly spatulate, inflexed and cucullate at the apex, not punctate; stamens numerous, distinct, equaling the petals; styles 3 , very slender, as much as $4 \mathrm{~mm}$. long or even longer; capsule ovoid-oblong, $3 \mathrm{~mm}$. long, acute, subtrigonous, 1-celled; seeds few, oblong, terete, brown, almost smooth, $0.8 \mathrm{~mm}$. long.

Hypericum calcicola Standl. \& Steyerm. Field Mus. Bot. 23: 64. 1944.

Known only from the type, on limestone bluffs, common, Dept. Huehuetenango, between Tojquía and Caxín Bluff, summit of Sierra de los Cuchumatanes, 3,700 meters, Steyermark 50160.

A very densely branched shrub, woody throughout, erect and $30-60 \mathrm{~cm}$. high or depressed and spreading, the older branches blackish, the younger ones reddish, 
densely leafy; leaves small, short-petiolate, opposite, subcoriaceous, elliptic or oval, sometimes broadly ovate, 5-10 $\mathrm{mm}$. long, 3-6 mm. wide, obtuse or narrowly rounded at the apex, green above, epunctate, the veins evident and reticulate, paler beneath, sparsely and coarsely punctate, the veins and nerves laxly and rather conspicuously reticulate; flowers solitary at the ends of short branches, on short or elongate pedicels; sepals 4 , ovate-oblong, $2.5 \mathrm{~mm}$. long, pale rose-colored, acute, punctate; petals rose-colored, reflexed, oblong, $7 \mathrm{~mm}$. long, obtuse; stamens about 10 ; styles 3, about $2 \mathrm{~mm}$. long, recurved in anthesis; capsule narrowly ovoid, almost $5 \mathrm{~mm}$. long, pale rose, acute, 3-sulcate, 3-celled; seeds not numerous, narrowly oblong or subfusiform, pale, $1 \mathrm{~mm}$. long.

The species is a very distinct one, and quite unlike any other found in Central America. In general appearance it suggests the densely branched forms of Symphoricarpos microphyllus.

Hypericum epigeium Keller, Bull. Herb. Boiss. II. 8: 183. 1908.

Moist or wet, usually open forest, most frequently in pine forest, sometimes on banks or limestone cliffs, 2,100-3,800 meters; Sacatepéquez (Volcán de Agua, the type J. D. Smith 2147); Chimaltenango; Huehuetenango (Sierra de los Cuchumatanes); Totonicapán; Quezaltenango. Mexico.

A slender perennial herb, rarely somewhat suffrutescent, usually much branched, the stems erect or usually procumbent or prostrate, often forming large colonies, the stems rather densely leafy; leaves usually lax and spreading, thin, sessile, punctate, elliptic to lance-oblong, mostly 1-2 cm. long, sometimes larger, obtuse or subacute at the base; flowers solitary at the ends of the branches, pedicellate; sepals ovate-lanceolate, acute, $3-4.5 \mathrm{~mm}$. long; petals obovate, rounded at the apex, 8-9 mm. long; stamens about 20 , free or nearly so; styles 3 , about $3 \mathrm{~mm}$. long; capsule ovoid, 3-sulcate.

This has been reported from Guatemala as $H$. mexicanum L. Here quite possibly belongs $H$. chamaecaulon Keller (Bull. Herb. Boiss. II. 8: 179. 1908). That name has never been properly published, but is said to pertain to a Guatemalan plant. It appeared in a key published by Keller in the place cited.

\section{Hypericum fasciculatum Lam. Encycl. Meth. 4: 160. 1797.}

Along open stream beds or in shallow sandy-bottomed ponds or in savannas. British Honduras; southeastern United States; West Indies.

Slender shrubs or small trees occasionally to $4.5 \mathrm{~m}$. but usually about $1 \mathrm{~m}$., much branched; leaves opposite or fasciculate, linear, obtuse or mostly glandularapiculate, rounded above, canaliculate below, punctate-glandular, mostly 1-2 cm. long and about $0.1 \mathrm{~cm}$. broad; flowers yellow, solitary on the ends of branches but generally surpassed by new shoots, sessile or nearly so; sepals linear, apiculate, 4-6 mm. long and $1 \mathrm{~mm}$. or less broad, punctate, similar to the leaves but smaller; 
petals cuneate to the base, subtruncate and obliquely apiculate, 6-9 $\mathrm{mm}$. long; capsule 6-7 mm. long, oblong-cylindric, quadrisulcate; styles 4 in our material, about as long as the capsule.

The material from British Honduras differs from that of other regions in having the leaves less conspicuously fasciculate or not at all so, the styles 4 , and the capsule longer and oblong instead of conic-ovoid.

Hypericum formosum HBK. Nov. Gen. \& Sp. 5: 196. 1821.

Moist or wet forest or on open banks, 2,400-2,800 meters; Baja Verapaz (Patal); Quiché (between Chajul and Nebaj); Huehuetenango (Sierra de los Cuchumatanes). Western United States; Mexico.

An erect perennial herb a meter high or less, sometimes suffrutescent below, the stems solitary or clustered, usually branched; leaves sessile, oval or elliptic, 1.5-3 cm. long, rounded or obtuse at the apex, obtuse or subacute at the base, coarsely punctate, paler beneath; flowers bright yellow, corymbose, often numerous, pedicellate; sepals lanceolate, attenuate, $6 \mathrm{~mm}$. long, often punctate; petals oval, 10-12 mm. long; stamens very numerous, free or nearly so; capsule oblongovoid, $8 \mathrm{~mm}$. long, 3-sulcate; styles 3 .

Hypericum gymnanthum Engelm. \& Gray, Bost. Journ. Nat. Hist. 5: 212. 1847.

Moist, open places, or marshes, 1,300-1,400 meters; Alta Verapaz (region of Cobán and Santa Cruz, apparently scarce). Honduras. Widely distributed in the United States.

A slender, erect annual, simple or branched, usually $40 \mathrm{~cm}$. high or less; leaves sessile, thin, ovate or the lowest oval, 1-2 cm. long, sessile and often somewhat amplexicaul, acute or the lower ones obtuse, 3-7-nerved at the base, finely punctate; flowers small, in open terminal cymes, the bracts subulate; sepals lanceolate, $4.5 \mathrm{~mm}$. long, acuminate; petals equaling or slightly longer than the sepals, yellow; capsule 1-celled, $4 \mathrm{~mm}$. long; styles 3 ; stamens 10-12. 1940.

Hypericum Steyermarkii Standl. Field Mus. Bot. 22: 160.

In forest of pine and Abies, 2,500-3,500 meters; Quezaltenango (type from Volcán de Santo Tomás, Steyermark 34760); San Marcos. Mexico (Chiapas).

A branched glabrous shrub or tree 2-6 meters high, the branches brown or brownish; leaves sessile, membranaceous, densely pellucid-punctate, oblong-ovate to lance-oblong, 3-6.5 cm. long, 1-2.2 cm. wide, acute and apiculate, obtusely cuneate at the base, paler beneath; flowers few, very large, terminal, fasciculate, usually 3-4, the pedicels $1-2 \mathrm{~cm}$. long; sepals broadly ovate, 5-6 $\mathrm{mm}$. long, acute, green, black-glandular on the margins; petals deep yellow, $2 \mathrm{~cm}$. long, multilineate, 
obovate, rounded at the apex, sparsely punctate near the apex; stamens numerous, short-connate at the base, in 5 phalanges, half as long as the petals; styles 5 , distinct; capsule ovoid, $14 \mathrm{~mm}$. long, subobtuse, 5-celled; seeds numerous, oblong, 2-2.5 mm. long, pale brown, minutely reticulate.

Hypericum styphelioides A. Rich. Ess. Fl. Cub. 237. 1845. H. terrae-firmae Sprague \& Riley, Kew Bull. 1924: 12. 1924 (type from British Honduras, M. E. Peck 321).

Along stream banks in pine forest, at or little above sea level, British Honduras. Cuba.

A glabrous branched shrub 2 meters high or less, woody throughout, the branches densely leafy; leaves sessile, oblong-lanceolate, ascending, $1.5-2.5 \mathrm{~cm}$. long, acute, narrowed to the base, 5-nerved below, punctate; flowers sessile at the ends of the branches, surrounded by leaves; sepals lanceolate, acuminate, about $1 \mathrm{~cm}$. long, about 10-nerved, epunctate; petals about $2 \mathrm{~cm}$. long, yellow, $6 \mathrm{~mm}$. wide, many-nerved; stamens very numerous, $1 \mathrm{~cm}$. long; ovary 1-celled, the styles 5 and $5 \mathrm{~mm}$. long; capsule $5 \mathrm{~mm}$. long; seeds cylindric, slightly curved, $1 \mathrm{~mm}$. long, punctate-striate.

Sprague and Riley contrasted $H$. terrae-firmae with $H$. styphelioides in several minor characters. These do not hold for the more ample material now at hand, and it is not at all unusual to find a Cuban plant such as this extending to the mainland of Central America, more especially to the Yucatan peninsula.

Hypericum uliginosum HBK. Nov. Gen. \& Sp. 5: 194. 1821. Mil flores (fide Aguilar); retij (Cobán, Quecchí); ruda de monte.

Open fields and hillsides, pine, oak, Cupressus, or Alnus forest, often in wet or marshy places but frequently in dry stony ground, 3,400 meters or less, most frequent at middle elevations; Alta Verapaz; Baja Verapaz; El Progreso; Chiquimula; Zacapa; Jalapa; Jutiapa; Guatemala; Sacatepéquez; Chimaltenango; Sololá; Quiché; Huehuetenango; Totonicapán; Quezaltenango; San Marcos. Mexico; British Honduras; Honduras; El Salvador; Nicaragua; Costa Rica; Panama.

Plants essentially annual but sometimes persisting for more than a year, arising from a perpendicular tap root or from several stout roots, erect, simple or usually branched, mostly $50 \mathrm{~cm}$. high or less; leaves linear or nearly so, mostly 1-2 cm. long, a cute or obtuse and apiculate, narrowed to the sessile base, 1-nerved, puncticulate, paler beneath, spreading or ascending, usually flat but sometimes revolute; flowers usually numerous, subcorymbose along the short or elongate, more or less secund branches, sessile or nearly so; sepals linear-lanceolate, longattenuate, striate, epunctate; petals deep yellow, little longer than the sepals; stamens about 20, free; styles 3; capsule lance-oblong, 5-6 mm. long, acute, 1-celled; seeds very numerous, oval, brownish, scarcely $0.5 \mathrm{~mm}$. long, almost smooth. 
This has been reported from Guatemala as $H$. pratense Cham. \& Schlecht. and as $H$. paucifolium Wats. It is one of the commonest and most widely distributed of Guatemalan plants and is found in almost every kind of habitat except dense, wet forest. It is somewhat weedy by nature and frequently invades cultivated or overgrazed land. In Guatemala it is said to be used sometimes in domestic medicine.

\section{MAMMEA L. Mamey}

Trees with resinous sap; leaves opposite, thick, penninerved; inflorescences axillary, sessile, 1-3-flowered, the flowers polygamous; calyx closed in bud, splitting into 2 valves; petals 4-6; disk none; stamens numerous, the filaments filiform, free, the anthers linear, longitudinally dehiscent; ovary 2-celled, the ovules 2 in each cell, or 4-celled with 1-ovulate cells, the ovules basal, erect; style thick, the stigma large, peltate, 2-4-parted; fruit large, baccate.

Four species, the following one and three others in tropical Africa.

Mammea americana L. Sp. Pl. 512. 1753. Mamey; muc (Quiché).

Native of tropical America, possibly of the West Indies; not native in Central America but grown commonly for its edible fruit; planted rather frequently in Guatemala, chiefly at 1,000 meters or less, and especially frequent along the Pacific foothills and plains; rarely planted as high as 1,500 meters, but not thriving at high elevations. Figure 9.

A medium-sized tree, sometimes $\mathbf{1 5}$ meters high but usually lower, the crown rounded, dense; leaves persistent, somewhat coriaceous, dark green, on petioles 1-1.5 $\mathrm{cm}$. long, broadly elliptic to obovate, usually broadly rounded at the apex, acute or obtuse at the base, $\mathbf{8 - 1 5} \mathrm{cm}$. long or even larger, glabrous, the lateral nerves very numerous, parallel, prominent on both surfaces in the dry state and reticulately connected by elevated veins, the leaves densely pellucid-punctate; flowers part pistillate and part perfect, solitary or clustered, the pedicels $1-1.5 \mathrm{~cm}$. long, the buds globose; sepals semiglobose, concave, thick, 1-1.5 cm. long; petals 4-6, orbicular or oblong, white, obtuse, $1.5-2.5 \mathrm{~cm}$. long; fruit subglobose, apiculate, 10-15 cm. long, the exocarp thick, russet-colored, and rough, the mesocarp rather firm and juicy, yellow or reddish-yellow, sweet; seeds 4 or fewer, the testa rough, fibrous.

Sometimes called "mamey de Santo Domingo" in Yucatan; the Maya name is reported as "chacalhaaz." For some unknown reason, the mamey does not seem to be popular in Central America, and it is rare in many regions. Many northern people, for some obscure reason, consider it one of the best of tropical fruits. It is somewhat like an apricot or a clingstone peach. Some of the fruits 


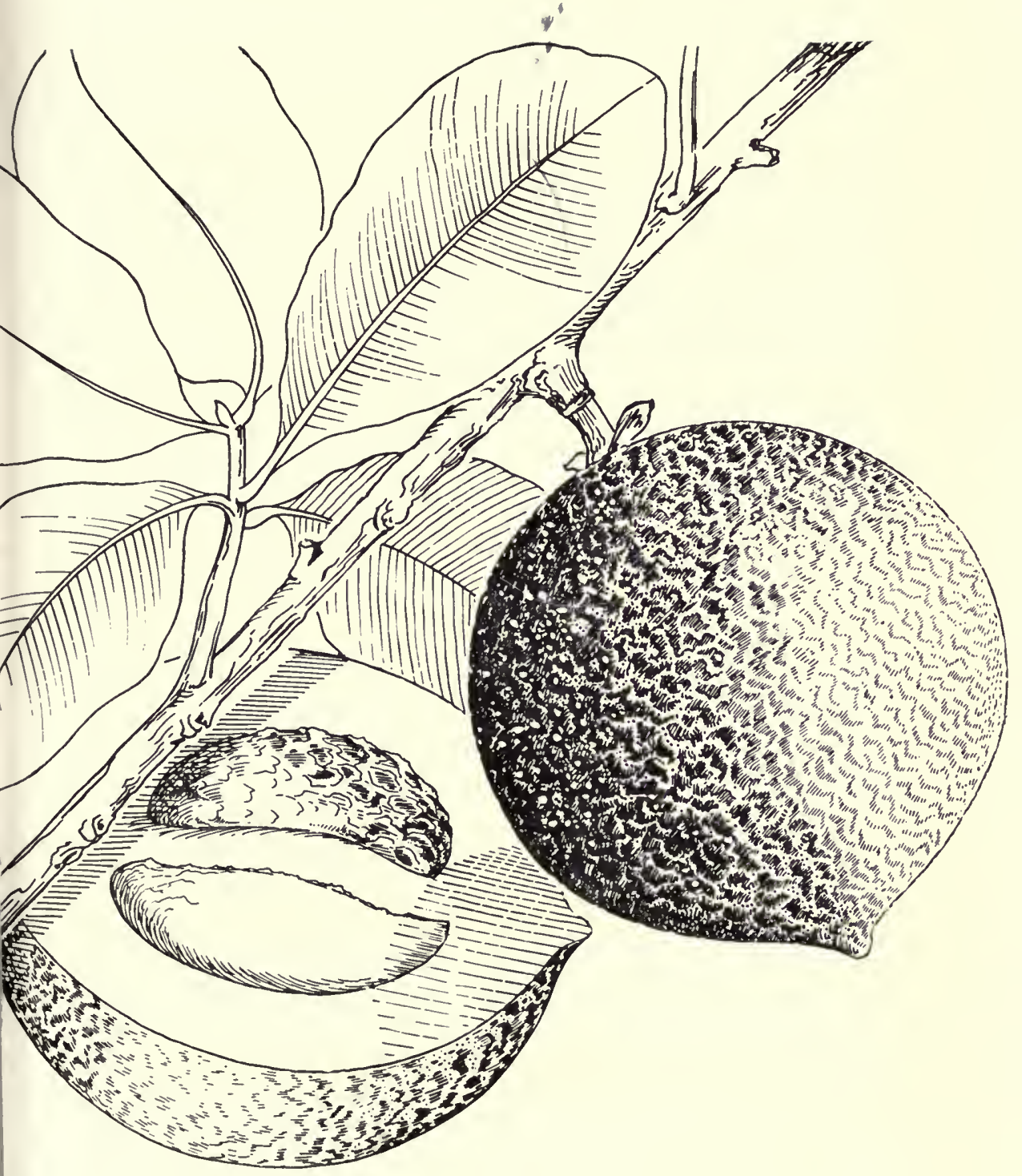

FIG. 9. Mammea americana. Portion of a branch and fruits; reduced. 
are very large, and they are said to weigh rarely as much as 4 kilograms. Some of those in Guatemalan markets are very fine, as large as the largest oranges of the United States. The fruits were observed as plentiful in the markets of the central cities at the end of January, and they are obtainable at other seasons as well. The juice is sometimes used in Guatemala for flavoring aguas gaseosas or soda water. The fruit may be eaten either raw or cooked and sometimes is made into preserves. The flowers are fragrant. The name "mamey" is believed to be of Antillean origin. A caserio of the Department of Retalhuleu is called El Mamey. A tincture made by dissolving the gum of the tree in alcohol is employed externally in Guatemala for killing niguas, redbugs, and other insects. In some regions the timber is employed for fuel, fence posts, and miscellaneous purposes, but in Central America the trees are protected for their fruit. The heartwood is dull reddish or purplish-brown, merging gradually into the lighter sapwood, and it is hard, rather heavy, strong, of medium texture and fairly straight grain, and moderately resistant to decay.

\section{MARILA Swartz}

Trees or shrubs; leaves opposite, petiolate, penninerved, the primary nerves connected by numerous parallel secondary ones; inflorescences axillary, racemose, the flowers perfect or apparently sometimes unisexual; sepals 4-5; petals 4-5; stamens numerous, the filaments linear, free or nearly so, the connective ending in a glandular process; anthers opening by longitudinal slits; ovary 3-5-celled; ovules numerous in each cell, attached to a simple or longitudinally cleft, axile placenta; style simple, the stigma subentire; fruit capsular; seeds comose at each end.

About 20 species, in tropical America. There are two other species in Central America.

Marila verapazensis Donn.-Sm. Bot. Gaz. 47: 253. 1909.

Wet, mixed forest, 350 meters; Alta Verapaz (type from Cubilgüitz, Tuerckheim 8660). British Honduras; Nicaragua; Costa Rica; Panama(?); Colombia.

An almost glabrous tree, sometimes 12 meters high, branching near the ground, the trunk as much as $25 \mathrm{~cm}$. in diameter; leaves short-petiolate, coriaceous, oblong, 16-24 cm. long, 5-8.5 cm. wide, abruptly acuminate, rounded to subacute at the base, punctate beneath and sometimes puberulent on the nerves, the lateral nerves 13-15 pairs, very prominent, divergent at a wide angle; racemes about as long as the leaves, puberulent, many-flowered, the pedicels remote, spreading, the flowers 5-parted, green, odorless; sepals ovate or oval, puberulent, 7-8 mm. long, reflexed in anthesis; petals $9 \mathrm{~mm}$. long, obovate-oblong; anthers very numerous, produced at the apex into a linear appendage; ovary glabrous, the style $5 \mathrm{~mm}$. long. 
Cuatrecasas (An. Inst. Biol. Méx. 20: 95. 1950) has suggested that $M$. verapazensis is a synonym of $M$. laxiflora Rusby, of Bolivia. This has not been verified; however, $M$. laxiflora var. multinervia Cuatr. from the Colombian Choco seems to be the same as the Central American plant.

\section{RHEEDIA L.}

Trees or shrubs, polygamodioecious, the sap yellowish; leaves opposite or verticillate, penninerved, coriaceous, with a marginate pit in the axillary part of the petiole; flowers small, solitary or fasciculate in the leaf axils or at defoliate nodes; sepals 2, more or less united at the base, petals 4, decussate and imbricate; stamens numerous in the staminate flower, free, inserted about and sometimes upon a thick fleshy disk, the anthers subglobose or curved, dehiscent by longitudinal slits; perfect flowers with fewer stamens, these inserted about the base of the disk; ovary superior or partly surrounded by the disk, 3-4-celled, the cells 1-ovulate; stigma peltate-discoid to hemispheric, entire or lobate, subsessile or upon a short style; fruit baccate, crowned by the persistent stigma, the skin coriaceous, smooth or verrucose, 1-celled, containing 1-5 seeds, these enveloped in a pulpy aril.

About 40 species, four in Madagascar, the others in tropical America. Several additional ones are found in southern Central America.

Flower buds just before anthesis $8-12 \mathrm{~mm}$. in diameter; sepals $8-10 \mathrm{~mm}$. long; fruit about $6 \mathrm{~cm}$. long........................ macrantha.

Flower buds before anthesis about $4 \mathrm{~mm}$. in diameter; sepals $4 \mathrm{~mm}$. long or less; fruit usually about $2 \mathrm{~cm}$. long.

Leaves of fertile branches mostly $13-22 \mathrm{~cm}$. long ..........R. intermedia. Leaves of fertile branches mostly $8-10 \mathrm{~cm}$. long.............. edulis.

Rheedia edulis Triana \& Planch. Ann. Sci. Nat. IV. 14: 310. 1860. Mameyito; Arrayán.

Moist or wet forest, 1,200 meters or less, probably planted at higher elevations; Santa Rosa; Guatemala; Sacatepéquez; Quiché. Southern Mexico; British Honduras to El Salvador and Panama. Figure 10.

A small to large, glabrous tree, sometimes 30 meters high, the branchlets green, more or less tetragonous; leaves short-petiolate, coriaceous, often deep red when young, elliptic-oblong or elliptic-lanceolate, those of adult branches mostly 8$10 \mathrm{~cm}$. long, on sterile branches often much larger, obtuse or subacute, acute at the base, somewhat paler beneath, the lateral nerves very numerous, prominent on both surfaces; pedicels usually in dense fascicles at defoliated nodes, the slender pedicels usually $13 \mathrm{~mm}$. long or shorter; sepals oval or rounded, thin, $3-4 \mathrm{~mm}$. long; petals 4 , white, ovate-orbicular, 5-7 mm. long; stamens $25-30$ in the staminate flowers, 10-12 in the perfect flowers; fruit oval, yellow at maturity, usually about $2 \mathrm{~cm}$. long, smooth, rounded at each end. 


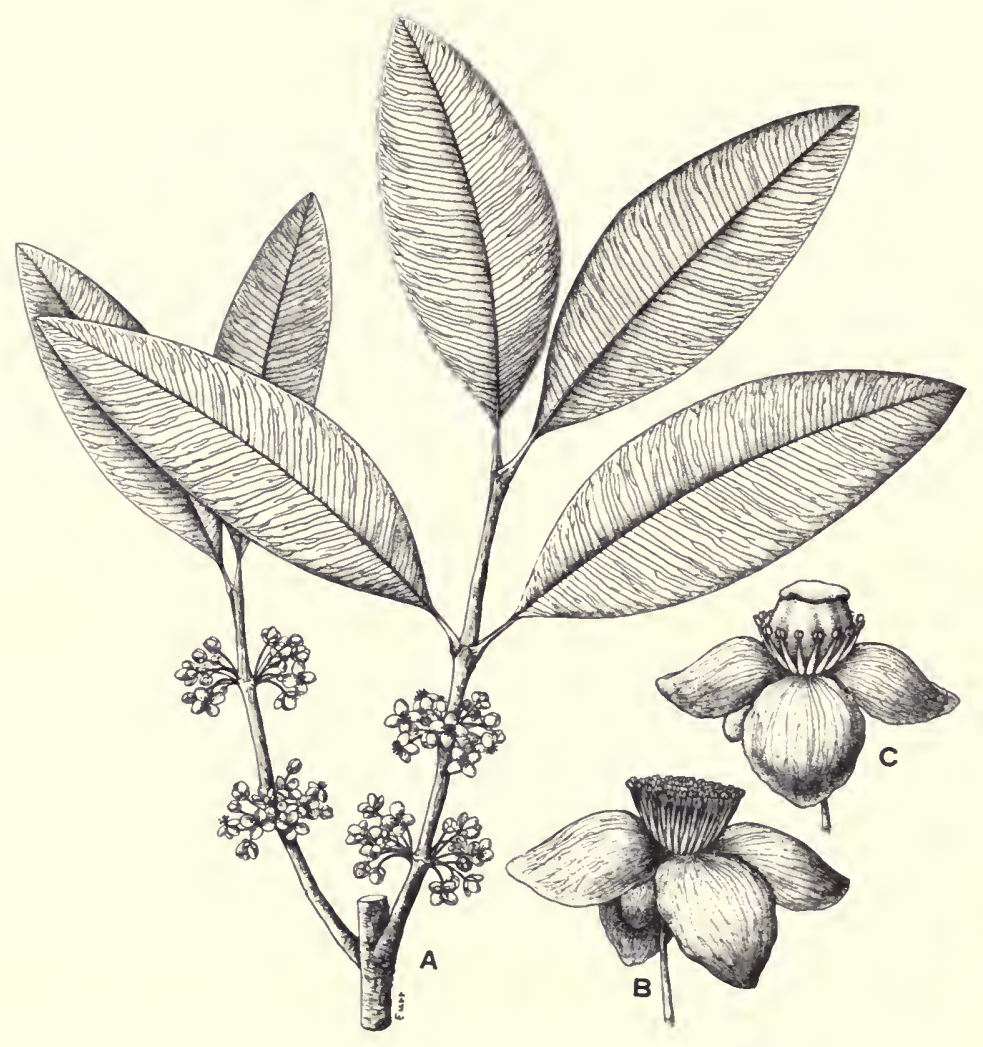

FIC. 10. Rheedia edulis. A, Flowering branch; $\times 1 / 2 . \quad$ B, Staminate flower; $\times 21 / 2$. C, Perfect flower; $\times 2 \frac{1}{2}$. 
Called "chaparrón" in El Salvador. This is a rather common tree on the Pacific plains and foothills and probably grows in all the Pacific coast departments. In this genus the heartwood is dull grayish to pinkish brown, hard, moderately heavy, tough and strong, coarse-textured, with irregular grain; not difficult to work but does not finish very smoothly; of fair durability. The bark is said to be rich in tannin. The timber is used locally for tool handles, general construction and carpentry, fence posts, and railway crossties. The fruit of all the species, probably, is edible.

Rheedia intermedia Pittier, Contr. U. S. Nat. Herb. 13: 454, f. 81. 1912. Leche amarilla; palo bayo (Petén, fide Lundell); crauel (Alta Verapaz); jocomico; jocote de mico (Izabal, fide Blake; probably erroneous names).

Wet, mixed forest, often on limestone, 500 meters or less; Petén; Alta Verapaz (type from Río Lanquín, Tuerckheim 8180); Izabal. British Honduras; Honduras; Nicaragua.

Usually a large glabrous tree, sometimes 18 meters high; leaves coriaceous, short-petiolate, elliptic-oblong or lance-oblong, those of fertile branches mostly 13-22 cm. long, those of sterile branches often larger, acuminate or short-acuminate, often abruptly so, obtuse or cuneate at the base, slightly paler beneath, the lateral nerves very numerous, prominent; flowers fasciculate in the leaf axils or at defoliate nodes, few or numerous, the slender pedicels of ten $2 \mathrm{~cm}$. long; sepals rounded, 2-3 mm. long; petals white, ovate-orbicular, $3.5-4 \mathrm{~mm}$. long; fruit oval, yellow at maturity, $2 \mathrm{~cm}$. long, generally 1-seeded.

Called "waika plum" in British Honduras; "caimito," "caimito de montaña" (Honduras); "sakipa" (Honduras; an Indian name). This has been reported from Guatemala as $R$. macrophylla Planch. \& Triana, var. Benthamiana Vesque, and from British Honduras as R. edulis Triana \& Planch. The bark is described as pale brownish gray with very small, knobby protuberances.

Rheedia macrantha Standl. \& Steyerm. Field Mus. Bot. 23: 65. 1944.

Wet, mixed forest, 900-1,400 meters; often on limestone; endemic; Alta Verapaz (type collected along Río Frío, about $8 \mathrm{~km}$. below Tactic, Standley 90524); Huehuetenango(?).

A medium-sized tree, 9 meters high or more with a trunk $15-20 \mathrm{~cm}$. in diameter, glabrous, the branchlets more or less tetragonous; leaves on thick petioles $1-2 \mathrm{~cm}$. long, coriaceous, elliptic-oblong or lance-oblong, 14-24 cm. long, 4.5-8 cm. wide, acuminate, cuneate or obtuse at the base, lustrous, paler beneath, the lateral nerves very numerous, prominent on both surfaces; flowers large, greenish, fasciculate in the leaf axils or at defoliate nodes, the slender pedicels $2.5-4.5 \mathrm{~cm}$. 
long, the buds 8-10 $\mathrm{mm}$. in diameter; sepals suborbicular, 8-10 $\mathrm{mm}$. long; petals broadly oval or almost orbicular, $8-10 \mathrm{~mm}$. long; stamens numerous in the staminate flower, the filaments stout, dilated toward the base; ovary deeply sulcate vertically, the stigma disciform, thick, $3 \mathrm{~mm}$. broad; fruit ellipsoid, $6 \mathrm{~cm}$. long, $3.5 \mathrm{~cm}$. thick, obtuse at the base, contracted toward the apex.

\section{SYMPHONIA L. f.}

Trees or shrubs with yellowish sap; leaves opposite, penninerved, the petioles without an axillary marginate pit; flowers perfect, in terminal or axillary, mostly umbelliform cymes, rarely solitary; sepals 5, imbricate; petals 5, larger than the sepals, contorted, forming a globose or obovoid bud; disk cupular, extrastaminal, slightly 5-lobate; androecium columnar, split in the upper half into 5 narrow lobes opposite the petals, each lobe bearing 2-4 linear anthers, the anthers dehiscent by lateral slits; ovary 5-celled, the cells 2-8-ovulate; style elongate, cleft into 5 conic radiating lobes at the apex, the stigmas minute, pore-like; fruit baccate, few-seeded.

About 16 species, one in tropical America and Africa, the others in Madagascar.

Symphonia globulifera L. f. Suppl. Pl. 302. 1781. Barillo; leche amarilla; pimientillo.

Wet, often swampy forest, at or little above sea level; Izabal. British Honduras, along the Atlantic coast to Panama; West Indies; South America; tropical Africa.

A large, glabrous tree, sometimes 30 meters high, the trunk sometimes more than a meter in diameter, the bark rough, brownish or darker, the trunk sometimes supported on stilt roots, the crown rounded, with horizontal or often recurved and pendent branches; leaves short-petiolate, coriaceous, lanceolate to lance-oblong or obovate-lanceolate, 6-12 cm. long, obtusely long-acuminate, narrowed to the acute base, the lateral nerves very numerous and slender, prominulous beneath; flowers on pedicels $4-13 \mathrm{~mm}$. long, or in fruit 1-2.5 cm. long; sepals orbicular or broadly ovate, $2-8 \mathrm{~mm}$. long; petals red, orbicular, 11-14 $\mathrm{mm}$. long; fruit globose to ovoid, 3-4 cm. long, dark green at first, brownish or yellowish in age; seeds 1-3, with a thin testa.

Called "waika chewstick," "leche amarillo macho," "wycot," and "corban" in British Honduras. One of the common large trees of the lowland forests on the Atlantic coast of Central America. When growing in the open where they can develop perfectly, the trees often look from a short distance strangely like the American elm (Ulmus americana L.) of the eastern United States. The bark contains a yellowish resin that becomes black and pitch-like upon exposure, and is used in some regions for calking boats. The timber is employed in tropical America for construction, carpentry, crates and boxes, railway crossties, and fuel. Small shipments have been made 
to Europe and North America, mostly for use as veneers for plywood. Heartwood yellowish, grayish, or greenish brown, with a somewhat mealy appearance; sapwood whitish; hard and moderately heavy, the specific gravity $0.65-0.78$; texture coarse, the grain straight or irregular; durability fair.

\section{TOVOMITA Aubl.}

Shrubs or small trees, glabrous or nearly so, dioecious or polygamodioecious; leaves opposite, petiolate, thin, penninerved; flowers small, in terminal paniculate cymes, the pistillate flowers usually fewer and smaller than the staminate ones; sepals $2-4$, if 3 or 4 then the outer ones smaller; petals usually 4 , sometimes $5-8$; stamens numerous, free or somewhat connate; ovary 4-5-celled, with one erect ovule (sometimes 2) in each cell; style very short; fruit a 4-5-valvate capsule, usually with fleshy pericarp; seeds solitary (or two) in the cells; trigonous, surrounded by a fleshy aril.

Perhaps 25 species in tropical America. The genus as here described includes Tovomitopsis Planch. \& Triana.

Tovomita nicaraguensis (Oerst.) L. Wms. Tropical Woods 111: 18. 1959. Chrysochlamys guatemaltecana Donn.-Sm. Bot. Gaz. 13: 26. 1888 (type from Guatemala, Tuerckheim 989). Tovomitopsis guatemaltecana Standl. \& Steyerm. Field Mus. Bot. 23: 66. 1944.

Wet, mixed forests, usually below 1,000 meters; Petén; Alta Verapaz; Izabal; Huehuetenango. British Honduras to Panama.

A glabrous tree 7-15 m. tall, the branchlets terete, stout; leaves oblanceolate to oblong-obovate, acute or short-acuminate, cuneate-attenuate to the base, 10-23 cm. long and 4.5-9 $\mathrm{cm}$. broad, with 10-12 pairs of lateral nerves, very slender, prominulous beneath, petioles $2-2.5 \mathrm{~cm}$. long; panicles terminal, short-pedunculate, about $10 \mathrm{~cm}$. long and often as broad, many-flowered, several times branched, the flowers white, fragrant, long-pedicellate, the buds globose; sepals 4 , in two pairs, the outer pair smaller, $6 \mathrm{~mm}$. or less long; petals 5 , broadly obovate, $8 \mathrm{~mm}$. or less long, resinous striate or punctate; stamens in the pistillate flowers reduced and perhaps some sterile, many, the filaments somewhat dilated toward the base; stigmas 5, cuneate-obovate; ovary 5-celled; fruit obovoid, about $2 \mathrm{~cm}$. long, splitting open at maturity, the valves widely spreading, thick and fleshy.

\section{VISMIA Vandelli}

Trees or shrubs with orange-red sap; pubescence often of a stellate tomentum; leaves opposite, penninerved, often glandular-punctate; flowers paniculate, the branches of the panicle opposite, the pedicels articulate near the base; sepals generally scarious-margined; petals mostly lanate inside; both sepals and petals often with glandular dots and lines; stamens numerous, connate almost half their length into 5 fascicles opposite the petals, alternating with 5 much shorter, obovate or oblong lobes; anthers ovoid or globose, longitudinally dehiscent; ovary 5-celled; 
ovules numerous or rarely few in each cell; styles 5, almost free, the stigmas subcapitate; fruit baccate; seeds cylindric, straight or slightly curved, verrucose.

The genus Vismia is in need of revision. The Central American species have received little attention in recent years and their relation to the species of northern South America is not well understood. It is believed that the specific names used here apply properly to the species concerned, but there may be an older name for each of them.

Species about 15 in tropical America and about five in tropical Africa.

Leaves with coarse ferruginous tomentum on the lower surface, the tomentum not appressed and often of stellate hairs................ camparaguey. Leaves with fine, soft, closely appressed tomentum on the lower surface, of ten brownish at first but in age grayish or white............ mexicana.

Vismia camparaguey Sprague \& Riley, Kew Bull. 1924: 13. 1924. Achotillo; achiotillo; cuxupche (Petén, Maya, fide Lundell); camparaguey; sangre de perro; lengua de chivo (fide Aguilar); camparaguay (Cobán, Quecchí?).

Moist or wet, open forest or brushy plains or hillsides, often in pine forest, frequently in second growth, 1,200 meters or less; Petén; Alta Verapaz; Izabal. Mexico (Chiapas); British Honduras; extending farther southward.

A large shrub or a tree, sometimes 10 meters high with a trunk $30 \mathrm{~cm}$. in diameter, usually much smaller, the branches stellate-tomentose with ferruginous hairs; leaves short-petiolate, lanceolate to ovate-oblong, mostly $15-25 \mathrm{~cm}$. long and 5$9 \mathrm{~cm}$. wide but sometimes much larger on young plants, acuminate or long-acuminate, rarely subobtuse, rounded to shallowly cordate at the base, subcoriaceous, glabrous above, rather laxly ferruginous-tomentulose beneath, the pubescence coarse and not at all appressed, of branched hairs, the lateral nerves about 15 pairs, stout and conspicuous; inflorescences terminal, thyrsiform, many-flowered, of ten $10 \mathrm{~cm}$. long or larger, ferruginous-tomentose throughout, the flowers on pedicels 5-8 $\mathrm{mm}$. long; sepals ovate-lanceolate, obtuse, about $6.5 \mathrm{~mm}$. long, ferruginous-tomentose outside, glabrous within; petals white, oblanceolate, obtuse, $7 \mathrm{~mm}$. long, many-nerved, glabrous outside, villous within; fascicles of stamens with numerous anthers, villous; ovary glabrous; fruit ovoid, $1 \mathrm{~cm}$. long, tipped with the persistent styles, covered below by the persistent sepals.

Known in British Honduras as "Old William," "can't-be-helped," and "yellow sangre." The explanation of one of these names is given as follows: "The wood is poor for building huts, but if nothing else is available this is used, as 'it can't be helped.' "' The wood is pinkish, moderately hard, strong, tough, medium-textured, fairly straightgrained, not difficult to work, not highly durable. Little use is made of it except as fuel. This has been reported from Guatemala as $V$. macrophylla HBK., V. ferruginea HBK., and V. latifolia Choisy. 
Vismia mexicana Schlecht. Linnaea 10: 245. 1836. Camparaguey; camparaguay (Quecchí?); achiotillo.

Moist or wet forest, usually in open pine forest, sometimes in thickets, pastures, or second growth, 900-1,450 meters; Petén; Alta Verapaz; Guatemala(?); Huehuetenango. Southern Mexico; British Honduras; Honduras, and southward.

A shrub or small tree, the slender branches crowned with a close ferruginous tomentum; leaves slender-petiolate, ovate to lance-oblong or ovate-oblong, mostly 12-19 $\mathrm{cm}$. long and 5-7 cm. wide, acute or acuminate, rarely obtuse, at first more or less tomentulose on the upper surface but in age glabrous except along the costa, densely covered beneath with a minute, closely appressed tomentum, this brown or ferruginous at first, becoming pale or whitish in age; panicles small or large, many-flowered, densely ferruginous-tomentose, the flowers pedicellate; sepals about $5 \mathrm{~mm}$. long, densely ferruginous-tomentulose; petals white, $7 \mathrm{~mm}$. long, lineolate; phalanges of stamens bearing as many as 40 anthers, villous; fruit broadly ovoid, 10-12 mm. long, glabrous.

Called "achiotillo" and "guayabón de montaña" in Honduras; "tesuate colorado" (Oaxaca). In Honduras this is often a tree of 9-14 meters, but in Alta Verapaz, where it is abundant, it is usually much lower. The bark is thin, scaly, medium-brown in color, and exudes a small quantity of yellow-brown resin. Around Cobán a decoction of the plant (perhaps a tincture of the resin) is employed as a mouth wash, to relieve toothache, and the leaves are bound on the temples to relieve headache. In Alta Verapaz this species is found at the higher levels, being replaced at lower elevations by $V$. camparaguey. This species has been confused with $V$. guianensis (Aubl.) Pers., from which it seems to be distinct, but it may be synonymous with some of the other South American species.

\section{CISTACEAE}

References: W. Grosser, Cistaceae, Pflanzenreich IV. 193. 1903. E. Janchen, Cistaceae, Nat. Pflanzenfam. ed. 2. 21:289-313, ff. 1925.

Herbs or shrubs; leaves alternate (in Guatemalan species) or opposite, with or without stipules; flowers regular, perfect, solitary, cymose-paniculate or cymoseracemose; sepals 5 or 3 , the outer ones mostly shorter or narrower than the inner; petals 5 , contorted, or 3 and imbricate, in cleistogamous flowers none; stamens numerous, unequal, rarely few, inserted on a hypogynous, usually disk-like receptacle; anthers laterally or subintrorsely dehiscent; ovary 1-celled and with parietal placentae, or incompletely 10-3-celled; ovules numerous or few on each placenta, commonly orthotropous, ascending or recurved; capsule loculicidal, rarely dehiscent only at the apex; seeds with endosperm, the embryo curved; cotyledons foliaceous, linear, subterete, or oblong.

Five genera, of wide distribution, only two of them represented in Central America. 
Petals 3, imbricate in bud; leaves in Guatemalan species linear, strigose. . Lechea. Petals 5, contorted in bud; leaves in Guatemalan species stellate-puberulent or

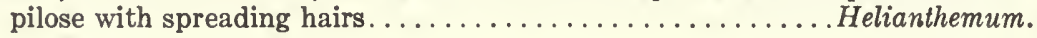

\section{HELIANTHEMUM Adanson}

Plants usually perennial herbs, sometimes suffrutescent at the base, branched, erect or decumbent; flowers small or rather large and showy, yellow, mostly in terminal, simple or bifid racemes or cymes, the lowest often axillary; petals 5 , broad; stamens numerous or rarely few; ovary with 3 placentae or false septa, the ovules numerous; style articulate with the ovary, filiform or subclavate, the stigma capitate or 3-lobate; embryo uncinate.

About 100 species, widely distributed. Only the following are known in Central America.

Stems and leaves pilose with spreading simple hairs.......... chihuahuense. Stems and leaves minutely stellate-tomentulose.

Flowers unequally pedicellate, the pedicels of the petaliferous flowers much longer than those of the cleistogamous flowers, the latter sessile or nearly so.

H. glomeratum.

Flowers all on pedicels of about the same length, the flowers often all petaliferous. H. Pringlei.

Helianthemum chihuahuense Watson, Proc. Am. Acad. 23: 268. 1888.

Dry, open hillsides in the mountains, mostly in pine-oak forest, 1,800-2,500 meters; Jalapa; Chimaltenango; El Quiché; Huehuetenango. Mexico; Honduras.

Perennial from a hard woody root, erect or ascending, $30 \mathrm{~cm}$. high or less, the stems few or numerous, simple or branched, hirsute; cauline leaves oblong-lanceolate or spatulate-lanceolate, mostly 1-2 cm. long and 2-4 mm. wide, acute, sessile, green, pilose with white spreading hairs; leaves of the axillary branches smaller, of ten fasciculate; inflorescences with few-many flowers, the flowers partly petaliferous, and partly cleistogamous, the two kinds on pedicels of equal length; outer sepals linear, the interior ones shorter, ovate, acuminate or mucronate, stellatepuberulent and pilose, in fruit $6 \mathrm{~mm}$. long; petals yellow, twice as long as the sepals; capsule glabrous, ovoid, in the petaliferous flowers $5 \mathrm{~mm}$. long, in the cleistogamous flowers 2.5-3 mm. long; seeds dark ferruginous, subpuberulent.

The plant is not at all common in Guatemala, and usually of only sporadic occurrence.

Helianthemum glomeratum Lagasca ex DC. Prodr. 1: 269. 1824. Cistus glomeratus Lagasca, Gen. \& Sp. Nov. 16. 1816. Halimium glomeratum Grosser, Pflanzenreich IV. 193: 47, f. 11. 1903.

Mostly on open grassy or rocky hillsides, generally in oak or pine forest, sometimes growing on serpentine, 1,500-2,800 meters; Zacapa; 
Jalapa; Chimaltenango; Sololá; Quiché; Huehuetenango; Totonicapán; Quezaltenango; San Marcos. Mexico; Costa Rica.

A slender perennial from a woody, often thick root, the stems rather wiry, of ten numerous, branched or almost simple, usually erect and $40 \mathrm{~cm}$. high or less, covered with a whitish or grayish tomentum of minute stellate hairs; leaves shortpetiolate, lance-oblong or spatulate-lanceolate, $1-2.5 \mathrm{~cm}$. long, $3-9 \mathrm{~mm}$. wide, grayish-tomentulose on both surfaces; petaliferous inflorescences subumbellate and 3-8-flowered, the pedicels $2.5 \mathrm{~cm}$. long or less, the cleistogamous flowers sometimes mixed with the petaliferous ones, or of ten in small dense clusters; outer sepals of the petaliferous flowers linear, half as long as the inner, the latter oval, acuminate, densely stellate-tomentulose, in fruit 7-8 $\mathrm{mm}$. long; inner sepals of the cleistogamous flowers 1-1.5 mm. long; capsule of the petaliferous flowers $6 \mathrm{~mm}$. long, that of the cleistogamous flowers only $2 \mathrm{~mm}$. long, glabrous; seeds brown, lustrous.

All through the pine and oak forests of Chimaltenango, Quiché, and Huehuetenango, especially those regions closely cropped by sheep and cattle, this is one of the most abundant herbaceous plants, and during the dry winter months one may travel many miles without finding any other small plant in flower. Stock evidently does not eat it. The flowers are small for the genus, and not showy.

Helianthemum Pringlei Watson, Proc. Am. Acad. 23: 268. 1888. Halimium Pringlei Grosser, Pflanzenreich IV. 193: 46. 1903.

Reported by Grosser as collected in the mountains of both Huehuetenango and Quezaltenango, Seler 2905, 3286. Mexico.

Plants slender, perennial, erect, $30-50 \mathrm{~cm}$. tall, the stems few or several, mostly simple below, racemosely branched above, minutely stellate-tomentulose; leaves lanceolate or narrowly spatulate, $1.5-2.5 \mathrm{~cm}$. long, 3-5 mm. wide, densely whitish-tomentulose, acute or subobtuse, attenuate to the base, ascending, shortpetiolate or sessile; inflorescence lax, the flowers mostly solitary, the pedicels all long and slender; outer sepals of the petaliferous flower filiform, the inner ones twice as long, oval, in flower $6 \mathrm{~mm}$. long, in fruit 7-8 mm.; petals yellow, twice as long as the sepals; cleistogamous flowers half as large as the petaliferous ones; capsule ovoid, acute, lustrous, in the petaliferous flowers $7 \mathrm{~mm}$. long, in the cleistogamous flowers $3-5 \mathrm{~mm}$. long; seeds ferruginous, smooth.

The species must be rare in Guatemala, for we have collected extensively in the two departments from which it is reported but we have not found it. In general appearance it is substantially different from $H$. glomeratum, especially in its more open inflorescence and taller, more strict stems.

\section{LEGHEA L.}

Reference: Albion R. Hodgdon, Taxonomic study of Lechea, Rhodora 40: 29-69, 87-131. 1938. 
Perennial herbs, rarely suffrutescent at the base, erect or ascending; leaves small, alternate or falsely verticillate, ovate to subulate, without stipules; flowers very small, numerous; sepals 5 , biseriate, the 2 outer ones narrow, the 3 inner broad, imbricate in bud; petals 3 , dark red, usually shorter than the sepals, marcescent; stamens 3-25; ovary short-stipitate, the style very short or none, the 3 stigmas dark red, fimbriate-plumose; placentae of the ovary 3 , broad, each bearing 2 erect subsessile ovules, one on each side of the posterior face; capsule 3-valvate; embryo almost straight or curved in the hard endosperm.

Seventeen species are recognized in the latest monograph, all American, chiefly in eastern United States but ranging southward to West Indies and Honduras.

Exterior sepals equaling or exceeding the interior ones.......... tripetala. Exterior sepals shorter than the interior ones.......... Torreyi var. congesta.

Lechea Torreyi Leggett var. congesta Hodgdon, Rhodora 40: 105. 1938.

In savannas and pine lands. British Honduras (Peck 143). North Carolina to Mississippi and Florida.

Stems simple or branching, 20-40 cm. tall; leaves linear to elliptic, acute, pilose on midrib and margin, sparingly so elsewhere, glabrous above, 5-20 mm. long and to $15 \mathrm{~mm}$. broad; inflorescence a compact panicle, the crowded branches ascending or suberect; inner sepals obovate-elliptic, obtuse, about $2 \mathrm{~mm}$. long, strongly ferruginous-pubescent, outer sepals shorter; seeds 3 .

The species is known in Central America from a single collection.

Lechea tripetala (Mociño \& Sessé) Britton, Bull. Torr. Bot. Club 21: 252. 1894. Helianthemum tripetalum Mociño \& Sessé ex Dunal in DC. Prodr. 1: 284. 1824. L. Skinneri Benth. Bot. Voy. Sulph. 66. 1844 (type collected in Guatemala by Skinner, the exact locality unknown).

Brushy or grassy slopes, in oak and pine forest in the mountains, 1,200-2,100 meters; Zacapa; Jalapa; Guatemala; Sacatapéquez; Chimaltenango; Quiché; Huehuetenango. Mexico; Honduras; Oklahoma, U.S.A.

Plants decumbent or suberect, usually forming dense clumps of many wiry stems, $20 \mathrm{~cm}$. tall or less, sparsely or densely strigose on the leaves and stems; leaves linear, mostly 6-12 $\mathrm{mm}$. long and $1 \mathrm{~mm}$. wide; flowers very small, usually numerous, on pedicels $2-3 \mathrm{~mm}$. long; sepals $2 \mathrm{~mm}$. long, the inner ones ovate, strongly carinate; capsule depressed-globose, $2-2.3 \mathrm{~mm}$. broad; seeds usually 6 , brown, smooth.

The plant is an inconspicuous one of most ordinary appearance, abundant at many places in the pine-oak forests. 


\section{BIXACEAE. Arnotto Family}

Shrubs or trees with yellow or red sap; leaves alternate, simple, long-petiolate, membranaceous, entire, palmate-nerved; stipules in pairs, deciduous; flowers perfect, large, in terminal panicles, the pedicels bearing 5 glands below the calyx; sepals 5 , imbricate, caducous; petals 5 , imbricate, fugacious; stamens indefinite, inserted on a thick receptacle, the anthers oblong, hippocrepiform with the branches united at the back, apically dehiscent by 2 short slits which finally become a single pore; ovary free, 1-celled, with 2 placentae, the ovules numerous; style simple, terminal, the stigma shortly bilobate; capsule bivalvate, densely covered with long and rather soft spines, or of ten unarmed; seeds numerous, obovoid, the coat fleshy, containing a red or yellow sap; embryo axial, straight, the cotyledons broad, the radicle conic-cylindric.

A single genus, with characters of the family.

\section{BIXA L. Arnotto}

An American group, consisting of at least two and perhaps three or more species, only one of which is found in North America. The numerous forms of this genus, at least those referred to $B$. Orellana, are highly variable in the form of the fruit, as well as in the size of the flowers. A critical monograph of the variations, based upon adequate material (which apparently has never been available in any single herbarium), is greatly needed. The generic name is said to be a modification of "bija," the Antillean name of the plant.

Bixa Orellana L. Sp. Pl. 512. 1753. Achiote; achiotillo (form with very small leaves and fruit); chaya; xayau (Quecchí); $о 0 x$ (Chuje); ox (Jacaltenango).

Planted commonly in fincas, chiefly at 1,000 meters or less, occasionally grown at higher elevations; common in wet or dry thickets of the lowlands, and forming extensive, almost pure stands in many places, especially in the Pacific plains; almost or quite absent in some extensive regions; Petén; Alta Verapaz; Baja Verapaz; Izabal (mostly in cultivations); El Progreso; Zacapa (said to be rare); Chiquimula; Jutiapa; Santa Rosa; Escuintla; Sacatepéquez; Quezaltenango; Chimaltenango; Suchitepéquez; Retalhuleu; San Marcos; doubtless found in cultivation in all or most of the departments. Mexico to British Honduras and Panama; West Indies; South America.

A shrub or tree, commonly 2-8 meters high, in Guatemala sometimes 12 meters tall, usually with a dense rounded crown and a short trunk, the bark dark brown, smooth, the inner bark yellow; leaves thin, mostly persistent, on long slender petioles, ovate to broadly ovate or deltoid-ovate, mostly $8-20 \mathrm{~cm}$. long, acuminate or long-acuminate, truncate or rounded at the base and 5-nerved, green and 
glabrous above, paler beneath, usually rather densely but minutely lepidote; panicles rather small, few-many-flowered; sepals 12-14 mm. long, brown-lepidote, obtuse; petals pink or white, about $2.5 \mathrm{~cm}$. long but variable in size, soon falling; capsule ovoid, acute or acutish, commonly $2.5-4.5 \mathrm{~cm}$. long, densely covered with long or short, flexible spines, reddish-brown; seeds numerous, covered with abundant red-orange pulp.

Numerous forms are found in Guatemala, differing in the shape and indument of the fruit and in the size of the petals. The one described above is the most widely dispersed in tropical America, at least in cultivation, and is the one said to yield the largest amount of dye material, although this is by no means certain. The most conspicuous variants of Guatemala and other parts of Central America are the following:

Bixa Orellana var. urucurana (Willd.) Kuntze ex Pilger, Pflanzenreich ed. 2. 21: 315. 1925. B. Urucurana Willd. Enum. Hort. Berol. 565. 1809. Achiote.

The usual wild form in Guatemala, although often seen in cultivation; specimens seen from Petén, Retalhuleu, Jutiapa, Santa Rosa and Escuintla, and probably almost as widely distributed in Guatemala as the typical form. Generally distributed through the range of the species.

Characterized by the form of the fruit, which is globose or depressed-globose, variable in size, and densely covered with long flexible spines.

Bixa Orellana var. leiocarpa (Kuntze) Standl. \& L. Wms. Fieldiana, Bot. 29: 358. 1961. Orellana americana var. leiocarpa Kuntze, Rev. Gen. 45. 1891. Achiote.

Frequent in cultivation in Guatemala; specimens seen from Petén, Santa Rosa, Alta Verapaz, Sololá, and Sacatepéquez, but probably found in all the warmer departments. Widely distributed with the species. British Honduras.

Easily distinguished by the fruit, which is smooth and without bristles.

Bixa is known in British Honduras by the name "atta." The Maya name of Yucatan is listed as "cuxul" and "cuxub" ("ciui" is the dye in small cakes as prepared for use). The name "achiote" (in some regions "achote") is derived from the Nahuatl name, "achiotl." In Guatemala this appears in such place names as Los Achiotes and El Achiotal (an achiote grove or thicket) on the Pacific coast. This tree is one of the best known and most useful ones of all tropical America because of the orange-red dye obtained from the dried seeds, 
or rather from their pulpy covering. Large amounts of it are used in Guatemala, and it is sold in all the markets, either the dried pods with the seeds or more usually the dried and powdered pulp, in the form of small cakes. Achiote is much used through Central America for coloring food, especially rice, also tortillas and other articles. In some regions apparently rice is not considered fit to eat unless it is so colored, but colored rice is not so common in Guatemala. Large amounts of arnotto dye are used in the United States and Europe for coloring butter and cheese, oils, and varnish, the supply coming principally from the West Indies and South America. It gives an orange-yellow color to silk and cotton, but the color is said to be fugitive.

By the Indians of some regions arnotto was formerly much used -and still is, in certain areas-for painting the face and body, partly for ornament and partly to lessen attacks of mosquitoes and other biting insects. At an early date the plant was introduced into the Pacific islands, where the people soon learned to use it for the same purposes. The plant has been carried to most tropical regions of the Old World and has become naturalized in many of them.

The wood is pinkish yellow or whitish, of about the consistency of basswood (Tilia). Some of the Indians used it to obtain fire by friction. A gum obtained from the branches is somewhat similar to gum arabic. The bark contains a strong fiber suitable for cordage.

Being always at hand around the country houses, this plant is much used in domestic medicine. In Guatemala it is esteemed for treating sores and burns, to prevent the formation of scars. It is also a favorite remedy for dysentery, and in Yucatan is used as an antidote for poisoning by the seeds of Jatropha Curcas or Manihot. The specific name, Orellana, was given in honor of Francisco Orellana, associate of Pizarro in the conquest of Peru, and discoverer of the Amazon River.

\section{COCHLOSPERMAGEAE}

Trees, shrubs, or herbs with colored sap; leaves alternate, usually long-petiolate, stipulate, palmately lobate or palmately compound; flowers perfect, large and showy, paniculate or racemose, regular; sepals 5 , imbricate in bud, deciduous; petals 5, yellow, imbricate or subcontorted; stamens numerous, the filaments free, equal or unequal, the anthers linear, 2-celled, opening by terminal, short, often confluent slits; ovary superior, 1-celled and with 3 parietal placentae projecting into the cell, or perfectly 3-celled; ovules numerous; style simple, with a minutely denticulate stigma; fruit a 3-5-valvate capsule; seeds glabrous or covered with long hairs, straight or cochleate-reniform, the endosperm copious; embryo large, the cotyledons broad. 
Three genera, in the tropics of both hemispheres. Two genera are known in America, both represented in Central America.

Trees or shrubs; ovary 1-celled; filaments equal in length........ Cochlospermum. Herbs; ovary perfectly 3 -celled; filaments unequal.............Amoreuxia.

\section{AMOREUXIA Mociño \& Sessé}

Herbs with large tuberous roots; leaves membranaceous, palmately lobate, on very long petioles; flowers large and showy, orange, in few-flowered terminal panicles; sepals 5 , imbricate, deciduous; petals 5 , large, contorted-imbricate; stamens numerous, inserted on an eglandular torus, the filaments very unequal; anthers linear; ovary completely 3 -celled, the placentae axial, many-ovulate; capsule loculicidally 3 -valvate, somewhat inflated, the endocarp membranaceous, separating into valves with the epicarp; seeds obovoid, straight or curved, glabrous or minutely pubescent, the testa osseous.

About six species, ranging from Arizona to Bolivia. Only the following is known from Central America.

Amoreuxia palmatifida Mociño \& Sessé ex DC. Prodr. 2: 638. 1825.

Damp thickets, sometimes in open grassy places, 800 meters or less; Zacapa; Huehuetenango. Mexico; Nicaragua; Arizona, U.S.A.

An erect herb $40-60 \mathrm{~cm}$. tall, the stems pale green, simple or branched, abundantly leafy, puberulent; stipules linear or filiform, deciduous; leaves on slender petioles $6-10 \mathrm{~cm}$. long, the blades $4-8 \mathrm{~cm}$. wide, rounded in outline, cordate at the base, deeply 5-7-lobate, the lobes thin, paler beneath, glabrous or nearly so, obovate, usually rounded at the apex, constricted below, coarsely crenate except near the base; sepals green, $1.5 \mathrm{~cm}$. long, puberulent, ovate-lanceolate to linearlanceolate, acuminate; petals bright orange, about $3 \mathrm{~cm}$. long; capsule ovoid, 3-4 cm. long; seeds turgid, black or dark brown, slightly curved, pubescent.

A showy and handsome plant, well worthy of cultivation. It grows sparingly on brushy plains of the Zacapa Valley, but with foliage only during the wetter months, persisting by its large tuberous roots. In October, 1940, it was growing abundantly in wet places near the oil storage tank in the railroad yards at Zacapa. The Maya name is reported from Yucatan as "zacyab."

\section{COCHLOSPERMUM Kunth}

Reference: S. F. Blake, The American species of Maximilianea (Cochlospermum), Journ. Wash. Acad. Sci. 11: 125-132, f. 1-2. 1921.

Trees or shrubs; leaves palmately lobate or digitately compound; flowers large, yellow, in axillary racemes or terminal panicles; sepals imbricate, deciduous; petals contorted-imbricate; stamens numerous, inserted on an eglandular 
torus, the anthers oblong or linear, sometimes apiculate; placentae of the ovary 3-5, many-ovulate; capsule large, 3-5-valvate, the endocarp membranaceous; seeds cochleate-reniform or spirally twisted, lanate or hirsute, the testa corneous; embryo incurved, the cotyledons ovate.

About 15 species, in tropical Asia, Africa, Australia, and America. Only one species occurs in North America.

Cochlospermum vitifolium Willd. ex Spreng. Syst. 2: 596. 1825. Bombax vitifolium Willd. Enum. Hort. Berol. 2: 720. 1809. C. hisbiscoides Kunth, Syn. Pl. Aequin. 3: 214. 1824. Maximilianea vitifolia Krug \& Urban, Bot. Jahrb. 15: 293. 1892. Tecomasúchil; tecomasuche; pumpunjuche; pumpumjuche; tecomajuche; comasuche; pochote (Petén); tsuyuy (Quecchí); cho (Petén, Maya); pomp, pumpo (Huehuetenango); tecomatillo (Zacapa).

Chiefly on dry brushy hillsides or plains, often in thin coastal forest, frequently in second growth, mostly at 1,000 meters or lower; Petén; Alta Verapaz; Baja Verapaz; Izabal; Zacapa; El Progreso; Jutiapa; Santa Rosa; Escuintla; Suchitepéquez; Retalhuleu; San Marcos; Huehuetenango. Mexico; British Honduras to El Salvador and Panama; northern South America.

A deciduous shrub or tree, sometimes 25 meters high but usually lower, of ten flowering when only 2 meters tall, the crown spreading, not very dense, the bark pinkish-brown, the inner bark yellow, the branchlets thick, dark reddish-brown, at first sparsely pilose; leaves on petioles 10-25 cm. long, usually 5-lobate for onehalf to three-fourths their lengths, $10-30 \mathrm{~cm}$. wide, green and glabrate above, somewhat paler beneath, pilose along the veins or glabrate, membranaceous, the lobes oblong to obovate-oval, acute or obtuse and usually abruptly short-pointed; inflorescences several-flowered, the pedicels densely puberulent, $2-3 \mathrm{~cm}$. long; flowers $8-12 \mathrm{~cm}$. broad, the sepals oblong-ovate to oval, 1-2 cm. long, rounded at the apex; capsule broadly obovoid-oval, $7-8 \mathrm{~cm}$. long, grayish-tomentulose, 5-valvate, umbilicate; seeds reniform, $4.5 \mathrm{~mm}$. broad, densely white-lanate.

Vernacular names reported in adjacent regions are "jicarillo," "berberia," "bombón" (Honduras); "wild cotton" (British Honduras); "coquito" (Chiapas); "madera de pasta" (Yucatan); "chum," "choy," "chimu" (Yucatan, Maya); "pongolote," "palo de cuchara," "apompo" (Oaxaca and Veracruz). The branches are brittle and can be easily broken from the tree. The wood is exceedingly soft and weak, and when green is a soft spongy mass, drying to a loose bundle of fibers. The branches root easily when placed in the ground, and are rarely planted in hedges. The large stamens are said to be used in Central America to adulterate or replace saffron, having considerable superficial resemblance to the stamens of that plant. The tree is employed commonly in domestic medicine of Guatemala in treating kidney and 
liver diseases and to hasten childbirth. The tree is a conspicuous and handsome one when in flower, chiefly during the latter part of the dry season. The large flowers suggest bright yellow roses. The large capsules are soft and somewhat inflated, and can be crushed easily in the hand. The bark contains a tough fiber that is stated to be used sometimes for cordage. The name "tecomasuche" is of Nahuatl origin, signifying "trumpet-flower," a term of no very obvious application.

\section{VIOLACEAE. Violet Family}

Reference: H. Melchior in Engler \& Prantl, Nat. Pflanzenf. ed. 2. 21: 329-377. 1925.

Herbs or shrubs, sometimes trees, rarely scandent; leaves alternate or opposite, simple, entire or variously lobate or dentate; stipules small or foliaceous; flowers usually perfect, very irregular or regular, the inflorescence various, the flowers often solitary in the leaf axils; sepals $\mathbf{5}$, generally persistent, imbricate; petals 5 , imbricate, hypogynous or somewhat perigynous, in some genera very unequal, the lowest petal larger than the others or different in form, of ten spurred at the base; stamens 5, hypogynous or somewhat perigynous; anthers erect, connivent about the ovary and sometimes united, sessile or subsessile, the connective often produced beyond the cells into a membranous appendage, the cells opening by a longitudinal slit; ovary free, sessile, 1-celled, the placentae usually 3, parietal; style simple; ovules usually numerous on each placenta, anatropous; fruit capsular and opening by as many valves as there are placentae, or sometimes baccate; testa of the seed membranaceous or coriaceous, the endosperm usually carnose and copious; embryo axial, usually straight, the cotyledons flat.

Genera about 19 , widely distributed in almost all tropical and temperate regions. Two other genera are known from southern Central America.

Petals unequal, the lowest one different from the others, of ten calcarate at the base.

Sepals produced at the base below the point of attachment; herbs.....Viola. Sepals not produced at the base.

Plants scandent or shrubs; lower petal with a long basal spur longer than the blade of the petal......................... Corynostylis.

Plants not scandent, often herbaceous; lower petal not calcarate, sometimes short-saccate.

Lowest petal conspicuously unguiculate; herbs or shrubs; flowers solitary in the leaf axils or in small, short-pedunculate lateral cymes.

Hybanthus.

Lowest petal sessile or nearly so; trees; flowers in large, long-pedunculate cymes grouped and subumbellate near the ends of the branches.

Orthion.

Petals subequal, not calcarate at the base; trees or shrubs.......... Rinorea. 


\section{CORYNOSTYLIS Martius}

Woody vines; leaves alternate, petiolate, dentate or almost entire; flowers large, very irregular, axiliary, long-pedunculate, the pedicels 2-bracteolate; sepals small, subequal, not produced at the base; lower petal produced at the base into a long spur, the blade small, the other petals smaller; filaments very short, 2 or 4 of the lower"ones shortly villous, calcarate dorsally, the connective produced at the apex into"a membrane; "style clavate, the stigma anterior; fruit capsular, coriaceous, large, "opening by 3 valves, these not elastic; seeds compressed and flat, suborbicular," not"winged," the testa crustaceous, rugose; endosperm thin.

Three or four species, in tropical America. Only the following is known in North America.

Corynostylis arborea (L.) Blake in Standl. Contr. U. S. Nat. Herb. 23: 837. 1923. Viola arborea L. Syst. Nat. ed. 10. 1239. 1759. C. Hybanthus Mart. Nov. Gen. \& Sp. 1:26. 1823.

Wet forest or thickets, at or little above sea level; Petén; Izabal. Southern Mexico; British Honduras; Honduras; Costa Rica; Panama; West Indies; South America.

A woody vine, sometimes 9 meters long, glabrous throughout or nearly so; leaves on rather short petioles, firm-membranaceous, oval to elliptic-ovate, 5$11 \mathrm{~cm}$. long, acute or acuminate, crenulate or almost entire, prominently reticulateveined; flowers large, white, solitary in the upper axils or forming short terminal racemes, the slender pedicels $3-4 \mathrm{~cm}$. long, bracteate above the middle; spur of the corolla sometimes $2.5 \mathrm{~cm}$. long, somewhat twisted, the blade of the spurred petal about $1 \mathrm{~cm}$. long; capsule oval, $5.5 \mathrm{~cm}$. long, $3.5 \mathrm{~cm}$. broad, almost ligneous; seeds very numerous and densely packed, strongly compressed, irregular in outline, brown, lustrous, about $12 \mathrm{~mm}$. in greatest diameter.

Called "monkey apple" in British Honduras. In South America the plant has been used as a remedy for fevers.

\section{HYBANTHUS Jacquin}

Reference: C. V. Morton, The genus Hybanthus in continental North America, Contr. U. S. Nat. Herb. 29: 74-82. 1944.

Shrubs or herbs, sometimes with spinose branches; leaves alternate or rarely opposite; flowers mostly small and inconspicuous but sometimes rather large and showy, the peduncles axillary or in terminal racemes, solitary or fasciculate; sepals somewhat unequal, not produced at the base; lowest petal slightly or much larger than the others, unguiculate, the claw gibbous or subsaccate at the base; anthers subsessile or on distinct filaments, free or connate, the connective produced at the apex into a membrane; style incurved-clavate at the apex, the stigma anterior; capsule elastically 3 -valvate; seeds ovoid-globose, the testa crustaceous.

About 75 species, in the tropics of both hemispheres but most numerous in America. A few other species occur in southern Central America. 
Flowers in cymes; shrub with often spinose branches. . . . . . . . H. yucatanensis.

Flowers solitary or fasciculate in the leaf axils; plants herbaceous or woody, the branches never spinose.

Calyx large, almost $1 \mathrm{~cm}$. long, bearing numerous fleshy green appendages, densely long-pilose......................... Calceolaria.

Calyx much smaller, not appendaged, never long-pilose.

Leaf blades mostly rounded or almost truncate at the base.

Leaves, at least the upper ones, linear; stems glabrous. ...H.oppositifolius. Leaves mostly oblong-ovate; stems puberulent............ Galeottii. Leaf blades all or chiefly acute to attenuate at the base.

Plants annual; at least the lower leaves and branches opposite.

H. attenuatus.

Plants perennial, often woody below; leaves and branches alternate.

Capsule about $4 \mathrm{~mm}$. long; pedicels filiform; leaves mostly obtuse.

H. Thiemei.

Capsule 7-10 mm. long or even larger; pedicels not or scarcely filiform; leaves acute or acuminate.

Plants herbaceous, or suffrutescent at the base, usually less than $40 \mathrm{~cm}$. high; leaves mostly $3-5 \mathrm{~cm}$. long, acute; branches densely puberulent or short-pilose................... verbenaceus.

Plants woody, usually a meter high or even taller; leaves mostly 7$15 \mathrm{~cm}$. long; branches glabrous or nearly so.

Capsule 10-12 mm. long; pedicels minutely puberulent; leaves conspicuously serrate..................... elatus.

Capsule about $7 \mathrm{~mm}$. long; pedicels glabrous; leaves very obscurely crenate-serrulate. ..................... sylvicola.

Hybanthus attenuatus (Humb. \& Bonpl.) G. K. Schulze, Notizbl. Bot. Gart. Berlin 12: 114. 1934. Ionidium attenuatum Humb. \& Bonpl. in Roem. \& Schult. Syst. Veg. 5: 402. 1819. I. riparium HBK. Nov. Gen. \& Sp. 5: 378. 1821. Ionidium oppositifolium and Hybanthus oppositifolius of authors, not Viola oppositifolia L. I. parietariaefolium DC. Prodr. 1: 308. 1824.

In moist soil, in thickets or open ground, often a weed in waste or cultivated places, 1,800 meters or less; Izabal; Alta Verapaz; Zacapa; Jutiapa; Guatemala; Suchitepéquez; Retalhuleu; Quezaltenango; San Marcos; Huehuetenango; Escuintla. Mexico; El Salvador and Honduras to Panama; South America.

An erect annual, commonly 30-50 cm. high but sometimes taller, of ten much branched, the stems puberulent or short-pilose; lower leaves and branches opposite, the upper ones alternate, short-petiolate, elliptic-lanceolate to ovate, $2-7 \mathrm{~cm}$. long, acuminate or long-acuminate, acute at the base, serrate or crenate, inconspicuously scaberulous or puberulent above, sparsely puberulent beneath or almost glabrous; flowers small and inconspicuous, axillary, white, the pedicels slender, often $2 \mathrm{~cm}$. long; sepals lanceolate, $2.5 \mathrm{~mm}$. long; lowest petal $8 \mathrm{~mm}$. long; capsule 3-4 mm. long; seeds ochraceous, subglobose, lustrous. 
A common, often weedy species in the highlands of Central America. The species is quite variable, especially in the leaves, which may be elliptic-lanceolate to ovate and from quite small to fairly large. Called "hierba del rosario" in El Salvador.

Hybanthus Calceolaria (L.) G. K. Schulze, Notizbl. Bot. Gart. Berlin 12: 114. 1934. Viola Calceolaria L. Sp. Pl. ed. 2. 1327. 1763. V. Ipecacuanha L. Mant. Pl. 484. 1771. H. Ipecacuanha Baill. Bot. Médic. 2: 841. 1884.

British Honduras (Big Fall Pine Ridge, Lundell 4230). Mexico (Chiapas and Tabasco); South America.

An erect perennial, usually $40 \mathrm{~cm}$. high or less, simple or branched, herbaceous or somewhat frutescent below, densely or sparsely pilose throughout with long, pale, spreading or subappressed hairs; leaves alternate, short-petiolate or sessile, ovate to lanceolate or oblanceolate-oblong, mostly $2-4 \mathrm{~cm}$. long, obtuse or subacute, narrowed to the base, serrate; peduncles axillary, solitary, shorter than the leaves; sepals about $1 \mathrm{~cm}$. long, lanceolate, acute, densely villous, the margins pectinate-ciliate with green fleshy lobes; petals white or pale blue, the lowest one $2-2.5 \mathrm{~cm}$. long, villous dorsally; capsule ovoid, scarcely equaling the sepals; seeds blackish at maturity.

The plant is well known in Brazil under the names "poaya," "poaya branca," and "purga do campo." There it has been used as a substitute for true ipecac, and has been exported in quantity to Europe for the same purpose.

Hybanthus elatus (Turcz.) Morton, Contr. U. S. Nat. Herb. 29: 80. 1944. Ionidium elatum Turcz. Bull. Soc. Nat. Moscou 36, pt. 1: 556. 1863. Calceolaria glabra Dowell, Bull. Torr. Bot. Club 33: 552, t. 20. 1906. C. brevis Dowell, l.c. H. glaber Standl. Journ. Wash. Acad. Sci. 17: 168. 1927.

Dense, moist or wet, mixed forest, 900-2,000 meters; Escuintla; Santa Rosa; Chimaltenango; Alta Verapaz; Suchitepéquez; Huehuetenango; Quezaltenango; San Marcos. Southern Mexico.

An erect shrub 1-3 meters high, often much branched, the branches rather stiff and slender, glabrous or sparsely puberulent; leaves alternate, short-petiolate, membranaceous, chiefly oblanceolate and $7-15 \mathrm{~cm}$. long, long-acuminate, longattenuate to the base, crenulate, glabrous or nearly so, sometimes finely puberulent; stipules linear-lanceolate, 1-3 $\mathrm{mm}$. long; peduncles axillary, 5-10 $\mathrm{mm}$. long; sepals linear-lanceolate, $4 \mathrm{~mm}$. long, ciliate; petals white, the lowest one $1 \mathrm{~cm}$. long; capsule 10-12 mm. long, ovoid, acute or acuminate, glabrous; seeds ochraceous or brown, subglobose, lustrous, smooth.

Hybanthus Galeottii (Turcz.) Morton, Fieldiana, Bot. 29: 358. 1961. Ionidium Galeottii Turcz. Bull. Soc. Nat. Moscou 27 (2): 339. 
1854. I. occultum Polak. Linnaea 41: 548. 1877 (type from Cerro La Carpintera, Costa Rica). Calceolaria nigricans Dowell, Bull. Torr. Bot. Club 33: 554. 1906 (type from San Pedro Sula, Honduras). H. nigricans Standl. Journ. Wash. Acad. Sci. 17: 169. 1927. H. occultus Standl. l.c. 18: 714. 1937.

Moist forest, 800-1,200 meters; Alta Verapaz; Huehuetenango. Southern Mexico; Honduras; Nicaragua; Costa Rica.

A slender shrub, sometimes a meter high or more, the branches puberulent; leaves alternate, oblong-ovate, 3-7 cm. long, acute or subacute, rounded or truncate at the base, of ten darkening when dried, serrulate, sparsely puberulent or almost glabrous; petioles slender, $4-12 \mathrm{~mm}$. long; flowers white, solitary in the leaf axils, the peduncles slender, mostly $1.5-2 \mathrm{~cm}$. long; sepals lanceolate, $4 \mathrm{~mm}$. long, glabrous; lowest petal $9 \mathrm{~mm}$. long; capsule ovoid, short-rostrate, glabrous.

Hybanthus oppositifolius (L.) Taub. in Engler \& Prantl, Pflanzenfam. 3, pt. 6: 333. 1895. Viola oppositifolia L. Sp. Pl. ed. 2. 1327. 1763. Ionidium angustifolium HBK. Nov. Gen. \& Sp. 5: 377. 1821. H. angustifolius Standl. Journ. Wash. Acad. Sci. 17: 168. 1927.

Reported from Petén and Alta Verapaz (Cubilgüitz). British Honduras; southern Mexico; Honduras.

Plants perennial, erect, herbaceous, mostly $50 \mathrm{~cm}$. high or less, the stems very slender, terete, glabrous; leaves all opposite, the upper ones linear, the lower often linear-lanceolate, 3-7 cm. long, sessile, long-attenuate, rounded at the base, entire or very obscurely serrulate, green above and scaberulous or glabrate, paler beneath and glabrous; flowers on long slender pedicels in the upper axils, white; sepals glabrous, lanceolate, subulate-attenuate; lowest petal about $12 \mathrm{~mm}$. long; capsule $6 \mathrm{~mm}$. long, glabrous; seeds globose, black, very lustrous.

Hybanthus sylvicola Standl. \& Steyerm. Field Mus. Bot. 23: 176. 1944 (type from Guatemala, Wilson 329).

Alta Verapaz. Endemic.

A shrub or small tree of 3-4.5 meters, glabrous throughout, the branches slender, pale green, subterete or obtusely trigonous, woody almost to the ends; stipules narrowly ovate, scarcely $1.5 \mathrm{~mm}$. long, pale; leaves on petioles $3-4 \mathrm{~mm}$. long, oblanceolate or oblong-oblanceolate, $8.5-10 \mathrm{~cm}$. long, $2.5-3.5 \mathrm{~cm}$. wide, acute or short-acuminate, gradually cuneate-attenuate to the base, obsoletely and remotely crenate-serrate or almost entire, paler beneath; flowers subfasciculate from axillary buds, few, the peduncles almost filiform, $5-8 \mathrm{~mm}$. long; sepals glabrous, very unequal, lanceolate or broadly lanceolate, acuminate; lowest petal $8 \mathrm{~mm}$. long, its limb rhombic, the claw almost equaling the limb, the other petals almost equaling the claw; capsule ovoid-globose, $7 \mathrm{~mm}$. long and broad, very obtuse, scarcely rostrate, glabrous.

Hybanthus Thiemei (Donn.-Sm.) Morton, Contr. U. S. Nat. Herb. 29: 81. 1944. Ionidium Thiemei Donn.-Sm. Bot. Gaz. 40: 1 . 
1905 (type from San Pedro Sula, Honduras). Hierba de pesar (Petén, fide Lundell).

Mostly in moist open places, sometimes on open banks, 300 meters or less; Petén; Huehuetenango; Santa Rosa. Southern Mexico; El Salvador; Honduras; Costa Rica; Panama.

Plants erect or suberect, perennial, commonly 6-12 cm. high, simple or sparsely branched, densely leafy, the stems puberulent; leaves alternate, on rather long, very slender petioles, ovate to oblong-elliptic, $2-6 \mathrm{~cm}$. long, very obtuse to subacute, cuneately narrowed at the base, thin, glabrous or nearly so, paler beneath, crenate; peduncles filiform, $1.5-2.5 \mathrm{~cm}$. long; sepals $2.5-3 \mathrm{~mm}$. long; petals white, the lowest $1 \mathrm{~cm}$. long; capsule ovoid, $4 \mathrm{~mm}$. long; seeds minutely pitted, ochraceous.

The Maya name of Yucatan is reported as "xcamuc olal."

Hybanthus verbenaceus (HBK.) Loes. Bull. Herb. Boiss. II. 3: 215. 1903. Ionidium verbenaceum HBK. Nov. Gen. \& Sp. 5: 379, t. 497. 1821. Palomilla (Huehuetenango).

Moist thickets or damp shaded banks, sometimes in pine-oak forest, 1,300-2,000 meters; Alta Verapaz; Jalapa; Jutiapa; Santa Rosa (type from Volcán de Jumaytepeque, Heyde \& Lux 3943); Sacatepéquez; Escuintla; Chimaltenango; Quiché; Huehuetenango. El Salvador.

Plants perennial, erect or decumbent, $30-50 \mathrm{~cm}$. high, often much branched, the stems densely puberulent or short-pilose in two lines; leaves alternate, shortpetiolate, broadly ovate to elliptic, mostly $2-5 \mathrm{~cm}$. long, acute at each end, crenate, minutely hispidulous on both surfaces or finally glabrate, paler beneath; flowers axillary, white, the slender pedicels $10-12 \mathrm{~mm}$. long; sepals lanceolate, acuminate, ciliate, $3 \mathrm{~mm}$. long; lowest petal $6 \mathrm{~mm}$. long; capsule ovoid, glabrous, $1 \mathrm{~cm}$. long, acuminate; seeds subglobose, ochraceous or mottled with light and dark brown.

Hybanthus yucatanensis Millsp. Field Mus. Bot. 1:404. 1898. H. cymosus Bartlett, Proc. Am. Acad. 43: 56. 1907 (type from Gualán, Zacapa, C. C. Deam 385).

In thickets, often in second growth, 600 meters or less; Petén; Alta Verapaz; Zacapa. Yucatan peninsula of Mexico.

A shrub 1.5-2.5 meters high, the branches often short and spinose, conspicuously angulate, the angles wing-like, glabrous, the older branches whitish; leaves alternate, short-petiolate, ovate or oblong-oblanceolate, $2.5-6.5 \mathrm{~cm}$. long, narrowed to an obtuse apex, cuneate or long-attenuate at the base, crenulate, glabrous; flowers small, greenish white, in few-many-flowered axillary cymes, these usually umbelliform, short-pedunculate, the pedicels mostly $3-4 \mathrm{~mm}$. long, glabrous; sepals minute, obtuse; lowest petal $4 \mathrm{~mm}$. long; capsule subglobose, $7 \mathrm{~mm}$. long, glabrous.

The Maya name of Yucatan is "sac-bacel-can," and the name "ta" also is reported. 


\section{ORTHION Standley \& Steyermark}

Glabrous trees, the stipules short and broad, caducous; leaves alternate or congested at the ends of the branches, and subverticillate, chartaceous, narrow, short-petiolate or almost sessile, appressed-serrate or undulate; inflorescences axillary, mostly arising in the upper leaf axils and falsely umbellate, the flowers in lax, many-flowered, much-branched, corymbiform cymes, sessile or short-pedicellate, white, the bracts minute; sepals small, subequal, rounded or oval, rounded to acute at the apex, not produced at the base; lowest petal slightly larger than the others, puberulent outside, sessile, sometimes slightly dilated at the base, retuse at the apex; stamens glabrous, the filaments complanate, broad, connate into a short tube; anthers oval, the broad connective produced at the apex into a short rounded appendage; style stout, subsigmoid-curved; capsule rather large, obtusely trigonous, elastically 3-valvate, thick-coriaceous, obtuse or rounded at the apex; placentae 3 , the ovules numerous, the funicles short; seeds by abortion usually 6 , sometimes 3 , subglobose, smooth.

\section{Only the following not very distinctive species are known.}

Leaves sessile or nearly so, mostly $15-27 \mathrm{~cm}$. long, narrowly rounded at the base. Leaves petiolate, mostly 6-22 cm. long, acute at the base.

O. subsessile.

Leaves lanceolate, long-attenuate at the apex.......... malpighiifolium. Leaves oblanceolate, abruptly acuminate............ oblanceolatum.

Orthion malpighiifolium (Standl.) Standl. \& Steyerm. Field Mus. Bot. 22: 250. 1940. Hybanthus malpighiifolius Standl. Carnegie Inst. Wash. Publ. 461: 73. 1935.

Known only from the type W.A. Schipp 1278 , collected in forest, Camp 32 on the Guatemala (Peten)-British Honduras boundary, 630 meters.

A glabrous tree 10 meters high, the trunk $15 \mathrm{~cm}$. in diameter, the branches slender, green when young; leaves on slender petioles $3-10 \mathrm{~mm}$. long, narrowly lanceolate or oblong-lanceolate, 6-14 cm. long, $1.5-4.5 \mathrm{~cm}$. wide, narrowly longattenuate, acute or attenuate-decurrent at the base, remotely and inconspicuously appressed-serrate, the nerves and veins prominent and reticulate on both surfaces; cymes lax and many-flowered, long-pedunculate, $1.5-2.5 \mathrm{~cm}$. long and broad, the peduncles angulate or complanate, $3-4.5 \mathrm{~cm}$. long, the pedicels $2 \mathrm{~mm}$. long or less; sepals broadly ovate, acute or obtuse, $1 \mathrm{~mm}$. long; lowest petal longer than the others, $2 \mathrm{~mm}$. long, puberulent outside, slightly dilated at the base; immature capsule globose, $4 \mathrm{~mm}$. long, apiculate.

Orthion oblanceolatum Lundell, Lloydia 4: 54. 1941.

Moist or wet, mixed, lowland forest, 300 meters or lower; Petén (type from Guatemala, Mercedes Aguilar H. 497); Alta Verapaz; Izabal; Huehuetenango. Nicaragua.

A glabrous tree 9-15 meters high, the young branches green, terete; leaves chartaceous, on petioles 4-9 $\mathrm{mm}$. long, oblanceolate or oblong-oblanceolate, 7.5- 
$23 \mathrm{~cm}$. long, 2.5-7 cm. wide, rather abruptly acuminate, acute at the base, remotely appressed-serrulate, prominently reticulate-veined; inflorescences crowded at the ends of the branches, long-pedunculate, as much as $13 \mathrm{~cm}$. long, the peduncles and branches complanate, the pedicels in fruit to $6 \mathrm{~mm}$. long, articulate below the middle; sepals unequal, broadly ovate or suborbicular, $2 \mathrm{~mm}$. long, apiculate, minutely erose; petals white, $2.5 \mathrm{~mm}$. long, rounded at the apex; capsule obtusely trigonous, suborbicular, $1.3 \mathrm{~cm}$. long, emarginate; seeds $3-5$, globose, $4 \mathrm{~mm}$. in diameter.

This species possibly is not distinct from the preceding one.

Orthion subsessile (Standl.) Steyerm. \& Standl. Field Mus. Bot. 22: 250. 1940. Hybanthus subsessilis Standl. Carnegie Inst. Wash. Publ. 461: 72. 1935.

Wet, mixed forest, 600 meters or less; Alta Verapaz; Izabal (type from Guatemala, Johnson 1071). British Honduras.

A glabrous tree 6-18 meters high, the trunk as much as $45 \mathrm{~cm}$. in diameter; stipules broadly rounded, mucronate, small, caducous; leaves large, alternate or subopposite, chartaceous, subsessile or on thick petioles $5 \mathrm{~mm}$. long, narrowly oblong or oblanceolate-oblong, 12-34 cm. long, 4-11 cm. wide, acuminate or acute, sometimes obtuse, gradually narrowed to the narrowly rounded or obtuse, often unequal base, remotely undulate-crenate, the veins prominently reticulate on both surfaces; inflorescences cymose, long-pedunculate, subumbellate at the ends of the branches, the peduncles 7-11 cm. long, complanate, straight or slightly incurved, lax and many-flowered, 5-6 $\mathrm{cm}$. long and broad, the pedicels $2 \mathrm{~mm}$. long or less; sepals rounded, pale, scarcely $1 \mathrm{~mm}$. long; lowest petal $2 \mathrm{~mm}$. long, puberulent outside, sessile, scarcely dilated at the base, white, the limb broad and deeply retuse; anthers oval, with a small rounded appendage at the apex; capsule obtusely trigonous, $1 \mathrm{~cm}$. long, green, broadly rounded at the apex, usually 3 -seeded; seeds subglobose, $5 \mathrm{~mm}$. in diameter, ochraceous, smooth.

\section{RINOREA Aublet}

Reference: S. F. Blake, Revision of the American species of $R i$ norea, Contr. U. S. Nat. Herb. 20: 491-518, tt. 31-37. 1924.

Trees or shrubs; leaves alternate or opposite, entire or serrate; flowers small, 5-parted, solitary or usually racemose or paniculate, axillary or terminal; sepals subequal; petals subequal, sessile or short-unguiculate; filaments free or connate, dorsally appendaged or naked, the connective produced beyond the cells; placentae 1-many-ovulate; style straight, the stigma terminal; fruit capsular, the 3 valves elastic or rigid; seeds few, subglobose, glabrous or pubescent, the testa crustaceous or coriaceous.

About 250 species, in the tropics of both hemispheres. A few additional ones occur in southern Central America.

Flowers in small panicles......................... Humelii. Flowers in racemes. 
Leaves broadest above the middle, narrowed to the base, the base itself narrowly rounded; anthers not appendaged............... deflexiflora.

Leaves broadest at the middle, acute at the base; anthers usually appendaged

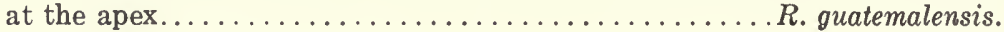

\section{Rinorea deflexiflora Bartlett, Proc. Am. Acad. 43: 56. 1907.}

Wet forest, at or near sea level; Izabal (type from Livingston, C. C. Deam 61). British Honduras.

A shrub or tree, sometimes 6 meters high, the branches slender, sparsely pilosulous or glabrate; leaves opposite or ternate, on petioles $2-5 \mathrm{~mm}$. long, obovate or obovate-oblong, 10-23 cm. long, $4-8 \mathrm{~cm}$. wide, aeuminate, often abruptly so, gradually attenuate to the narrowly rounded or subcordate base, remotely serrulate, firm-membranaceous, puberulent above on the costa, barbate beneath in the axils of the nerves; flowers small, racemose, creamy white, the racemes $4-6 \mathrm{~cm}$. long, the pedicels 4-6 mm. long; sepals ovate or oblong-ovate, 1.8-2.5 mm. long, ciliolate; petals oblong-ovate, $4.2-4.8 \mathrm{~mm}$. long, obtuse; anthers not appendaged; capsule 1.5-2 cm. long, glabrous.

\section{Called "wild coffee" in British Honduras.}

Rinorea guatemalensis (Wats.) Bartlett, Proc. Am. Acad. 43: 56. 1907. Alsodeia guatemalensis Wats. Proc. Am. Acad. 21: 458. 1886. Cuolcuol (Alta Verapaz).

Mostly in wet, mixed forest, sometimes in wet thickets or second growth, often on limestone, 500 meters or less; Petén; Alta Verapaz; Izabal (type from Río Chocón, Sereno Watson 15). Mexico; British Honduras; El Salvador; Honduras.

A shrub or small tree, 10 meters high or less, the bark very thin, flaking off irregularly, the branchlets densely puberulent at first; leaves opposite, on petioles 4-9 mm. long, mostly elliptic, sometimes oval or elliptic-oblong, 7-15 cm. long, 2.5-6 cm. wide, acute or short-acuminate, acute at the base, rather thick, subentire, sparsely strigose or pilosulous beneath along the costa; racemes $3-6.5 \mathrm{~cm}$. long, densely pilosulous or puberulent, the pedicels $2-4 \mathrm{~mm}$. long; sepals ovate or deltoid-ovate, 1-1.5 mm. long, acute or subacute, ciliolate; petals lance-ovate, $5.5 \mathrm{~mm}$. long, cream-colored; anthers bearing 1-2 cusps at the apex or unappendaged; ovary densely pilosulous; capsule puberulent, $1.5-2 \mathrm{~cm}$. long; seeds globose, $6 \mathrm{~mm}$. in diameter, fuscous, sparsely puberulent.

Known in British Honduras as "cafecillo" or "wild coffee;" "Costarrica," "frutillo" (Oaxaca). The sapwood is cream-colored, the heartwood thin, pinkish-brown.

\section{Rinorea Hummelii Sprague, Kew Bull. 307. 1921.}

Moist or wet, mixed forest or thickets, 300 meters or less; Petén; Izabal. Mexico; British Honduras (type from Salt Creek, Hummel). 
A shrub or small tree, 10 meters high or less, the young branchlets minutely pilosulous, the trunk up to $20 \mathrm{~cm}$. in diameter; leaves opposite, on petioles $3-5 \mathrm{~mm}$. long, obovate to elliptic or oblong-elliptic, 6-15 cm. long, $2.5-6 \mathrm{~cm}$. wide, abruptly short-acuminate, acute at the base, obscurely serrulate, chartaceous, glabrous above except for the puberulent costa, glabrous beneath; flowers paniculate, cream-colored, the panicles racemiform, terminal and axillary, $1.5-5 \mathrm{~cm}$. long, puberulent, the lower branches short and few-flowered, the pedicels $2 \mathrm{~mm}$. long; sepals broadly ovate, $1-1.2 \mathrm{~mm}$. long, short-cuspidate or apiculate, ciliolate; petals lanceolate, $4.5 \mathrm{~mm}$. long, obtuse; ovary fulvous-velutinous; capsule minutely brownish-pilosulous or glabrate, $1.5 \mathrm{~cm}$. long.

Called "wild coffee" in British Honduras.

\section{VIOLA L. Violet}

Reference: Wilhelm Becker, Violae mexicanae et Centrali-Americanae, Repert. Sp. Nov. 19: 392. 1924; 20: 1.1924.

Annual or perennial herbs; leaves alternate or often apparently all basal, the stipules usually foliaceous and conspicuous; peduncles axillary, 1-flowered; flowers often dimorphous, the earliest perfect and usually sterile, the later ones small, apetalous, and fertile; sepals subequal, produced at the base below the point of attachment; petals spreading, the lowest usually larger, calcarate or saccate at the base; anthers subsessile, the connective complanate, produced at the apex as a membranaceous appendage, the connective of the two lower anthers usually calcarate dorsally at the base; style usually capitate, clavate, or variously dilated, almost straight, the stigma terminal, or more or less recurved; capsule elastically 3-valvate; seeds ovoid-globose, the testa crustaceous, often lustrous.

A vast genus of perhaps 400 species, generally distributed, chiefly in temperate regions; in tropical America the species are relatively few and confined to mountain regions. One other species is known from southern Central America.

Plants without rootstocks, the main stems elongate, sometimes scandent.

Stipules pinnatifid; peduncles mu ch longer than the leaves........V.tricolor.

Stipules not lobate; peduncles all or mostly shorter than the leaves..V. scandens. Plants with usually thick rootstocks, never scandent, at first acaulescent but usually producing elongate creeping stolons.

Plants cultivated, introduced species............... odorata. Plants native species, not in cultivation.

Leaf blades cordate-ovate, most of them distinctly longer than broad.

Leaf blades mostly rounded-reniform, as broad as long or broader.

V. reptans.

Leaves not at all pointed at the apex; stolons none or poorly developed.

V. Nannei.

Leaves usually conspicuously pointed at the apex; stolons usually well developed.

Leaves glabrous or nearly so; stipules $1.5 \mathrm{~cm}$. long, long-fimbriate.

V. Seleriana.

Leaves usually conspicuously hispidulous beneath; stipules $1 \mathrm{~cm}$. long or shorter, sparsely short-fimbriate or almost entire..V. guatemalensis. 
Viola guatemalensis Becker, Repert. Sp. Nov. 20: 6. 1924. Violeta.

Moist open banks or more often in dense moist forest, often in forests of pine and oak or of Abies or Cupressus, 1,800-4,000 meters; Jalapa; Guatemala; Sacatepéquez (type from Volcán de Agua, 2,850 meters, J. D. Smith 2165); Chimaltenango; Sacatepéquez; Quiché; Quezaltenango; San Marcos; Huehuetenango. Southern Mexico; Costa Rica; Panama.

Plants acaulescent, arising from a thick or slender, fleshy rootstock, developing stolons, these slender, elongate, $10-20 \mathrm{~cm}$. long or more, the stems glabrous or nearly so, the stolons creeping and rooting at the nodes; stipules ovate or lanceolate, $1 \mathrm{~cm}$. long or shorter, acute, fimbriate or subentire, thin, pale green; leaves long-petiolate, rounded-reniform, thin, broadly rounded at the apex and usually abruptly short-pointed, deeply cordate at the base, $2-3.5 \mathrm{~cm}$. long and equally broad or broader, conspicuously crenate, sparsely hispidulous, especially beneath; petioles equaling or exceeding the blades, hispidulous or sometimes quite glabrous; flowers usually longer than the leaves, pale bluish or lavender, $1 \mathrm{~cm}$. long, the peduncles glabrous; sepals ovate or ovate-lanceolate, glabrous, the basal appendages short and rounded; style subclavate toward the apex.

This has been reported from Guatemala as V. Hookeriana HBK. The forma pubescentior Becker (op. cit. 7; type from Todos Santos, Huehuetenango, C.\& E. Seler 2636) is apparently of little or no systematic importance, having longer and more abundant pubescence on the leaf blades, petioles, and peduncles. The species of this group are poorly defined by Becker, and it is uncertain how many of them are really valid.

\section{Viola Nannei Polak. Linnaea 41: 547. 1877. Corazón; violeta.}

Moist, open banks, alpine meadows, often in forest of Alnus, pine and oak, Juniperus, or Cupressus, 1,800-4,000 meters; Zacapa; Jalapa; Guatemala; Sacatepéquez; Chimaltenango; Sololá; Totonicapán; Quiché; Huehuetenango; Quezaltenango; San Marcos. Mexico (Chiapas); Costa Rica; Panama.

Plants low and acaulescent, from a stout or rather slender rootstock, producing sometimes short and poorly developed stolons, or these wholly absent; stipules $1 \mathrm{~cm}$. long or shorter, lanceolate or ovate, acute, remotely long-fimbriate; leaf blades reniform, mostly $2-2.5 \mathrm{~cm}$. long and equally broad, broadly rounded at the apex, deeply cordate at the base, crenate or subentire, hispidulous, at least near the base; flowers rather pale violet, $1 \mathrm{~cm}$. long, the spur short, whitish; sepals ovate, hispidulous, the basal appendages short and rounded.

This has been reported from Guatemala as $V$. Hookeriana HBK. V. Nannei var. glaberrima Becker (Repert. Sp. Nov. 20: 5. 1924; type collected between Zihá and Calel, Huehuetenango, 3,000 meters, 
C. \& E. Seler 2942) is glabrous throughout. Apparently it is without systematic importance, since glabrous and hispidulous leaves may be found on different parts of the same plant.

Viola odorata L. Sp. Pl. 934. 1753. Violeta; sweet violet.

Native of Europe, Asia, and Africa; now cultivated for ornament in all civilized parts of the earth; grown in almost all parts of Guatemala, from sea level to the upper limits of cultivation.

Plants low, perennial from a thick rootstock, producing long slender stolons; leaves on usually very long and slender petioles, cordate-ovate or reniform, crenate, deeply cordate at the base, glabrous or nearly so, rounded to subacute at the apex; stipules ovate-lanceolate, acuminate, fimbriate; flowers fragrant, deep violet, the spur straight, obtuse.

Violets are one of the favorite flowers of Guatemala, and are grown almost anywhere in the country, but they thrive best at middle elevations. The flowers produced in Guatemala and Quezaltenango often are unusually large, with long stems, and they are sold in great bunches in the markets of large cities, as well as in other places. A few plants are to be found in almost any patio in the mountain regions.

Viola reptans Robinson, Proc. Am. Acad. 27: 165. 1892. $V$. Schaffneriana Becker, Repert. Sp. Nov. 20: 2. 1924.

Dry or moist open places or in forest, 1,800-2,500 meters; Chimaltenango; Sololá. Mexico.

Plants acaulescent, from a rather thick, short rootstock, producing elongate stolons, these glabrous or sparsely or densely hispidulous; stipules lanceolate or linear-lanceolate, long-fimbriate; leaves long-petiolate, the blades broadly ovate, obtuse, shallowly cordate at the base, rather thick and firm, crenate, somewhat paler beneath, sparsely or densely hispidulous; flowers equaling or longer than the leaves, violaceous, the spur short and thick; sepals ovate-lanceolate, the basal appendages short, subquadrate.

Viola scandens Willd. ex Roem. \& Schult. Syst. 5: 391. 1819. V. Lindeniana Turcz. Bull. Soc. Nat. Moscou 27, Abth. 2: 336. 1854.

Moist or rather dry thickets and mountain forest, 1,400-2,900 meters; Baja Verapaz; El Progreso; Quiché; Huehuetenango; San Marcos. Southern Mexico; El Salvador; Honduras; Costa Rica; northwestern South America.

Plants scandent, herbaceous or suffrutescent below, forming dense tangles over bushes, often a meter long or even more, the stems glabrous; stipules oblong, remotely dentate-ciliate; leaves slender-petiolate, triangular-ovate or oblong-ovate, 
2-4 cm. long, acute, shallowly cordate at the base, crenate, glabrous; flowers about equaling the leaves, small, the sepals subulate-lanceolate; petals white, the lip striped with lavender, acuminate, the spur very short; anthers long-cuspidate at the apex; capsule globose, glabrous.

\section{Viola Seleriana Becker, Repert. Sp. Nov. 20: 6. 1924.}

Type, above Zacaltenango, Huehuetenango, C. \& E. Seler 3132; San Marcos.

Plants acaulescent, the rhizome rather thick, the stolons none or short and slender; stipules lanceolate, acuminate, $1.5 \mathrm{~cm}$. long, brownish, long-fimbriate; leaves long-petiolate, not exceeding the flowers, the petioles glabrous, the blades broadly reniform, pointed at the apex, deeply cordate at the base, crenate, hispidulous, at least beneath near the base; flowers $1 \mathrm{~cm}$. long, pale violet; sepals narrow, acute; spur of the lowest petal very short and rounded.

This is evidently closely related to $V$. guatemalensis and $V$. Nan$n e i$, and perhaps all are forms of a single species, to be called $V$. Nannei, or more probably $V$. Hookeriana HBK.

\section{Viola tricolor L. Sp. PI. 935. 1753. Pensamiento; pansy.}

Native of Europe, now cultivated for ornament in all civilized parts of the earth; grown commonly in Guatemala in most settled regions.

Plants annual or biennial, glabrous or pubescent, the stems angulate, often branched; stipules large and foliaceous, conspicuous, lyrate-lobate or deeply laciniate; upper leaves oval to lanceolate, $1.5-2.5 \mathrm{~cm}$. long, the lower ones ovate, of ten cordate, crenate-serrate; flowers large and broad, variable in size and in color, yellow, purple, white, or brown, sometimes blue or almost black.

Pansies are much grown at middle and rather high elevations, and at times even in the lowlands. They are common in small private gardens, and often are planted in beds in the parks. Quantities of the flowers are offered for sale in such markets as those of Guatemala and Quezaltenango.

\section{FLACOURTIACEAE}

Trees or shrubs, sometimes armed with spines or thorns; leaves alternate, simple, dentate or entire, generally with pellucid dots or lines; stipules small, deciduous, or none; flowers mostly small, sometimes large, regular, perfect or unisexual; sepals distinct or united below, free from the ovary or sometimes united below with it, imbricate or valvate; petals distinct, often none; stamens definite or numerous; ovary free or more or less inferior, mostly 1-celled (rarely 2-5-celled), the 2-6 placentae parietal; ovules numerous; style simple or divided; fruit baccate or berry-like, sometimes capsular; seeds usually few, often arillate; endosperm carnose, the embryo axial, the cotyledons broad, often cordate. 
About 85 genera, widely dispersed in tropical regions. Several additional genera occur farther south in Central America.

Petals present.

Flowers in spikes or racemes.

Leaves 3-5-nerved; flowers 4-parted; ovary superior. . . . . . . Bartholomaea.

Leaves penninerved; flowers 6-7-parted; ovary half inferior......Homalium.

Flowers neither spicate nor racemose, mostly paniculate or corymbose, sometimes fasciculate or umbellate.

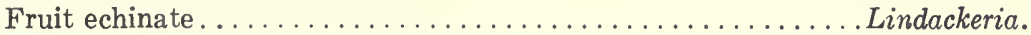

Fruit unarmed.

Fruit with broad, vertical wings; leaves mostly $30-50 \mathrm{~cm}$. long.

Fruit not winged; leaves much smaller.

Carpotroche.

Fruits many-seeded; inflorescences fasciculate or umbellate.....Prockia.

Fruits usually 1-seeded; inflorescences paniculate, cymose or corymbose.

Inflorescences cymose or corymbose; fruits glabrous. . . . . . Hasseltia.

Inflorescences paniculate; fruits tomentose.......Pleuranthodendron.

Petals none.

Sepals valvate.

Flowers in slender, usually much elongate racemes. . . . . . . . . Lunania.

Flowers fasciculate or umbellate.................. Prockia. Sepals imbricate.

Flowers unisexual or polygamous; staminodia none; plants of ten with spinetoothed leaves, or the trunks often armed with branched thorns.

Leaves usually with spine-tipped teeth; fruit $4-5 \mathrm{~cm}$. broad or larger.

Olmediella.

Leaves never with spine-tipped teeth; fruit less than $1 \mathrm{~cm}$. broad . .Xylosma .

Flowers perfect; leaves never spine-toothed; trunk never armed with branched thorns.

Flowers without staminodia .......................

Flowers with staminodia alternating with the stamens.

Style none; stamens $20-40 \ldots \ldots \ldots \ldots \ldots \ldots$. . . . . . . . . . . . . . . . . . . . . . . . . . . . .

Style present; stamens $6-16 \ldots \ldots \ldots \ldots \ldots$ Casearia.

Banara dioica Benth. Journ. Linn. Soc. 5, suppl. 2: 94. 1861.

Mexico (Veracruz) and Honduras. While this genus has not been found in Guatemala or British Honduras the fact that it is found on both sides of these countries indicates that it should be discovered there.

\section{BARTHOLOMAEA Standl. \& Steyerm.}

Dioecious trees or shrubs, the branches slender, terete, flexuous; stipules minute, subulate, deciduous; leaves alternate, small, short-petiolate, 3-5-nerved, sparsely pellucid-punctate, crenate-serrate or undulate-serrate, the pubescence of simple hairs; flowers mostly 4-parted, sometimes 3-parted, unisexual; inflorescence 
spicate, axillary, sometimes branched from near the base, solitary; flowers solitary, bracteate at the base; sepals of the staminate flowers free, minute, suborbicular; petals of the staminate flowers similar to the sepals or sometimes 2-3 times as long; stamens 8-12, inserted on an inconspicuous, minute disc, filaments filiform, glabrous, the anthers minute, didymous; style none, the stigmas usually 4 , short, subulate, ovules 8,2 on each of 4 parietal placentae; capsule small, glabrous, depressed-globose, usually 4 -valvate to the middle; seeds 3-6, subglobose, covered with long, soft hairs, inserted along the middle of the valve near the apex, glabrous within.

The two following species are known. The genus is dedicated to Bartolome de las Casas, Protector of the Indians, builder of the ancient church of Cobán, and one of the most admirable heroes of the Conquest. It was he who first introduced European civilization and Christianity to the Quecchí Indians of Verapaz, and was indeed the author of the very name Verapaz.

Leaves pilosulous beneath; stamens 8; leaves membranaceous, dull....B. mollis. Leaves glabrous beneath or only with tuft in axils of nerves; stamens 8-12; leaves coriaceous, lustrous. ........................... sessiliflora.

Bartholomaea mollis Standl. \& Steyerm. Field Mus. Bot. 22: 252. 1940 .

Wet, mixed forest at sea level, along the Río Dulce, Izabal; endemic; type collected between Livingston and 6 miles up the river, on the north side, Steyermark 39452. Figure 11.

A shrub or small tree, the young branchlets densely spreading-pilosulous; petioles 4-5 mm. long; leaf blades elliptic-oblong to ovate, $4-8 \mathrm{~cm}$. long, 2-3.7 cm. wide, acute or acuminate with obtuse tip, more or less asymmetric at the base, narrowly rounded to acute, remotely undulate-serrate or subentire, remotely and coarsely pellucid-punctate, very minutely puberulent above, slightly paler beneath, pilose with rather short, spreading hairs, especially along the nerves and veins, 3-nerved from the base; staminate spikes almost sessile, very slender, 2.5$7 \mathrm{~cm}$. long, many-flowered, the rachis densely pilosulous; bracts equaling the sepals; sepals suborbicular, $0.6-0.9 \mathrm{~mm}$. long, rounded at the apex, minutely pilosulous outside; petals oval, glabrous, rounded at the apex, 1.2-1.5 $\mathrm{mm}$. long; stamens 8, equaling or slightly longer than the petals; valves of the capsule $2.5 \mathrm{~mm}$. long and 1.5-2 mm. broad, coriaceous; seeds 1-1.5 mm. long, covered with slender hairs $3-4 \mathrm{~mm}$. long.

Bartholomaea sessiliflora (Standl.) Standl. \& Steyerm. Field Mus. Bot. 22: 252. 1940. Lunania sessiliflora Standl. Carnegie Inst. Wash. Publ. 461: 74. 1935. Bartholomaea paniculata Lundell, Wrightia 2: 55.1960 (type from Petén, Guatemala, Lundell 15383).

Moist or wet lowland forests, 300-450 meters; Petén; Alta Verapaz. British Honduras (type Schipp S606). 


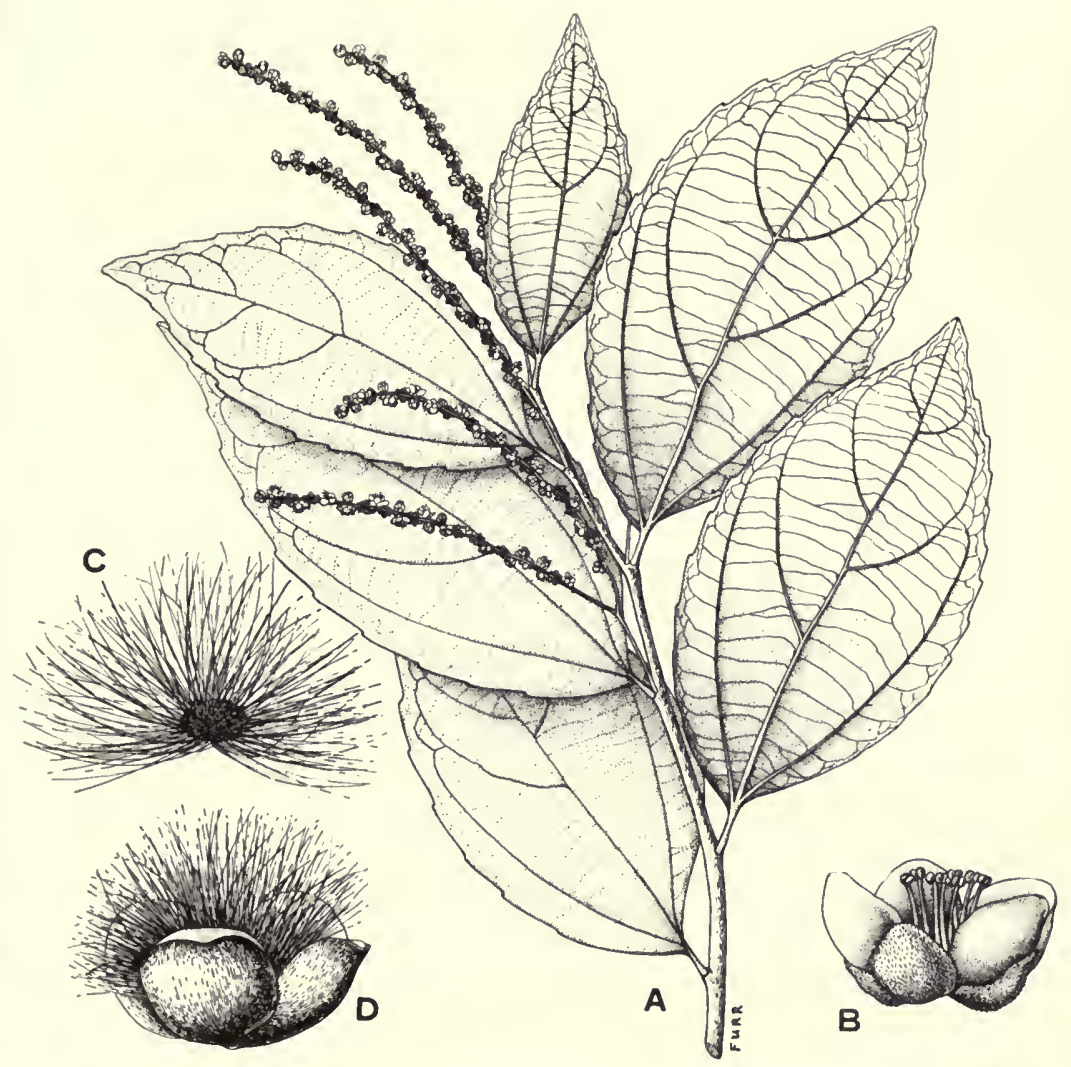

FIG. 11. Bartholomaea mollis. A, Flowering stem; $\times 3 / 4 . \quad$ B, Pistillate flower; $\times 10$. C, Seed, showing attached hairs; $\times 10$. D, Pistillate flower; $\times 10$. 
A glabrous tree to $6 \mathrm{~m}$. high, the trunk to $7.5 \mathrm{~cm}$. in diameter, the slender branches sparsely lenticellate; petioles $4-5 \mathrm{~mm}$. long; leaf blades broadly lanceolate to ovate, $4.5-8.5 \mathrm{~cm}$. long and $2.5-4 \mathrm{~cm}$. broad, acuminate, oblique at the base and rounded on one side, acute on the other, closely serrate, lustrous above, fuscous when dry, dull beneath, 3-5-nerved at the base, with tufts of hair in the axils of the nerves below; staminate spikes $6-8 \mathrm{~cm}$. long; flowers remote, scarcely $1.2 \mathrm{~mm}$. long; bracts lanceolate, acuminate, about $1 \mathrm{~mm}$. long; sepals $4-5$, broadly rounded, $1.2 \mathrm{~mm}$. long; petals 4-5, suborbicular, about $1 \mathrm{~mm}$. long; stamens 8-12, the filaments about $0.5 \mathrm{~mm}$. long; pistillate flowers with 4 slightly imbricated sepals, the sepals about $1.2 \mathrm{~mm}$. long, disc somewhat fimbriated, fleshy; ovary globose, $0.7 \mathrm{~mm}$. long and $1 \mathrm{~mm}$. broad, style obsolete, stigmas 4 , spreading; ovules 8 , 2 on each of 4 parietal placentae; seeds about $1 \mathrm{~mm}$. long, pilose.

\section{GARPOTROCHE Endlicher}

Reference: H. Pittier, Contr. U. S. Nat. Herb. 12: 177-181, t. 19. 1909.

Shrubs or small trees, unarmed; leaves usually very large, short-petiolate, membranaceous or thicker, serrate or dentate or subentire; stipules lanceolate or subulate, caducous; flowers mostly large, white, chiefly in short, axillary and terminal cymes or racemiform cymes, sometimes arising on the branches below the leaves, polygamo-dioecious; sepals 3 ; petals $6-9$, strongly imbricate; stamens numerous, inserted on a small torus, the filaments short, the anthers linear; ovary with 6-7 placentae, the ovules numerous; styles 6-7, connate at the base, simple; fruit large, globose, baccate, bearing several or numerous broad vertical wings.

A small genus of tropical America with perhaps 8-10 species. There are two more species described (and one undescribed) from Costa Rica and Panama.

This genus has been considered by Macbride [Field Mus. Bot. 13 (4): 16. 1941] to be referable to Mayna. However, we believe it desirable, at least for the present, to maintain Carpotroche. A study of Carpotroche and allied genera of this difficult family is much needed.

Carpotroche platyptera Pittier, Contr. U. S. Nat. Herb. 12: 178, t. 19, f. 15, 16. 1909. Sucte; jaya.

Dense, wet, mixed, lowland forest, at or little above sea level; Izabal. Honduras to Panama, along the Atlantic coast.

A shrub or small tree, usually 2-5 meters high, with few branches, often simple; leaves on petioles $4-5 \mathrm{~cm}$. long, oblong-oblanceolate, mostly $30-50 \mathrm{~cm}$. long and 10-14 cm. wide, usually narrowly cuspidate-acuminate, long-attenuate to the base, coarsely dentate, finely and softly pubescent beneath or in age often almost glabrous, glabrate on the upper surface; staminate inflorescence much reduced and few-flowered, the flowers appearing almost sessile in the leaf axils or on the trunk, the pedicels and calyx densely pubescent; sepals 2-3, concave, furfuraceous outside; petals about $4.5 \mathrm{~mm}$. long, white, ovate or elliptic; stamens $15-19$, the 
anthers $2.5 \mathrm{~mm}$. long; pistillate flowers large, about $3 \mathrm{~cm}$. broad, the petals about 8 , elliptic-obovate, obtuse; ovary ovoid, pubescent; placentae generally 4 , the styles 4 , very short; fruit green or purplish, globose, about $5 \mathrm{~cm}$. in diameter, with several broad vertical wings.

The bark from plants of this genus is said to be rich in tannin. The wood is described as yellowish or pale brown, fine-textured, hard, tough, and strong, but apparently no use is made of it in Central America.

\section{CASEARIA Jacquin}

Trees or shrubs, commonly unarmed but sometimes with spinose branchlets; stipules mostly small and soon deciduous; leaves petiolate, entire or dentate, generally with pellucid dots or lines; flowers perfect, fasciculate or umbellate, sometimes solitary or racemose, greenish, whitish, or yellowish, small, the pedicels articulate, bracteate at the base; sepals $4-6$, imbricate; petals none; stamens usually $6-15$ (to 22 in $C$. spiralis), inserted in a single series on the tube of the calyx or at its base, alternating with staminodia; filaments free or united with the staminodia to form a ring; ovary free, ovoid or oblong, narrowed to a short style, the stigma capitate or with 3 stigmas; ovules numerous, on 3 parietal placentae; fruit capsular, fleshy or dry, 3-4-valvate, containing numerous seeds; seeds oblong or angulate, arillate; endosperm carnose, the embryo straight, the cotyledons oblong to rounded, flat, the radicle cylindric.

A genus found in the tropics of both hemispheres, chiefly in America and Africa. There are perhaps not more than thirty or forty species in the American tropics although many more have been described. A few others have been found in southern Central America and several more in Mexico.

Flowers in stipitate or pedunculate heads or in cymes or panicles.

Stamens $16-22 \ldots \ldots \ldots \ldots \ldots \ldots \ldots \ldots \ldots \ldots \ldots \ldots \ldots \ldots \ldots \ldots \ldots \ldots$ spiralis.

Stamens less than 12 .

Flowers in small, dense, stipitate or pedunculate heads......... arborea.

Flowers in cymes or panicles. . . . . . . . . . . . . . . . nitida.

Flowers in sessile fascicles borne in leaf axils.

Flowers small, about $2 \mathrm{~mm}$. long; leaves entire or obscurely denticulate.

Leaves rounded at the base, narrowly oblong, coloration of two sides con-

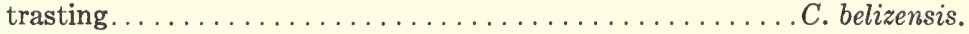

Leaves mostly acute at the base, lanceolate or lance-oblong, coloration of two sides similar. ........................ sylvestris.

Flowers larger, 3-12 mm. long; leaves entire or dentate.

Leaves serrate, with close, dense, and very acute, conspicuous teeth.

Leaves entire or sinuate dentate.

C. arguta.

Leaf blades mostly 4-8 cm. long, usually obtuse or narrowly rounded at the apex, obscurely crenate; plants usually spinose.......... aculeata.

Leaf blades mostly $10-18 \mathrm{~cm}$. long, acute or acuminate; plants unarmed. 
Sepals 8-12 mm. long.

Ovary and young fruit glabrous or sparsely pubescent; leaves glabrous.

C. Bartlettii.

Ovary and young fruit densely pilose or tomentose; leaves pilose be-

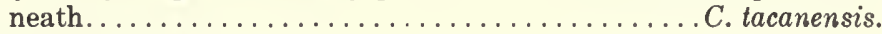

Sepals 2-6 mm. long.

Sepals $3 \mathrm{~mm}$. or less long; leaves mostly rounded at the base.

C. belizensis.

Sepals 3-4 mm. long; leaves mostly acute at the base, but sometimes obtuse................... javitensis var. myriantha.

Casearia aculeata Jacq. Enum. Pl. Carib. 21. 1760. C. hirta Swartz, Fl. Ind. Occ. 756. 1798. C. ramiflora Vahl var. spinosa Griseb. Fl. Brit. W. Ind. 24. 1859. Limoncillo; pullun (Petén, Maya).

Dry or moist thickets, sometimes in open forest, 350 meters or lower; Petén; Alta Verapaz; Izabal; Santa Rosa; Escuintla; Suchitepéquez; Retalhuleu; San Marcos; Huehuetenango. Southern Mexico; British Honduras to Honduras and Panama; West Indies; South America.

A shrub or tree, commonly 2-3 meters high but sometimes as much as 10 meters, with a trunk $10 \mathrm{~cm}$. or more in diameter, the branches of ten or occasionally armed with stout spines or branched thorns, puberulent to glabrate; leaves shortpetiolate, membranaceous or papyraceous, elliptic to obovate-elliptic, mostly 4 $8 \mathrm{~cm}$. long and very obtuse, broadly cuneate at the base, remotely serrate-dentate or almost entire, glabrous or nearly so, the lateral nerves 4-5 pairs; flowers fasciculate in the leaf axils, the pedicels short, articulate at the middle or lower, $5-7 \mathrm{~mm}$. long; sepals $4-5 \mathbf{~ m m}$. long, greenish white; stamens glabrous, the staminodia villous; ovary villous; fruit subglobose, obtusely trigonous, 6-12 mm. long.

Called "escambrón" and "aguja de árrea" (Honduras); "wild lime," "bird berries," "limoncillo" and "ramoncillo" (British Honduras); "cedrón" (Oaxaca). A common shrub in dry thickets or second growth of the Pacific plains, often forming dense tangles of spiny branches.

Casearia arborea (L. Rich.) Urban, Symb. Antill. 4: 421. 1910. Samyda arborea L. Rich. Act. Soc. Hist. Nat. Paris 1: 109. 1792.

Wet forest or thickets, at or near sea level; Izabal. British Honduras; Nicaragua; Costa Rica; Panama(?). Greater Antilles; Guianas and Brazil.

A large shrub or tree, sometimes 9 meters high with a trunk $10 \mathrm{~cm}$. in diameter, the branches slender, when young puberulent or glabrate; leaves on very short petioles, narrowly oblong or oblong-lanceolate, mostly 5-12 cm. long, narrowly long-acuminate, acute or very obtuse at the base and often somewhat unequal, distichous, closely serrulate-dentate, glabrous and lustrous above, paler 
beneath, sometimes pale-tomentulose; flowers subcapitate, white, the heads shortpedunculate or stipitate, the peduncles or stipes mostly $2-3 \mathrm{~mm}$. long, the pedicels about equaling the calyx, puberulent; sepals $3.5-4.5 \mathrm{~mm}$. long; staminodia pilose; stamens 10; ovary glabrous except at the apex; fruit ellipsoid, $4 \mathrm{~mm}$. long.

Casearia arguta HBK. Nov. Gen. \& Sp. 5: 364. 1821. Manzanilla; raspa-lengua; ixim-ché (Alta Verapaz); guayabillo; camché (fide Aguilar).

Dry or moist thickets or open forest, often in second growth, 2,000 meters or less, most common at low elevations; Alta Verapaz; Izabal; Jutiapa; Santa Rosa; Escuintla; Guatemala; Quiché; Suchitepéquez; Retalhuleu; Quezaltenango; San Marcos. Western and southern Mexico; British Honduras and El Salvador to Panama. South America.

A shrub or small tree, unarmed, usually 2-5 meters tall but sometimes a tree of 12 meters with a trunk $30 \mathrm{~cm}$. in diameter, the branches grayish or pale brown, the trunk often crooked, the crown spreading, the branches usually pubescent; leaves short-petiolate, membranaceous, oblong, lance-oblong, or oblong-elliptic, $7-15 \mathrm{~cm}$. long, acuminate or narrowly long-acuminate, rounded to acute at the base, closely and acutely serrate throughout, glabrous above or nearly so, glabrate beneath or densely pilose, even in age, sparsely punctate, usually barbate in the leaf axils; flowers greenish white or creamy yellow, densely fasciculate, the pedicels 2-4 mm. long, densely pubescent; sepals $4-5 \mathrm{~mm}$. long, densely pubescent; stamens generally 8 , the staminodia white-villous; stigma entire; fruit subglobose, 1-2 cm. in diameter at maturity; aril of the seeds red.

The flowers have a honey-like odor. The inflorescences sometimes are fasciated and deformed, presumably as the result of insect attacks. Called "cuculmico" in El Salvador; in British Honduras "hard moho" and "monkey plum." The wood is creamy white or pale yellow, the scant heartwood dark red or almost black. The ripe fruit is yellow. This species is especially common on the Pacific plains and foothills of Guatemala.

Casearia Bartlettii Lundell, Lloydia 2: 104. 1939 (type from Guatemala, Bartlett 12558); C. elegans Standl. in Yuncker, Field Mus. Bot. 9: 311. 1940 (type from Honduras, Yuncker et al. 8804); Samyda Bartlettii Lundell, Wrightia 2: 56. 1960.

Wet, mixed forest at or near sea level; Petén; Izabal. Mexico (Michoacán, Tabasco); Honduras.

A slender shrub or small tree, sometimes 7 meters high, the branchlets pilosulous or puberulent at first, soon glabrate; petioles mostly 4-10 mm. long; leaf blades membranaceous, oblong-oblanceolate to obovate-oblong, 10-19 $\mathrm{cm}$. long, $3-6.5 \mathrm{~cm}$. wide, gradually or abruptly acuminate or long-acuminate, acute at the base or usually gradually long-attenuate, glabrous, serrate or serrulate or sub- 
entire, sparsely pellucid-lineolate, green when dried, the lateral nerves about 8 pairs; flowers axillary, solitary or in few-flowered fascicles, the very slender pedicels 5-7 mm. long or even longer, densely short-pilosulous; sepals white, obovateoblong, 7-12 mm. long, obtuse or rounded at the apex, densely and minutely puberulent outside; stamens 6-12, the filaments glabrous; staminodia densely pilose; ovary glabrous; fruit ovoid, about $2.5 \mathrm{~cm}$. long and $1.5 \mathrm{~cm}$. broad, apiculate, acutish at the base, prominently ridged.

\section{Casearia belizensis Standl. Field Mus. Bot. 12: 412. 1936.}

Wet forest, near sea level; Izabal. British Honduras (type, Schipp 1314). Nicaragua; Costa Rica.

A tree, sometimes 12 meters high, the trunk $25 \mathrm{~cm}$. in diameter, the young branchlets minutely puberulent, soon glabrate; leaves thick-chartaceous, on petioles 5-8 $\mathrm{mm}$. long, narrowly oblong, 6-21 cm. long, $2.5-5 \mathrm{~cm}$. wide, cuspidateacuminate with a long narrow tip, obliquely rounded at the base or subcordate, inconspicuously and closely appressed-crenate, very densely pellucid-punctate, glabrous, lustrous above, paler and brownish beneath, the lateral nerves about 10 pairs; flowers pink, numerous, fasciculate in the leaf axils or at defoliated nodes, the slender pedicels glabrous, $1 \mathrm{~cm}$. long or less; sepals oval, glabrous, $2 \mathrm{~mm}$. long or slightly larger; stamens 8 , glabrous; ovary glabrous; the style short and thick, entire.

In British Honduras the tree is called "drunken bayman wood"; in Costa Rica it is called "espino amarillo," and a tree there has been reported to be 110 feet tall and 32 inches D.B.H. and to be used as ordinary lumber.

Casearia javitensis HBK. var. myriantha (Turcz.) L. Wms Fieldiana, Bot. 29: 359. 1961. C. myriantha Turcz. Bull. Soc. Nat' Mosc. 36: 609. 1863. C. Brighamii Watson, Proc. Amer. Acad. 21: 459. 1886 (type Izabal, S. Watson 18). C. laetioides Warb. in Engl. \& Prantl, Pflanzenfam. 3, Abt. 6a: 52. 1893 (type from Izabal, Bernoulli 896). Mierda de gallina (Petén); taixcaax, utaxcaax (Petén, Maya, fide Lundell); cakica-che (Alta Verapaz); guayabillo.

Moist or wet thickets or forest, or often in dry situations, 1,200 meters or less; Petén; Alta Verapaz; Izabal; Escuintla; Retalhuleu; Quezaltenango. Southern Mexico; British Honduras to Panama; northern South America.

A shrub or tree, sometimes 11 meters high with a trunk $20 \mathrm{~cm}$. in diameter, the bark smooth, pale, the rather stout branches glabrous or puberulent; leaves on short thick petioles, coriaceous, oblong to elliptic-oblong or lance-oblong, 8$25 \mathrm{~cm}$. long, acuminate or long-acuminate, usually acute at the base, very lustrous, opaque, glabrous, rather inconspicuously appressed-serrate, the lateral nerves about 8 pairs; flowers white or greenish white, densely fasciculate, the pedicels often very numerous, $7 \mathrm{~mm}$. long or less, densely puberulent; sepals $3-4 \mathrm{~mm}$. 
long, appressed-pilosulous with pale hairs; stamens 10-15, slightly longer than the sepals; stigma 3-fid; capsule sparsely pilose, about $1 \mathrm{~cm}$. long, thin-walled, turning red and finally brown.

Called "cafecillo" and "pochitoquillo" in Tabasco. This is distinguished from all other local species by its coriaceous, lustrous leaves and pubescent calyces. Casearia belizensis is possibly only a somewhat pubescent phase of this species and perhaps should be considered another variety of it.

Casearia nitida Jacq. Enum. Pl. Carib. 21. 1760. Samyda nitida L. Syst. Nat. ed. 10, 1025. 1759. C. corymbosa HBK. Nov. Gen. \& Sp. 5: 366. 1821. C. banquitana Krause, Beih. Bot. Centralbl. 32, Abt. 2: 345. 1914. C. laevis Standl. Contr. U. S. Nat. Herb. 23: 845. 1923. C. mollifolia Standl. Field Mus. Bot. 9: 311. 1940. C. Gentlei Lundell, Field \& Lab. 13: 9. 1945 (type from British Honduras, Gentle 4489). C. banquitana var. laevis Johnston, Sargentia 8: 211. 1949. Cf. L. Wms. Fieldiana, Bot. 29: 359. 1961. Vara blanca; sakiche, ixim-te (Alta Verapaz); café de monte; café de montaña; balelac de aguada; canjuro; iximche (British Honduras, Maya).

Dry, wet or moist forests or thickets, often in second growth, abundant in many regions, especially along the Pacific plains and foothills, 1,300 meters or lower; Petén; Alta Verapaz; El Progreso; Izabal; Zacapa; Jutiapa; Santa Rosa; Escuintla; Guatemala; Sacatepéquez; Huehuetenango; Quezaltenango; San Marcos. Mexico to Panama; the West Indies; northern South America.

A shrub or small tree, sometimes to $9 \mathrm{~m}$. tall but usually less, the bark and branches whitish, the branchlets pilose or glabrous; leaves short-petiolate, membranaceous, elliptic or oblong-elliptic, lance-oblong or oblong, mostly $4-9 \mathrm{~cm}$. long and $3-5 \mathrm{~cm}$. broad, acute or acuminate, rarely obtuse, rounded to acute at the base, pellucid-punctate, serrulate to subentire, from entirely glabrous to densely velutinous-pilose below, sometimes pilose above; flowers in short corymbs or panicles, few- to several-flowered, the pedicels short or rather elongate, pilosulous to pilose; sepals 3-4 $\mathrm{mm}$. long, usually densely puberulent to pilosulous; stamens usually 8; stigma entire; fruit ovoid or ellipsoid, $8 \mathrm{~mm}$. long or more, becoming red or yellow.

Known in El Salvador as "canjuro," "chilillo," and "come-culebra," "comida de culebra" in Honduras; "paletillo" in British Honduras; "cafetillo" in Tabasco; "xmaben-che" in Yucatecan Maya. The name "iximche," Maya and signifying "maize-tree," is of interest. There is no obvious reason why the tree should be so called, but the name and the tree probably have some connection with the old Indian capital of Iximche, near Tecpán in the department of Chimaltenango. 
The description above covers both the glabrous and the pubescent phases of this species. The pubescent form, which has received several names, varies from puberulent to densely pilose-pubescent and seems to occur within the range of the typical glabrous form from Mexico at least to Nicaragua.

The name Casearia nitida Jacq. should not be written with a parenthetical authority.

Casearia spiralis J. R. Johnston, Proc. Am. Acad. 40: 691. 1905. Zuelania belizensis Lundell, Wrightia 1: 58. 1945 (type from British Honduras, Gentle 4649).

Secondary forests, often in swampy places. British Honduras; Mexico; Venezuela.

Trees to $15 \mathrm{~m}$. tall, the branches dark with a few white, round to elongate lenticels, glabrous; leaves lanceolate-ovate to oval, acute or acuminate, membranaceous, somewhat pellucid, obscurely denticulate or entire, glabrous, lateral nerves mostly 8-12 pairs, the blade 4-9 $\mathrm{cm}$. long and 1.5-4 (5) $\mathrm{cm}$. broad, the petiole short, slender, $0.5-1.2 \mathrm{~cm}$. long; inflorescence a pedunculate or stipitate fascicle or perhaps condensed, paniculate, many-flowered, and borne on short pseudobranches; sepals tepal-like, 6 in an outer and an inner series, imbricate, those of the outer series smaller, lanceolate and about 4-5 mm. long, those of the inner series larger, oval and 5-6 $\mathrm{mm}$. long; petals none; stamens 16-22 with shorter alternating staminodia, the filaments pilose to nearly glabrous, the staminodia densely pilose-pubescent; ovary ovoid, pubescent at least when young.

Unlike other species of Casearia in the larger number of stamens, and in the showy tepal-like sepals which were originally described as cyclic or spiralled.

The disjunct range is of interest. We have not been able to find this species among West Indian material, although it should occur there.

Casearia sylvestris Swartz, Fl. Ind. Occ. 2: 752. 1800. Samyda parviflora L. Syst. Nat. ed. 10. 1025. 1759, not Loefl. 1758. C. parviflora Willd. Sp. Pl. 2: 627. 1799. Coralillo (Suchitepéquez); sacumba (Alta Verapaz).

Moist or dry forest or thickets, often in second growth, 1,200 meters or less, chiefly at low elevations; Petén; Alta Verapaz; Izabal; Santa Rosa; Escuintla; Retalhuleu; Suchitepéquez; Sololá; Huehuetenango. Mexico; British Honduras to Panama; West Indies; South America.

A shrub or tree, sometimes 9 meters high with a trunk $15 \mathrm{~cm}$. in diameter but usually lower, the branches mostly long and slender, whitish or pale brownish; 
leaves on very short petioles, membranaceous or chartaceous, lanceolate or lanceoblong, mostly $6-10 \mathrm{~cm}$. long and $2-3 \mathrm{~cm}$. wide, narrowly long-acuminate, acute and oblique at the base, entire, glabrous or nearly so, densely pellucid-punctate; flowers small, white or greenish white, numerous, densely fasciculate in the leaf axils, the pedicels $2-4 \mathrm{~mm}$. long, glabrous or pubescent, often almost obsolete; sepals 1.5-2 mm. long, glabrous or puberulent; stamens 10; stigma 3-lobate; fruit subglobose, red, 3-4 $\mathrm{mm}$. in diameter, 2-6-seeded.

Called "wild sage" in British Honduras; "sombra de armado," "sombra de conejo" (Honduras). The wood is said to be yellow, hard, heavy, and compact, and to be used in some regions for construction purposes when available in large enough pieces.

The typical phase of this species is glabrous. A phase with pubescent pedicels and calyces is found through most of Central America.

\section{Casearia tacanensis Lundell, Lloydia 4: 54. 1941.}

At 1,000-2,000 meters; Chiapas; type from Volcán de Tacaná, E. Matuda 2441; doubtless extending into San Marcos.

A tree of 6-10 meters, the trunk as much as $15 \mathrm{~cm}$. in diameter, the branchlets brownish-tomentose; leaves firm-membranaceous, on stout petioles $3-6 \mathrm{~mm}$. long, lance-oblong or elliptic-oblong, $8.5-18 \mathrm{~cm}$. long, 3-5 cm. broad, acuminate, acute at the base, almost glabrous on the upper surface, brown-pilose beneath, obscurely crenulate-serrate; flowers fasciculate, numerous, the pedicels $5-8 \mathrm{~mm}$. long, articulate near the middle, brown-tomentulose; calyx tomentulose, $8 \mathrm{~mm}$. long or somewhat shorter, the 5 lobes linear-lanceolate, attenuate, reflexed at about the middle; stamens 10 , the filaments sparsely pilose, joined into a tube and connate to the sepals; staminodia densely pilose; ovary densely brown-pilose; fruit globose, $2 \mathrm{~cm}$. or slightly more in diameter, densely, coarsely, and irregularly obtusetuberculate, densely brown-tomentose.

This is perhaps the most unusual species of the genus. The large tuberculate fruits are not duplicated in any other species.

Flacourtia Ramontchi L'Hèr., the Governor plum or Batoko plum, native of the Zambesi region of Africa, is planted in a few localities in Guatemala, as at Finca El Zapote, Escuintla. It is a shrub or small tree, with or without spines, the leaves oblong to elliptic or obovate, obtuse or acute, crenate-dentate, short-petiolate; sterile flowers in short racemes, the fertile ones solitary or geminate; fruit cherry-like, $2.5 \mathrm{~cm}$. or less in diameter, purple, red, or blackish, containing 8-10 seeds. The fruit is edible, and on this account the plant has been introduced into cultivation in the West Indies and elsewhere in America, but apparently never has become popular. 


\section{HASSELTIA HBK.}

Shrubs or trees; leaves slender-petiolate, 3-nerved from the base, alternate, entire or serrate, usually with glands on the upper side at the base of the blade; stipules small, caducous; flowers small, white, cymose or corymbose, terminal, pedicellate, perfect; sepals 4-5, valvate, persistent; petals 4-5, persistent, resembling the sepals and alternate with them; stamens numerous, free, inserted upon small eglandular disk, the filaments filiform, the anthers small, subglobose, 2celled, longitudinally dehiscent; ovary free, 2-celled, the ovules numerous, the style subulate, entire; seeds usually 1 in each cell, sometimes 2, pendulous, the testa coriaceous, the endosperm carnose; embryo straight, the cotyledons flat, foliaceous.

About five species, ranging from Mexico to Peru in continental America. One other species, H. floribunda HBK., occurs in Central America from Honduras to Panama, and in South America.

Hasseltia guatemalensis Warb. in Engl. \& Prantl, Pflanzenfam. 3, Abt. 6a: 32.1893 (type from Santa María; probably Santa María de Jesús, Quezaltenango, Bernoulli \& Cario 2920). Canela de montaña.

Moist or wet, mixed forest, also in coffee plantations, 1,200-1,500 meters; Suchitepéquez; Quezaltenango; San Marcos. Mexico (Chiapas); Nicaragua.

A tree of 9-20 meters, the trunk $30 \mathrm{~cm}$. or less in diameter, the bark close, gray, slightly rough, glabrous throughout or nearly so; petioles $1-3.5 \mathrm{~cm}$. long; leaf blades oblong-elliptic to elliptic or oblong-obovate, $18 \mathrm{~cm}$. long and $8 \mathrm{~cm}$. wide or smaller, very obtuse to short-acuminate, broadly acute to narrowly cuneateacute at the base, with 2 small glands on the upper side at the base, subentire, 3-plinerved, the costa emitting 3-4 pairs of lateral nerves above the basal nerves; inflorescence usually large and many-flowered, broadly corymbose and repeatedly dichotomous, the flowers aggregate in umbels, the pedicels mostly $1-1.5 \mathrm{~cm}$. long, glabrous, the flowers white; sepals $3-4 \mathrm{~mm}$. long, the outer ones almost glabrous outside, the petals tomentulose; fruit glabrous, subglobose, $1 \mathrm{~cm}$. in diameter.

\section{HOMALIUM Jacquin}

References: S. F. Blake, The genus Homalium in America, Contr. U. S. Nat. Herb. 20: 221-235. 1919; L. Wms. Fieldiana, Bot. 29: 362. 1961.

Shrubs or large trees; leaves alternate, petiolate, glandular-crenate or serrate, rarely entire; stipules small; flowers small, in axillary panicles; calyx tube turbinate, connate with the base of the ovary, the lobes $6-7$, persistent; petals $6-7$, inserted in the throat of the calyx, narrow, persistent, plane; stamens collected in fascicles opposite the petals and alternating with glands, the filaments filiform, the anthers small, didymous; ovary semisuperior, the styles $2-5$, filiform, the stigmas simple or capitellate; ovules few or numerous, affixed to $2-5$ parietal placentae; capsule 
semisuperior, coriaceous, 2-5-valvate at the apex, few-seeded; seeds angulate or oblong, with crustaceous testa, the endosperm carnose; cotyledons foliaceous.

Species 40 or more, in the tropics of both hemispheres. No other species are known from Central America.

Stamens 5 or more in each fascicle; the filaments pilose, at least toward the base.

$H$. trichostemon.

Stamens 4 or fewer (usually 3 ) in each fascicle; filaments not pilose. .H. racemosum.

Homalium racemosum Jacq. Enum. Pl. Carib. 24. 1760. H. hondurense Donn.-Sm. Bot. Gaz. 20: 4. 1895. H. nicaraguense Blake, Contr. U. S. Nat. Herb. 20: 225. 1918. H. riparium Standl. Carnegie Inst. Wash. Publ. 461: 74. 1935, not Gilg, 1908 (type, British Honduras, Schipp 1182). H. Schippii Standl. Tropical Woods 52: 27. 1937.

Moist to wet forest, at or little above sea level; Petén, possibly also Alta Verapaz. British Honduras; Mexico through Central America; the West Indies; northern South America to Brazil and Colombia, perhaps Peru.

A tree to $15 \mathrm{~m}$. high with a trunk $20 \mathrm{~cm}$. or more in diameter, the branchlets glabrous; leaves on petioles $5-8 \mathrm{~mm}$. long, oblong-lanceolate or oblong, mostly 7-12 cm. long and $2.5-4.5 \mathrm{~cm}$. wide, narrowly long-acuminate to acute, acute or obtuse at the base, crenate-serrate, glabrous, lustrous, the lateral nerves about 8 pairs; flowers whitish, the racemes usually many-flowered, $16 \mathrm{~cm}$. long or less, the rachis densely puberulent, the pedicels $1-8 \mathrm{~mm}$. long, the bracts subulate, of ten persistent and conspicuous; calyx tube obconic, acute at the base, the sepals lanceoblong, 2.5-5 mm. long, obtuse, tomentulose, $1.2-2 \mathrm{~mm}$. wide; petals white, $3-$ $7 \mathrm{~mm}$. long, oblong-elliptic, acute or subobtuse, densely tomentulose; stamens 3-4 in each fascicle, the filaments glabrous; ovary densely hirsute.

The flowers are said to have an unpleasant odor.

Homalium trichostemon Blake, Contr. Gray Herb. 53: 60. 1918.

Common along rocky river banks, about 300 meters; Escuintla. Southern Mexico.

A tree 9-12 meters high or larger, the trunk of ten $30 \mathrm{~cm}$. or more in diameter, the bark thin, light gray, the crown broad or narrow; petioles 4-7 $\mathrm{mm}$. long; leaf blades elliptic-oblong to elliptic or oval, 6-13 cm. long, 3-6 cm. wide, acuminate to obtuse, cuneate to rounded at the base, crenate-serrate, barbellate beneath in the nerve axils, otherwise glabrous, the lateral nerves 7-8 pairs; racemes simple, solitary or geminate, lax or dense, the rachis puberulent or pilosulous, the pedicels mostly 1-3 mm. long; calyx tube in fruit densely puberulent, the sepals $6-7$, ovatelanceolate, subobtuse, 4-4.5 mm. long, $1.5-1.8 \mathrm{~mm}$. wide; petals ovate, obtuse, puberulent and ciliate, $4.8-5.5 \mathrm{~mm}$. long; stamens in fascicles of $5-7$, the filaments pilose to the middle, shorter than the petals. 
Called "palo de piedra" in Oaxaca. The wood is described as light brown throughout. The tree is a characteristic one along rocky banks of streams on the plains between Escuintla and the coast.

\section{LAETIA Loefling}

Shrubs or trees; leaves petiolate, crenate, serrate, or subentire, pellucid-punctate; flowers perfect, axillary or terminal, fasciculate or corymbose; sepals $4 \mathbf{- 5}$, broad, somewhat petaloid, imbricate, reflexed in anthesis; petals none; stamens usually numerous, inserted on an eglandular disk, the anthers ovoid; ovary 1celled, with 3 placentae, many-ovulate; style simple, the stigma capitate or obsoletely lobate; fruit baccate, sometimes resinous within, tardily dehiscent by valves; seeds arillate, with coriaceous testa; embryo straight, the cotyledons broad.

Ten or more species, in tropical America. A single species is known from continental North America.

Laetia Thamnia L. Amoen. Acad. 5: 413, 379. 1760. L. americana L. Syst. ed. 10. 1074. 1759, in part. Hueso de tortuga (Petén); ixbakelac, bakelac (Petén, Maya).

Moist or wet forest or thickets, at or little above sea level; Petén; Izabal. Campeche to Chiapas, Yucatan, and Tabasco in Mexico; British Honduras; Honduras; Panama; West Indies; Colombia.

A shrub or tree, sometimes 10 meters high with a trunk $10-40 \mathrm{~cm}$. in diameter, the young branches glabrous; stipules minute, deltoid-ovate, deciduous; leaves short-petiolate, membranaceous, elliptic to oblong-lanceolate or oblanceolateoblong, mostly $6-15 \mathrm{~cm}$. long, acute or acuminate, obtuse or narrowly rounded at the base, entire or obscurely crenulate, pellucid-punctate; flowers fragrant, white or cream sometimes tinged with pink, in few-flowered pedunculate corymbs much shorter than the leaves, slender-pedicellate; sepals 4, mostly 4-6 mm. long, sparsely puberulent; filaments pubescent; fruit globose, fleshy, $1.5-4 \mathrm{~cm}$. in diameter, 4-5-valvate, many-seeded, densely and closely tomentulose.

\section{LINDACKERIA Presl}

Shrubs or trees; leaves alternate, long-petiolate, penninerved; flowers rather small, polygamous, in small or large, axillary, usually many-flowered panicles or racemes; sepals 3 , imbricate; petals 6-12, imbricate; stamens numerous, free or united, the filaments filiform, the anthers linear; ovary stipitate, 1-celled, muricate, with 3 parietal placentae, the ovules numerous; style elongate, simple, the stigma 3-lobate; fruit globose, coriaceous or subligneous, densely tuberculate or echinate, finally 3-2-valvate, few-seeded; seeds ovoid, with crustaceous testa, the cotyledons ovate, foliaceous, inflexed at the apex; endosperm copious.

About 12 species, in tropical America and Africa. A single species is found in North America. The genus is closely related to Mayna and not very distinct from it. 
Lindackeria laurina Presl, Rel. Haenk. 2: 89, t. 65. 1836. Oncoba laurina Warb. in Engl. \& Prantl, Pflanzenfam. 3, Abt. 6a: 19. 1894. Mayna laurina Benth. Journ. Linn. Soc. Bot. 5: Suppl. 81. 1861.

Wet forest, at or little above sea level; Izabal. British Honduras; along the Atlantic coast to Panama.

A large shrub or a tree, sometimes 15 meters high with a trunk $25 \mathrm{~cm}$. in diameter, the crown spreading or pyramidal, the bark gray, very viscid on the younger parts and on the leaves, glabrous almost throughout; leaves on long slender petioles, membranaceous or thicker, lance-oblong or ovate-oblong, $12-30 \mathrm{~cm}$. long, cuspidate-acuminate, obtuse at the base, entire, very lustrous, brownish beneath when dried; panicles long and narrow, pedunculate, usually shorter than the leaves, sparsely puberulent, the flowers pedicellate; sepals and petals white, the petals $1 \mathrm{~cm}$. long or less; stamens yellow; fruit globose, green, $1 \mathrm{~cm}$. in diameter, covered with long slender flexible spines; seeds 1-4.

In the fresh state the foliage is very viscid and adheres to the fingers and to clothing. The name "achiote" has been reported for this tree in Guatemala, but probably in error.

The species is reported from Colombia and Venezuela but specimens we have seen, so determined, perhaps belong elsewhere.

\section{LUNANIA Hooker}

Trees or shrubs with slender branches; leaves alternate, petiolate, entire, 3-5-nerved, minutely pellucid-punctate; stipules none; flowers small, in slender, axillary or terminal, simple or branched, often nutant racemes, the pedicels articulate at the base, minutely several-bracteate; calyx subglobose, finally valvately cleft into 2-3 spreading membranaceous sepals; petals none; stamens 6-10, inserted about a cupular disk; filaments short, the anthers ovoid or oblong, extrorsely dehiscent; ovary ovoid, 1-celled, attentuate to a short or elongate, 3-lobate style, the stigmas truncate; placentae 3 , parietal, the ovules numerous, multiseriate; fruit capsular, coriaceous, globose, 3 -valvate, few-seeded; seeds small, globose, usually deeply punctate, arillate, with endosperm.

About 15 species, ranging from southern Mexico to northern South America. Two other Central American species are known, in Honduras and Costa Rica.

Lunania mexicana T. S. Brandegee, Univ. Calif. Publ. Bot. 6: 56. 1914. Palo chito; chile de montaña.

Dense, moist or wet, mixed, mountain forest, 750-2,000 meters; Chimaltenango; Suchitepéquez; Sololá; Quiché; Quezaltenango; San Marcos. Mexico (Chiapas); Honduras.

A large slender shrub or a tree, sometimes 11 meters high, the young branches densely and minutely puberulent; leaves short-petiolate, lance-oblong, mostly 7- 
$12 \mathrm{~cm}$. long, cuspidate-acuminate with a long narrow tip, crenulate to almost entire, membranaceous, obtuse or rounded at the base and somewhat asymmetric, 3-nerved from the base, the upper lateral nerves 3-4 pairs, minutely puberulent beneath on the nerves, barbate in the nerve axils; racemes simple or branched, 5-10 cm. long, puberulent; flowers short-pedicellate, green, $2 \mathrm{~mm}$. long, the sepals reflexed; stamens $7-9$; ovary puberulent.

A second and undescribed species of Lunania is represented by a sterile specimen from Huehuetenango: Steyermark 51160, from Paso del Boquerón, along Río Trapichillo, below La Libertad, 1,200-1,300 meters. In this the leaf blades are rounded and subcordate at the base, and the petioles are densely hirtellous (glabrous in L. mexicana). There can be no doubt as to the reference of the specimen to this genus, but since it is sterile it probably should not be given a name.

\section{OLMEDIELLA Baillon}

Dioecious trees; leaves persistent, coriaceous, usually with coarse spine-tipped teeth, bearing 2 large glands on the upper side at the base of the blade, penninerved; flowers small, unisexual; sepals of staminate flowers 14-15, acute, imbricate; petals none; stamens very numerous, the filaments slender, the anthers small, ovate, longitudinally dehiscent; sepals of pistillate flowers 7-9; petals none; nectaries forming 1-3 rows about the ovary, with staminodia between them; ovary superior, with 6-8 imperfect cells; style short, the stigmas $6-8$, sulcate above; fruit baccate, depressed-globose.

The genus consists of a single species.

Olmediella Betschleriana (Goepp.) Loes. Notizbl. Bot. Gart. Berlin 4: 181. 1906. Ilex Betschleriana Goepp. Del. Sem. Vratisb. 1852; Linnaea 26: 745. 1853-54. O. ilicifolia Baill. Bull. Soc. Linn. Par. 1: 253. 1880. O. Cesatiana Baill. loc. cit. Licopolia sincephala Rippa, Bull. Orto Bot. Napoli 2: 74. 1904. Croton Tuerckheimii Donn.-Sm. Bot. Gaz. 54:242. 1912 (type from Tactic, Alta Verapaz, Tuerckheim II. 2163). Manzanote; manzana; semito; roble de montaña.

Dense, wet or moist, mountain forest, 1,500-2,700 meters; Alta Verapaz; Zacapa; Chiquimula; El Progreso; Jalapa; Guatemala; Sacatepéquez; Chimaltenango; Sololá; Suchitepéquez; Quezaltenango; San Marcos; Huehuetenango. Mexico (Chiapas); El Salvador; Honduras.

A glabrous tree, often 15 meters high or more, with a dense or open crown, the trunk low or tall, of ten $35 \mathrm{~cm}$. or more in diameter; leaves coriaceous, on short or rather long petioles, mostly oblong or elliptic-oblong and $8-15 \mathrm{~cm}$. long, acute to long-acuminate and spine-tipped, rounded or obtuse at the base, lustrous, slightly paler beneath, the lateral nerves 6-9 pairs, the margin cartilaginous-thickened, coarsely sinuate-dentate, with stiff spine-tipped teeth, or leaves on flowering 
branches often quite entire; inflorescences few-flowered and inconspicuous, the flowers green, the staminate in short racemes, the pedicels 7-14 $\mathrm{mm}$. long; sepals cuspidate-ovate, $1.5-2 \mathrm{~mm}$. long, the receptacle $4-6 \mathrm{~mm}$. broad; stamens about 60-85, the anthers $1 \mathrm{~mm}$. long; fruit depressed-globose, somewhat resembling a small apple, green, almost smooth, 5-6 cm. broad, flattened at the apex.

Called "cumbo de cerro" and "cajón de burro" in Honduras. In some respects this is one of the most interesting trees of Guatemala, where it is known generally by the name "manzanote." It has had a varied taxonomic history, as the synonymy cited above well indicates. It has been in cultivation in Europe, particularly Italy, for more than 90 years, seeds probably having been sent there from Guatemala City by some Italian who admired the handsome hollylike foliage of the tree. In Europe, apparently, the tree seldom flowers or fruits, and botanists who saw the plants had great difficulty in guessing their proper relationship. The leaves are so much like those of holly that it is not surprising that the species was first described under the genus Ilex. The genus was guessed also as Sapium and Quercus, and it was placed by Baillon in the Moraceae. The early history of the tree has been brought together by Loesener (loc. cit.), who gave a most satisfactory account also of the true relationship of the genus, which is with the African genus Doryalis. The source of the European plants remained unknown until 1932, when the senior author was able to report definitely (Trop. Woods 32: 17) that Olmediella was a native of the Guatemalan mountains, on the basis of material furnished by don Jorge García Salas, then of the Dirección General de Agricultura. Manzanote trees grow abundantly in many of the Guatemalan mountains at middle or rather high elevations, and they are particularly plentiful on the slopes of the volcanoes of Pacaya and Acatenango, as well as elsewhere in the central region. As seen in the forest, there is little to call attention to the tree, except that its spiny leaves are unusual. In the forest the tree is often exceedingly tall, of irregular branching, the crown high overhead. However, someone must have had some reason for introducing it into cultivation long ago, and it has now become one of the favorite park and street trees of the central region. Under cultivation it has a low trunk and a very dense, rounded crown of handsome, deep green leaves. It stands pruning well, and many of the street and park trees are trimmed closely, to produce dense globular crowns that have a formal and somewhat artificial appearance, but are nevertheless very handsome. Almost every child of Guatemala City sees manzanote trees in the course of the day, for they are planted in the parks and along the streets, the finest being along the 
Paseo de la Reforma, the principal boulevard. There are fine individuals also in the Parque Central of Antigua, in front of the ancient Palace of the Viceroys of Guatemala. The tree well deserves extensive cultivation in other regions that are cool and moist but not too cold. Probably it would succeed in some parts of California and in various parts of southern Europe, as well as in cooler regions of the West Indies and South America. The leaves are exceedingly variable in their margins, the great majority of them being coarsely spine-toothed so as to resemble closely the common American or European hollies, but on fertile branches they often are quite entire and so distinct in appearance that one with only a herbarium acquaintance with specimens would feel sure two distinct species were represented.

\section{PLEURANTHODENDRON L. Wms.}

Small trees. Leaves alternate, petiolate, biglandular at the junction of the blade and the petiole or glands obscure; tri-quinqueplinerved at the base, the margin entire to serrate, the teeth sometimes gland-tipped. Inflorescence often a diffuse panicle or panicles, originating in the axils of the upper leaves or terminal; the bracteoles early deciduous and the scar often glandular. Flowers perfect; sepals 4-6, valvate; petals 4-6, alternate with the sepals, soon falling; stamens numerous; anthers small, bilocular, the cells opening longitudinally. Ovary superior, sessile, tomentose, 1-celled, placentae 3-4. Fruit a subcoriaceous capsule.

The following is the only species of the genus.

Pleuranthodendron mexicana (Gray) L. Wms. Fieldiana, Bot. 29: 365. 1961. Banara mexicana Gray, Proc. Am. Acad. 5: 174. 1862 (type from Mexico). Hasseltia pyramidalis Hemsl. Diag. Pl. Mex. 4. 1878 (type from Mexico). Hasseltia mexicana Standl. Contr. U. S. Nat. Herb. 23: 840. 1923. Chichimí quina (Izabal); madrón (Guatemala).

Wet to dry forests, most common at lower elevations, rarely to 1,500 m.; Petén; Alta Verapaz; Izabal; Escuintla; Guatemala; Chimaltenango; San Marcos. Mexico (San Luis Potosí and Veracruz), through Central America to Colombia, Peru and Brazil. Figure 12.

A large shrub or usually a tree, sometimes 15 meters high with a trunk $35 \mathrm{~cm}$. in diameter, the crown usually spreading, the branchlets minutely puberulent at first, soon glabrate; leaves on slender, short or elongate petioles, oblong-lanceolate to oblong-elliptic or elliptic, mostly $7-15 \mathrm{~cm}$. long, abruptly short-acuminate, obtuse or acute at the base, with 2 large glands on the upper side of the blade at its base, glabrous or nearly so, crenate-serrate, 3-nerved from the base; flowers white or cream, in small or large panicles, the branches of the panicle densely and minutely puberulent; sepals densely tomentulose, $4 \mathrm{~mm}$. long; fruit subglobose, 


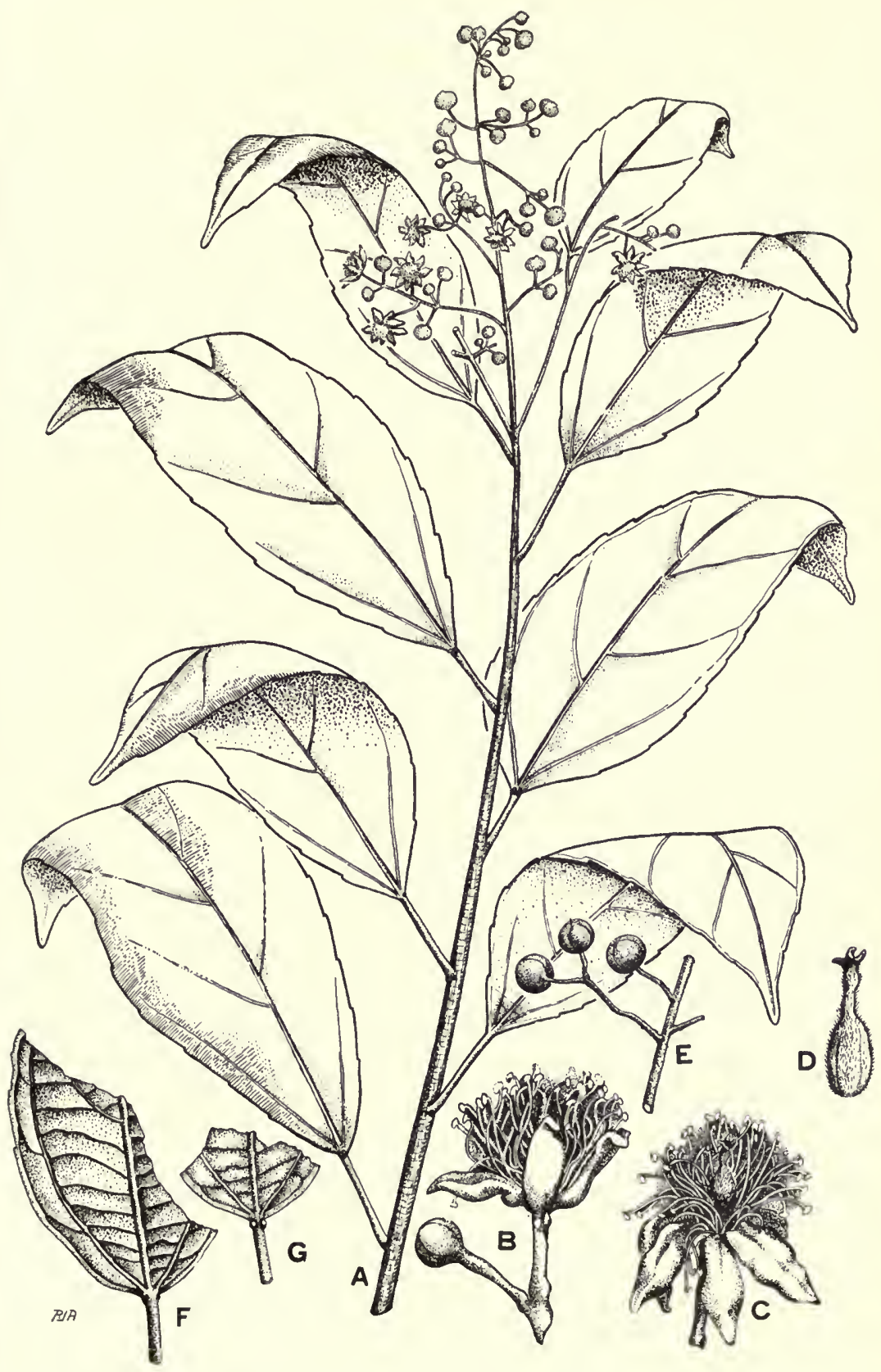

FIG. 12. Pleuranthodendron mexicana. A, Branch with inflorescence; $\times 1 / 2$. B, Flower and bud; $\times 3$. C, Flower opened out; $\times 3$. D, Immature ovary; $\times 6$. E, Fruits; natural size. F, Under surface of leaf, showing detail of veins and nerves; natural size. G, Upper surface at base of leaf, showing glands; natural size. 
scarcely dehiscent, covered with a dense, minute, gray or white tomentum, subglobose, 5-6 mm. long.

This tree is often plentiful in lowland forests, forming a considerable part of the forest understory. It is called "guatuso" in Honduras and "pochitoquillo" in Veracruz. The bark is dark brown and thin; wood yellowish throughout, rather hard, easy to work and saw.

This species has been reported as both Hasseltia dioica (Benth.) Sleumer and Hasseltiopsis dioica (Benth.) Sleumer, an error for which Sleumer is responsible. He assumed that Banara dioica Benth. and Banara mexicana Gray were synonymous, when, in fact, they do not belong to the same genus; the first belongs to Banara and the second to Pleuranthodendron.

\section{PROGKIA L.}

Shrubs or small trees; stipules of ten large and foliaceous; petiole usually bearing 2 glands at the apex; leaves membranaceous, serrate, 3-5 (-7) -nerved at the base, penninerved above base; inflorescence fasciculate or short-racemose, terminal; sepals 3-4, valvate, persistent; petals as many as the sepals or fewer, smaller than the sepals, persistent, sometimes none; stamens numerous, free, inserted on a small disk, the anthers small, subglobose; ovary 3-5-celled, many-ovulate, the style subulate, entire, fruit baccate, indehiscent, many-seeded; seeds small, obovoid, surrounded by pulp, with crustaceous testa; endosperm carnose; embryo straight, the cotyledons ovate, the radicle straight.

About 10 species, in tropical America. One additional species has been described from Costa Rica and one from Mexico.

\section{Prockia crucis L. Syst. Nat. ed. 10. 1074. 1759. Cajetillo.}

Moist or dry forest or thickets, sometimes in second growth, 2,400 meters or less; Izabal; Petén; Alta Verapaz; Jalapa; Jutiapa; Santa Rosa; Escuintla; Guatemala; Sololá; Suchitepéquez; Quiché; Huehuetenango. Western and southern Mexico; British Honduras to Panama; West Indies; South America.

Usually a shrub of 2-4 meters, sometimes a tree of 6 meters, with slender branches; stipules large, green, semicordate, dentate; leaves slender-petiolate, membranaceous, broadly ovate to elliptic or rounded-ovate, mostly $3-12 \mathrm{~cm}$. long, acute or acuminate, rounded or shallowly cordate at the base, coarsely or finely serrate, pilose or glabrate; pedicels slender, fasciculate or in short racemes; sepals $3-4$, reflexed in anthesis, about $5 \mathrm{~mm}$. long, broadly ovate, tomentose within; petals usually reduced or none; stamens very numerous, yellow, glabrous; fruit 3-5-celled, subglobose, $6 \mathrm{~mm}$. broad, black at maturity, sparsely pilose.

The wood is brittle and medium hard. Called "quesadilla" in Honduras and "cacho de novillo" in El Salvador. The species has a wide range and is variable, but attempts thus far made to segregate some of the forms as species have not been successful. 


\section{XYLOSMA Forster}

Dioecious or sometimes polygamodioecious shrubs or trees, usually armed with spines, the trunks often bearing large, stout, branched spines or thorns; leaves dentate or sometimes entire; flowers very small, whitish or green, usually unisexual; inflorescence glomerate, fasciculate or short-racemose, in leaf axils or on short pseudo-branches; sepals 4-5, usually small and scale-like, imbricate, often ciliate; petals none; stamens several to many, often surrounded with a glandular disc or interspersed with glandular staminodes; anthers short, versatile; ovary inserted upon a glandular, annular disk, the placentae 2 , or rarely 3-6, parietal, the ovules 2 or few; style entire or usually divided, the stigmas dilated or not, rarely subsessile and peltate-lobate; fruit baccate, indehiscent, small, 2-8-seeded; seeds obovoid, the testa smooth, crustaceous, the cotyledons broad.

$X y l o s m a$ is a difficult genus of, usually, dioecious trees and shrubs. There are some 40 species recorded from Mexico, Central America (including Panama), and the West Indies. Perhaps less than a third of those ascribed to Central America are valid species. The genus in America is much in need of revision and no satisfactory treatment of the species for Guatemala may be written until this is done. The species are often exasperatingly variable, but this may be due in part, at least, to inadequate understanding of them. Staminate, pistillate and polygamodioecious plants apparently may differ slightly from one another, in addition to the obvious difference in the flowers. The leaves on branches without spines seem to differ somewhat from those having coarse, heavy spines and again from those having slender, needle-like spines. The presence or absence of spines is of little or no taxonomic importance except as these may affect the leaves. Leaves of two forms are found almost constantly in one species (X. anisophyllum) and occur occasionally in others. The texture of leaves varies, perhaps partly in response to the ecological situation. Pubescence, when found, is often not constant and in many cases not critical in classification.

The bark of some species of Xylosma is reported to be rich in tannin but probably is not used in Guatemala for tanning. The wood is yellowish, pinkish or brownish, fine-grained and moderately hard but is little used except as fuel. Some species of the genus have been used as hedges, for which they are highly effective even though unsightly and difficult to control.

It was found difficult to construct a workable key to even the eight species to which those in Guatemala have been reduced, probably because too many species are still maintained. The key below, as well as the treatment of the species, should be considered to be provisional. 
Leaves velutinous to pilose, at least on the lower surface.

Leaves evidently 3 -nerved at the base............... trinervium.

Leaves not evidently 3 -nerved at the base............. velutinum. Leaves glabrous (or essentially so).

Flowers borne in short racemes................... quichense. Flowers borne in fascicles.

Leaves, or most of them, borne in fascicles, usually at the ends of very short

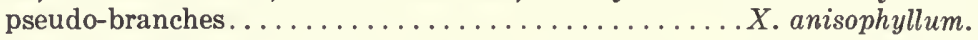

Leaves not in fascicles, scattered along the branches.

Leaf-blades lanceolate or oblong-lanceolate, usually abruptly caudateacuminate, mostly $12-15 \mathrm{~cm}$. long............. chloranthum.

Leaves mostly not as above, mostly $3-9 \mathrm{~cm}$. long.

Leaves sessile or essentially so, the petiole usually $2 \mathrm{~mm}$. or shorter, veins about 6 pairs and the nerves between them very obscure.

$X$. sessile.

Leaves with petioles more than $2 \mathrm{~mm}$. long, both veins and nerves prominent.

Leaves usually rounded or obtuse at the apex, usually very obtuse or even rounded at the base.................. celastrinum.

Leaves mostly acute or even acuminate at the apex, the base cuneate

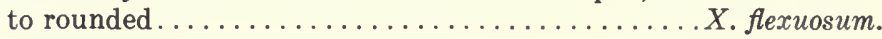

Xylosma anisophyllum Standl. Field Mus. Bot. 11: 135. 1932.

Moist or wet thickets or savannas, rarely in pine-oak forest, 1,900 meters or usually at low elevations; Petén; Alta Verapaz; Guatemala. Mexico (Campeche, the type from Tuxpeña); British Honduras; Panama.

A much-branched, stiff shrub of $1.5-2.5$ meters, or sometimes a small tree, glabrous throughout, the branches mostly unarmed but frequently bearing stout spines 1-1.5 cm. long; leaves borne in fascicles or usually so, coriaceous, on stout petioles $2-4 \mathrm{~mm}$. long, very variable upon a single plant, narrowly oblanceolateoblong to rhombic-lanceolate, obovate, or broadly elliptic-ovate, as much as $9 \mathrm{~cm}$. long and 3-5 cm. wide, obtuse or rounded at the apex, cuneate-attenuate at the base or sometimes obtuse, remotely crenate-serrate with appressed teeth or subentire, lustrous above, the veins scarcely prominulous, the veins prominulous and closely reticulate beneath; flowers numerous, in the leaf axils or at defoliate nodes, fasciculate, the slender pedicels glabrous, $5-10 \mathrm{~mm}$. long, or of ten very short; sepals oblong or lance-oblong, obtuse, $1 \mathrm{~mm}$. long, ciliate, spreading, deciduous; fruit glabrous, subglobose, 5-6 mm. long; seeds about 5, ferruginous.

This species seems reasonably distinct by reason of the fasciculated leaves which are borne on the same pseudo-branch as the fascicle of flowers. The disjunct range is of interest.

Xylosma celastrinum (HBK.) Standl. \& Steyerm. Field Mus. Bot. 23: 176. 1944. Flacourtia celastrina HBK. Nov. Gen. \& Sp. 7: 239. 1825. Putzil (Huehuetenango). 
Moist or dry, brushy plains or hillsides, sometimes on limestone, 150-1,650 meters; Jalapa; Santa Rosa; Huehuetenango. Southern and western Mexico, the type from Acapulco. British Honduras and Honduras.

A shrub or small tree of 2-6 meters, the stiff branches armed with stout, straight spines 1-2 cm. long, the whole plant glabrous throughout or nearly so; leaves on short petioles mostly $2 \mathrm{~mm}$. long or shorter, elliptic to rhombic-ovate or cuneate-obovate, mostly $3-5 \mathrm{~cm}$. long and $1.5-2.5 \mathrm{~cm}$. broad, rounded to obtuse or sometimes subacute at the apex, usually rounded or very obtuse at the base, coarsely crenate or crenate-serrate, chartaceous, often lustrous, the veins prominulous and reticulate on both surfaces; flowers fasciculate, short-pedicellate, the pedicels glabrous; sepals small, green, oblong or ovate, glabrous, white-ciliate; style very short, the stigmas short and broad; fruit subglobose, 5-6 mm. in diameter, glabrous, red or at maturity black; seeds $2-4$.

Called "aguja de arrea" in El Salvador. This species is closely allied to $X$. flexuosum (HBK.) Hemsl. and perhaps not really distinct from it. Some of the forms segregated here also are very close to $X$. anisophyllum Standl.

Xylosma chloranthum Donn.-Sm. Bot. Gaz. 57: 415. 1914 (type from Guatemala, Tuerckheim 4111). X. sylvicola Standl. Field Mus. Bot. 4: 316. 1929 (type from Honduras, Standley 52917). Santa Rosa; Alta Verapaz; Petén. British Honduras; Honduras.

A shrub or small tree, glabrous throughout, the trunk armed with large, branched spines; leaves on slender petioles 5-7 mm. long, pergamentaceous, lanceolate or lance-oblong, mostly $12-15 \mathrm{~cm}$. long and 3-4 cm. broad, narrowly caudate-attenuate or acuminate, acute or acuminate at the base, crenate-serrate, concolorous, lustrous on both surfaces, especially above; flowers numerous, fasciculate, the pedicels $2-2.5 \mathrm{~mm}$. long or longer; pistillate sepals 4 , green, $2 \mathrm{~mm}$. long, glabrous; ovary 4-celled, glabrous, the placentae 2-ovulate.

Very closely allied to the $X$. flexuosum complex but perhaps distinct.

Xylosma flexuosum (HBK.) Hemsl. Biol. Cent. Am. Bot. 1: 57. 1879. Flacourtia flexuosa HBK. Nov. Gen. \& Sp. 7: 239. 1825. Xylosma Paliurus (Clos) Briq. Ann. Cons. Jard. Génève 4: 221. 1900. Xylosma elliptica (Clos) Hemsl. Biol. Cent. Am. Bot. 1: 57. 1879. Alfiler; pico de burrion; pico de gurrión; alfilerillo; escoba blanca de montaña.

Moist or dry, often rocky thickets or mixed forest, chiefly on mountain sides or sometimes on lowland plains, occasionally in pineoak forests. Often invading overgrazed lands. Lowlands up to about 2,400 meters, in all or almost all departments. Mexico to Nicaragua and possibly to Panama and on into South America. 
Shrubs or small trees sometimes to $6 \mathrm{~m}$. tall but generally less, glabrous or sometimes the branches and leaves pubescent or puberulent, the branches stiff and stout or sometimes slender and flexuous, unarmed or armed with slender or with stout and coarse spines, the trunks commonly with large and much-branched spines or thorns; leaves mostly short-petiolate, thick-membranaceous to subcoriaceous, rhombic-ovate to elliptic-oblong or elliptic-ovate, rarely obovate, usually broadest at or below the middle, commonly acute or acuminate, the base cuneate to rounded, serrate to subentire, often lustrous, the veins usually prominent and reticulate; flowers fasciculate in the leaf axils, on glabrous or puberulent pedicels 1.5-5 mm. long; sepals oblong or narrower, obtuse or acute, spreading, glabrous or pubescent dorsally, ciliate or eciliate; fruits subglobose, 5-6 $\mathrm{mm}$. in diameter or sometimes larger, bright red when mature.

Called "aguja de arrea" and "pepenance" in El Salvador and "aguja de ara" in Honduras. This species as reported here is possibly an aggregate. Considering the present state of knowledge of this genus there seems no point in attempting to separate subspecific taxa. In the sense that the species is described here it may include as well Xylosma Hemsleyanum Standl., $X$. Seemannii Tr. \& Pl., $X$. panamensis Turcz., and possibly X. prunifolium (HBK.) Griseb. from South America. Species closely allied but kept apart in this flora are $X$. sessile Standl. \& Steyerm., $X$. chloranthum Donn.-Sm., $X$. celastrinum (HBK.) Standl. \& Steyerm., and $X$. velutinum (Tul.) Tr. \& Karst.

Hedges of this species, or a related one, are reported planted in the Jocotán region and in Jalapa, where they are called "aguja de arrea." The wood is valued there because it burns slowly and steadily.

Xylosma quichense Donn.-Sm. Bot. Gaz. 18: 197. 1893. X. quichense var. subalpinum Donn.-Sm. op. cit. 198 (type collected near El Jute, Quiché, Heyde \& Lux 3064).

Moist or wet, mixed or oak forest, 1,600-3,000 meters; endemic; Baja Verapaz; El Progreso; Jalapa; Chimaltenango; Quiché (type from San Miguel Uspantán, Heyde \& Lux 3066); Huehuetenango; San Marcos; Sololá.

A shrub or of ten a tree of 2-8 meters, rarely $12-15$ meters high, the branches unarmed or bearing rather long, slender, stiff spines, pubescent or almost wholly glabrous, the trunk usually armed with very large, stout, much-branched, brown spines; leaves short-petiolate, thick-membranaceous or subchartaceous, oblongelliptic to ovate-oblong, mostly $6-12 \mathrm{~cm}$. long, acuminate or rather abruptly so, rounded or obtuse at the base, serrate, the teeth of ten close, elongate, and incurved or salient, the veins usually prominent and reticulate, of ten lustrous; flowers racemose, the racemes solitary or fasciculate, short and few-flowered, sometimes branched; sepals 4-6, at anthesis broadly ovate, becoming elliptic-oblong, green, as much as $4 \mathrm{~mm}$. long, glabrous, not ciliate; stamens $20-35$, not exceeding the sepals; fruit globose, glabrous, 5-6 mm. in diameter, of ten bright red. 
The species is allied to the main Central American complex around Xylosma flexuosum but is easily distinguished by the broad sepals and racemose inflorescence.

Xylosma sessile Standl. \& Steyerm. Field Mus. Bot. 23: 177. 1944.

Moist or wet forest or thickets, often or perhaps usually on limestone, 1,500 meters or less; endemic; Alta Verapaz (type from Cobán, Tuerckheim II.1617; collected also in the region of Chelac); Izabal (Los Amates).

A glabrous shrub, the branches ferruginous or brown, unarmed or bearing stout spines 1-2 cm. long; leaves almost sessile, on petioles $2 \mathrm{~mm}$. long or usually shorter, coriaceous, elliptic-oblong or lance-oblong, $6.5-8.5 \mathrm{~cm}$. long, $2-3 \mathrm{~cm}$. broad, acute or short-acuminate, cuneate-acute at the base, remotely appressedserrate or almost entire, often lustrous above, the nerves prominulous, the veins obsolete, slightly paler beneath, usually brownish when dried, the lateral nerves about 6 pairs, prominulous, the veins obsolete or obscure; flowers densely fasciculate in the leaf axils, the slender pedicels 5-7 mm. long, glabrous; sepals oblongovate, $1.5 \mathrm{~mm}$. long, obtuse, glabrous, ciliate; stamens numerous, the filaments glabrous, 2.5-3 mm. long; fruit subglobose, 5-7 mm. in diameter, glabrous; style very short, the stigmas short, ovate.

This species is a part of the Central American complex which centers around $X$. flexuosum and perhaps should be referred there.

Xylosma trinervium Standl. \& Steyerm. Field Mus. Bot. 23: 178. 1944.

Known only from the type, Huehuetenango, along Río Cuilco between Cuilco and San Juan, 1,200-1,300 meters, Steyermark 50876.

A slender shrub 1.5-3 meters high, the branches tortuous, terete, brown, when young densely pilosulous with short spreading whitish hairs, unarmed; leaves small, thick-membranaceous, petioles $3-4 \mathrm{~mm}$. long, elliptic or lance-elliptic, widest near the middle, $4-5.5 \mathrm{~cm}$. long, $2-2.8 \mathrm{~cm}$. broad, acute or acuminate, cuneateacute or subobtuse at the base, conspicuously 3 -nerved from the very base, coarsely crenate or crenate-serrulate, densely velutinous-pilose on both surfaces with spreading grayish hairs, the lateral nerves about 4 pairs, ascending at a very narrow angle; flowers unisexual, the staminate in short racemes, the racemes subterminal, solitary, subsessile, densely few-flowered, about $1 \mathrm{~cm}$. long, the pedicels short, pilosulous; sepals oval or rounded, green, slightly more than $1 \mathrm{~mm}$. long, rounded at the apex, spreading, long-ciliate, sparsely pubescent or glabrous dorsally; stamens 7-8, slightly longer than the sepals, glabrous; pistillate flowers unknown.

Xylosma velutinum (Tulasne) Triana \& Karst. ex Karst. Fl. Colomb. 1: 123, t. 97. 1858. Flacourtia velutina Tulasne, Ann. Sci. Nat. ser. III, 7: 295. 1847. Myroxylon velutinum Warb. in Engler \& 
Prantl, Pflanzenfam. 3, Abt. 6a: 41. 1893. Xylosma characanthum Standl. Field Mus. Bot. 11: 136. 1932 (type from British Honduras, Bartlett 12004). Corona; copalin; tira-zapato; puntezapat; aguja rabia; aguja de ara.

Mostly in dry, rocky thickets or on forested hillsides, rarely in moist or wet places, occasionally forming large and dense thickets; Santa Rosa; Escuintla; Chimaltenango; Guatemala; Retalhuleu; Quezaltenango; Huehuetenango. Mexico; El Salvador; Honduras; Nicaragua; Costa Rica; Colombia; Ecuador.

A shrub or tree, sometimes $10 \mathrm{~m}$. tall, the trunk often armed with large, muchbranched spines or sometimes unarmed; the branches slender and flexuous to thick and stout, unarmed or armed with numerous stout to slender spines, when young densely pilosulous with pale spreading hairs or almost glabrous; leaves shortpetiolate, rather thin to coriaceous, elliptic to rounded or obovate, mostly 3.5$6 \mathrm{~cm}$. long and $2-4 \mathrm{~cm}$. broad, acuminate to very obtuse at the apex, cuneate to rounded at the base, conspicuously crenate-serrate to almost entire, densely velutinous-pilosulous on both surfaces or glabrous above and sparsely pilose to villous beneath; flowers fasciculate in the leaf axils, the pedicels usually short, pilosulous; fruit globose, 5-6 mm. in diameter, often bright red, at maturity black, usually glabrous; seeds $2-4$.

An exceedingly variable species, similar in many of its forms to those of $X$. flexuosum, to which it is closely related.

\section{ZUELANIA A. Richard}

Trees or large shrubs; leaves stipulate, pellucid-punctate, alternate, entire or serrate, pubescent, penninerved; flowers small, perfect, densely fasciculate, the pedicels articulate, bracteate at the base; calyx $4-5$-lobate, the lobes imbricate; petals none; stamens $20-40$, alternating with fleshy staminodia; ovary free, 1-celled, many-ovulate, with 3 parietal placentae; stigma sessile or subsessile, peltate; fruit large, capsular, fleshy, berry-like, at length opening by valves; seeds numerous, arillate, the endosperm carnose.

Three species, the others West Indian.

The genus is hardly distinct from Casearia.

Zuelania Guidonia (Swartz) Britton \& Millsp. Bahama Fl. 295. 1920. Laetia Guidonia Swartz, Prodr. Veg. Ind. Occ. 83. 1788. Z. Roussoviae Pittier, Contr. U. S. Nat. Herb. 18: 163, t. 79. 1916 (type from Panama). Palacio (Izabal); quacap (Alta Verapaz); tamay (Petén, Maya); trementino (Petén).

Moist or wet thickets or in open forest, often in pine forest; Petén; Izabal; Alta Verapaz. Veracruz and Oaxaca to Yucatan; British Honduras along the Atlantic coast to Panama; West Indies. 
Sometimes only a large shrub but usually a tree, of ten 10-25 meters high, the trunk $30-60 \mathrm{~cm}$. in diameter, the crown rounded or spreading, the bark light or dark grayish to very dark brown, moderately smooth, the inner bark deep pinkish, yielding a sticky transparent sap when cut; young branchlets densely brownishhirsute; leaves deciduous, often clustered at the ends of the branches, on petioles about $1 \mathrm{~cm}$. long, broadly to narrowly oblong, 15-25 cm. long, acute or acuminate, obtuse to shallowly cordate at the base, inconspicuously serrate, densely velutinous-pilose beneath, glabrate above in age and often lustrous; flowers of ten appearing before the leaves, cream-colored, in large, very dense clusters at the ends of the branchlets or in lateral clusters, the pedicels mostly 10-15 mm. long; sepals $7 \mathrm{~mm}$. long, sericeous outside, broadly rounded at the apex; stamens mostly 2025 but sometimes more, the filaments glabrous or sparsely pilose; ovary densely pilose; fruit globose, shallowly 3-sulcate, $3.5 \mathrm{~cm}$. in diameter or larger, yellowish green, with soft flesh, juicy; seeds obovoid, angulate, $4 \mathrm{~mm}$. long.

Called "water-wood" in British Honduras; "resina," "sangre de playa" (Honduras); "volador" (Yucatan); "manzano," "manzanillo," "campanillo," "tepecacao" (Oaxaca, Veracruz). The wood is yellow throughout, moderately hard, tough, fine-textured, not durable. It is little used, except in some regions for construction purposes.

\section{TURNERAGEAE}

Herbs, shrubs, or trees, glabrous or pubescent, the pubescence of simple or branched hairs; leaves alternate, petiolate, simple, usually serrate, often 2-glandular at the base; stipules small or none; flowers regular, perfect, small or large, axillary, solitary or few, sessile or pedunculate, rarely racemose, the peduncles free or connate with the petiole, often articulate, frequently 2-bracteolate; calyx tubular, 5-fid, deciduous, the lobes imbricate; petals 5, most often yellow, inserted in the throat of the calyx, membranaceous, contorted in bud, deciduous, naked or sometimes bearing a fimbriate scale at the apex of the claw; stamens 5 , inserted at the base, middle, or throat of the calyx tube, rarely hypogynous, the filaments free, complanate-subulate; anthers oblong, the cells introrsely dehiscent; ovary free, ovoid or elongate, 1-celled, the styles 3 , terminal, filiform, simple or 2-fid; stigmas flabellately multifid, rarely simply dilated; ovules numerous, 2-seriate on 3 parietal placentae, ascending, anatropous; capsule 1-celled, 3 -valvate at the apex or for its whole length, the valves bearing the placentae along their middle; seeds oblongcylindric, slightly curved, arillate, the testa subcrustaceous, foveolate; endosperm abundant; embryo terete, axile, orthotropous, the cotyledons plano-convex, the radicle terete.

Eight genera, in tropical or warm regions of both hemispheres. Only the following are represented in North America.

Flowers large, mostly 6-7 cm. long; petals bearing a fimbriate scale at the apex of the claw; stigmas entire; large trees.................... Erblichia.

Flowers much smaller; petals naked; stigmas fimbriate; herbs or low shrubs.

Receptacle of the flower bearing a corona; pubescence stellate; low herbs.

Piriqueta.

Receptacle without a corona; pubescence of simple hairs; herbs or shrubs.

Turnera. 


\section{ERBLICHIA Seemann}

Reference: Standley \& Steyermark, Notes on the American species of Erblichia, Field Mus. Bot. 22: 351-357. 1940.

Large trees; leaves alternate, petiolate, serrate; stipules minute; flowers large, yellow or orange-yellow, the peduncles articulate below the middle, 2-bracteolate, the bractlets subfoliaceous, serrate; sepals lanceolate, colored; petals hypogynous, obovate-spatulate, unguiculate, the claw bearing a fimbriate appendage at its apex; stamens 5, hypogynous, the anthers linear-oblong; ovary oblong, the styles 3 , the stigmas dilated and subclavate; capsule oblong, pubescent or glabrous, 3-valvate, many-seeded; seeds ovate-oblong, straight.

Erblichia was united to Piriqueta by Urban, and in this he was followed by Gilg in his account of the family in Natürliche Pflanzenfamilien. There seems to be adequate reason to maintain the genus. The wood in this genus is pale brownish, of medium density but hard and tough; the texture is fine, the grain straight to irregular. So far as we know no use is made of it. We have not seen the African species that have been associated with Erblichia and do not know what their status may be.

Leaves glabrous or essentially so below ................ odorata. Leaves velutinous below. ................. odorata var. mollis.

Erblichia odorata Seem. Bot. Voy. Herald 130, t. 27. 1854 (type from Panama); Piriqueta xylocarpa Sprague \& Riley, Kew Bull. 1923: 373. 1923 (type from British Honduras); E. xylocarpa Standl. \& Steyerm. Field Mus. Bot. 22: 353. 1940; E. Standleyi Steyerm. Field Mus. Bot. 22: 353. 1940 (type from Honduras). Conóp; cortez; candillaria.

Occasional in wet forest to about 900 m.; Alta Verapaz; Petén; Izabal. Mexico, Central America (except Nicaragua), and Panama.

A tall tree to $40 \mathrm{~m}$., but usually much less, with a trunk $50 \mathrm{~cm}$. in diameter; leaves short-petiolate, lance-oblong or elliptic-oblong, mostly 7-14 cm. long, acute or acuminate at each end, appressed-serrate or crenate, glabrous and lustrous above, glabrous beneath or nearly so, of ten with appressed hairs along the costa above; sepals lanceolate or linear-lanceolate, 5-5.6 cm. long, long-acuminate or caudate, usually yellow-green with salmon or pale orange margins, somewhat appressed-pilosulous outside; petals yellow, bright orange or orange-salmon, cuneate-oblong, cuspidate or caudate, $6-8 \mathrm{~cm}$. long, $3.5-4.5 \mathrm{~cm}$. broad; anthers $4-6 \mathrm{~mm}$. long; ovary glabrous to densely velutinous with short ascending stiff yellowbrown hairs.

Called "flor de fuego" in El Salvador; "butterfly tree" in British Honduras. When in flower it is an outstanding tree, covered with brilliant flowers, and often towering high above the surrounding trees. It blooms usually in March and April. 


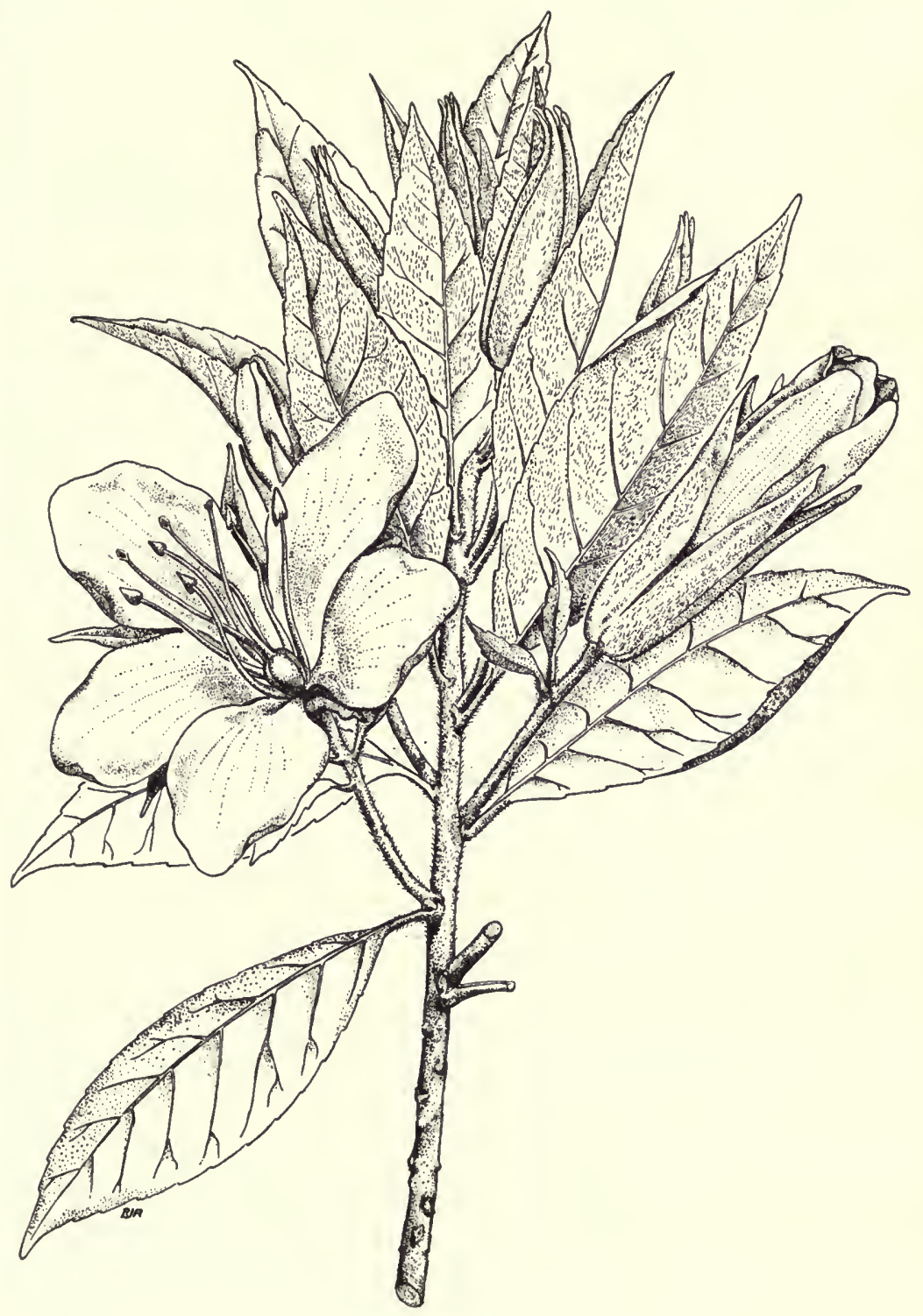

Fig. 13. Erblichia odorata var. mollis. Branch, showing open flower and buds. 
Erblichia odorata var. mollis (Standl. \& Steyerm.) L. Wms. Fieldiana: Bot. 29: 368. 1961. E. xylocarpa var. mollis Standl. \& Steyerm. Field Mus. Bot. 22: 355. 1940. Candellaria de montaña; palo de mora.

Moist highland forests, 1,200-1,500 meters; Sololá; Suchitepéquez; Quezaltenango; San Marcos. Mexico. Figure 13.

A tall tree differing from the typical variety principally in the velutinous pubescence of the under surface of the leaves.

\section{PIRIQUETA Aublet}

Usually annual herbs, abundantly stellate-pubescent, some of the hairs often simple; leaves alternate, dentate or entire, rarely pinnatifid, of ten 2-glandular at the base; flowers yellow, axillary or in greatly reduced panicles; sepals 5, imbricate in bud; petals usually yellow, sometimes purple; filaments glabrous or pubescent; anthers emarginate at the base, truncate or emarginate at the apex, rarely mucronate; stigmas 3- and 2-cleft; capsule loculicidally 3-valvate; seeds numerous, curved or almost straight, the testa roughened.

About 20 species, mostly American, a few in Asia. Probably only one occurs in Central America.

Piriqueta cistoides (L.) Mey. ex Steud. Nom. Bot. ed. 2. 2: 344. 1841. Turnera cistoides L. Sp. Pl. ed. 2. 387. 1762.

Mostly in savannas, sometimes on open rocky hillsides, 1,400 meters or less; Petén; Alta Verapaz; Chiquimula; Jalapa; Jutiapa; Huehuetenango. Mexico; British Honduras to Panama. West Indies; South America.

An erect annual or sometimes longer lived, simple or branched, the stems puberulent and also hirsute with long stiff spreading brownish hairs; leaves linearlanceolate to ovate-lanceolate, short-petiolate or the upper ones sessile, $3-9 \mathrm{~cm}$. long, acute or obtuse, obtuse or acute at the base, undulate-dentate or crenate or almost entire, usually densely stellate-pubescent on both surfaces; flowers axillary, solitary, the peduncles $3 \mathrm{~cm}$. long or shorter; sepals lanceolate, acute, $4-9 \mathrm{~mm}$. long; petals obovate, orange or yellow to almost white; filaments glabrous; capsule ellipsoid or globose, $4.5-9 \mathrm{~mm}$. long, densely short-pilose; seeds oblongobovoid, almost straight or curved, 1.5-1.8 $\mathrm{mm}$. long, foveolate-striate.

A typical savanna plant of Central America, but sometimes found in other situations. It is not at all showy, for the flowers are small and few, although they are brightly colored.

\section{TURNERA L.}

Herbs or low shrubs, the pubescence of simple hairs; leaves dentate; flowers usually yellow, solitary, axillary, often showy, the peduncles of ten adnate to the 
petioles; petals obovate or spatulate; stamens inserted below the petals, sometimes hypogynous; styles 3 , filiform, the stigmas cleft few or many times; capsule 3-valvate to the base, usually many-seeded; seeds obovoid to oblong or cylindric, curved.

Species about 60, all except two in tropical America, the others African. One species is known from Costa Rica and Panama.

Peduncles free from the petioles; shrubs, woody almost throughout.

Seeds globose-obovoid, little longer than broad. . . . . . . . . odorata.

Seeds cylindric, twice as long as broad or longer............ diffusa. Peduncles, at least most of them, adnate to the petioles, the flowers appearing to arise from the petiole; annual or perennial herbs, herbaceous or sometimes woody below.

Plants annual; flowers in dense leafy-bracted clusters at the ends of the branches.

T. Pumilea.

Plants usually perennial; flowers mostly in the axils of scattered leaves.

T. ulmifolia.

Turnera diffusa Willd. ex Schult. Syst. 6: 679. 1820. T. aphrodisiaca Ward, Virginia Med. Monthly 49. 1876. T. diffusa var. aphrodisiaca Urban, Jahrb. Bot. Gart. Berlin 2:127. 1883. Mejorana (Huehuetenango).

Mostly in dry rocky open places, sometimes on limestone or along cliffs or in pine-oak forest, 500-1,950 meters; Chiquimula; Baja Verapaz; Quiché; Huehuetenango. Mexico; British Honduras; Honduras; Nicaragua; Costa Rica; Panama; West Indies; South America.

A shrub, often densely branched, a meter high or less, usually densely pilose or pubescent throughout; leaves very variable in shape and size, oblanceolate to spatulate or oblong-ovate, mostly 1-2 cm. long, coarsely serrate or crenate, the nerves impressed above, often densely soft-pilose beneath, cuneate at the base; peduncles very short, the flowers often almost sessile; calyx 5-dentate; petals spatulate, yellow, 4-8 $\mathrm{mm}$. long, much exceeding the calyx teeth; capsule subglobose, 1.5-2 mm. in diameter.

Known in Mexico as "damiana"; "misibcoc, chac-mixib" (Yucatan, Maya). The plant is uncommon in Guatemala. In many parts of Mexico it is a common weedy plant, and it is well known there because of its reputed medicinal properties. It is particularly famed as an aphrodisiac, although it has not been proved that the plant has such properties to any great degree. It has an aromatic odor and a rather agreeable taste, and contains a volatile oil. The dried leaves are used in Mexico sometimes as a substitute for Chinese tea, for flavoring liquors and in domestic medicine for various purposes, chiefly as a tonic or for treating colds, intestinal infections and venereal diseases. The dried leaves are sold sometimes in Guatemalan markets for medicinal purposes. Quantities of the plant have been 
exported at various times to the United States and Europe for use in medicine, although it has never been an official drug, at least in the United States. The plant grows in Guatemala, so far as known, only at high elevations, but it is to be expected in the lowlands of Petén. In British Honduras it is found at or little above sea level. The species is a variable one in foliage and pubescence.

Turnera odorata L. Rich. Act. Soc. Hist. Nat. Paris 1: 107. 1792.

In pine ridge, at or little above sea level. British Honduras; South America.

A branched shrub, woody throughout, 1-2 meters high, the young branches densely short-pilose; leaves short-petiolate, ovate or broadly ovate, mostly 1.5$7 \mathrm{~cm}$. long and 1-3 cm. broad, acute or obtuse, very obtuse to cuneate at the base, coarsely crenate or crenate-serrate, densely short-pilose on both surfaces, sometimes tomentose beneath; flowers scattered in the leaf axils, of ten dimorphous, the peduncles $4 \mathrm{~mm}$. long or shorter; calyx usually $8-11 \mathrm{~mm}$. long, pubescent or glabrate, the lobes lanceolate or lance-linear; petals yellow, 6-8 $\mathrm{mm}$. long; fruit globose, 4-5.5 $\mathrm{mm}$. long, pubescent; seeds globose-obovoid, $1.5 \mathrm{~mm}$. long, longitudinally striate.

The shrub appears to be common in the pinelands of British Honduras, but it is not known in other parts of the North American mainland.

Turnera Pumilea L. Syst. ed. 10. 965. 1759.

Open, usually dry and rocky, grassy or brushy slopes, sometimes in pine forest, 400-1,200 meters; Zacapa; Chiquimula; Jalapa; Jutiapa; Huehuetenango. British Honduras; Honduras; Nicaragua; Mexico; West Indies; South America.

An erect or decumbent annual or perennial, the stems 10-25 cm. long, usually branched from the base and of ten also above, hirsute; leaves short-petiolate, obovate or oblanceolate to ovate or ovate-lanceolate, mostly $2-5 \mathrm{~cm}$. long, acute or subacute, cuneate at the base, coarsely serrate, hirsute with long spreading hairs; flowers crowded in many-flowered dense clusters at the ends of the branches, the clusters very densely hirsute; calyx 6-7 $\mathrm{mm}$. long; petals slightly longer than the sepals, yellow; seeds obovoid-oblong, curved, the testa deeply foveolate.

In Mexico the perennial phase of this species has been described as Turnera Palmeri S. Wats.

Turnera ulmifolia L. Sp. Pl. 271. 1753. Tapalayote (Baja Verapaz); escoba, malva cimarrona (Petén, fide Lundell).

Savannas or stony fields or hillsides, often on open banks or a weed in waste ground, sometimes on limestone, 1,200 meters or less; 
Izabal; Petén; Alta Verapaz; Baja Verapaz; El Progreso; Zacapa; Chiquimula; Jutiapa; Escuintla; Guatemala; Huehuetenango. Mexico; British Honduras to El Salvador and Panama; West Indies; South America.

An erect herb or shrub, usually $75 \mathrm{~cm}$. high or less, densely pilose throughout with pale, spreading or sometimes appressed hairs; leaves petiolate, lanceolate to oblong-ovate, mostly $3-10 \mathrm{~cm}$. long, acute or acuminate, usually attenuate to the base and conspicuously 2-glandular, serrate or crenate-serrate; peduncles united with the petiole, the flower thus appearing to be sessile on the petiole; calyx deeply 5-lobate, the segments lanceolate, acute to long-acuminate; petals deep or bright yellow, 1-3 cm. long; capsule 6-10 mm. long, 3 -valvate above or almost to the base, densely pilose; seeds short-cylindric, ochraceous, densely foveolate.

Known in El Salvador by the names "flor de San Lorenzo," "escobillo," and "escobillo blanco;" "clavel de oro," "calendula" (Yucatan). The plant is showy when in full flower, but in general it is rather weedy. Through its wide range it exhibits a great deal of variation, but the Guatemalan material is fairly uniform.

\section{PASSIFLORACEAE. Passion-flower Family}

References: E. P. Killip, Passifloraceae of the Mayan region, Carnegie Inst. Wash. Publ. 461: 301-328, t. 1, 2. 1936; The American species of Passifloraceae, Field Mus. Bot. 19: 1-613. 1938.

Scandent herbs or shrubs, with tendrils, or rarely erect shrubs or trees; leaves alternate, simple, entire or lobate, very rarely compound, the petiole usually bearing glands; stipules 2, filiform to ovate; peduncles usually geniculate; bracts and bractlets 3, small and distant from the flower, or large, foliaceous, and close to the flower and forming a kind of involucre; tendrils axillary, not branched; flowers axillary, perfect or rarely unisexual, regular, solitary, cymose-racemose or cymosepaniculate; calyx tube receptacle almost flat to saucer-shaped or campanulate, bearing in the center a gynophore; sepals 5 , inserted in the throat of the receptacle, imbricate, often with a small horn-like process dorsally near the apex, usually colored inside; petals none or as many as the sepals and alternate with them, free, imbricate, withering, persistent; corona present, inserted in the throat or tube of the receptacle, 1-several-seriate, divided into radiate or erect filaments, sometimes membranous or wanting; stamens mostly 5; ovary superior, free, stipitate, 1-celled; style simple or with 3-4 branches or the styles usually 3 ; ovules generally numerous, pendulous, attached to 3 or 5 parietal placentae; fruit more or less baccate, or sometimes capsular and opening by 3 apical valves; seeds numerous, usually ovoid, compressed, covered with a fleshy aril or surrounded by pulp; endosperm carnose; embryo rather large, the cotyledons often foliaceous; radicle straight.

About a dozen genera, in both hemispheres. Most of the members of the family belong to the genus Passiflora. Three other genera are known from tropical America, but only one of them, Tetrastylis, extends to Central America (Costa Rica). 


\section{PASSIFLORA L. Passion-flower}

Herbaceous or woody vines or rarely erect shrubs or small trees; leaves alternate, petiolate, simple or compound, often lobate; inflorescences axillary, simple or compound; bracts small and remote from the flower or large and surrounding the flower as an involucre; flowers perfect; calyx tube patelliform to campanulate or cylindric; sepals fleshy or membranaceous, often corniculate or aristate dorsally just below the apex; petals 5 , membranous, sometimes wanting; corona of 1 -several series of distinct or more or less united filaments, rarely tubular; operculum borne within or below the corona, membranous, flat or plicate, entire, lacerate, or filamentose, rarely wanting; stamens 5 , the filaments united to form a tube, this closely adnate to the gynophore, the free filaments erect at first, at length reflexed, attached dorsally to the anther near its middle; anthers linear, ovate, or oblong, 2-celled; ovary globose, ovoid, or fusiform, borne on a gynophore, this usually elongate; styles 3 , distinct or united at the base, cylindric or clavate; stigmas capitate, orbicular, or reniform; fruit indehiscent, containing mucilaginous pulp; seeds more or less compressed, reticulate, punctulate, or transversely grooved, borne on 3 parietal placentae.

More than 350 species are known from tropical America, and a few others occur in Asia and Australia. Two species extend into temperate regions of the United States. The plants of this genus are easily recognized by their distinctive flowers, of rather complicated and curious structure. The early Spanish explorers, as well as some of the scientists of their day, were greatly impressed by a fancied resemblance between the design of the flower and the emblems associated with the Crucifixion; hence the Spanish name "pasionaria" applied to the plants, and the Latin term "Passiflora" given to the genus. Many of the species are notable for their handsome and showy flowers. The fruits of all species probably are edible. Some of the larger ones have excellent quality and flavor, but the smaller fruits usually are insipid and seldom are eaten.

\section{Key to Passiflora}

Bracts of the peduncles at least $8 \mathrm{~mm}$. wide, forming an involucre at the base of the flower, entire or pinnatisect; flowers usually more than $4 \mathrm{~cm}$. broad when expanded, often highly colored.

Bracts 2-4 times pinnatisect, the segments filiform, gland-tipped.

Leaves not lobate, coriaceous or subcoriaceous, the nerves impressed on the upper surface....................... Urbaniana.

Leaves lobate, usually membranaceous, the nerves not impressed.

Petals linear, more than twice as long as the outermost filaments of the corona; gynophore at least $2 \mathrm{~cm}$. long. . . . . . . . . P. Palmeri.

Petals oblong or oblong-lanceolate, less than twice as long as the outermost filaments of the corona; gynophore less than $2 \mathrm{~cm}$. long...P. foetida.

Bracts entire.

Leaves deeply lobate, the lobes extending to the middle of the blade or lower.

Lobes of the leaves obtuse. 
Leaves 3-lobate....................... subpeltata.

Leaves 5 -lobate.............................. caerulea

Lobes of the leaves very acute or acuminate.

Stipules conspicuous, semiovate.......... Oerstedii var. choconiana.

Stipules setaceous or linear, inconspicuous.

Bracts united for much of their length . ........... platyloba. Bracts free.

Lobes of the leaves merely acute; bracts $2-2.5 \mathrm{~cm}$. long . . P. edulis. Lobes of the leaves cuspidate-acuminate; bracts $5 \mathrm{~cm}$. long.

P. prolata.

Leaves not at all lobate or only very shallowly so.

Leaves peltate.

Bracts usually purplish; leaves orbicular in outline, obscurely 3-lobate at

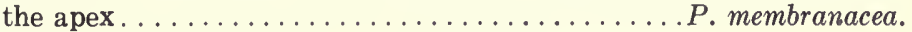

Bracts green; leaves broadly ovate in outline.

Stipules crenate; bracts more than $3 \mathrm{~cm}$. long, entire......P. Cookii.

Stipules setiferous-dentate; bracts less than $3 \mathrm{~cm}$. long, denticulate toward the base........................ Hahnii.

Leaves not peltate.

Stems acutely 4-angulate, winged on the angles.....P. quadrangularis.

Stems neither angulate nor winged.

Leaf blades as broad as long or much broader, lunately bilobed or shallowly 3-lobate at the broad apex.

Leaves densely velutinous-pubescent, shallowly 3-lobate.

$P$. porphyretica.

Leaves glabrous or nearly so, lunately bilobate.......P. pulchella.

Leaf blades much longer than broad, not at all lobate, acute or acuminate.

Leaves densely pubescent beneath.

Stipules linear-subulate; leaves usually serrulate...P. serratifolia. Stipules semiovate; leaves entire............ Oerstedii.

Leaves glabrous or practically so.

Leaf blades obtuse or rounded at the base......... a ambigua. Leaf blades conspicuously cordate at the base.

Glands of the petiole liguliform or filiform, at least $3 \mathrm{~mm}$. long. P. ligularis.

Glands of the petiole saucer-shaped..........P. Nelsonii.

Bracts of the peduncles often absent, when present not involucrate, usually setaceous and scattered along the peduncle, not forming an involucre; flowers rarely more than $4 \mathrm{~cm}$. broad when expanded, often much smaller, not highly colored.

Petioles bearing conspicuous glands.

Leaves peltate.

Leaf blades transversely oblong-elliptic, much broader than long, green beneath; peduncles not more than $1.5 \mathrm{~cm}$. long.........P. coriacea.

Leaf blades subrotund, about as long as broad, glaucous beneath; peduncles more than $1.5 \mathrm{~cm}$. long................... clypeophylla. 
Leaves not peltate.

Leaves not lobate, entire. P. obovata.

Leaves shallowly or deeply lobate, often also dentate.

Stipules linear or filiform.

Terminal lobe of the leaf acute or acuminate.......... suberosa.

Terminal lobe of the leaf rounded or very obtuse.....P. holosericea. Stipules semiovate or ovate.

Petals none; leaves glabrous, the lobes long-acuminate...P. trinifolia.

Petals present; leaves usually pubescent, the lobes mostly obtuse or somewhat acute.

Bracts more than $3 \mathrm{~mm}$. broad, laciniate or irregularly lobate. Bracts laciniate; fruit globose ............... adenopoda. Bracts irregularly few-lobate; fruit narrowly obpyriform.

Bracts narrow, entire.

P. dolichocarpa.

Glands borne near the middle of the petiole .......P. sicyoides. Glands borne near the apex of the petiole or at least in its upper third............................... morifolia.

Petioles without glands.

Leaves glabrous or very minutely pubescent; bracts usually present.

Bracts none; peduncles very slender, widely spreading, more than $4 \mathrm{~cm}$.

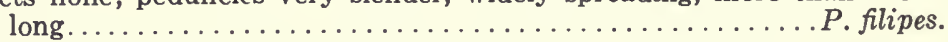

Bracts present though often deciduous in age; peduncles stouter, usually less than $4 \mathrm{~cm}$. long.

Peduncles 3-flowered; leaves 2-lobate to the middle.....P. allantophylla. Peduncles 1-flowered.

Leaves truncate or usually somewhat angulately and very shallowly 3-lobate ac the apex..................... Helleri.

Leaves deeply or shallowly 2-lobate at the apex.

Sepals 7-8 mm. long; corona filaments in a single series.

P. ornithoura.

Sepals 9-20 mm. long; corona filaments in 2 series.

Leaves 2-lobate to below the middle, the lobes erect or nearly so.

$P$. macrostemma.

Leaves very shallowly 2-lobate or, if deeply 2-lobate, the lobes widely spreading....................

Leaves usually densely and conspicuously pubescent with short or rather long hairs; bracts none.

Leaves not at all lobate, acute or acuminate.

Corona filaments linear-clavate; leaves attenuate-acuminate, finely pilos-

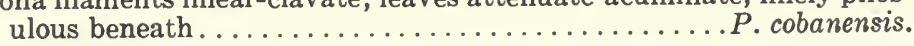

Corona filaments subulate; leaves acute or acuminate, densely villouspubescent beneath. ....................... brevipes.

Leaves more or less lobate, usually conspicuously so.

Peduncles bearing more than 1 flower............... sexflora.

Peduncles 1-flowered.

Stems and leaves hirsute with brownish hairs; leaf blades rounded at the base................................. costaricensis. 
Stems and leaves with short grayish hairs, or tomentulose.

Leaf blades much longer than broad, deeply cordate at the base, the short lobes suberect................... Rovirosae.

Leaf blades mostly broader than long, very shallowly or usually not at all cordate at the base, the lobes divergent.

Peduncles solitary; outer corona filaments $12-15 \mathrm{~mm}$. long.

$P$. capsularis.

Peduncles geminate; outer and inner corona filaments about $2 \mathrm{~mm}$.

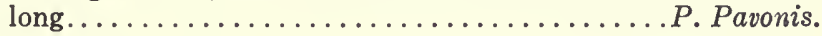

\section{Passiflora adenopoda DC. Prodr. 3: 330. 1828.}

Dense, wet, mixed forest, ranging from about 2,700 meters almost down to sea level; Petén; Alta Verapaz; Santa Rosa; Quezaltenango; San Marcos. Southern Mexico; British Honduras; Costa Rica and Panama; Colombia to Peru.

A large herbaceous vine, the stems hispidulous or glabrate; stipules semiorbicular, $1 \mathrm{~cm}$. long and $1.5 \mathrm{~cm}$. broad, entire or dentate; petioles $3-5 \mathrm{~cm}$. long, bearing 2 opposite orbicular glands $2-4 \mathrm{~mm}$. in diameter about $8 \mathrm{~mm}$. from the base of the blade; leaf blades 7-12 cm. long, 7-15 cm. broad, 3-5-lobate, the lobes ovate, abruptly acuminate, cordate at the base, entire or remotely denticulate, hispidulous on both surfaces or glabrate; peduncles solitary or geminate, $2-2.5 \mathrm{~cm}$. long; bracts 3 , inserted at the middle of the peduncle, lanceolate or oblong, 7-10 $\mathrm{mm}$. long, 4-6 $\mathrm{mm}$. broad, lacerate; flowers $2-7 \mathrm{~cm}$. broad, the sepals oblonglanceolate, 2-4 cm. long, $1 \mathrm{~cm}$. broad, obtuse, terminating in a horn-like appendage $1 \mathrm{~cm}$. long, greenish white or yellowish; petals linear-lanceolate, 10-12 mm. long; corona filaments uniseriate, filiform, $15-18 \mathrm{~mm}$. long, white with purple bands; ovary densely brown-tomentose; fruit globose, $2-2.5 \mathrm{~cm}$. in diameter; seeds obcordate, $6 \mathrm{~mm}$. long, $4 \mathrm{~mm}$. broad, straw-colored, reticulate.

Passiflora allantophylla Masters in Donn.-Sm. Bot. Gaz. 16: 7. 1891.

Known only from the type, Santa Rosa, Baja Verapaz, 1,500 meters, Tuerckheim 1425.

Plants glabrous throughout; stipules setaceous, 1.5-2 mm. long, deciduous; petioles 5-10 mm. long, eglandular; leaf blades $2-2.5 \mathrm{~cm}$. long, $4-5 \mathrm{~cm}$. broad, 2-lobate to the middle, the lobes rounded, mucronate, somewhat divergent, the blades entire, rounded at the base, bearing 1-2 pairs of ocellae on the lower surface; peduncles slender, equaling or slightly exceeding the petioles, 3-flowered, the pedicels very slender, about equaling the peduncles; bracts setaceous, deciduous; flowers 10-12 mm. broad, white; sepals oblong, 5-7 mm. long, 2-2.5 mm. wide, obtuse; petals hyaline, slightly shorter than the sepals; corona filaments uniseriate, $2 \mathrm{~mm}$. long, capitellate; ovary subglobose, glabrous.

Passiflora ambigua Hemsl. Bot. Mag. 128: t. 7822. 1902.

Wet, mixed forest or thickets, 500 meters or less; Alta Verapaz; Izabal. Southern Mexico; British Honduras to Panama. 
A large, often somewhat woody vine, glabrous throughout, the stems terete: stipules filiform, 5-8 mm. long, deciduous; petioles $2-3 \mathrm{~cm}$. long, bearing at or below the middle 2 sessile flattened glands; leaf blades oblong-lanceolate or ovatelanceolate, 10-20 cm. long, 5-9 cm. broad, short-acuminate, rounded or cuneate at the base, penninerved, coriaceous, lustrous, entire; peduncles 4-7 cm. long; bracts ovate, 3-6 cm. long, 3-4 cm. broad, entire, eglandular; flowers 8-12 cm. broad, the calyx tube cylindric-campanulate, $1 \mathrm{~cm}$. long; sepals narrowly linearoblong, 4-5 cm. long, 1.5-1.8 cm. broad, obtuse, short-corniculate dorsally just below the apex, fleshy, white outside, pale pink and purple puncticulate within; petals linear-lanceolate, 3-4 $\mathrm{cm}$. long, 9-10 $\mathrm{mm}$. broad, white, dotted with rosepurple; corona filaments about 5-seriate, the outermost 1-1.5 cm. long, red, banded with white; gynophore slender, 1.5-2 cm. long; ovary narrowly ovoid, densely brown-tomentose; fruit ovoid, 10-12 cm. long, 4-4.5 cm. broad, greenish yellow; seeds ovate-oblong, 6-7 mm. long, 5-6 mm. broad, reticulate.

Called "granadilla" and "granadilla de monte" in Honduras. The name "granadilla" is given commonly in Guatemala and Central America to most species of Passiflora. La Granadilla is a caserio of the Department of Quezaltenango, Guatemala.

Passiflora biflora Lam. Encycl. 3: 36. 1789. P. lunata var. costata Masters in Mart. Fl. Bras. 13, pt. 1:552. 1872. P. Brighami Wats. Proc. Amer. Acad. 21: 473. 1887 (type from Río Chocón, Izabal, S. Watson 97). P. transversa Masters in Donn.-Sm. Bot. Gaz. 16: 7. 1891 (type from Masagua, Escuintla, J. D. Smith 2099). Granadilla; murciélago; ala de murciélago; xiczotz (Petén, Maya).

Dense, mixed, wet to rather dry forest or thickets, 2,500 meters or less, usually at 1,000 meters or lower; Petén; Alta Verapaz; Izabal; Escuintla; Retalhuleu; Quezaltenango; San Marcos; probably in all the lowland departments. British Honduras to El Salvador and Panama. Bahamas; Colombia and Venezuela.

A small or large vine, herbaceous or perhaps at times suffrutescent, the stems glabrate; stipules linear-subulate, $1.5-3 \mathrm{~mm}$. long; petioles 5-10 $\mathrm{mm}$. long or sometimes longer, eglandular; leaf blades very variable in outline, transversely linear or oblong to rounded-obdeltoid, $10 \mathrm{~cm}$. long and broad or smaller, sometimes 2-lobate, the lobes lanceolate to obovate, acute to rounded at the apex, the blades rounded or subcordate at the base, 3-nerved, reticulate-veined, glabrous above, glabrous or minutely puberulent beneath, ocellate with about 4 pairs of ocellae, coriaceous or subcoriaceous or of ten membranaceous; peduncles geminate, commonly 10-12 mm. long, articulate slightly above the middle; bracts setaceous, $2 \mathrm{~mm}$. long; flowers $2.5-3.5 \mathrm{~cm}$. broad; sepals ovate-lanceolate, 9-12 mm. long, obtuse, green outside, puberulent or glabrate, white and glabrous within; petals $8 \mathrm{~mm}$. long, $5 \mathrm{~mm}$. broad, white; corona filaments biseriate, the outer ones yellow, $7 \mathrm{~mm}$. long, the inner filiform, $5 \mathrm{~mm}$. long; ovary subglobose or ovoid, terete or angulate, glabrate to densely tomentose; fruit globose, 1-2 cm. in diameter, glabrous to densely puberulent; seeds obovoid, $2.5-3 \mathrm{~mm}$. long, with 6-7 transverse ridges. 
Called "media-luna" in Honduras and sometimes "calzoncillo" in El Salvador.

Passiflora brevipes Killip, Carnegie Inst. Wash. Publ. 461: 312, t. 2. 1936.

Moist or wet forest or thickets, 150-700 meters; Alta Verapaz (Cerro Chinajá, Steyermark 45674). Type from Jacinto Hills, British Honduras, W. A. Schipp 1304.

A large vine, densely and finely velutinous-pilosulous throughout, almost tomentulose on the leaves, the stems triangular; stipules linear-lanceolate, $5-7 \mathrm{~mm}$. long, coriaceous, persistent; petioles $8-10 \mathrm{~mm}$. long, eglandular; leaf blades ovatelanceolate or oblong-ovate, $5-8 \mathrm{~cm}$. long, $2.5-4 \mathrm{~cm}$. broad, acute or acuminate, shallowly cordate at the base, entire, 3-nerved, conspicuously reticulate-veined, subcoriaceous; peduncles geminate on the main stem or on short, axillary, almost leafless branches $4-5 \mathrm{~cm}$. long, the pedicels $4-5 \mathrm{~mm}$. long, ebracteate; sepals linear, $8-9 \mathrm{~mm}$. long, the flowers $1-1.5 \mathrm{~cm}$. broad, pale green; petals narrowly linear, $3-4 \mathrm{~mm}$. broad; corona filaments uniseriate, subulate, $2.5-3 \mathrm{~mm}$. long; ovary narrowly ovoid; fruit ovoid, $4 \mathrm{~cm}$. long, $2 \mathrm{~cm}$. broad, attenuate at the base, short-stipitate, 6 -angulate; seeds ovate, $4-5 \mathrm{~mm}$. long, $2 \mathrm{~mm}$. broad, with $6-7$ smooth transverse ridges, black, lustrous.

\section{Passiflora caerulea L. Sp. Pl. 959. 1753.}

Native from Brazil to Argentina; often grown in other regions for ornament or for its fruit; rarely cultivated in Guatemala.

Plants glabrous and often glaucous; stipules semiovate and subreniform, 1-2 cm. long, remotely dentate or subentire; petioles $1.5-4 \mathrm{~cm}$. long, bearing $2-4$ or rarely 6 stipitate glands; leaf blades generally palmately 5 -lobate about two-thirds their length, the lobes linear-oblong to ovate-oblong, obtuse or emarginate, entire, 2-4-glandular in the sinuses, the blades cordate at the base, membranaceous; peduncles $3-7 \mathrm{~cm}$. long, eglandular; bracts broadly ovate to ovateoblong, 1.5-2.5 $\mathrm{cm}$. long, 1-1.5 cm. broad, rounded at the apex, pale green; flowers as much as $10 \mathrm{~cm}$. broad, the calyx tube cupular; sepals lance-oblong or oblong, 1.5-2 cm. long, obtuse, subcoriaceous, green outside, white or pinkish within, faintly carinate dorsally, the keel terminating in a slender awn as much as $5 \mathrm{~mm}$. long; petals oblong, $1.5-2.5 \mathrm{~cm}$. long, obtuse, white or pinkish; corona filaments 4 -seriate, equaling or shorter than the petals, the outer ones blue at the apex, white at the middle, purple at the base; ovary pruinose; fruit ovoid or subglobose, about $6 \mathrm{~cm}$. long and $4 \mathrm{~cm}$. broad, orange or yellow; seeds obcordate or cuneate, $5 \mathrm{~mm}$. long, $3.5-4 \mathrm{~mm}$. broad, coarsely reticulate.

\section{Passiflora capsularis L. Sp. Pl. 957. 1753.}

Moist or wet forest or thickets, 500-2,200 meters; Chiquimula; Jalapa; Santa Rosa. British Honduras to El Salvador and Costa Rica; Greater Antilles; Colombia to Paraguay. Figure 14.

A small or rather large, herbaceous vine, the stems 3-5-angulate, glabrate or pubescent; stipules linear-subulate, 5-7 mm. long; petioles 1-3 cm. long, eglan- 
dular; leaf blades 2-7 cm. long along the costa, 4-10 cm. broad, shallowly bilobate, the lobes lanceolate or broader, acute or obtuse, the sinus acute or broad and shallow, the blades shallowly cordate, 3-nerved, pilosulous or glabrate above, paler beneath and densely pubescent; peduncles solitary, 1-6 $\mathrm{cm}$. long, articulate about $1 \mathrm{~cm}$. from the apex; bracts none; flowers 2-6 cm. broad, greenish white or pale yellow-green; sepals linear-lanceolate, 1-3 cm. long, acute, pilose dorsally; petals narrowly oblong-lanceolate or subspatulate, 6-15 $\mathrm{mm}$. long, obtuse; corona filaments 1-2-seriate, the outer ones filiform, 12-15 $\mathrm{mm}$. long, united at the base to form a thin transparent membrane, violet, the inner ones barely $3 \mathrm{~mm}$. long; ovary obovoid or narrowly obovoid, minutely puberulent, 6 -angulate; fruit ellipsoid or fusiform, sharply 6 -angulate, $5-6 \mathrm{~cm}$. long, 1.5-2 cm. broad; seeds ovate, $3.5 \mathrm{~mm}$. long, transversely sulcate, with 5-6 smooth ridges.

\section{Called "calzoncillo" in El Salvador.}

Passiflora clypeophylla Masters in Donn.-Sm. Bot. Gaz. 16: 6. 1891.

Known only from the type, Alta Verapaz, Barranco de Rubelcruz, 750 meters, Tuerckheim 1625.

Plants glabrous throughout; stipules narrowly linear, $5 \mathrm{~mm}$. long, coriaceous; petioles $2-3 \mathrm{~cm}$. long, bearing at the middle 2 sessile glands $1 \mathrm{~mm}$. in diameter; leaf blades subrotund or obscurely trilobate, $7-8 \mathrm{~cm}$. long, 8-10 cm. broad, peltate, 5-7-nerved, reticulate-veined, entire or emarginate at the apex of the nerves, membranaceous, deep green above, glaucous beneath; peduncles solitary or geminate, $1.5-2.5 \mathrm{~cm}$. long, articulate at the middle; bracts early deciduous; flowers 1-1.5 cm. broad; sepals oblong, $7 \mathrm{~mm}$. long, obtuse, yellowish green; petals none; corona filaments biseriate, the outer ones filiform, $6 \mathrm{~mm}$. long, purple at the base, yellow toward the apex, reflexed, the inner ones linear-clavate, $2 \mathrm{~mm}$. long, erect; ovary globose.

Passiflora cobanensis Killip, Journ. Wash. Acad. Sci. 14: 111. 1924.

Wet forest or thickets, on limestone, 500-950 meters; endemic; Alta Verapaz (type collected between Chamá and Cobán, Harry Johnson 411; collected also between Chirriacté and Semococh).

Stems slender, finely pubescent; stipules lanceolate, subfalcate, $8-9 \mathrm{~mm}$. long, acuminate, 5-7-nerved; petioles 8-16 mm. long, eglandular, pubescent; leaf blades ovate-lanceolate or ovate-oblong, 7-10 cm. long, 2.5-3.5 cm. broad, attenuateacuminate, rounded at the base, 3-nerved, reticulate-veined, without ocellae, serrulate, membranaceous, glabrous above, finely hirtellous beneath; peduncles $1.5 \mathrm{~cm}$. long; bracts none; flowers $2.2 \mathrm{~cm}$. broad or larger; sepals linear-lanceolate, $1 \mathrm{~cm}$. long or longer, acute, pubescent outside; petals lanceolate, $5 \mathrm{~mm}$. long, obtuse; corona filaments uniseriate, linear-clavate, $2.5 \mathrm{~mm}$. long; ovary obovoid, subangulate, densely tomentulose.

Passiflora Cookii Killip, Journ. Wash. Acad. Sci. 12: 256. 1922. Cul (Quezaltenango). 


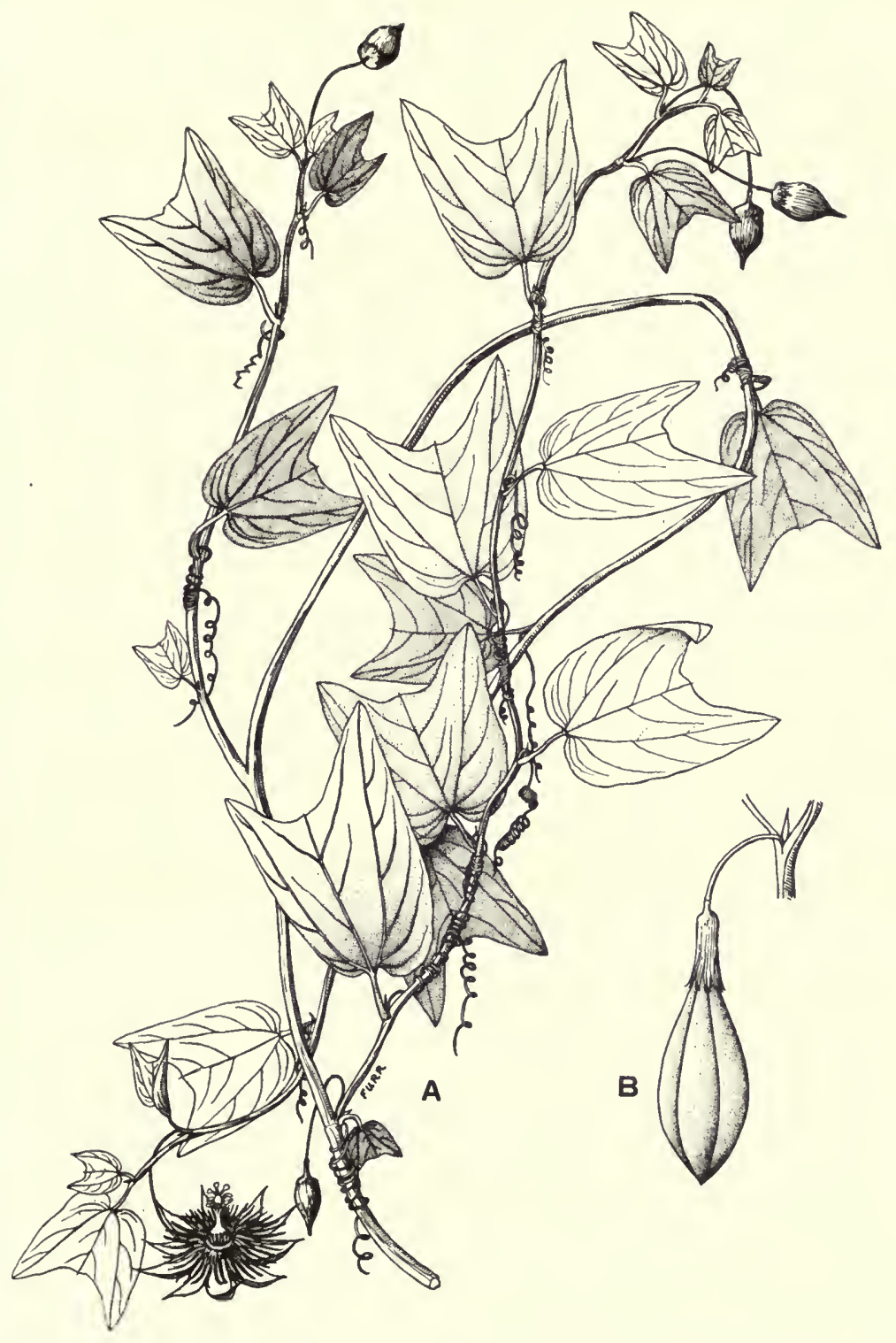

FIG. 14. Passiflora capsularis. A, Habit of plant, with flowers and buds; $\times 1 / 2$. B, Fruit; $\times 1$. 
Moist or wet, mixed forest or thickets, 1,000-2,700 meters, or perhaps even lower; Alta Verapaz (type from Sepacuite, O. F. Cook \& R. F. Griggs 593); Jalapa; Chimaltenango; Suchitepéquez; Quezaltenango; San Marcos. Mexico (Veracruz).

A small or large, glabrous vine, herbaceous throughout or nearly so, the stems glaucous; stipules reniform, $1.5 \mathrm{~cm}$. long, crenate; petioles $3-4 \mathrm{~cm}$. long, eglandular; leaf blades ovate-orbicular, 7-8 $\mathrm{cm}$. long, 6-7 $\mathrm{cm}$. broad, very obscurely trilobate, the middle lobe broadly deltoid, obtuse, mucronate, the blades peltate above the rounded or truncate base, membranaceous, 5 -plinerved, deep green above, glaucous beneath; peduncles about $8 \mathrm{~cm}$. long; bracts 2 , cordate, about $5 \mathrm{~cm}$. long and $4 \mathrm{~cm}$. broad, usually green, entire, membranaceous; flowers $3.5-4.5 \mathrm{~cm}$. broad, white; sepals ovate-lanceolate, $1.5 \mathrm{~cm}$. long, obtuse; petals ovate-lanceolate, $1.5 \mathrm{~cm}$. long, obtuse, white, spotted with purple; corona filaments biseriate, the outer ones $1 \mathrm{~cm}$. long, dilated at the apex, the inner scarcely $3 \mathrm{~mm}$. long, capitate; ovary subglobose.

This species is not very definitely separated from $P$. membranacea.

Passiflora coriacea Juss. Ann. Mus. Hist. Nat. 6: 109, t. 39, f. 2. 1805. Hoja de murciélago; ala de murciélago; granadilla de monte; media-luna; xicozotz (Petén, Maya).

Dry to wet thickets, sometimes in pine forest or mixed forest, 1,000 meters or usually lower; Petén; Alta Verapaz; Izabal; Escuintla; Suchitepéquez; Retalhuleu; probably in all the lowland departments. Mexico; British Honduras to El Salvador and Panama; South America.

Usually a small herbaceous vine; stipules narrowly linear; petioles $2-4 \mathrm{~cm}$. long, biglandular near the base, rarely glandular at the apex or 4-glandular, the glands sessile; leaf blades transversely oblong-elliptic, as much as $7 \mathrm{~cm}$. long along the costa and 7-25 $\mathrm{cm}$. broad, coriaceous to membranaceous, glabrous, usually truncate or subtruncate along the upper margin, peltate, the lateral lobes generally acute or subacute; upper inflorescence a terminal raceme devoid of leaves, bearing stipules and bract-like biglandular appendages (the petioles of abortive leaves), the lower flowers solitary or geminate in the leaf axils; flowers 2.5-3.5 cm. broad, yellowish green; sepals oblong-lanceolate; petals none; corona filaments biseriate, the outer ones filiform, the inner linear; ovary ovoid, glabrous; fruit globose, $1-2 \mathrm{~cm}$. in diameter.

The vine is well known in most parts of Central America where it goes by the name "murciélago" or some variant of that word. The unique leaves have a slight resemblance to the wing of a bat. The species is perhaps the most easily recognized of all those occurring in Central America because of the distinctive peltate leaves, much longer than broad, and sharp-pointed at the lateral tips. The Passiflora species are much used in Guatemala and other parts of Central America in domestic medicine, particularly for infections of the kid- 
neys and in general as a diuretic. This species is one of those most commonly used, and bunches of the dried stems and leaves often are on sale in the markets remote from places where the plants grow, as at Quezaltenango.

Passiflora costaricensis Killip, Journ. Wash. Acad. Sci. 12: 257. 1922.

Wet forest, 350 meters; Alta Verapaz (Cubilgüitz, Tuerckheim 7877). Atlantic coast of Honduras; Costa Rica.

Stems triangular, hirsute, at least on the angles, with long, spreading, light brown hairs; stipules subulate, 6-8 $\mathrm{mm}$. long; petioles $1.5-2 \mathrm{~cm}$. long, densely hirsute, eglandular; leaf blades oblong to ovate or rounded-ovate in general outline, 9-13 cm. long, 7-11 cm. broad, bilobate, the lobes short, deltoid, acute or acuminate, one-third the length of the blade or shorter, suberect, the terminal sinus lunate or almost semicircular, the blades rounded at the base, 3-nerved, membranaceous, hirsute, especially beneath; peduncles solitary, $1.5 \mathrm{~cm}$. long, articulate at the middle; bracts none; flowers $4.5-5 \mathrm{~cm}$. broad; sepals linear-lanceolate, $2 \mathrm{~cm}$. long, obtuse, hirsute dorsally, glabrous within, the margins hyaline; petals linear-oblong, $8 \mathrm{~mm}$. long, obtuse, hyaline; corona filaments uniseriate, narrowly ligulate, equaling the petals; ovary minutely puberulent; fruit ellipsoid, $7-8 \mathrm{~cm}$. long, $1-1.5 \mathrm{~cm}$. broad, long-attenuate at each end; seeds slightly compressed, narrowly oblong, $3 \mathrm{~mm}$. long, $1.5 \mathrm{~mm}$. broad, black, lustrous, transversely sulcate, with 6-7 smooth ridges.

Passiflora dolichocarpa Killip, Journ. Wash. Acad. Sci. 20:374. 1930.

In forest, 1,500-2,500 meters; endemic; Jalapa (between Jalapa and Montaña Miramundo); Chimaltenango (type from Chichavac, Tecpán, José García Salas 584).

Stems herbaceous, somewhat quadrangular, hispidulous; stipules semiovate, 6-7 mm. long, finely hispidulous; petioles about $2 \mathrm{~cm}$. long, biglandular below the middle or sometimes toward the apex, the glands clavate, sessile, $1.5 \mathrm{~mm}$. long; leaf blades subhastate, $6-10 \mathrm{~cm}$. long, $4.5-7 \mathrm{~cm}$. broad, trilobate, the middle lobe lanceolate to deltoid, the basal lobes reduced, acute or short-acuminate, the blades sinuate-dentate, more or less cordate at the base, membranaceous, finely hispidulous on both surfaces; peduncles geminate, $3.5-4 \mathrm{~cm}$. long, articulate near the apex; bracts ovate-lanceolate, $4-5 \mathrm{~mm}$. long, oblique at the base, sessile, irregularly lobate, hispidulous, borne on the uppermost third of the peduncle; flowers $2.5 \mathrm{~cm}$. broad, white; sepals oblong, 10-13 $\mathrm{mm}$. long, slightly cucullate at the apex, hispidulous outside, white, longitudinally streaked with red or purple within; petals oblong, $8-10 \mathrm{~mm}$. long, obtuse; corona filaments uniseriate, narrowly linear, 6-7 mm. long, white banded with red or purple; ovary ovoid, tapering at the apex, stipitate, glabrous; fruit narrowly ovoid-clavate, $6 \mathrm{~cm}$. long (including a stipe $1.5 \mathrm{~cm}$. long), $1.5 \mathrm{~cm}$. broad; seeds broadly obovate, $3-4 \mathrm{~mm}$. long, compressed, reticulate. 
Passiflora edulis Sims, Bot. Mag. 45: t. 1989. 1818. Granadilla; granadilla silvestre; granadina.

Native from Brazil to northern Argentina; often grown elsewhere for its fruit or for ornament; rarely planted in Guatemala, and perhaps naturalized occasionally. Figure 15.

Plants herbaceous, glabrous throughout or rarely pilosulous; stipules linearsubulate, $1 \mathrm{~cm}$. long, entire or minutely glandular-serrulate; petioles $4 \mathrm{~cm}$. long or shorter, biglandular at the apex, the glands sessile or short-stipitate; leaf blades 5-11 $\mathrm{cm}$. long and 4-10 $\mathrm{cm}$. broad, trilobate to below the middle, the lobes $2-4$ $\mathrm{cm}$. broad, acute or acuminate, the blades rounded or shallowly cordate at the base, serrate, rather thick; peduncles stout, $6 \mathrm{~cm}$. long or shorter; bracts ovate, 2-2.5 $\mathrm{cm}$. long, 1-1.5 cm. broad, obtuse or acute, sharply serrate, pectinatedentate, or almost lacerate, often glandular on the margins; flowers as much as $7 \mathrm{~cm}$. broad; sepals oblong, 3-3.5 cm. long, $1 \mathrm{~cm}$. broad, corniculate, green outside, white within; petals oblong, $2.5-3 \mathrm{~cm}$. long, obtuse, white; corona filaments 4-5seriate, those of the 2 outer series filiform or narrowly liguliform, $1.5-2.5 \mathrm{~cm}$. long, white, purple at the base; ovary ovoid or globose, sericeous-tomentose or glabrous; fruit ovoid or globose, 4-5 cm. long, yellow, greenish yellow, or purplish; seeds oval, 5-6 $\mathrm{mm}$. long, 3-4 $\mathrm{mm}$. broad, minutely reticulate.

This is a rare plant in cultivation in Central America. The name "granadilla silvestre" supplied by Jesús Morales Ruano for a plant collected in Guatemala would indicate that the vine was growing wild, but it seems more probable that the specimens were taken from a garden.

\section{Passiflora filipes Benth. Pl. Hartweg. 118. 1843.}

Moist or wet, mixed forest, 1,800 meters or less; Izabal; Chiquimula; Huehuetenango; Quezaltenango. Western Texas; Mexico; Honduras and El Salvador; Nicaragua; Venezuela.

Plants very slender, glabrous throughout, herbaceous, the stems terete; stipules linear-lanceolate, $2-4 \mathrm{~mm}$. long, falcate, acuminate; petioles 1-2 cm. long, eglandular; leaf blades $1-4 \mathrm{~cm}$. long, $2-6 \mathrm{~cm}$. broad, very shallowly trilobate at the apex, rounded or truncate at the base, not dentate, glaucous beneath, membranaceous; peduncles very slender, almost filiform, $4-6 \mathrm{~cm}$. long, widely spreading; bracts none; flowers $8-15 \mathrm{~mm}$. broad, yellowish green or greenish white; sepals lanceolate or linear-lanceolate, 6-9 $\mathrm{mm}$. long, subacute; petals narrowly linear, 3-4 mm. long; corona filaments biseriate, filiform, the outer ones equaling the petals, the inner ones shorter; ovary globose, glabrous; fruit globose, 5-7 mm. in diameter; seeds slightly compressed, obovate or obcordate, $4 \mathrm{~mm}$. long, $2.5-3 \mathrm{~mm}$. broad, transversely sulcate, with 3-4 interrupted ridges.

Called "sandillita de pájaro" in El Salvador.

\section{Passiflora foetida L. Sp. Pl. 959. 1753.}

A small or rather large, ill-scented, herbaceous or suff rutescent vine, glabrous or with highly variable indument; stipules semiannular, deeply cleft into filiform 


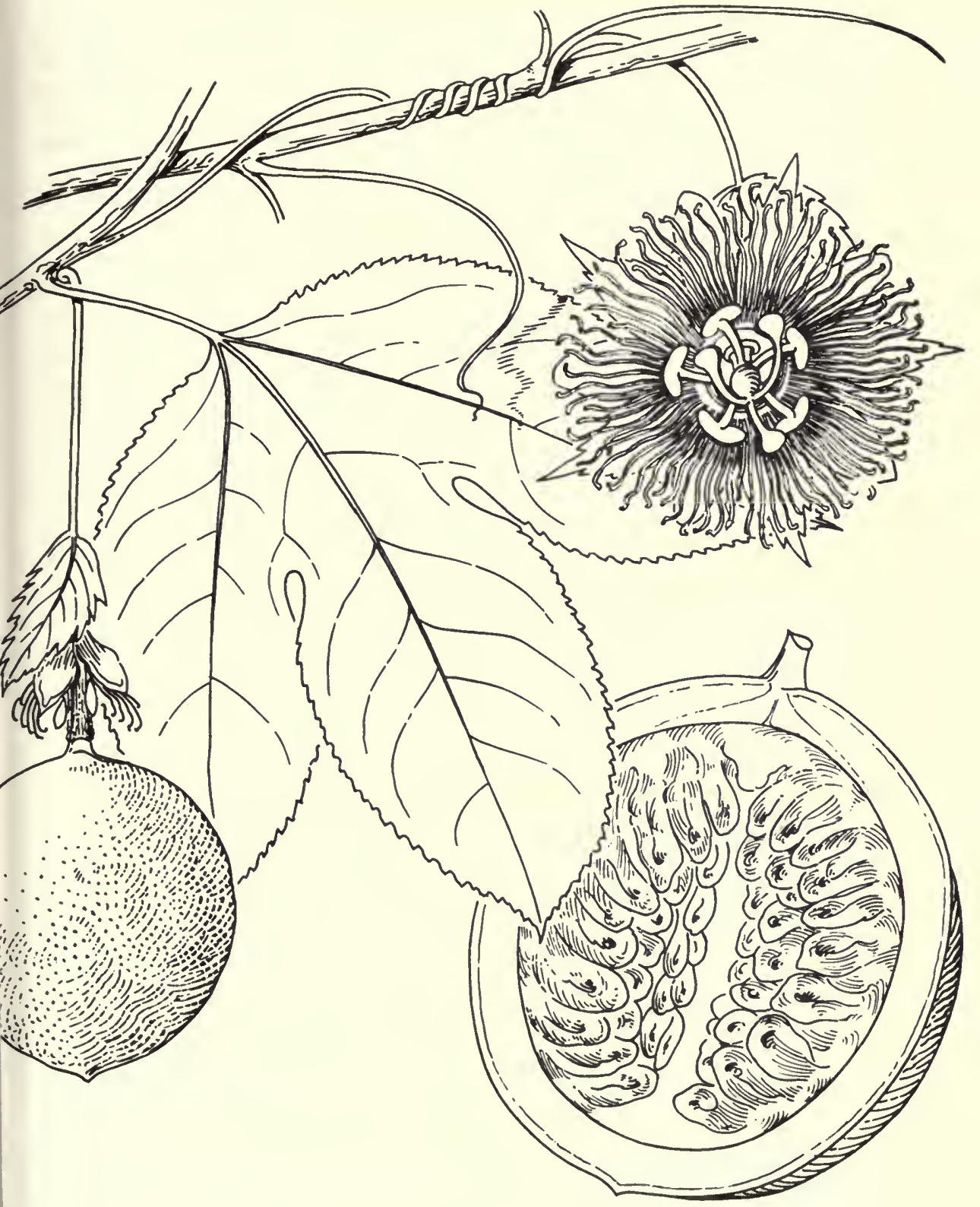

FIG. 15. Passiflora edulis. Habit, flower and fruits; reduced. 
gland-tipped divisions; petioles $6 \mathrm{~cm}$. long or less, eglandular; leaf blades cordate at the base, membranaceous, 3-5-lobate, very variable in the form of the lobes; peduncles solitary, $6 \mathrm{~cm}$. long or less; bracts forming an involucre, 2-4 times pinnatifid or pinnatisect, the ultimate divisions filiform, gland-tipped; flowers 2-5 cm. broad, white to pink, lilac, or purplish; sepals ovate-oblong or ovatelanceolate, corniculate dorsally just below the apex; petals oblong, oblong-lanceolate, or oblong-spatulate, slightly shorter than the sepals; corona filaments severalseriate, those of the 2 outer series filiform, about $1 \mathrm{~cm}$. long, the others capillary, 1-2 mm. long; fruit globose or subglobose.

The species in its various forms is distributed throughout the American tropics and has become established in some parts of the Old World. It is highly variable, and some of the forms are strikingly different, but most or many of them are connected by intergrading forms, and it has been considered more logical and practical to consider all as representing variants of a single, easily recognizable species. In his monograph of the genus Killip recognizes no fewer than 38 such varieties. Of these the following have been collected in Guatemala and British Honduras:

\section{Key to the Varieties of Passiflora foetida}

Stems glabrous or sometimes with a few scattered hairs.

Leaves glabrous.

Basal lobes of the leaves much longer than wide.......P. foetida var. ciliata. Basal lobes of the leaves slightly if at all longer than wide, or wanting.

Leaves evidently hastate-lobate, the basal lobes well developed.

$P$. foetida var. nicaraguensis.

Leaves scarcely at all lobate, the basal lobes much reduced or none.

$P$. foetida var. subintegra.

Leaves pubescent on one or both surfaces.......... foetida var. mayarum. Stems densely or rather sparsely pubescent.

Ovary hirsute................... foetida var. gossypiifolia. Ovary glabrous.

Lower surface of the leaves hirsute with short, mostly appressed hairs.

$P$. foetida var. hastata.

Lower surface of the leaves softly lanate or lanuginous, usually hirsute on the nerves with long spreading hairs.

Ultimate segments of the bracts closely interlaced; styles pilose.

$P$. foetida var. hirsutissima.

Ultimate segments of the bracts not closely interlaced; styles glabrous.

$P$. foetida var. lanuginosa.

Passiflora foetida var. ciliata (Dryand.) Masters, Trans. Linn. Soc. 27: 631. 1871. P. ciliata Dryand. in Ait. Hort. Kew. 3: 310. 1789 .

Petén (San Clemente, H. H. Bartlett 12832). Mexico (Yucatan peninsula); Jamaica. 
Plants glabrous throughout except for a few gland-tipped hairs on the petioles and leaf margins; leaves subhastate, subtruncate or cordate at the base, finely denticulate, the lobes narrowly oblanceolate or oblong-lanceolate, acute or acuminate, usually much longer than broad; bracts 2-3-pinnatisect, $3-4 \mathrm{~cm}$. long, the segments not closely interlaced; flowers $4-5 \mathrm{~cm}$. broad, light blue or pale pink; ripe fruit $2.5-3.5 \mathrm{~cm}$. in diameter, bright red.

The Maya name of Yucatan is recorded as "pochcac." The plant is reported there to have narcotic and sedative properties, producing deep and restful sleep.

Passiflora foetida var. gossypiifolia (Desv.) Masters, Trans. Linn. Soc. 27: 631. 1871. P. gossypiifolia Desv. in Hamilt. Prodr. Fl. West Ind. 48. 1825. Granadilla; granadilla de culebra; sandia de ratón; granadillita amarga.

Dry to wet thickets, sometimes on banks or in open fields, 2,000 meters or less; Petén; Alta Verapaz; Izabal; Zacapa; Jalapa; Jutiapa; Santa Rosa; Escuintla; Guatemala; Sacatepéquez; Chimaltenango; Quiché; Retalhuleu; Huehuetenango. Western Texas; Mexico; British Honduras to El Salvador and Costa Rica; West Indies; South America.

Plants villous or hirsutulous throughout, often viscid, the indument grayish or yellowish, the hairs mostly $1.5 \mathrm{~mm}$. long or shorter; leaf blades averaging about $5 \mathrm{~cm}$. long and broad, undulate or crenate-serrulate, the basal lobes usually semicircular in outline, sometimes abruptly narrowed to an obtuse apex; bracts $2-3 \mathrm{~cm}$. long, 2-3-pinnatisect, the ultimate segments not closely interlaced; ovary sparsely or densely hirsute, the hairs persistent in age; fruit $2-2.5 \mathrm{~cm}$. in diameter, yellow or greenish yellow, spotted with red.

"Pooch, pochil" (Yucatan, Maya); "pepe" (Oaxaca). This plant, like all forms of $P$. foetida, has a strong and disagreeable odor when crushed, the odor doubtless arising from the glands borne so profusely on most parts of the vine. In most varieties the plants are extremely viscid and unpleasant to handle. Normally they climb over bushes or small trees but when growing in the open they often spread widely over the ground.

Passiflora foetida var. hastata (Bertol.) Masters, Trans. Linn. Soc. 27: 631. 1871. P. hastata Bertol. Fl. Guat. 427. 1840. Dysosmia hastata M. Roem. Fam. Nat. Syn. 2: 149. 1846. Granadilla.

Moist or rather dry thickets, 300 meters or less; Alta Verapaz; Izabal; Escuintla (type from Escuintla, Velásquez); Retalhuleu. Southern Mexico; British Honduras.

Plants not or scarcely viscid, densely hirsute throughout with long yellowish hairs; leaves hastate, the pubescence chiefly of appressed or subappressed hairs, 
the middle lobes lanceolate or oblong-lanceolate, acute or acuminate, the lateral lobes rounded or acute; bracts $3-3.5 \mathrm{~cm}$. long after anthesis; ovary glabrous; fruit $2.5-3 \mathrm{~cm}$. in diameter; flowers greenish white or pale purplish green.

\section{Passiflora foetida var. hirsutissima Killip, Carnegie Inst.} Wash. Publ. 461: 326. 1936.

Moist or wet thickets, 300-1,500 meters; endemic; Alta Verapaz (type from Sepacuité, Mary W. Owen 9; collected also near Rubeltein and Cubilgüitz).

Plants densely hirsute or lanuginous-hirsute throughout, most of the hairs more than $2 \mathrm{~mm}$. long, stiff, yellowish; leaves subhastate or hastate, the middle lobes ovate or oblong-ovate, acute or acuminate; bracts $2 \mathrm{~cm}$. long at anthesis, 3-pinnatisect, the segments closely and densely interlaced, densely long-hirsute; flowers $2.5 \mathrm{~cm}$. broad, pale pink, the sepals and petals densely spotted with deep pink within; ovary glabrous.

Passiflora foetida var. lanuginosa Killip, Carnegie Inst. Wash. Publ. 461: 325. 1936.

Moist or wet thickets or sometimes in open fields or on sand dunes, 200 meters or less; Petén; San Marcos. Southern Mexico; British Honduras.

A small or rather large, herbaceous vine, the stems hirsute with spreading yellowish hairs $2 \mathrm{~mm}$. long or more; leaves hastate or subhastate, hirsutulous or hirsute above, lanuginous beneath, hirsute on the nerves and veins, the middle lobes oblong or oblong-ovate, acute or acuminate; bracts $1.5-5 \mathrm{~cm}$. long, the ultimate segments usually elongate, not closely interlaced; ovary glabrous; fruit 2-3 cm. in diameter, yellowish or reddish.

Passiflora foetida var. mayarum Killip, Carnegie Inst. Wash. Publ. 461: 327. 1936.

Wet to dry thickets, sometimes on gravel bars along streams, 400 meters or less; Retalhuleu; Huehuetenango. British Honduras (type collected along Belize-Sibun road, Belize District, $P$. $H$. Gentle 6).

Plants slender, the stems glabrous or with a few scattered long spreading hairs; leaves hastate or subhastate, hirtellous above with subappressed hairs, densely and softly pilosulous beneath, the middle lobe oblong to ovate, acute or acuminate, the lateral lobes broadly ovate or suborbicular, rounded or rarely subacute at the apex; bracts as much as $4 \mathrm{~cm}$. long, the segments not closely interlaced; sepals and petals cream-colored, or the flowers purple and white; ovary glabrous; fruit 2-2.5 $\mathrm{cm}$. in diameter, red.

Passiflora foetida var. nicaraguensis Killip, Carnegie Inst. Wash. Publ. 461: 328. 1936. P. hastata var. nicaraguensis Killip in Standl. Field Mus. Bot. 10: 293. 1933. 
Moist or wet thickets, 250 meters or less; Petén; Izabal; Santa Rosa; Escuintla; Suchitepéquez; Retalhuleu. Southern Mexico; British Honduras; Honduras; Nicaragua.

Plants glabrous throughout or nearly so; leaves hastate, ciliate, the lateral lobes usually elongate, rounded or subacute at the apex, the middle lobe usually ovate-elliptic, acute or obtuse; bracts $3-4 \mathrm{~cm}$. long in fruit, the segments not closely interlaced; flowers purplish white or greenish purple; fruit $2.5-3 \mathrm{~cm}$. in diameter, glabrous.

This variety and var. ciliata are much alike and scarcely worthy of separation.

Passiflora foetida var. subintegra Killip, Carnegie Inst. Wash. Publ. 461: 328. 1936.

Known only from the type, All Pines, British Honduras, W. A. Schipp 648.

Plants glabrous throughout, the stems very slender; leaves lanceolate or usually somewhat hastate, 4-6 cm. long, 1-2 cm. broad, acuminate, undulate, the basal lobes very short and rounded; bracts $2 \mathrm{~cm}$. long at anthesis, the ultimate segments not closely interlaced; flowers dark rose; fruit scarlet.

Among the Guatemalan names reported for Passiflora foetida, the variety uncertain, are "granadilla de culebra, pasión, tujo" (Petén). From other regions: "melón de ratón" (British Honduras); "granadilla colorada, sandía de culebra" (El Salvador); "tuuboc" (Yucatan, Maya); "jujito peludo" (Tabasco). The fruit in all forms of the species is edible but not very good.

Passiflora Hahnii (Fourn.) Masters in Mart. Fl. Bras. 13, pt. 1: 569. 1872. Disemma Hahnii Fourn. Rev. Hort. 41: t. 430. 1869. P. guatemalensis Wats. Proc. Amer. Acad. 22: 473. 1887 (type from Río Chocón, Izabal, S. Watson 81).

Wet forest or thickets, often or usually on limestone, 800 meters or less; Petén; Izabal. Southern Mexico; British Honduras to Costa Rica; Colombia.

A slender glabrous vine, herbaceous, the stems wiry, terete, angulate above, striate; stipules reniform, $1 \mathrm{~cm}$. long, setiferous-dentate; petioles $1.5-3 \mathrm{~cm}$. long, eglandular; leaf blades ovate-orbicular, 5-8 cm. long, 3.5-7 cm. broad, entire or usually shallowly and inconspicuously trilobate, obtuse or acute and mucronate at the apex, peltate a short distance above the base, 3-5-nerved, membranaceous; peduncles solitary, $7 \mathrm{~cm}$. long or shorter; bracts 2 , rounded-cordate, $2.5-3 \mathrm{~cm}$. long, 1.5-2 cm. broad, denticulate toward the base, the teeth terminated by short setae; flowers 4-6 cm. broad; sepals and petals similar, oblong, 2-3 cm. long, 7-9 mm. broad, obtuse, spreading, white or cream-colored; corona filaments biseriate, yellow, the outer as much as $15 \mathrm{~mm}$. long, spreading, dilated at the apex, the inner ones $5 \mathrm{~mm}$. long or less, clavate, erect; ovary glaucous, subglobose or ovoid, glabrous; 
fruit globose, 3-3.5 cm. in diameter; seeds ovate-oblong, slightly compressed, $5 \mathrm{~mm}$. long, $4 \mathrm{~mm}$. broad, reticulate.

\section{Passiflora Helleri Peyr. Linnaea 30: 54. 1859.}

Moist or wet, usually dense, mixed forest, 1,400 meters or less; Alta Verapaz; Baja Verapaz; Izabal; Suchitepéquez; Quezaltenango. Southern Mexico.

A small or rather large, herbaceous vine, the stems almost glabrous or finely pubescent; stipules linear-subulate, $3 \mathrm{~mm}$. long; petioles $2-3 \mathrm{~cm}$. long, eglandular; leaf blades ovate-oblong to orbicular in outline, $3.5-8 \mathrm{~cm}$. long, $3-7 \mathrm{~cm}$. broad, trilobate at the apex, the lobes usually very short, acute to almost truncate, mucronulate, the middle lobes usually longest, the blades rounded or subcuneate at the base, 3-nerved, reticulate-veined, ocellate beneath, thick-membranaceous, almost glabrous or minutely puberulent beneath on the nerves; peduncles $2-3.5 \mathrm{~cm}$. long, articulate just below the base of the flower; bracts setaceous, $1.5-2.5 \mathrm{~mm}$. long, deciduous; flowers $3-4 \mathrm{~cm}$. broad; sepals oblong-lanceolate, $13-15 \mathrm{~mm}$. long, obtuse, green outside, greenish white within; petals narrowly oblong, $1 \mathrm{~cm}$. long, $4 \mathrm{~mm}$. broad, white tinged with pink; corona filaments uniseriate, 5-7 mm. long, green and purple-dotted along the margin outside, purple within along the margin; ovary ovoid, minutely pilose; fruit globose, glabrate, $1.5 \mathrm{~cm}$. in diameter.

This has been reported from Guatemala as P. trisetosa DC., a Mexican species.

\section{Passiflora holosericea L. Sp. Pl. 958. 1753.}

Moist or dry thickets, 700 meters or less, mostly on the plains; Zacapa; Chiquimula; Santa Rosa; Escuintla; Retalhuleu. Mexico; Honduras; El Salvador; Cuba; northern South America.

A small or often large vine, herbaceous or somewhat woody, very densely and softly velutinous-pilose or tomentose throughout, the stems terete, the lowest ones often covered with thick corky bark; stipules filiform, $6 \mathrm{~mm}$. long; petioles 1-2.5 $\mathrm{cm}$. long, bearing near the middle 2 dark brown, sessile glands $2 \mathrm{~mm}$. in diameter; leaf blades 5-15 cm. long, 4-14 cm. broad, rather thick, shallowly trilobate, entire, cordate at the base, 3-nerved, reticulate-veined, densely velutinouspubescent above, tomentose beneath, the lobes rounded, mucronate, the middle ones much longer than the others; peduncles solitary or geminate in the leaf axils, 2-4-flowered or those of the lower axils rarely 1-flowered, the flowers pedicellate, the pedicels bearing 2-3 subulate bractlets $2 \mathrm{~mm}$. long; flowers $3-4 \mathrm{~cm}$. broad; sepals ovate-lanceolate, $13-15 \mathrm{~mm}$. long, obtuse, densely pubescent outside, glabrous and white within, sparsely spotted with red; petals oblanceolate or spatulate, 10-13 mm. long, $6 \mathrm{~mm}$. broad, white, streaked with brown and mottled with red; corona filaments biseriate, the outer ones lanceolate, $7 \mathrm{~mm}$. long, yellow at the apex, purple toward the base, the inner ones capillary, $4-5 \mathrm{~mm}$. long, clavate; ovary obovoid, densely pilose; fruit globose, $1.5 \mathrm{~cm}$. in diameter, glabrous or softly pubescent; seeds obovate-obcordate, $3 \mathrm{~mm}$. long, $2 \mathrm{~mm}$. broad, coarsely reticulate.

A common plant in the coastal thickets of the Pacific but scarce elsewhere in Guatemala. 
Passiflora ligularis Juss. Ann. Mus. Hist. Nat. 6: 113, t. 40. 1805. Granadilla; cranix (Quiché).

Moist or wet, usually dense, mixed forest or in thickets, 9002,500 meters; Alta Verapaz; Baja Verapaz; Jalapa; Sacatepéquez; Suchitepéquez; Huehuetenango; Quezaltenango; San Marcos; much cultivated in the mountain regions, at middle or rather high elevations. Central and southern Mexico; El Salvador; Honduras; Costa Rica; widely distributed in South America.

A large, coarse vine, glabrous throughout, the stems stout, terete; stipules ovate-lanceolate or oblong-lanceolate, $1-2.5 \mathrm{~cm}$. long, acute or acuminate, narrowed at the base, entire or serrulate; petioles $4-10 \mathrm{~cm}$. long, bearing 4-6 scattered, liguliform or filiform glands $3-10 \mathrm{~mm}$. long; leaf blades broadly ovate, 8-19 $\mathrm{cm}$. long, 6-14 cm. broad, abruptly acuminate, deeply cordate at the base, entire, membranaceous; peduncles solitary or geminate, $2-4 \mathrm{~cm}$. long; bracts $2-3.5 \mathrm{~cm}$. long, 1-1.5 cm. broad, connate one-fifth to one-third their length, the free portions ovate or ovate-lanceolate, acute, entire; flowers 6-9 $\mathrm{cm}$. broad; calyx tube shortcampanulate; sepals ovate-oblong, $2.5-3.5 \mathrm{~cm}$. long, acute, green outside, white within; petals oblong, about $3 \mathrm{~cm}$. long, $8-10 \mathrm{~mm}$. broad, white or pinkish white; corona filaments 5-7-seriate, the filaments of the two outer rows as long as the petals, radiate, terete, blue at the apex, banded with white and reddish purple below, the inner filaments barely $2 \mathrm{~mm}$. long; fruit ovoid or ellipsoid, $6-8 \mathrm{~cm}$. long and 4-5 cm. broad or slightly larger, the pericarp yellowish, purplish, or dark reddish, thick and tough, the pulp about the seeds white; seeds narrowly obcordate, $6 \mathrm{~mm}$. long, $4 \mathrm{~mm}$. broad, minutely tridentate at the apex, the sides irregularly reticulate.

This species is the granadilla of Central America, being the only species grown commonly there for its edible fruit. The term "granadilla" is derived, of course, from granada, the Spanish term for the pomegranate, that being doubtless the only Mediterranean fruit with which the early explorers could associate this strange new product of the Indies. The fruit of $P$. ligularis generally is considered superior in flavor to that of such species as $P$. maliformis and P. laurifolia, which are much grown in some other parts of tropical America. The vines are grown very commonly in the mountains of Guatemala as well as in other countries of Central America, and the fruits are produced in vast quantities and carried long distances for sale in regions where the plants are not cultivated. Granadillas are eaten raw. They are much liked by most persons because of their agreeable flavor, and they are easy to eat; the tough rind is opened and the pulp and seeds removed with a spoon. The seeds are crisp and crunchy, and often are chewed and eaten with the abundant pulp. Just where $P$. ligularis is native in Central America is rather uncertain, for many of the specimens are taken from cultivated plants and collectors seldom note on their labels whether the plants were found wild or in gardens. There can be no doubt, however, that the species 
is native in the mountains of Guatemala-or else it has become widely naturalized in places where it appears native. The juice of the fruit is often used for flavoring beverages and ices.

\section{Passiflora macrostemma Killip, Field Mus. Bot. 23: 217. 1947.}

Moist slopes and thickets (type from Guatemala, Steyermark 31519). Endemic; Chiquimula; Zacapa.

Herbaceous vine, glabrous throughout; stem subangular; stipules falcatesubulate, $4 \mathrm{~mm}$. long, subpersistent; petioles 1-1.5 cm. long, glandless; leaf blades membranous, sublustrous on both surfaces, rounded or subtruncate at the base, ocellate beneath, bilobed one-half to two-thirds their length, $1.5-4 \mathrm{~cm}$. long along the midnerve, 4-9 $\mathrm{cm}$. along the lateral nerves, $3-7 \mathrm{~cm}$. between the apices of the lobes, the lobes erect or very slightly divaricate, $1.2-3 \mathrm{~cm}$. broad, rounded, the sinus rounded or subtruncate; peduncles in pairs, 2-3 cm. long, divaricate; bracts setaceous, 2.5-3 mm. long, borne just below the base of the flower; flowers 3-4 cm. broad when expanded, the calyx tube broadly campanulate; sepals lanceolate, about $2 \mathrm{~cm}$. long, $1 \mathrm{~cm}$. broad at the base, obtuse, ecorniculate, greenish purple without, deep lavender within; petals oblong, about $1.5 \mathrm{~cm}$. long, 4-5 mm. broad, obtuse, membranous, deep lavender; corona 1-ranked, the filaments numerous, filiform, 6-7 mm. long, erect; operculum membranous, erect, 4-5 mm. high, very slightly plicate, purple, green at the base; nectar ring none; limen about $3 \mathrm{~mm}$. high, the base closely surrounding the gynophore, the margin spreading outward, entire; gynophore about $1 \mathrm{~cm}$. long, rather stout; ovary subglobose.

Passiflora membranacea Benth. Pl. Hartweg. 83. 1841 (based on material from Cuesta de Argueta, Sololá and Volcán de Agua, Sacatepéquez, Hartweg, without number). Cieca membranacea M. Roem. Fam. Nat. Syn. 2: 140. 1846. Granadilla; granadilla silvestre.

Dense, moist or wet, mixed forest, occasionally in oak forest, sometimes in exposed places in thickets, often on cliffs or in white sand, 1,350-3,000 meters, chiefly at the higher elevations; El Progreso; Sacatepéquez; Chimaltenango; Sololá; Suchitepéquez; Quezaltenango; San Marcos. Southern Mexico; Honduras; El Salvador; Costa Rica.

A small or often very large, slender, herbaceous vine, glabrous throughout; stipules cordate-reniform, 1-1.5 cm. long, 1.5-3 cm. broad, obscurely crenulate; petioles $2-4 \mathrm{~cm}$. long, eglandular; leaf blades orbicular or nearly so in outline, 5-10 cm. long and broad, obscurely and very shallowly trilobate at the apex, peltate a short distance above the base, 3-nerved, membranaceous, usually tinged with red or purple when young, glaucescent beneath; peduncles solitary, 9-15 cm. long; bracts 2-3, cordate-ovate or cordate-reniform, $3-5 \mathrm{~cm}$. long, 2-4 cm. broad, obtuse or rounded at the apex, red-purple, rose-colored, or reddish green, thin; flowers white or cream-colored; calyx tube broadly campanulate, $2 \mathrm{~cm}$. broad at the base; sepals oblong-lanceolate, $3.5-4 \mathrm{~cm}$. long, $1 \mathrm{~cm}$. broad, obtuse, erect; petals oblanceolate, $3.5-4 \mathrm{~cm}$. long; corona filaments biseriate, the outer ones 8-10 $\mathrm{mm}$. long, filiform, deep red, the inner ones capillary, barely $2 \mathrm{~mm}$. long, capitellate; 
gynophore about $4 \mathrm{~cm}$. long; ovary narrowly ellipsoid, trisulcate; fruit ovoid or ellipsoid, 4-8 cm. long, green or yellow, the flesh light green, bitter; seeds black, oblong-ovate, $4.5 \mathrm{~mm}$. long, $3 \mathrm{~mm}$. broad, deeply punctate.

This vine is abundant in many places in the mountains of the Occidente, often almost completely covering shrubs or good-sized trees, or forming festoons over cliffs. It is the handsomest and showiest of Guatemalan Passifloras, not because of the flowers but on account of the large and delicately colored bracts. The vines often creep closely along the trunks of cypress (Cupressus) trees, giving a strange effect of having been planted there.

Passiflora morifolia Masters in Mart. Fl. Bras. 13, pt. 1: 555. 1872. P. Heydei Killip, Journ. Wash. Acad. Sci. 12: 258.1922 (type from Casillas, Santa Rosa, Heyde \& Lux 3772). Granadilla de monte; granadilla de Castilla; granadilla.

Moist or rather dry thickets, sometimes on dry open grassy slopes, 1,300-2,100 meters; Jalapa; Santa Rosa; Guatemala; Huehuetenango; San Marcos. Mexico(?); Peru to Argentina.

A rather stout, herbaceous vine, the stems somewhat 4-angulate, hispidulous or glabrate; stipules semiovate, $6 \mathrm{~mm}$. long, long-acuminate, minutely hispidulous; petioles $6 \mathrm{~cm}$. long or less, hispidulous or glandular-pubescent, biglandular, the glands borne on the upper part of the petiole, thick-stipitate, $1.5 \mathrm{~mm}$. long; leaf blades membranaceous, 4-11 cm. long, 5-15 cm. broad, trilobate to below the middle, deeply cordate at the base, 3-nerved, repand-dentate or subentire, dark green above and hispidulous with minute uncinate hairs, paler and minutely pilosulous beneath, the lobes acute, the middle lobe ovate or ovate-lanceolate, usually narrowed below; peduncles solitary or geminate, 1-2 cm. long; bracts setaceous, $2.5-3 \mathrm{~mm}$. long, inserted about $1 \mathrm{~cm}$. below the base of the flower; flowers 2-3 cm. broad; sepals linear-oblong, 1-1.5 cm. long, obtuse, densely hispidulous to glabrate outside, green, glabrous and white within, mottled with red, the apex terminating in a horn $3.5 \mathrm{~mm}$. long; petals linear-lanceolate, 6-8 $\mathrm{mm}$. long, obtuse, white; corona filaments uniseriate, filiform, 5-6 mm. long, white banded with blue or violet; ovary subglobose, densely pubescent, glaucous; fruit globose, $2 \mathrm{~cm}$. in diameter, bluish black and glaucous, hispidulous; seeds very slightly compressed, obcordate-obovoid, $4 \mathrm{~mm}$. long, coarsely reticulate.

One collection that we refer here was named $P$. pilosa Ruiz \& Pavón by Killip, and another was indicated as a new species, near $P$. exsudans Zucc. There is no doubt that the species of this alliance have been divided too finely and that the characters depended upon for separating them, especially the position of the petiolar glands, are inconstant and unreliable.

Passiflora Nelsonii Mast. \& Rose, Contr. U. S. Nat. Herb. 5: 142, t. 17. 1897. 
Moist or wet, mixed forest, 1,000-1,800 meters; Alta Verapaz; Huehuetenango. Southern Mexico, the type from Tumbala, Chiapas.

A large, herbaceous vine, glabrous throughout or nearly so, the stems terete; stipules oblanceolate, 10-12 $\mathrm{mm}$. long, acuminate, narrowed at the base, deciduous; petioles 2-3 $\mathrm{cm}$. long, bearing 2 pairs of sessile saucer-shaped glands near the apex; leaf blades broadly ovate, $9-17 \mathrm{~cm}$. long, $8-11 \mathrm{~cm}$. broad, acuminate, rounded or cordate at the base, entire, penninerved, thick-nembranaceous; peduncles solitary, $3 \mathrm{~cm}$. long or less; bracts broadly ovate, $5-6 \mathrm{~cm}$. long, $3.5-4.5 \mathrm{~cm}$. broad, acuminate, free almost to the base; flowers 5-7 cm. broad; sepals oblong-lanceolate, $3 \mathrm{~cm}$. long, $1 \mathrm{~cm}$. broad, corniculate just below the apex; petals equaling and slightly narrower than the sepals; corona filaments several-seriate, the outermost filaments subulate, 1-1.5 $\mathrm{cm}$. long, the inner ones 1-2 $\mathrm{mm}$. long; gynophore stout, 7-9 $\mathrm{mm}$. long; ovary narrowly obovoid; fruit subglobose.

Passiflora normalis L., a synonym of $P$. perfoliata L., a Jamaican species, was reported by Bertoloni as collected in Guatemala by Velásquez, with the local name "camacarnata." It is quite uncertain what the plant so listed may have been, and the vernacular name has not been noted as in use in Guatemala, although a similar name is used in El Salvador for P. pulchella.

Passiflora obovata Killip, Carnegie Inst. Wash. Publ. 461: 308, t. 1. 1936.

Known only from the type, Petén, Camp 35 on the British Honduras boundary, 850 meters, W. A. Schipp 713 .

A large glabrous vine as much as 18 meters long, the stem $5 \mathrm{~cm}$. in diameter, subangulate; stipules soon deciduous; petioles $2 \mathrm{~cm}$. long, biglandular just above the middle, the glands oblong, scar-like, $1 \mathrm{~mm}$. long; leaf blades obovate or oblongobovate, 9-12 cm. long, 5-6.5 cm. broad, rather abruptly acuminate, slightly narrowed at the base, entire, obscurely 5-plinerved, chartaceous, lustrous; peduncles geminate, $2.5-3 \mathrm{~cm}$. long, articulate above the middle; bracts minute, triangularovate, acute, closely appressed to the peduncle and inserted near its base; flowers $4 \mathrm{~cm}$. broad, greenish white; calyx patelliform, the sepals oblong, $1.5 \mathrm{~cm}$. long, $8 \mathrm{~mm}$. broad, obtuse; petals linear-oblong, $13 \mathrm{~mm}$. long, $4 \mathrm{~mm}$. broad; corona filaments biseriate, the outer ones ligulate, about equaling the petals, the inner capillary, $2 \mathrm{~mm}$. long, minutely capitellate; ovary globose; ovules apparently reticulate.

Passiflora Oerstedii Masters in Mart. Fl. Bras. 13, pt. 1: 562. 1872.

Moist or wet thickets, 1,200-1,400 meters; Suchitepéquez; Quezaltenango. Southern Mexico; Costa Rica; Colombia and Venezuela.

A small or large, herbaceous vine, the stems slender, terete or nearly so; stipules semiovate, $1-4 \mathrm{~cm}$. long, $5-15 \mathrm{~mm}$. broad, acuminate and usually longcuspidate, rounded at the base; petioles $1-4 \mathrm{~cm}$. long, bearing 4-6 or rarely 2 scattered or geminate, stipitate glands; leaf blades ovate-lanceolate to narrowly 
oblong-lanceolate, 6-13 cm. long, 3-9 cm. broad, obtuse to long-acuminate, rounded or usually subcordate at the base, subpeltate, 5-7-nerved, entire or nearly so, membranaceous, glabrous above, glaucescent beneath and usually thinly pilose or villosulous with somewhat matted hairs; peduncles $2-4 \mathrm{~cm}$. long, glabrous; bracts ovate-lanceolate, $1-1.5 \mathrm{~cm}$. long, 5-8 $\mathrm{mm}$. broad, acute, rounded or cordate at the base, serrulate, reticulate-veined, inserted $5-10 \mathrm{~mm}$. below the base of the flower, deciduous; flowers 4-6 cm. broad; calyx tube campanulate, 7-8 mm. long, the sepals ovate-lanceolate, 2-3 cm. long, 5-12 mm. broad, cucullate at the apex, carinate, the keel terminating in a short awn, white within; petals linear, $1-1.5 \mathrm{~cm}$. long, 3-5 mm. broad, obtuse, white or pinkish; corolla filaments several-seriate, purple, those of the 2 outer series filiform, 1.5-2 cm. long, erect, the innermost $1.5-3 \mathrm{~mm}$. long; ovary ovoid, glabrous, glaucous; fruit ovoid, 4-6 cm. long, 2-3 cm. broad; seeds narrowly obovate, 4-5 $\mathrm{mm}$. long, 2-3 $\mathrm{mm}$. broad, shallowly tridentate, coarsely reticulate.

Much more common in Guatemala than the typical form of the species is the following variety:

Passiflora Oerstedii var. choconiana (Wats.) Killip, Carnegie Inst. Wash. Publ. 461: 321. 1936. P. choconiana Wats. Proc. Amer. Acad. 22: 474. 1887 (type from Río Chocón, Izabal, S. Watson 212).

Moist or wet, mixed forest or thickets, 1,500 meters or less; Petén; Alta Verapaz; Baja Verapaz; Izabal; Santa Rosa; San Marcos. Southern Mexico; British Honduras; Atlantic coast of Honduras; Costa Rica.

A small or large, herbaceous vine; differing from the typical form of the species only in having the leaves deeply trilobate.

Called "cacapache" and "granada" in Veracruz. Schipp reports the flowers as blue.

Passiflora ornithoura Masters in Donn.-Sm. Bot. Gaz. 16: 8. 1891. P. dichthyophylla Masters, loc. cit. (type from Dueñas, Sacatepéquez, J. D. Smith 2136). Granadilla de montaña; calzoncillo.

Wet to dry thickets or forest, 2,000 meters or less; Zacapa; Chiquimula; Jalapa; Santa Rosa; Escuintla; Guatemala; Sacatepéquez; Chimaltenango; Sololá; Huehuetenango. El Salvador; Costa Rica.

Plants glabrous, the stems compressed, striate; stipules setaceous, $3 \mathrm{~mm}$. long, deciduous; petioles $1.5-2.5 \mathrm{~cm}$. long, eglandular; leaves bilobate usually to below the middle, often almost to the base, cuneate to rounded at the base, 3-nerved, membranaceous, entire, deep green above and often with a broad silvery stripe along the costa, paler beneath or glaucescent, the lobes linear to ovate, 3-10 cm. long, 5-20 mm. broad, acute or obtuse, mucronulate, usually ascending, sometimes spreading; peduncles geminate, $1-2 \mathrm{~cm}$. long; bracts setaceous, $1.5 \mathrm{~mm}$. long; flowers $1.5 \mathrm{~cm}$. broad; sepals oblong, 7-8 mm. long, obtuse; petals linear, $5 \mathrm{~mm}$. long, hyaline, white; corona filaments uniseriate, linear-clavate, barely 
$2 \mathrm{~mm}$. long; fruit globose, 6-8 $\mathrm{mm}$. in diameter, purple-black; seeds strongly compressed, broadly ovate, $2 \mathrm{~mm}$. long, $2 \mathrm{~mm}$. broad, transversely sulcate with about 6 conspicuously rugulose ridges.

This has been reported from Guatemala as $P$. mexicana Juss.

\section{Passiflora Palmeri Rose, Contr. U. S. Nat. Herb. 1: 131, t. 14. 1892.}

Plants usually low and densely branched shrubs, or more elongate and scandent, very viscid, the branches densely pilose; stipules semiannular, deeply cleft into filiform gland-tipped divisions; petioles $1-1.5 \mathrm{~cm}$. long, pilose, bearing numerous coarse gland-tipped hairs; leaf blades 1-3 cm. long, 2-4 cm. broad, trilobate, cordate at the base, 3-5-nerved, serrulate, densely glandular-ciliate, densely brownhirsute-tomentose, the lobes orbicular, rounded at the apex; peduncles $4-5 \mathrm{~cm}$. long; bracts $2-4 \mathrm{~cm}$. long, pilose, deeply 2-pinnatisect into capillary gland-tipped segments; flowers 5-7 cm. broad; sepals linear, $3.5 \mathrm{~cm}$. long, 3-nerved, pilose, white within, slender-awned dorsally just below the apex; petals linear, $2-3 \mathrm{~cm}$. long, white, 1-nerved; corona filaments several-seriate, those of the two outer series erect, capillary, $2.5 \mathrm{~mm}$. long; gynophore slender, $2 \mathrm{~cm}$. long; fruit globose, $2.5-3 \mathrm{~cm}$. in diameter, densely pilose; seeds oblong or narrowly cuneate, $6 \mathrm{~mm}$. long, $2 \mathrm{~mm}$. broad, tridentate at the apex, reticulate.

The typical form of the species is known only from Baja California, Mexico. The species is represented in Guatemala by the following variety:

Passiflora Palmeri var. sublanceolata Killip, Carnegie Inst. Wash. Publ. 461: 322. 1936.

Petén (between Uaxactún and San Clemente, $H$. H. Bartlett 12788). Mexico (Yucatan peninsula).

Leaf blades lanceolate in general outline, $3-5 \mathrm{~cm}$. long, $2-3.5 \mathrm{~cm}$. broad, the basal lobes much reduced; bracts $2-2.5 \mathrm{~cm}$. long, $8-10 \mathrm{~mm}$. broad; flowers said to be "bright scarlet" or rose-red.

Passiflora Pavonis Masters, Journ. Bot. 21: 35. 1883.

Moist or wet thickets or forests near streams or in sandy oak forest, 2,400-2,600 meters; Huehuetenango; Quezaltenango; San Marcos. Central and southern Mexico.

A large, herbaceous vine, the stems angulate, glabrous or sparsely pubescent; stipules narrowly falcate, $3 \mathrm{~mm}$. long, acuminate, deciduous; petioles $5-15 \mathrm{~mm}$. long, densely pubescent, eglandular; leaf blades $1-5.5 \mathrm{~cm}$. long, 2-7.5 cm. broad, broad and shallowly trilobate at the apex, rounded at the base, 3-5-nerved, entire, green and glabrous above, paler beneath and thinly or densely pilose, the lobes subequal, short and broad, rounded or truncate at the apex, mucronate; peduncles geminate, 1-2.5 cm. long, puberulent; bracts none; flowers $1.5-2 \mathrm{~cm}$. broad, yellowish green or greenish white; calyx tube setulose, ventricose at the base; sepals linear-lanceolate, 10-12 mm. long, $2 \mathrm{~mm}$. broad, acuminate, obscurely 3-nerved, 
minutely puberulent; petals 3-4 mm. long, acute; corona filaments biseriate, capillary, the outer ones one-third to one-half as long as the petals, reflexed; ovary setulose; fruit globose, 6-8 mm. in diameter, glabrate; seeds broadly ovate, compressed, $2.5 \mathrm{~mm}$. long, $2 \mathrm{~mm}$. broad, transversely rugose, with 6 rounded, conspicuously rugulose ridges.

Passiflora platyloba Killip, Journ. Wash. Acad. Sci. 12: 260. 1922. Granadilla.

Moist or dry, often rocky thickets, on plains or hillsides, 150 1,400 meters; Chiquimula; Jutiapa; Santa Rosa; Retalhuleu. El Salvador; Nicaragua; Costa Rica.

A small, herbaceous vine, glabrous except on the bracts, the stems stout, terete, striate; stipules coriaceous, linear, 10-12 mm. long, 3-nerved, remotely serrulate, deciduous; petioles $6-7 \mathrm{~cm}$. long, bearing above the base 2 sessile flattened glands $2 \mathrm{~mm}$. broad; leaf blades 10-14 cm. long, $12-18 \mathrm{~cm}$. broad, trilobate to the middle, deeply cordate at the base, finely serrulate, biglandular in the sinuses, 3-5-nerved, membranaceous, the middle lobes broadly ovate, abruptly acuminate, $4-8 \mathrm{~cm}$. broad, the lateral lobes almost equaling the middle one; peduncles solitary, 6-7 cm. long; bracts ovate, entire, 5-7 cm. long, 3-5 cm. broad, membranaceous, inserted $1 \mathrm{~cm}$. below the apex of the peduncle, completely enveloping the flower, united for about $2 \mathrm{~cm}$., acute or obtuse, densely puberulent on both surfaces; flowers purple, 4-5 cm. broad; calyx tube campanulate, $1 \mathrm{~cm}$. long; sepals oblong-lanceolate, 18$20 \mathrm{~mm}$. long, $8 \mathrm{~mm}$. broad, obtuse, strongly carinate, the keel terminating in an awn 5-6 mm. long; petals linear-lanceolate, 15-17 mm. long, $5 \mathrm{~mm}$. broad, thin, obtuse; corona several-seriate, the outermost filaments filiform, $7 \mathrm{~mm}$. long, those of the second series stout, liguliform, $15 \mathrm{~mm}$. long, white banded with purple; gynophore glabrous; ovary ellipsoid, glabrous; fruit $3-3.5 \mathrm{~cm}$. long, with a hard pericarp.

Called "granadilla ácida" and "granadilla montés" in El Salvador, where the very acid fruit is used for preparing iced beverages.

\section{Passiflora porphyretica Masters in Donn.-Sm. Bot. Gaz. 20:} $538, t .36 .1895$.

Known in Guatemala only from the type (Jutiapa, 420 meters, Heyde \& Lux 6334). Southern Mexico.

Stems terete, densely pubescent or hirsute; stipules cordate, $8-10 \mathrm{~mm}$. long, reddish or violet-purple, densely ciliate; petioles $1-2.5 \mathrm{~cm}$. long, densely hirsute, eglandular; leaf blades orbicular in outline, 5-10 cm. long and broad or smaller, broad at the apex and shallowly 2-3-lobate, rounded or subcordate at the base, 3 -nerved, reticulate-veined, strigillose and somewhat scabrous above, densely paletomentose beneath, the lobes short and broad, rounded to subacute at the apex, mucronate; peduncles geminate on the main stems or usually on axillary leafy branches, the leaves often absent and the inflorescence thus appearing racemose; bracts similar to the stipules, broadly cordate, $10 \mathrm{~mm}$. long, $8 \mathrm{~mm}$. broad, obtuse, reddish or violet-purple, glabrate outside, pilosulous within; flowers $3 \mathrm{~cm}$. broad; sepals linear-oblong, $1.5 \mathrm{~cm}$. long, $3 \mathrm{~mm}$. broad, very densely pilose outside, gla- 
brate within; petals linear-oblong, $8 \mathrm{~mm}$. long, obtuse, pink; corona filaments filiform, spotted with purple, biseriate, the outer ones $6-8 \mathrm{~mm}$. long, the inner $2 \mathrm{~mm}$. long; ovary globose, densely white-pilose; fruit globose, $1 \mathrm{~cm}$. in diameter; seeds transversely sulcate, with 6-8 rugulose ridges.

\section{Passiflora prolata Masters, Bot. Jahrb. 8:219.1887. Granadilla.}

Moist or wet thickets or forest, 200-2,000 meters; endemic; Petén; Chiquimula; Jalapa; Jutiapa; Santa Rosa; Suchitepéquez; Sololá (type from Sultán, F. C. Lehmann 1630); Quezaltenango; San Marcos.

A large or small, herbaceous vine, the stems obtusely angulate, glabrous or puberulent; stipules linear-setaceous, 4-15 mm. long, decidous; petioles 1-2 cm. long, 2-4-glandular near the middle, the glands subsessile; leaf blades trilobate to the middle, 5.5-12 cm. long, 6-13 cm. broad, rounded or subcordate at the base, serrulate, membranaceous, glabrous or finely puberulent beneath, the lobes lanceolate or oblong-lanceolate, caudate-acuminate; peduncles $3-4 \mathrm{~cm}$. long; bracts free to the base, ovate-lanceolate, $4.5-5 \mathrm{~cm}$. long, $1.5-2 \mathrm{~cm}$. broad, entire, membranaceous, green, glabrous or puberulent; flowers 5-7 cm. broad; calyx tube campanulate; sepals oblong, 2-2.5 cm. long, 8-10 mm. broad, long-aristate dorsally just below the apex, white within; petals oblong-spatulate, slightly shorter than the sepals, obtuse, white; corona filaments several-seriate, filiform, purple, those of the 2 outer series $2 \mathrm{~cm}$. long, the innermost half as long; ovary ellipsoid, glabrous.

Passiflora pulchella HBK. Nov. Gen. \& Sp. 2: 134. 1817. P. pulchella var. bifidata Masters, Bot. Jahrb. 8:220. 1887 (type from Chiquimula, Chiquimula, F. C. Lehmann 1708).

Moist or dry, often rocky thickets, 900 meters or less; Chiquimula; Jutiapa; Santa Rosa; Escuintla; Retalhuleu. Southern Mexico; El Salvador to Panama; Colombia and Venezuela.

Usually a small vine, herbaceous or often woody below, glabrous throughout or nearly so; stipules linear, subfalcate, 5-7 mm. long; petioles $1.2 \mathrm{~cm}$. long, eglandular; leaf blades $2-6 \mathrm{~cm}$. long along the costa, 5-10 cm. broad between the tips of the lobes, bilobate one-fourth to one-half their length or sometimes truncate, truncate to subcuneate at the base, 3-nerved, chartaceous, prominently reticulateveined, ocellate beneath, the lobes divaricate to suberect, truncate or rounded at the apex; peduncles solitary, 5-8 cm. long; bracts suborbicular or ovate, 1-1.5 cm. long, 8-10 mm. broad, subacute or obtuse, abruptly narrowed at the base, membranaceous, inserted $2 \mathrm{~mm}$. below the base of the flower, purplish red; flowers 4.5-5.5 $\mathrm{cm}$. broad, deep blue; sepals oblong, obtuse, $2 \mathrm{~cm}$. long, 7-9 mm. broad; petals ovate-lanceolate or oblong-lanceolate, $13-15 \mathrm{~mm}$. long, $4 \mathrm{~mm}$. broad; corona filaments several-seriate, filiform, the outermost equaling the petals, those of the inner series 4-5 mm. long; ovary subglobose, glabrous; fruit globose, 1-1.5 cm. in diameter; seeds obovate, 2-3 $\mathrm{mm}$. long, $1 \mathrm{~mm}$. broad, transversely sulcate, with about 6 rugulose ridges.

Known in El Salvador by the names "calzoncillo" and "camacarlata." 
Passiflora quadrangularis L. Syst. ed. 10. 1248. 1759. P. macrocarpa Masters, Gard. Chron. 1869: 1012. 1869. Granadilla real.

Planted occasionally in Guatemala, from the capital down to the coasts, but infrequent; native of tropical America, but the native habitat uncertain; not found wild in Guatemala or elsewhere in Central America, unless as a rare escape from cultivation. Figure 16.

A large, coarse, glabrous, herbaceous vine, the stems stout, 4-angulate and conspicuously winged along the angles; stipules ovate or ovate-lanceolate, $2-3.5 \mathrm{~cm}$. long, acute, narrowed at the base, entire or slightly serrulate; petioles stout, 2$5 \mathrm{~cm}$. long, 6-glandular, the glands geminate, almost sessile; leaves broadly ovate or oblong-ovate, $10-20 \mathrm{~cm}$. long, $8-15 \mathrm{~cm}$. broad, entire, abruptly acuminate, rounded to shallowly cordate at the base, penninerved; peduncles $1.5-3 \mathrm{~cm}$. long, triangulate; bracts cordate-ovate, $3-5.5 \mathrm{~cm}$. long, $1.5-4 \mathrm{~cm}$. broad, acute or subacute, entire or serrulate toward the base, thin-membranaceous; flowers as much as $12 \mathrm{~cm}$. broad; calyx tube campanulate; sepals ovate or oblong-ovate, $3-4 \mathrm{~cm}$. long, cucullate at the apex, corniculate, greenish or reddish green outside, white, violet, or pinkish within; petals oblong-ovate or oblong-lanceolate, $3-4.5 \mathrm{~cm}$. long, 1-2 $\mathrm{cm}$. broad, obtuse, white tinged with pink; corolla 5 -seriate, the outer filaments as much as $6 \mathrm{~cm}$. long, banded with reddish purple and white at the base, blue at the middle, mottled with pinkish blue in the upper half; fruit oblong-ovoid, $20-30 \mathrm{~cm}$. long and $12-15 \mathrm{~cm}$. broad or even larger, terete or longitudinally somewhat trisulcate; seeds broadly obcordate or suborbicular, 7-10 mm. long, strongly compressed, reticulate at the center on each side, radiately striate at the margins.

This species is easily recognized by the sharply angled and broadly winged stems, and by the very large, green fruits, which are surprisingly light in weight considering their great size. The pulp is acid and in some regions is much used for flavoring beverages and ices. It is not often, if ever, eaten alone. In some places in the Central American lowlands this vine is cultivated commonly for its fruits but it is scarce in Guatemala, and we have not observed the fruits in any of the local markets.

Passiflora reflexiflora Cav., a synonym of which is Tacsonia laevis Benth. (Pl. Hartweg. 118. 1843) has been reported from Guatemala on the basis of Hartweg 662, which was reported to have come from Guatemala. It is now believed that there was an error in the locality data of this number of Hartweg's collections, and that the material really came from Ecuador.

Passiflora Rovirosae Killip, Journ. Wash. Acad. Sci. 12: 259. 1922. Xicozotz (Maya); ala de murciélago.

At 200 meters or lower; Petén (Uaxactún, H. H. Bartlett 12691). Southern Mexico; British Honduras. 


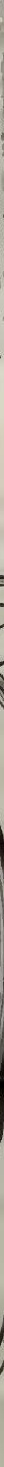

FIG. 16. Passiflora quadrangularis. Habit, flower and fruit; reduced. 
Stems 5-angulate, striate, pilosulous when young, glabrate in age; stipules falcate-subulate, 8-10 mm. long, soon deciduous; petioles $1.5-2 \mathrm{~cm}$. long, densely pubescent, eglandular; leaf blades truncate-ovate in outline, 8-15 cm. long, 6-9 cm. broad, shallowly bilobate or subtruncate at the apex, deeply cordate at the base, slightly narrowed above, membranaceous, puberulent or glabrate above, pale beneath and grayish-villosulous, the lobes very short, suberect, acute, mucronate; peduncles 1-1.5 cm. long, 1-flowered, geminate or on short, axillary, sometimes leafy, puberulent branches 1-2 cm. long, the inflorescence thus appearing racemose; bracts none; flowers 3-4 cm. broad, yellowish green; sepals oblong, 13-15 mm. long, $4 \mathrm{~mm}$. broad, obtuse; petals oblong, obtuse, $8-10 \mathrm{~mm}$. long, $3 \mathrm{~mm}$. broad; corona filaments biseriate, the outer ones filiform, $1 \mathrm{~cm}$. long, the inner capillary, barely $4 \mathrm{~mm}$. long; ovary narrowly ovoid, sharply 6-angulate, puberulent; fruit fusiform or ellipsoid, $3-4 \mathrm{~cm}$. long, $1.5-2 \mathrm{~cm}$. broad, sharply 6-angulate; seeds obovate, $4 \mathrm{~mm}$. long, $3 \mathrm{~mm}$. broad, black, lustrous, transversely sulcate, with
$5-6$ smooth ridges.

\section{Passiflora serratifolia L. Sp. Pl. 955. 1753. Caranilicho (Quecchí).}

Moist or wet thickets or forest, 500 meters or less; Petén; Alta Verapaz; Izabal. Mexico; British Honduras along the Atlantic coast to Costa Rica.

Usually a large vine, the stems terete, striate, hirtellous; stipules linear-subulate, $7 \mathrm{~mm}$. long, serrulate toward the apex; petioles $5-12 \mathrm{~cm}$. long, densely hirtellous, bearing 6 clavate glands about $1 \mathrm{~mm}$. long; leaf blades ovate or ovateoblong, 8-12 cm. long, 4-7 cm. broad, acuminate, rounded or subcordate at the base, serrulate, membranaceous or chartaceous, glabrate above, short-hirtellous beneath; peduncles solitary, 5-7 cm. long; bracts oblong-lanceolate, 2-3 cm. long, 8-10 mm. broad, acute, green, finely pubescent; flowers $4-6 \mathrm{~cm}$. broad, the calyx tube campanulate; sepals lanceolate, $2.5-3 \mathrm{~cm}$. long, 5-8 mm. broad, carinate, the keel terminating in an awn $2 \mathrm{~mm}$. long, purplish; petals oblong-lanceolate, 1.5-2 cm. long, 4-6 mm. broad, obtuse, purplish; corona filaments several-seriate, the outermost filiform, $2.5-3.5 \mathrm{~cm}$. long, radiate, purple at the base, white toward the apex, those of the inner series 1-2 mm. long, banded with purple and white; ovary ellipsoid, glabrous; fruit ovoid or subglobose, 5-9 cm. long, 3.5-5 cm. broad, lemon-yellow, glabrous, edible; seeds compressed, cuneate, $6-7 \mathrm{~mm}$. long, 4-5 mm. broad, tridentate at the apex, reticulate.

Called "granadilla" in Honduras and doubtless also in Guatemala; "jujito amarillo" (Campeche).

Passiflora sexflora Juss. Ann. Mus. Hist. Nat. 6: 110, t. 37, f. 2. 1805. Ala de murciélago.

Moist or wet, mixed forest or thickets, sometimes in oak or pine forest, 300-2,500 meters; Alta Verapaz; Baja Verapaz; El Progreso; Jalapa; Santa Rosa; Escuintla; Guatemala; Sacatepéquez; Chimaltenango; Sololá; Suchitepéquez; Quiché; Huehuetenango; Quezalte- 
nango; San Marcos. Southern Florida; southern Mexico; Honduras; Costa Rica; Panama; West Indies; Colombia.

A large or small, herbaceous or suffrutescent vine, the stems subangulate, densely pilose; stipules linear-subulate, about $5 \mathrm{~mm}$. long; petioles $2.5-3 \mathrm{~cm}$. long, pilose, eglandular; leaf blades membranaceous, 3-8 $\mathrm{cm}$. long along the costa, 5$11 \mathrm{~cm}$. broad, trilobate, rounded or subcordate at the base, entire, hirsutulous and often setulose above, softly pilose or tomentose beneath, the middle lobe usually shorter than the lateral ones, these acute to rounded at the apex; peduncles geminate, 2-10-flowered; bracts and bractlets linear-lanceolate, $3-5 \mathrm{~mm}$. long, irregularly few-cleft or subentire; flowers $1.5-3 \mathrm{~cm}$. broad; sepals lanceolate, $8-15 \mathrm{~mm}$. long, 2-4 mm. broad, acute, densely hirsute outside, glabrous within, white; petals linear, $8-10 \mathrm{~mm}$. long, obtuse; corona filaments biseriate, the outer ones as long as the petals, white at the apex, purple below, those of the inner surface half as long, purple throughout, capitate; ovary globose, densely brown-pubescent; fruit globose or depressed-globose, 6-10 mm. in diameter, densely pubescent; seeds obovate, slightly compressed, black, transversely 6-7-sulcate, the ridges rugulose.

This is one of the commonest species of Passiflora in Guatemala.

\section{Passiflora sicyoides Schlecht. \& Cham. Linnaea 5: 88. 1830.}

Moist or wet thickets, sometimes in oak forest, 1,750 meters or lower; Santa Rosa (Laguna de los Pinos); Quiché; Huehuetenango. Central and southern Mexico.

A slender, herbaceous vine, the stems slender, pilose or glabrate; stipules semiovate, cuspidate, $5-7 \mathrm{~mm}$. long; petals $2-6 \mathrm{~cm}$. long, pilose, bearing at the middle 2 subopposite stipitate glands $1.5 \mathrm{~mm}$. long; leaf blades thin-membranaceous, 5-12 cm. long, 4-15 cm. broad, trilobate, entire or nearly so, cordate at the base, 3 -nerved, minutely pilose on both surfaces or almost glabrous, glaucescent beneath, the lobes deltoid, acuminate to obtuse; peduncles solitary or geminate, half as long as the petioles; bracts setaceous, $3 \mathrm{~mm}$. long; flowers $3-4 \mathrm{~cm}$. broad, the calyx tube pilose; sepals oblong-lanceolate, $12-20 \mathrm{~mm}$. long, 6-10 $\mathrm{mm}$. broad, acute, sparsely pilose; petals ovate-lanceolate, $5-12 \mathrm{~mm}$. long, greenish white; corona filaments uniseriate, 7-8 $\mathrm{mm}$. long, linear, white, with 4-5 transverse purple bands; ovary ovoid, stipitate, glabrous; fruit obovoid, tapering to a stipe $2 \mathrm{~cm}$. long; seeds obcordate, abruptly acute at the base, $5 \mathrm{~mm}$. long, $4 \mathrm{~mm}$. broad, coarsely reticulate.

Passiflora suberosa L. Sp. Pl. 958. 1753. Granadilla; chilocayotillo; granadilla roja.

In moist or dry, often rocky, mixed or oak forest or in thickets, 1,000-2,000 meters; Petén; Chiquimula; Jalapa; Guatemala; Sacatepéquez; Chimaltenango; Huehuetenango. Southern Florida; western Texas; Mexico; British Honduras to El Salvador and Panama; West Indies; widely distributed in South America.

A slender vine, usually small and more or less woody, glabrous to densely pubescent, the larger stems with corky bark; stipules linear-subulate, $6-8 \mathrm{~mm}$. long; petioles $0.5-4 \mathrm{~cm}$. long, biglandular, the glands small, stipitate, inserted above the 
middle of the petiole; leaf blades very variable in shape, entire to deeply trilobate, rounded or sometimes peltate at the base, membranaceous or subcoriaceous, sometimes ocellate beneath, the lobes linear to broadly ovate, acute or obtuse, erect or divergent; flowers solitary or geminate in the leaf axils or sometimes in leafy axillary racemes, 1-3 cm. broad; bracts minute, setaceous, soon deciduous; sepals ovate-lanceolate, subobtuse, greenish yellow; petals none; corona filaments biseriate, filiform, the outer ones recurved, white, yellow at the apex, purple below; ovary subglobose or ovoid, glabrous; fruit globose or ovoid, dark purple or black, glaucous when young, 6-15 mm. in diameter; seeds flattened, abruptly acuminate, tapering to the base, 3-4 $\mathrm{mm}$. long, $2 \mathrm{~mm}$. broad, coarsely reticulate.

Called "calzoncillo" in El Salvador; "zac-cansel-ac," "cansel-ac" (Yucatan, Maya).

Passiflora subpeltata Ortega, Nov. Rar. Pl. Hort. Matr. 6: 78. 1798. P. alba Link \& Otto, Icon. Pl. Rar. 65, $t$. 33. 1828.

Moist or dry thickets or hedges, or sometimes in forest, 1,2002,000 meters; Chiquimula; Jalapa; Guatemala; Quiché; Huehuetenango. Central and southern Mexico; Panama; Greater Antilles; Colombia and Venezuela.

Usually a large vine, herbaceous or suffrutescent below, glabrous throughout or nearly so, the stems terete, striate; stipules semioblong, $1-4 \mathrm{~cm}$. long, $0.5-2 \mathrm{~cm}$. broad, mucronate, entire, or glandular-crenate at the base; petioles $4-6 \mathrm{~cm}$. long, bearing 2-4 minute liguliform glands $1 \mathrm{~mm}$. long or shorter; leaf blades 4-6 $\mathrm{cm}$. long, 5-12 $\mathrm{cm}$. broad, trilobate to the middle or deeper, subcordate and of ten subpeltate at the base, glabrous or nearly so, the lobes oblong or oval, $4 \mathrm{~cm}$. broad or narrower, rounded or obtuse at the apex, subentire, glandular-serrulate in the sinuses; peduncles $4-6 \mathrm{~cm}$. long; bracts ovate-oblong, 1-1.5 cm. long, $1 \mathrm{~cm}$. broad, acute or obtuse, cordate and slightly serrulate at the base, inserted near the base of the flower; flowers 4-5 cm. broad; sepals oblong, 5-10 mm. broad, obtuse, green outside, white within, carinate, the keel terminating in a green foliaceous horn $1 \mathrm{~cm}$. long; petals linear-oblong, about equaling the sepals; corona filaments 5seriate, white, the outer ones as much as $2 \mathrm{~cm}$. long, filiform, spreading, the inner ones only $2-4 \mathrm{~mm}$. long; ovary ovoid, glaucous; fruit ovoid or subglobose, $2.5-4 \mathrm{~cm}$. in diameter; seeds obovate, compressed, $5 \mathrm{~mm}$. long, $3 \mathrm{~mm}$. broad, the beak slightly curved, finely reticulate.

Passiflora trinifolia Masters, Bot. Jahrb. 8: 217. 1887. Hoja de murciélago; granadilla; calzoncillo.

Mostly in moist or wet, mixed, often dense, mountain forest, or in thickets, 1,200-2,700 meters; endemic; Baja Verapaz (type from Santa Rosa, F. C. Lehmann 1314); Zacapa; Jalapa; Guatemala; Quezaltenango; San Marcos.

Usually a rather small vine, the stems slender, terete, minutely puberulent; stipules ovate-lanceolate to orbicular, 5-8 $\mathrm{mm}$. long, 4-6 $\mathrm{mm}$. broad, mucronate; petioles mostly $1 \mathrm{~cm}$. long or shorter, bearing 2 flattened glands at or slightly above 
the middle, or the glands sometimes absent; leaf blades bright green, rather thick and firm, 1.5-11 cm. long and $2.5-15 \mathrm{~cm}$. broad, trilobate to about the middle, more or less cordate and 5-nerved at the base, reticulate-veined, ocellate, glabrous or minutely puberulent, the lobes triangular-ovate, subequal or the lateral ones somewhat larger, usually acute or acuminate, the lateral lobes generally widely spreading; peduncles geminate, equaling or slightly shorter than the petioles, articulate above the middle; flowers 1-2 cm. broad, yellowish green; sepals deltoidlanceolate, $7 \mathrm{~mm}$. long, $6 \mathrm{~mm}$. broad, subcoriaceous; petals none; corona filaments uniseriate, filiform, dilated toward the apex, $4 \mathrm{~mm}$. long, erect; ovary subglobose, glabrous or minutely puberulent; fruit black, lustrous, globose, $1.5 \mathrm{~cm}$. in diameter; seeds obovoid, $4 \mathrm{~mm}$. long, very coarsely reticulate.

This plant is very common in the forests of the Occidente. It is particularly attractive because of the neat leaves of a hand some shade of green, in their form somewhat suggestive of English ivy (Hedera).

Passiflora Urbaniana Killip, Journ. Wash. Acad. Sci. 17: 426. 1927.

British Honduras (Churchyard Pine Ridge, Sibun River; Honey Camp). Described from plants grown at Santiago de las Vegas, Cuba, the seeds said to have come from British Honduras.

Stems terete, ferruginous-villosulous or tomentose; stipules minute, semiannular, barely $0.5 \mathrm{~mm}$. long; petioles $5-10 \mathrm{~mm}$. long, eglandular, densely ferruginoustomentose; leaf blades oblong or lance-oblong, 4.5-9 cm. long, 2-4 cm. broad, obtuse or rounded at the apex, subcordate at the base, entire or remotely undulatecrenulate, coriaceous or subcoriaceous, minutely hispidulous above, densely and softly ferruginous-tomentose beneath; peduncles 5-8 cm. long, pilosulous; bracts 2-3.5 cm. long, 1-1.5 cm. broad, viscous, deeply 2-pinnatisect; flowers $5 \mathrm{~cm}$. broad, the calyx tube short-campanulate; sepals oblong, $2 \mathrm{~cm}$. long, $6 \mathrm{~mm}$. broad, obtuse, greenish and hirsutulous outside, 3-nerved, the middle nerve carinate toward the apex and terminating in a short horn; petals linear, slightly shorter than the sepals, lavender; corona filaments 5-seriate, those of the two outer series filiform, $13 \mathrm{~mm}$. long, violet at the base, radiate, those of the inner series almost capillary, $2 \mathrm{~mm}$. long, erect; ovary subglobose, densely villous-tomentose; fruit globose, $3.5 \mathrm{~cm}$. in diameter, villous; seeds oblong-cuneate, $4 \mathrm{~mm}$. long, $3 \mathrm{~mm}$. broad, shallowly tridentate, finely reticulate.

\section{CARICACEAE. Papaya Family}

Trees, shrubs, or large coarse herbs, with milky sap; leaves usually very large, long-petiolate, palmately lobate or palmately 3-few-foliolate; flowers small or rather large, usually white or cream-colored, unisexual or rarely perfect; calyx small and short; staminate corolla salverform, the tube slender, the 5 short lobes valvate or convolute; stamens 10 (or sometimes only 5), inserted in the throat of the corolla, the filaments short; anthers adnate to the filaments, 2-celled; pistillate flowers with 5 distinct petals and no staminodia; ovary compound, 1-celled or imperfectly 5-celled, free, sessile, the stigmas 5, sessile; ovules numerous, in 2 or more 
series on the 5 placentae; fruit a large, fleshy berry; seeds numerous, compressed or subglobose, the testa roughened; endosperm carnose, the embryo axile.

There are four, perhaps five, rather poorly differentiated genera in the family. One genus is tropical African, the others are all tropical American. There is one other genus in Mexico and another in southern Central America. Jacaratia is in cultivation in Guatemala.

\section{GARICA L. Papaya}

Trees, shrubs, or large herbs, the trunk usually simple, sometimes branched, unarmed; leaves long-petiolate, simple and deeply lobate; inflorescences axillary, cymose-racemose, the bracts usually very small, the flowers dioecious; staminate corolla with an elongate slender tube, the lobes in bud contorted or valvate; stamens inserted in 2 series in the throat of the corolla, free, the outer ones with elongate filaments, the inner ones short, the connective often produced into a ligule beyond the anther cells; style short, the $\mathbf{5}$ stigmas linear or variously cleft; fruit small or often very large, the pulp filling it, or a large cavity often present; seeds numerous, covered with a succulent membrane, rugose-tuberculate.

Species perhaps 30 or more, in tropical America, mostly in South America. Two others are described from Panama.

Leaves usually digitately compound, with 3-7 leaflets; sometimes branched trees.

C. mexicana.

Leaves simple, lobate; plants usually with simple stems, herbaceous or somewhat woody.

Stigmas palmately cleft or divided; cultivated or wild plants, the fruits mostly large and edible, sometimes small and scarcely edible......... Papaya.

Stigmas pinnatifid; wild plants, the fruits mostly $3.5-5 \mathrm{~cm}$. long, not edible.

C. pennata.

Carica mexicana (A. DC.) L. Wms. Fieldiana, Bot. 29: 368. 1961. Jacaratia mexicana A. DC. Prodr. 15, pt. 1:420. 1864. Carica dolichaula Donn.-Sm. Bot. Gaz. 23: 247. 1897. Leucopremna mexicana Standl. Contr. U. S. Nat. Herb. 23:850.1924. Pileus mexicanus Johnston, Contr. Gray Herb. n.s. 70: 79. 1924. Jacaratia dolichaula Woodson, Ann. Mo. Bot. Gard. 37: 404. 1950; 45: 23, f. 1958. Chaya silvestre (perhaps an erroneous name).

Moist or dry lowland forest or scrub, 800 meters or less; Petén; Alta Verapaz; Huehuetenango; Izabal. Mexico; British Honduras through Central America to Panama.

A tree 5-12 m. tall or more, sometimes blooming when a shrub $3 \mathrm{~m}$. tall, the trunk slender or thick, the bark pale brown, almost smooth, glabrous throughout; leaves long-petiolate, the leaflets 3-7, oblong or obovate-oblong, sometimes obovate-elliptic, mostly $9-18 \mathrm{~cm}$. long, cuspidate-acuminate to almost obtuse, acute 
at the base, petiolulate or sessile, entire or lobate, glaucescent beneath; peduncles axillary, few-many-flowered, the flowers fragrant, greenish to cream-colored; calyx 1-2 mm. long, the sepals oblong-ovate or subtriangular, obtuse; corolla of the pistillate flowers 3-7 cm. long, the segments linear or linear-lanceolate; corolla of the staminate flowers 5-6 cm. long, tubular below, the free lobes 1-2 cm. long and oblong-elliptic; fruit obovoid, 4-15 $\mathrm{cm}$. long or perhaps even larger, sometimes 5 -angled and produced at the base into cone-like protuberances or wings; seeds many and large, often filling the single-celled or falsely 5-celled cavity.

The Maya name for this plant in Yucatan is reported to be "cunche" or "cumche." In other regions of Mexico it is called "bonete orejona" or "papaya orejona." In Mexico it is said that the fruits are sometimes eaten raw, especially in salads, or that they are made into sweetmeats of various kinds. When maize is scarce the Mayas of Yucatan are said to pulverize the pith of the plant and mix it with maize in making tortillas, although this seems unlikely.

Carica Papaya L. Sp. Pl. 1036. 1753. Papaya (fruit); papayo (plant).

Cultivated everywhere at 1,200 meters or lower, and sometimes at even higher elevations; often found wild in waste ground, second growth, and generally in moist or wet thickets, especially along the lowlands of the Atlantic watershed. Native of tropical America, but the original home unknown; now grown generally in almost all tropical regions. Figure 17.

Plants with a rather thick, usually simple, columnar trunk at maturity, the trunk bearing conspicuous petiolar scars, commonly 3-6 meters high, leafy at the top; leaves very large, on long petioles, mostly $30-60 \mathrm{~cm}$. wide but sometimes larger, usually palmately 7-lobate, more or less glau cous beneath, the lobes pinnatelobate, obtuse or acute; staminate flowers creamy white, in usually lax, pedunculate panicles 10-30 cm. long; staminate calyx $1-1.5 \mathrm{~mm}$. long, the corolla $2.5-3 \mathrm{~cm}$. long, the lobes lanceolate or elliptic-lanceolate, equaling or somewhat shorter than the tube; pistillate sepals $5-10 \mathrm{~mm}$. long, the corolla longer than that of the staminate flowers, the petals distinct, lanceolate, contorted; fruit very variable in shape and size, that of wild plants small and globose-obovoid, that of cultivated plants often very large and obovoid to oblong, yellow or orange at maturity, more or less streaked with green, with a somewhat milky juice, the flesh yellow or orange, very juicy and sweet.

The Maya names of Yucatan are "put" and "chichput" (the wild form). The term "papaya" is of Antillean origin, and is used for the fruit in most regions, except in Cuba, where it has come to have an obscene meaning, and the papaya there is called "fruta bomba." The Carib name is said to have been originally "ababaya." The papaya is one of the best of tropical fruits, and many people believe that it has few superiors anywhere. It is one for which it is not 


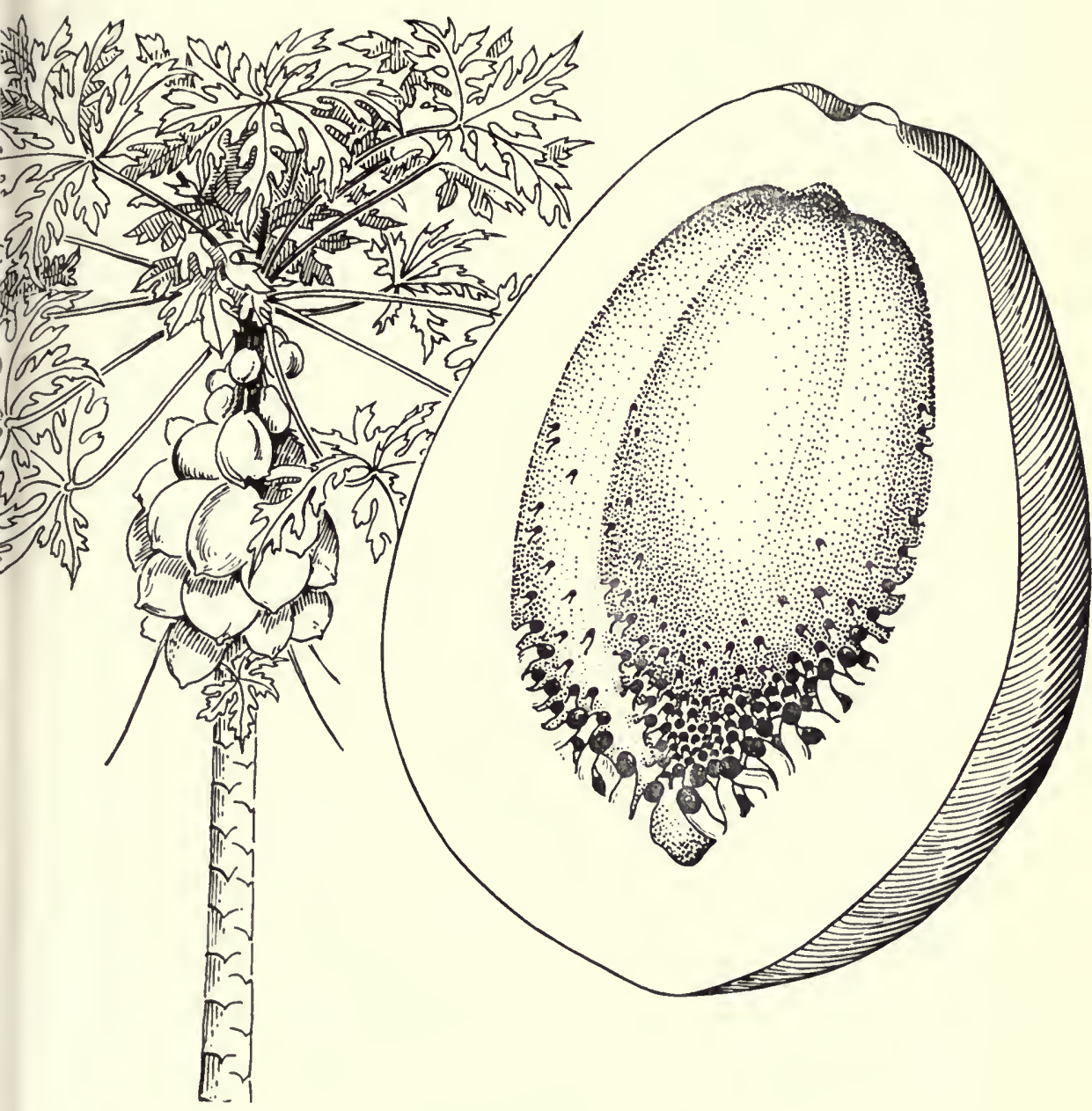

FIG. 17. Carica Papaya. Habit of plant, fruit; both much reduced. 
necessary to cultivate a taste; most northern people like it upon first trial and become very fond of it if they live long in the tropics. Almost all papayas are good when thoroughly ripe, and when stewed they also are excellent. The fruits vary greatly in shape and size, some being extremely large, especially those of Panama. There are numerous varieties in Guatemala, but in selecting them for the table little attention seems to be paid to the variations. While found everywhere in Guatemala at 1,200 meters or lower, and little planted above that limit, the fruits may be found on sale in all markets, for they are carried up from the lowlands in trucks or on the backs of cargadores, to the highland markets. Many of the fruits seen in the markets are scored with longitudinal knife cuts. It is claimed that if this is not done, the fruit is bitter; but quantities of unscored fruits sold in the markets and bought readily by the people seem just as sweet as those thus treated! The plants are essentially herbaceous. They are grown from seeds, and begin to bear when only about 2 meters high, continuing until they reach a height of about 6 meters. When so high, the heavy fruits are likely to cause the plants to fall to the ground, especially in case of a strong wind. In protected places in the Pacific lowlands extremely tall stems sometimes are seen, perhaps 9 meters high, but these plants seldom have fruits, and their terminal tuft of leaves is small. The trunks for the most part are simple, but it is not unusual to see a plant with a few thick branches at the top.

The larger papayas are sometimes as much as $50 \mathrm{~cm}$. long, with a weight of 20 pounds, but such a size is unusual. In appearance and flavor the flesh is much like that of a cantaloupe. The immature green fruits are cooked and eaten in some regions, but this is unusual in Central America, even though they "make better apple pie than apples do." A sirup made from the fruit is used in Central America as a remedy for coughs. The dried and powdered seeds as well as the milky sap are administered internally to kill intestinal parasites, and the milk is said to be applied to kill niguas (tropical chiggers).

It has long been known that the milk that exudes from all parts of the plant contains a substance called papain, similar in properties to animal pepsin. Tough meat wrapped in papaya leaves and left overnight is said to become tender, or some leaves may be boiled with the meat. This fact is widely published and reported, but it seems to be better known abroad than in Central America. If such use is made there of the plant, it is not common, and it is not be- 
cause the average meat of the region does not need such treatment! In recent years the papaya has become known to some extent in the United States. In favorable seasons it grows and produces well in southern Florida, and the fruits reach northern markets in small quantities.

Carica pennata Heilborn, Svensk. Bot. Tidskr. 30: 222, f. 4. 1936. Papayo de monte; papayo de montaña.

Moist or dry, rather open forest, thickets, and open clearings, often in sandy soil near streams on the plains, Pacific plains and bocacosta, 1,300 meters or less; Santa Rosa; Escuintla; Sacatepéquez; Suchitepéquez (described from plants grown in Sweden, the seeds collected at Tiquisate by N. Johansson in 1929); Retalhuleu; Quezaltenango; San Marcos. Probably also in El Salvador.

Plants herbaceous and usually 2 meters high or less, apparently annual, the stems slender; leaves scattered along the stems or at maturity mostly near the top of the stem, very large or small, long-petiolate, mostly 5-lobate, deeply cordate at the base, the middle lobe pinnatifid with acute to long-attenuate segments, the other lobes 3-fid or 2-fid, glaucous beneath; staminate inflorescences short or elongate and many-flowered, the calyx $1.5 \mathrm{~mm}$. long; corolla white, fading to yellowish, 3-3.5 cm. long, the lobes usually much shorter than the tube; pistillate inflorescences few-flowered, the flowers $2.5 \mathrm{~cm}$. long, the sepals minute; petals lanceolate or linear, $5 \mathrm{~mm}$. broad, acuminate; style $1 \mathrm{~mm}$. long, the 5 stigmas $8 \mathrm{~mm}$. long, pinnatifid with 5-7 lobes; fruit globose-obovoid, usually $3-5 \mathrm{~cm}$. long or of ten somewhat larger, yellow at maturity; seeds $3 \mathrm{~mm}$. long or slightly larger, very numerous.

It is assumed that this species is the common wild papaya of the Pacific plains and foothills. It grows there abundantly, forming extensive stands in open places, and often growing profusely in the more open forest. Most of the plants appear to last only a single season, dying if the soil becomes very dry. The fruits are small, orange-yellow within, and of poor flavor. They are not eaten. There is not available satisfactory material for testing the value of the stigma character on which Heilborn separated this species from C. Papaya. Tropical plants grown in northern hothouses often behave queerly, and the stigma characters should be investigated in the field before too much importance is attached to them, in spite of the fact that the author of the species established a separate section for it.

Jacaratia dodecaphylla (Vell.) A. DC., a tree native in Brazil, is in cultivation at Finca Panamá, Suchitepéquez. It is a good-sized 
tree with very prickly trunk and branches, the long-petiolate leaves palmately compound, with 7 or more, entire, narrow leaflets, glaucous beneath.

\section{LOASACEAE}

Reference: I. Urban \& E. Gilg, Monographia Loasacearum, Nova Act. Leop. Carol. Acad. 86: 1-380. 1900.

Herbs or rarely shrubs, erect or scandent, dichotomously branched, of ten covered with stinging hairs; hairs of the leaves usually rough and of ten glochidiate or anchor-shaped; leaves opposite or alternate, entire, lobate, pinnatifid, or 2-3 times pinnatifid; stipules none; flowers small or large, regular, perfect; inflorescence of solitary flowers, racemose or cymose, the peduncles of ten opposite the leaves, the pedicels bibracteolate; corolla usually white or yellow; calyx tube adnate to the ovary, the calyx lobes $4-5$, imbricate or contorted, herbaceous or chartaceous, persistent; petals $4-5$, inserted in the throat of the calyx, sessile or unguiculate, flat or cucullate, induplicate-valvate; petaloid scales alternate with the petals, cucullate, sometimes with dorsal appendages; stamens 4-12 or numerous, inserted with the petals, the filaments filiform, often collected in fascicles opposite the petals; anthers oblong or didymous, introrsely and longitudinally dehiscent, the filaments filiform; staminodia present between the stamens and petals or absent, sometimes petaloid; ovary inferior, rarely half superior, 1-celled or rarely 2-3celled, confluent with the calyx tube, often hispid at the free apex; style filiform or stiff, subulate, entire, or 2-3-fid, the lobes linear; stigma punctiform or obtuse; ovules solitary or numerous, affixed at the apex of the cell or on parietal placentae, pendulous, anatropous; capsule generally 1-celled, of ten costate, the costae straight or spirally twisted, 3-5-valvate at the apex or longitudinally $3-10$-valvate, the valves alternate with the placentae, the seeds 1-many, usually small, oblong or angulate; testa membranaceous or cellulose, of ten laxly reticulate; endosperm none or carnose, rarely corneous; embryo straight, linear, oblong, or cylindric; cotyledons plano-convex and foliaceous or hemispheric, the radicle short or elongate.

About 14 genera, all except one confined to America. One other genus, Klaprothia, is known from Costa Rica and Panama, two others from Mexico.

Ovary 1-ovulate; plants scandent; leaves palmate-nerved, deeply cordate at the base; plants covered with stinging hairs.................. Gronovia.

Ovary with few-many ovules; plants not scandent.

Plants covered with stinging hairs; leaves pinnately parted...........Loasa.

Plants without stinging hairs; leaves merely dentate or shallowly lobate.

Leaves all opposite; flowers minute, the petals $2 \mathrm{~mm}$. long or less; capsule spirally twisted....................... Sclerothrix.

Leaves all or mostly alternate; flowers much larger; capsule not spirally twisted.

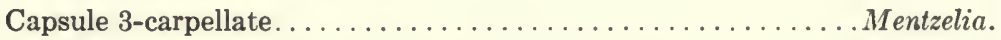

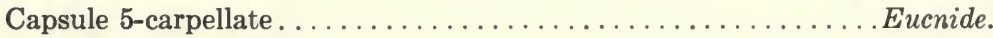




\section{EUCNIDE Zuccarini}

Annuals or sometimes more enduring, with brittle stems, the pubescence mostly of long and soft hairs, but these often barbellate at the apex and more or less irritant; lower leaves opposite, the upper ones alternate, usually long-petiolate; flowers 5-parted, solitary or in cymes, of ten very large, yellow or white; calyx tube subglobose to campanulate, the sepals imbricate; petals imbricate, united at the base; stamens numerous, in 2-5 series, united at the base, united with the petals and falling with them; staminodia none; style filiform; ovary inferior, with $\mathbf{5}$ or rarely 4 placentae, the ovules very numerous, horizontal; capsule obovoid or ellipsoid, dehiscent by 5 apical valves; stamens numerous, small, cylindric or elongate; endosperm present, the embryo straight.

About 10 species, ranging from southwestern United States to Guatemala.

Flowers about $2.5 \mathrm{~cm}$. long. . . . . . . . . . . . . . . bartonioides. Flowers about $7.5 \mathrm{~cm}$. long. . . . . . . . . . . . . . . . . . .

Eucnide bartonioides Zucc. Linnaea 18: 509. 1844.

Known in Guatemala only from Guastatoya, El Progreso, 300 meters, W. A. Kellerman 8062. Southern Mexico.

Plants probably annual, simple or branched, $40 \mathrm{~cm}$. high or less, densely pilose throughout with slender spreading whitish hairs, many of these barbate at the apex, the stems pale; leaves mostly on long slender petioles, rounded-cordate, thin and soft, mostly $2.5-6.5 \mathrm{~cm}$. long and almost or quite as broad, rounded or obtuse at the apex, deeply cordate at the base, shallowly lobate and sinuate-dentate, palmately nerved; peduncles axillary, 1-flowered, short at first but in age often much elongate, sometimes longer than the leaves; calyx densely long-pilose with spreading hairs, about $12 \mathrm{~mm}$. long, the lobes linear-lanceolate, longer than the tube; corolla yellow, about $2.5 \mathrm{~cm}$. long, the petals rounded at the apex, erect, glabrous or nearly so; stamens slightly or much exceeding the petals; capsule about $1 \mathrm{~cm}$. long.

The hairs, especially on the calyx, are often much thickened at the base.

Eucnide guatemalensis Standl. \& Steyerm. Field Mus. Bot. 23: 178. 1944.

Known only from the type, Huehuetenango, Cerro Chiquihui, above Carrizal, about 2,000 meters, Steyermark 50818.

A coarse branched herb, the branches thick, densely viscid-hispid; leaves on stout petioles $2.5-5.5 \mathrm{~cm}$. long, rounded in outline or ovate-rounded, 5-9 cm. long, 4.5-8.5 cm. broad, deeply and narrowly cordate at the base, very shallowly 5-9lobate, the lobes low and rounded, undulate or undulate-dentate, densely hispid on both surfaces; flowers numerous, the peduncles stout, 3-6 cm. long, densely viscid-hispid; hypanthium obconic or broadly turbinate, $9 \mathrm{~mm}$. long, 10-12 $\mathrm{mm}$. broad at the apex, densely hispid; sepals oblong-linear or narrowly lanceolate, 3-3.5 cm. long, 5-7 mm. broad, long-acuminate, densely viscid-hispid; petals about 
$5.5 \mathrm{~cm}$. long, and almost $2 \mathrm{~cm}$. broad, rounded at the apex, whitish green, very sparsely pilose outside with long, soft, white hairs or almost wholly glabrous; stamens very numerous, longer than the petals, about $7 \mathrm{~cm}$. long, the anthers $1.5 \mathrm{~mm}$. long; capsule $1.5 \mathrm{~cm}$. long.

\section{GRONOVIA L.}

Scandent herbs, pilose and provided with stinging hairs, the hairs of the stems uncinate at the apex; leaves alternate, long-petiolate, broadly cordate, 5 -lobate; flowers small, pedicellate, subcorymbose, the inflorescences opposite the leaves, few-many-flowered, the pedicels bearing small linear bractlets; calyx tube short, oblong, subangulate; sepals 5, united below; petals 5, yellowish green, inserted in the throat of the calyx, shorter than the sepals and narrower, linear-spatulate; stamens 5, inserted with the petals, the filaments filiform, puberulent, the anthers oblong; staminodia none; ovary inferior, 1-celled, the style inserted on an epigynous disc, filiform, the stigma capitellate; ovule solitary, pendulous from the apex of the cell; fruit small, crowned by the persistent calyx, subglobose, coriaceous, costate, indehiscent; seed with membranaceous-striate testa; endosperm none; cotyledons carnose, the margins lobulate, induplicate.

The genus is wholly American. One or two other species are known in Mexico.

Gronovia scandens L. Sp. Pl. 202. 1753. Güisquilillo (fide Aguilar).

Moist thickets or waste ground, 1,500 meters or less; Zacapa; Santa Rosa; Guatemala; Suchitepéquez; Huehuetenango. Southern Mexico; El Salvador and Honduras to Panama; southward to Ecuador.

Usually a small herbaceous vine with rather succulent stems, the stems bearing numerous long uncinate hairs mixed with shorter ones, sparsely branched; leaves thin, on petioles $3-6 \mathrm{~cm}$. long, the blades $3-8 \mathrm{~cm}$. long, deeply 5-lobate, deeply cordate at the base, the terminal lobe subulate-acuminate, the lobes all sublobate or coarsely dentate, sparsely or densely pilose on both surfaces, part of the hairs simple, part of them glochidiate at the apex; inflorescences pedunculate, 10-18-flowered; calyx 4-7 mm. long, yellowish green, the adnate basal portion 3-4 mm. long, the lobes oblong, acute; stamens $2-3 \mathrm{~mm}$. long, the petals scarcely longer; fruit obovoid or short-cylindric, 2.5-4 $\mathrm{mm}$. long.

Known in El Salvador as "pan caliente," "picapica," "chichicaste" and "Juan caliente"; "lalmuch" (Yucatan, Maya); "pan caliente" and "no me tientes" in Honduras; "pringamoza" or "pringamosca" in Nicaragua. The hairs of the plant sting severely and painfully. As remarked by Bentham and Hooker, the general appearance of this weedy plant is suggestive of many Cucurbitaceae, which the Guatemalan common name also suggests. 


\section{LOASA Jussieu}

Herbs, usually erect, hispid and setose, the hairs often stinging; leaves alternate or opposite, entire, lobate, or decompound; flowers large or small, axillary, solitary, racemose, or subpaniculate, mostly white or yellow; calyx tube turbinate to ovoid, clavate, or cylindric, the 5 lobes equal; petals 5 , cucullate, spreading or suberect, often connivent, alternating with 5 scales, these 2-3-setose dorsally and often appendaged at the base; stamens very numerous, the filaments filiform, collected in fascicles opposite the petals, the anthers didymous or oblong; staminodia 10 , filiform; ovary 1-celled, the style subulate, the stigma obtuse, acute, or shortly 3-fid; ovules numerous, affixed to 3-5 parietal placentae; capsule terete or costate, crowned by the persistent calyx, 3-valvate at the apex, many-seeded; seeds small or large, oblong or angulate, the testa usually cellulose and spongious; endosperm carnose, the embryo terete or compressed, the cotyledons plano-convex, rarely foliaceous.

Probably 100 species, all in tropical America and mostly South American. Two other species, with large, showy, yellow flowers, are found in Costa Rica and Panama.

Loasa triphylla Juss. Ann. Mus. Paris 5: 27, t. 5, f. 2. 1804.

A plant of wide distribution in western South America, represented in southern Mexico and Central America by the following variety:

Loasa triphylla var. rudis (Benth.) Urban \& Gilg, Nova Act. Leop. Carol. Acad. 86: 239. 1900. L. rudis Benth. Pl. Hartweg. 75. 1839 (type from Santa María, probably in Quezaltenango, Hartweg). Chichicaste.

Moist or wet thickets or forest, often along streams, sometimes on white sand slopes, 300-2,800 meters; Alta Verapaz; Retalhuleu; Quezaltenango; San Marcos. Southern Mexico; Costa Rica; Panama.

A rather weak, usually erect or sprawling herb, a meter high or less, pubescent everywhere with long hairs glochidiate at the apex and with long, fulvous, simple setae; leaves long-petiolate, the blades often $15 \mathrm{~cm}$. long or more, the lower ones with 2-4 pairs of petiolulate leaflets, these oval or oval-oblong, serrate, the upper leaves simple, short-petiolate; flowers rather few, large, in secund racemes, longpedicellate, about $2 \mathrm{~cm}$. broad; petals white, $1 \mathrm{~cm}$. long, caducous; capsule erect, $13-16 \mathrm{~mm}$. long, $1 \mathrm{~cm}$. broad above, turbinate-clavate, echinate with long, fulvous setae; seeds blackish, obovate, $1 \mathrm{~mm}$. long.

The plant is all too plentiful in many parts of the mountains or plains of western Guatemala, growing in abundance where it is kept permanently wet by the spray of water. The plant stings badly, leaving a persistent itching sensation. It is able to sting, like a nettle, through the cloth of ordinary trousers. 


\section{MENTZELIA L.}

Reference: Josephine Darlington, A monograph of the genus Mentzelia, Ann. Mo. Bot. Gard. 21: 103-226. 1934.

Annual or perennial herbs, rarely shrubs or small trees, usually erect, covered with various kinds of rigid, barbate, but not stinging hairs, the stems usually whitish or yellowish in age; leaves mostly alternate, lobate, dentate, or pinnatifid; inflorescence terminal, cymose, the flowers sometimes solitary, small or large, white or yellow; calyx tube cylindric to ovoid or turbinate, the limb 5-lobate, the lobes imbricate, deciduous or persistent; petals 5-10, imbricate, free or united and narrowed or contracted at the base, apiculate; stamens 10-many, inserted with the petals but free from them; filaments distinct or in clusters opposite the petals, filiform or linear, or the 10 outer ones broadened, sometimes petaliform, in 1-5 series; anthers introrse, laterally dehiscent; style elongate, filiform, trifid at the apex; ovary 1-celled, 2-many-ovulate, the placentae usually 3 ; capsule short, cylindric, oblong or turbinate, more or less distinctly costate at maturity, 3-7-valvate at the apex; seeds fiat or angulate, sometimes winged; endosperm copious or scant, the embryo erect or curved, the radicle conic or subterete.

Species about 60, all American. Only one is known from Central America.

\section{Mentzelia aspera L. Sp. Pl. 516. 1753. Pegapega.}

Moist or dry thickets, often in rocky places, $200-1,500$ meters; Zacapa; Jutiapa; Baja Verapaz; Guatemala; Quiché; Huehuetenango. Arizona and Mexico; British Honduras; Honduras; Nicaragua; Panama; West Indies southward to Brazil and Bolivia.

Plants annual, often much branched from the base or throughout, erect or ascending, a meter high or usually lower, the stems generally yellowish, very brittle, covered with short, glochidiate hairs intermixed with antrorse, spine-like ones; leaves alternate, lanceolate or ovate-lanceolate, 3-10 cm. long, slender-petiolate, acute or short-acuminate, serrate or dentate and of ten hastately trilobate, roughpubescent on both surfaces with chiefly glochidiate hairs; flowers sessile, axillary; calyx tube terete, attenuate to the base, $6-11 \mathrm{~mm}$. long, 2-3.5 mm. broad; calyx lobes lanceolate or linear-lanceolate, long-acuminate, 3-4 $\mathrm{mm}$. long or in age longer; petals obovate to obovate-orbicular, acute, 4-8 mm. long; stamens 20-30, the outer ones dilated and petaloid; capsule cylindric, $1.5-2.5 \mathrm{~cm}$. long, 3-5 mm. thick, inconspicuously striate, 3 -valvate at the apex; seeds 6-9, grayish yellow, irregularly tuberculate, undulate-striate, not winged.

Called "pegarropa" in Yucatan, and the Maya names are reported as "tzayuntzay" and "tsootscab." An unattractive plant and unpleasant to handle, although it does not sting. The rough leaves adhere tenaciously to clothing.

\section{SCLEROTHRIX Presl}

Annual or longer-lived, slender, weak herbs. Leaves opposite, petiolate, usually membranaceous, simple; inflorescence racemose, few-flowered, arising in the 
axils of leaves; calyx tube narrow, costate, the costae spirally twisted; calyx lobes 4 , triangular; petals 4 , sessile, obovate, apiculate; stamens 4-12, 1-3 of them opposite the petals; anthers small, oblong; ovary inferior, 1-celled; style subulate; capsule clavate, hispid-hirsute, few-many-seeded.

A small genus of one or perhaps two species ranging from Mexico through Central America well into South America.

Sclerothrix fasciculata Presl, Symb. Bot. 2: 3, t. 53. 1833. Ancyrostemma micranthum Poepp. \& Endl. Nov. Gen. \& Sp. 3: 65, t. 272. 1845. Pegapega.

In old fields or more often in sand or gravel along streams, occasionally in the forest, from 300-1,600 meters; San Marcos; Retalhuleu; Quezaltenango; Chimaltenango; Escuintla; Suchitepéquez. Mexico through Central America south to Peru and Bolivia.

Small, herbaceous plants with succulent stems to $50 \mathrm{~cm}$. tall; the stem sparsely to densely pubescent with retrorse hairs, somewhat branched or nearly simple; leaves lanceolate to broadly elliptic or ovate, acute or acuminate, serrate, appressed hirsute pubescent on both surfaces, $2-10 \mathrm{~cm}$. long and $0.7-4 \mathrm{~cm}$. broad; petioles slender, mostly about $1 \mathrm{~cm}$. long; inflorescences few-flowered, axillary racemes, pubescent; calyx clavate, costate and spirally twisted, densely short, stiff hirsute pubescent; calyx lobes short, triangular or nearly so, acute, about $1 \mathrm{~mm}$. long; petals about $1 \mathrm{~mm}$. long, sessile.

\section{BEGONIACEAE. Begonia Family}

\section{By Lyman B. Smith and Bernice G. Schubert}

References: A. DC. in DC. Prodr. 15, pt. 1: 266. 1864. Irmscher in Engler \& Prantl, Pflanzenfam. ed. 2. 21:548-588. 1925. C. Chevalier, Les Bégonias, 1938.

Annual or perennial herbs, shrubs or rarely small trees; stem elongate and succulent or woody or sometimes reduced to a tuberous rhizome, sometimes climbing; leaves usually alternate or rarely subverticillate, entire, serrate, lobed or digitately parted, usually asymmetric, sometimes peltate; stipules 2, free, persistent or deciduous; peduncles axillary; inflorescence mostly cymose, sometimes 1-flowered or racemose, cymes regular or strongly one-sided; flowers unisexual; tepals free or connate; stamens indefinite, inserted on the receptacle, filaments free or united; styles usually 3, free or connate, usually bifid; ovary inferior in the American species, usually 3-celled and 3-winged or 3-horned; placentae usually axile, simple or divided; fruit usually capsular.

\section{BEGONIA L.}

General characters of the family, of which it contains more than 90 per cent of the species; tepals free, usually 4 in two pairs, in staminate flowers, and 5 in 
pistillate flowers; placentae simple or divided; fruit usually bearing 3 unequal wings.

About 800 species. Nearly pantropical. We take the following from Standley's notes: “The species or varieties of Begonia grown in Guatemalan gardens or as pot plants are numerous. They are largely those seen commonly in the United States and are probably of South American origin. It is noteworthy that of all native Central American species only $B$. heracleifolia has much if any importance as an ornamental plant. Most of the others are decidedly inferior in ornamental value, and many of them decidedly unattractive. Rex begonias are noticed frequently as pot plants, especially in the mountains, but they must be protected from wind and rain. The cultivated plant known in the United States as Begonia rubra [a form or hybrid of $B$. maculata Raddi] is a common garden plant of Guatemala. In the gardens of Cobán the plants of this species often rise well above the garden walls."

Plants acaulescent or subacaulescent with the leaves clustered near the apex of the stem, or with slender creeping rhizomes if the internodes elongate.

Leaves peltate.

Petiole with a ring of large lacerate scales at its summit and usually several more rings below; inflorescence of many small flowers; capsule-wings

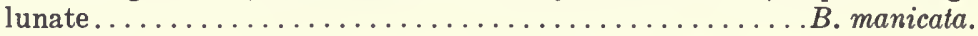

Petiole glabrous or if pubescent the indument not in rings.

Inflorescence regularly cymose, about as broad as long.

Leaves $17-40 \mathrm{~cm}$. long; inflorescence many-flowered...B. nelumbiïfolia. Leaves 5-10 cm. long; inflorescence few-flowered.

Staminate and pistillate tepals 2, suborbicular; the only capsule-wing narrow, falcate-ascending.................. Calderonii.

Staminate tepals 4 , narrowly elliptic; pistillate tepals 5; largest capsule-wing ovate........................ sciadiophora.

Inflorescence strongly unilateral, elongate; staminate tepals 4 , pistillate tepals $5 \ldots \ldots \ldots \ldots \ldots \ldots \ldots \ldots \ldots \ldots \ldots . \ldots \ldots$ militaris.

Leaves basifixed.

Leaves palmately compound..................... caroliniifolia.

Leaves simple.

Leaves deeply palmate-lobed.

Inflorescences strongly unilateral.

Flowers appearing with the leaves; bracts persistent..B. heracleifolia.

Flowers appearing before the leaves; bracts deciduous. . B. crassicaulis.

Inflorescences scarcely or not at all unilateral; flowers appearing with the leaves; bracts deciduous.

Stipules deciduous; staminate tepals 4; pistillate tepals 3; fruit deflexed with largest wing basal....................... acutiloba.

Stipules persistent; staminate tepals 2 or rarely 4 ; pistillate tepals 2 or rarely 3 ; fruit erect with largest wing central.....B. Lindleyana.

Leaves not lobed or with the lobes few and superficial. 
Pistillate tepals 4, subequal; capsule-wings rounded, unequal to subequal; petiole tomentose..................... pinetorum.

Pistillate tepals 2 , or if 3 with the inner one much reduced.

Capsules erect or suberect (imperfectly known in $B$. confusa); leaves never bullate.

Petiole with a ring of large lacerate scales at its summit and usually several more rings below; inflorescence of many small flowers; capsule-wings lunate, subequal.............. manicata.

Petiole glabrous or the indument not in rings.

Indument of the petioles consisting of fimbriate scales.

Largest capsule-wing narrower than high; anthers longer than the filaments; leaves entire or slightly serrate. . B. strigillosa.

Largest capsule-wing wider than high; anthers much shorter than the filaments; leaves ciliate-denticulate. .B. stigmosa.

Indument of the petioles, if any, consisting of simple linear trichomes.

Tepals fleshy, at least the outer ones bearing some indument.

Leaves oblique, up to $6 \mathrm{dm}$. long, petioles $2-4 \mathrm{dm}$. long, densely retrorse-pilosulous; largest capsule-wing dolabriform or subovate, $25-30 \mathrm{~mm}$. wide. . . . . . . B. fusca.

Leaves straight, not over $18 \mathrm{~cm}$. long, petioles $16-23 \mathrm{~cm}$. long, sparsely pilose; internodes 1-9 cm. long, not over $5 \mathrm{~mm}$. thick . . . . ....................... confusa.

Tepals thin, wholly petaloid, glabrous or (in B. Lindleyana) with an evanescent pubescence.

Stipules 1-nerved, thin; capsule-wings subequal, all narrowly lunate, rounded; tepals bright red......... B. tinctoria.

Stipules with many thick nerves; capsule-wings usually very unequal, at least the largest somewhat angled.

Cyme nearly or quite regular; petioles more or less fuscouslanate..................... Lindleyana.

Cyme strongly unilateral; petioles usually soon glabrous.

B. plebeja.

Capsules reflexed (imperfectly known in $B$. confusa), with one wing very large; stem usually slender and repent with distinct internodes.

Leaves bullate, broadly ovate, oblique............ pustulata. Leaves not bullate.

Leaves symmetric, straight, cordate-ovate, undulate but not lobed; stipules lacerate. . . . . . . . . . . . . . B. trichosepala.

Leaves asymmetric at least at base, mostly oblique, sometimes lobed.

Petioles densely pilosulous or hirsute; leaves ample, 1-6 dm. long, deeply cordate at base, shallowly if at all lobed.

Cymes much-branched; leaves shallowly lobed..... B. fusca.

Cymes few-branched; leaves not lobed.........B. Popenoei.

Petioles sparsely pilose to glabrous; leaves mostly lobed.

Tepals glabrous; stipules mostly persistent. . . . . . B. ludicra.

Tepals pubescent; stipules deciduous. 
Leaves straight, broadly ovate, shallowly and bluntly fewlobed; outer tepals covered with dark red septate trichomes.............................. confusa.

Leaves obliquely elliptic, deeply and sharply lobed; tepals puberulent..............................

Plants caulescent with erect or ascending stems and distinct internodes.

Leaves peltate, densely pale-lanate at least beneath ............ peltata. Leaves basifixed.

Ovary bearing 3 equal, narrowly triangular acuminate horns; leaves oblique,

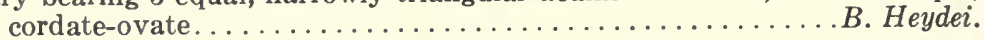

Ovary bearing broad or marginiform, usually unequal wings.

Leaves symmetric, ovate, very sparsely undulate-serrate to entire; staminate tepals 4 , pistillate $5 \ldots \ldots \ldots \ldots \ldots \ldots \ldots \ldots \ldots \ldots \ldots \ldots \ldots$ glabra.

Leaves asymmetric, usually oblique.

Anthers spherical or obovoid; staminate tepals 4 ; pistillate tepals usually 5 , rarely 3 (not known in $B$. cebadillensis).

Pistillate tepals 3 ; capsule-wings subequal, narrow ........ o. oxacana. Pistillate tepals 5 (unknown in $B$. cebadillensis).

Tepals glabrous; inflorescence 1- (rarely 2-) flowered.

Outer staminate tepals broadly reniform, entire; stipules and bracts minute, scarious, deciduous........... cebadillensis.

Outer staminate tepals broadly ovate or elliptic, of ten serrate; stipules and bracts large, foliaceous, colored, persistent.

$B$. gracilis.

Tepals pubescent, the outer serrate; inflorescence usually severalflowered; bracts deciduous.

Stipules deciduous.................... biserrata.

Stipules persistent, foliaceous................ ignea.

Anthers much longer than broad; staminate tepals 2-4; pistillate tepals 2, 3 or 5 .

Bracts persistent, incised; pistillate tepals 5 .

Capsule-wings subequal; seeds obtuse; stamens on a column.

B. Franconis.

Capsule-wings very unequal, the largest being broadest well above the middle; seeds acuminate; stamens free......... Fischeri.

Bracts deciduous; pistillate tepals 2 or 3.

Cymes few-flowered (not truly erect-caulescent types but sometimes may be confused with them).

Tepals glabrous; stipules mostly persistent.......... B. ludicra.

Tepals pubescent; stipules deciduous........... acutiloba.

Cymes many-flowered.

Leaves pinnate-nerved, obliquely elliptic. .....B. convallariodora. Leaves palmate-nerved.

Lobes of the leaf narrowly triangular, acuminate, denticulate; ultimate branches of the inflorescence nearly aborted, making the flowers appear umbellate; largest capsule-wing spreading, elliptic or falcate............ involucrata.

Lobes of the leaf short and broad, entire; branches of the inflorescence well developed; largest capsule-wing ovate. 
Begonia acutiloba Liebm. Vid. Medd. Kjoebenhavn 1852: 14. 1853; emend. Smith \& Schubert, Contr. Gray Herb. 161: 28, t. 3. 1946.

Forested slopes, 1,800-2,000 meters; Huehuetenango (Cerro Chiblac, between Ixcan and Finca San Rafael, Sierra de los Cuchumatanes, Steyermark 49379). Southern Mexico.

Herbaceous; rhizome erect or repent with very short to distinct internodes, glabrous, purplish red; stipules deciduous, not known; petioles $15-24 \mathrm{~cm}$. long, moderately hirsute, becoming less so; leaf-blades asymmetric, obliquely elliptic, sinuate-lobate with about 5 acuminate lobes, cordate at base, 20-30 cm. long, irregularly denticulate, rufous-hirsute on the nerves beneath; peduncles $25-30 \mathrm{~cm}$. long, puberulent; cymes regular, few-flowered; bracts quickly deciduous, ovateoblong, obtuse, entire, thin, glabrous; pedicels 1-2 cm. long, rufous-puberulent; staminate tepals 4 , entire, white, the outer ovate, obtuse, 10-14 mm. long, pubescent with light brown trichomes, the inner narrowly obovate, $6 \mathrm{~mm}$. long; anthers oblong, obtuse; pistillate tepals 3 (only very immature ones known), entire, the two outer ovate, densely tomentose, the inner one much smaller; styles 3 , bifid; capsule deflexed, ellipsoid, unequally 3-winged, the largest wing subbasal, oblong, obtuse, half the height of the capsule.

Begonia biserrata Lindl. Journ. Hort. Soc. 2: 313. 1847; Hook. Bot. Mag. 79: t. 4746. 1853. Knesebeckia biserrata Klotzsch, Begon. 45. 1855. Begonia palmaris A. DC. Ann. Sci. Nat. sér. 4, 11: 126. 1859. B. palmata Sessé \& Mociño, Pl. Nov. Hisp. 163. 1890, not Don.

Moist thickets and forests, 1,400-2,000 meters; Chiquimula; Santa Rosa; Guatemala; Quiché; Huehuetenango. Southern Mexico.

Herbaceous, 6-9 dm. high, apparently dioecious; stem erect, usually simple, pubescent, internodes elongate; stipules soon deciduous; petioles 1-13 cm. long; leaf-blades obliquely palmate with 4 major nerves and 4-6 acute to acuminate lobes, cordate with a cuneate to truncate center, to $19 \mathrm{~cm}$. broad and nearly as long, sharply and doubly serrate, nearly concolorous, pubescent on both sides; inflorescence unilateral, peduncles in the axils of reduced leaves, $15-65 \mathrm{~mm}$. long, 2-6-flowered; bracts rapidly deciduous, ovate or lanceolate, acute, $6 \mathrm{~mm}$. long, serrulate; pedicels hirsute, to $25 \mathrm{~mm}$. long; flowers more or less nodding; staminate tepals 4 , serrate, the outer broadly ovate, $10-25 \mathrm{~mm}$. long, pubescent, the inner lanceolate, much smaller; stamens numerous in a spherical cluster, filaments much longer than the subspherical anthers, connective not produced; pistillate flowers bracteolate, tepals 5 with 3 large outer ones, like the staminate; ovary 3 -celled, placentae bifid, ovuliferous on all sides, styles connate at base, bifid with the stigmatic surface linear, spiral and continuous; capsule ellipsoid, $15-17 \mathrm{~mm}$. long, pubescent, wings oblong, obtuse, unequal, the largest $17 \mathrm{~mm}$. wide; seeds ellipsoid, blunt.

Begonia Calderonii Standl. Field Mus. Bot. 8: 27. 1930 (type from El Salvador, Calderón 2416). B. falcata Smith \& Schubert, 


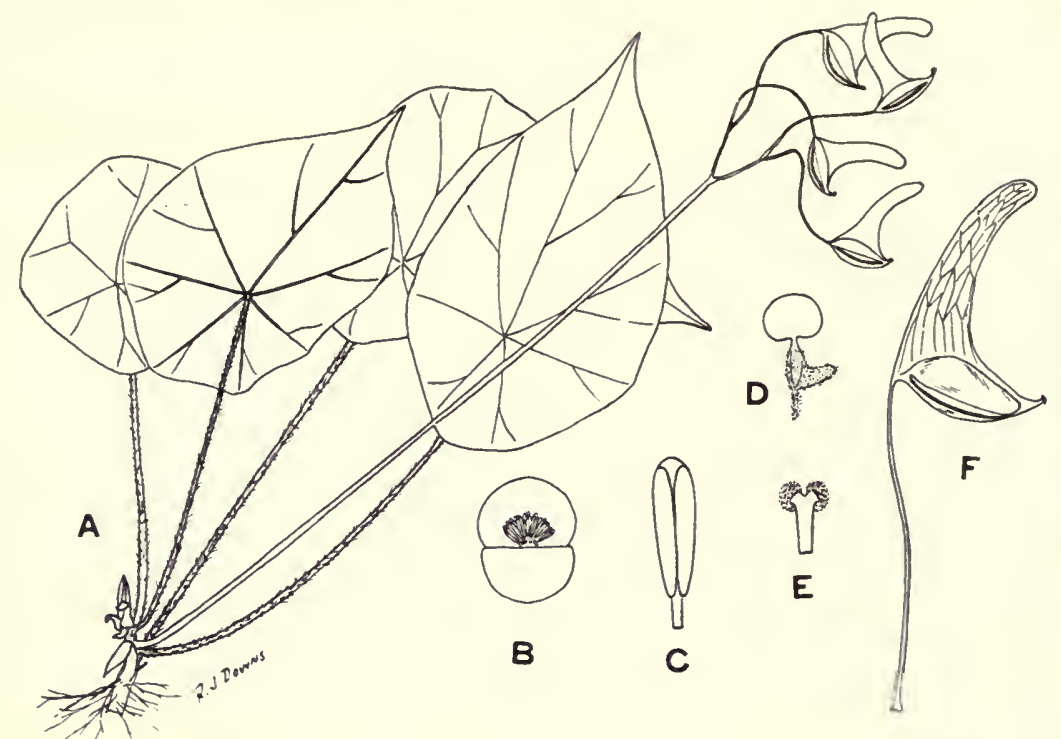

FIG. 18. Begonia Calderonii. A, Habit; $\times 1 / 2 . \quad$ B, Staminate flower; $\times 1$. C, Stamen; $\times 5$. D, Pistillate flower; $\times 1$. E, Style; $\times 5$. F, Fruit; $\times 1$.

Contr. Gray Herb. 127: 28, t. 2, figs. 19-21. 1939 (type from Suchitepéquez, Skutch 1485).

In forest usually on rocks, 1,250-2,000 m.; Zacapa; Sacatepéquez; Chimaltenango; Suchitepéquez; Quezaltenango; San Marcos. El Salvador. Figure 18.

Herbaceous; rhizome branching, 3-5 $\mathrm{mm}$. thick, the younger parts rufoushirsute, internodes evident, up to $3 \mathrm{~cm}$. long; stipules lanceolate, acuminate with a long soft bristle at apex, 7-12 mm. long, membranaceous, ferrugineous, subglabrous; petioles very slender, erect, $7-18 \mathrm{~cm}$. long, sparsely rufous-hirsute with slender septate trichomes $2 \mathrm{~mm}$. long; leaf-blades peltate, ca. 7-nerved, broadly ovate or elliptic, rather abruptly acuminate, broadly rounded at base, $5.5-10 \mathrm{~cm}$. long, 3-6 cm. wide, sometimes very slightly lobed, entire or obscurely denticulate, green and glabrous above, paler beneath and rufous-hirsute especially on the nerves; peduncles nearly $2 \mathrm{dm}$. long, equaling or exceeding the leaves; inflorescence cymose, few-flowered, bisexual, bracts deciduous, unknown, pedicels $15-20 \mathrm{~mm}$. long, glabrous or hirsute; staminate tepals $2,6-10 \mathrm{~mm}$. long, 7-13 $\mathrm{mm}$. wide, suborbicular, cordate at base, entire, subfleshy, white, obscurely nerved; stamens numerous, anthers oblong, filaments short; pistillate flowers ebracteolate, tepals 2, suborbicular, 9-11.5 $\mathrm{mm}$. long, 11-12 $\mathrm{mm}$. wide; ovary slightly hirsute, styles 3, 2-parted, placentae bilamellate, capsule decurved, subellipsoid, the single wing falcate, obtuse, $15-20 \mathrm{~mm}$. long, 5-6 mm. wide.

Begonia caroliniifolia Regel, Gartenfl. 1: 259, t. 25. 1852. $B$. rotata Liebm. Vid. Medd. Kjoebenhavn 1852: 11. 1853. Gireoudia 
caroliniaefolia Klotzsch, Monatsber. Akad. Berlin 125. 1854. G. rotata Klotzsch, Begon. 91. 1855.

Epiphytic and on boulders, 100-1,200 meters; Izabal; Huehuetenango. Southern Mexico.

Herbaceous; rhizome erect or prostrate, 3-6 dm. long, fleshy, $2 \mathrm{~cm}$. or more thick, knobby, white-tuberculate, setose when young but later glabrous, internodes very short; stipules deciduous, ovate, acuminate, entire, ferruginous-villous; petioles erect, stout, 15-60 $\mathrm{cm}$. long, rufous-pilose when young but soon glabrous; leafblade palmately compound, leaflets petiolulate for 1-5 $\mathrm{cm}$., asymmetric, simple or with one lateral lobe toward apex, linear-lanceolate, cuneate, acuminate, 1-3 $\mathrm{dm}$. long, 1-7 cm. wide, thin, rufous-villous beneath when young, margin undulate, setose; peduncle exceeding the leaves, to $85 \mathrm{~cm}$. long, stout, soon glabrous; inflorescence irregularly cymose with one primary branch tending to elongate and make the other appear lateral, many-flowered, to $14 \mathrm{~cm}$. long, lax, soon glabrous, bisexual; bracts deciduous, elliptic, obtuse, $8-12 \mathrm{~mm}$. long, pilose, entire; pedicels slender, 5-18 mm. long; staminate tepals 2, suborbicular, 6-8 mm. long, pink or white; stamens rather numerous, filaments shorter than the oblong anthers, connective produced, short, blunt; pistillate flowers ebracteolate, tepals like the staminate; ovary 3-celled, placentae bifid, ovuliferous on all sides, styles tardily deciduous, nearly free, the stigmatic surface lunate-capitate at their apices; capsule more or less nodding but not sharply reflexed, suborbicular, $8-10 \mathrm{~mm}$. long, wings very unequal, the largest $20 \mathrm{~mm}$. wide, $15 \mathrm{~mm}$. high, nearly truncate above, rounded below; seeds ellipsoid, blunt.

\section{Begonia cebadillensis Houghton ex Smith \& Schubert, Contr. Gray Herb. 161: 26, t. 3. 1946.}

Wet, shady quebrada, 900-950 meters; Santa Rosa (Standley 78204). El Salvador.

Erect caulescent herb; stipules deciduous, lanceolate, acuminate, ciliatelacerate, $2 \mathrm{~mm}$. long, petioles slender, to $7 \mathrm{~cm}$. long, leaves strongly oblique, subelliptic, acuminate, sublobate, shallowly cordate at base, to $4 \mathrm{~cm}$. long and $9 \mathrm{~cm}$. wide, dentate, sparsely puberulent on both sides; peduncles axillary, much shorter than the leaves; inflorescence 1-few-flowered; bracts deciduous, like the stipules; pedicels $6-23 \mathrm{~mm}$. long, sparsely glandular; staminate tepals 4 , entire, rose, the
outer broadly reniform, to $10 \mathrm{~mm}$. long, about twice as long as the stamens, the inner narrowly elliptic, about equaling the stamens; stamens many on a short column, anthers obovoid, much shorter than the filaments; pistillate tepals unknown; styles persistent, articulate, short-bilobate, placentae bilamellate, ovuliferous throughout; capsule oblong-ellipsoid, unequally 3 -winged, the wings tri-
angular.

Begonia confusa Smith \& Schubert, Contr. Gray Herb. 161: 27, t. 3. 1946.

Creeping on rocks, 1,200-2,000 meters; Huehuetenango (type from Sierra de los Cuchumatanes, Steyermark 49185). 
Herbaceous; rhizome slender, prostrate, red, glabrous, internodes $1-9 \mathrm{~cm}$. long; stipules deciduous, lance-oblong, entire, $23 \mathrm{~mm}$. long, pilose, petioles erect, 16-23 cm. long, sparsely pilose, blades straight, asymmetric, broadly ovate, acuminate, 1-3-lobed, cordate at base, to $18 \mathrm{~cm}$. long, entire or sparsely denticulate, sparsely puberulent on both sides, more densely on the nerves beneath; young peduncles much shorter than the leaves; cymes few-flowered, regular, dense when young; bracts deciduous, elliptic, entire, membranaceous, the lowest $12 \mathrm{~mm}$. long; pedicels about $10 \mathrm{~mm}$. long; staminate tepals 2 , broadly ovate, obtuse, entire, red-puberulent, $12 \mathrm{~mm}$. long; stamens numerous, anthers oblong, longer than the filaments, connective produced, obtuse; pistillate flowers probably ebracteolate, only very young ones known; tepals 3 , the outer ones broadly ovate, fleshy, redpuberulent, the inner one much smaller, elliptic, glabrous; styles 3, bifid; ovary unequally 3-winged, pubescent, the wings ascending.

Begonia convallariodora C. DC. Bot. Gaz. 20: 538. 1895; Smith \& Schubert, Ann. Mo. Bot. Gard. 45: 67, fig. 20. 1958.

Thickets or moist forest, sometimes epiphytic (Panama), 1,2501,350 meters; Alta Verapaz (type from Pansamala, von Tuerckheim 886); Huehuetenango. Southern Mexico to Panama. Figure 19.

Scandent to erect herb 1-4 m. high with little-branched slender stem, glabrous; stem ribbed, internodes of main axis 5.5-14 cm. long; stipules somewhat persistent, obliquely elliptic, membranaceous, base truncate and apex acute and apiculate, entire, $25 \mathrm{~mm}$. long, $7 \mathrm{~mm}$. wide; petioles $12-40 \mathrm{~mm}$. long; leaf-blades asymmetric, obliquely elliptic, pinnately veined, abruptly acuminate, base usually with broader half produced into a conspicuous lobe, $8.5-15 \mathrm{~cm}$. long, $4-7.5 \mathrm{~cm}$. wide, more or less denticulate; peduncles $3-8 \mathrm{~cm}$. long; cymes many-flowered, regular; bracts very early deciduous; pedicels $6-16 \mathrm{~mm}$. long; staminate tepals entire, white or pinkish, 2 or less often 3 or 4 , the outer orbicular, cordate at base, $4-8 \mathrm{~mm}$. long, the inner elliptic, 1-3.5 mm. long; stamens many, anthers oblong-elliptic, longer than the filaments, connective produced, obtuse; pistillate bracteoles early deciduous, elliptical, entire, acute; tepals entire, 2 or less often 3 , the outer orbicular to rounded ovate, 6-9 $\mathrm{mm}$. long, the third much smaller; styles 3 , bifid; placentae bilamellate, ovuliferous throughout; capsule ellipsoid, unequally 3 -winged, the largest wing obtuse, 7-12 $\mathrm{mm}$. wide.

\section{The flowers are said to smell like Convallaria, hence the name.}

Begonia crassicaulis Lindl. Bot. Reg. 28: misc. 22, t. 44. 1842.

Thickets or forest, sometimes epiphytic, 1,300-1,400 m. Endemic. Figure 20.

Herbaceous; rhizome short, simple or with very short bulbous branches, 3-4 $\mathrm{cm}$. thick, pilose, soon glabrous, internodes very short; leaves developing after the flowers, stipules triangular, acuminate, 15-25 mm. long, entire, brown, thin, petioles erect, elongate, fuscous-lanate at least when young, leaf-blades palmately 5-7-lobed about half-way to base, $12-22 \mathrm{~cm}$. wide, sinuate-dentate with acute or acuminate lobes, fuscous-lanate beneath at first, peduncles erect, 7-30 cm. long, fuscous-lanate; inflorescence unilaterally cymose so that the larger side appears 


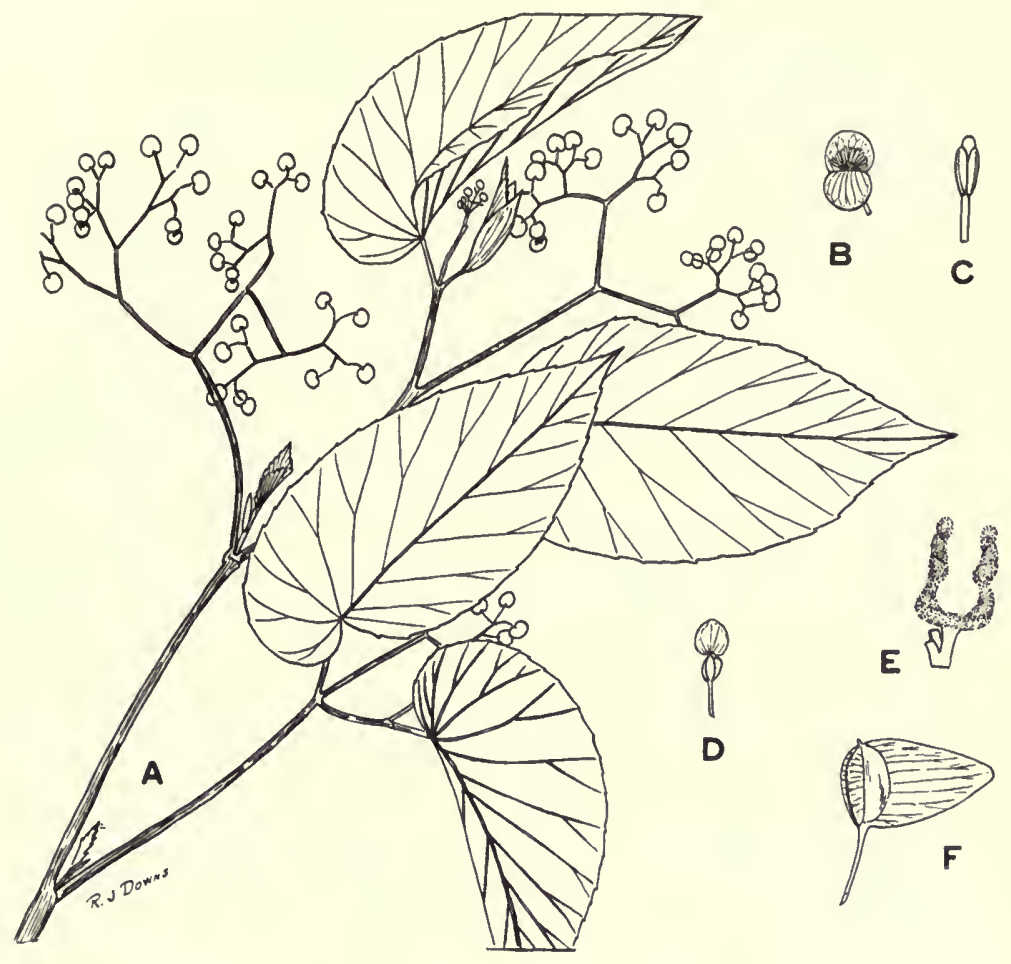

Fig. 19. Begonia convallariodora. A, Branch; $\times 1 / 2 . \quad$ B, Staminate flower; $\times 1$. C, Stamen; $\times 5$. D, Pistillate flower $\times 1$. E, Style; $\times 5$. F, Fruit; $\times 1$.

to be a continuation of the peduncle; bracts quickly deciduous, broadly elliptic, obtuse, $10 \mathrm{~mm}$. long, serrulate; pedicels slender, 6-11 mm. long; staminate tepals 2, suborbicular, 6-10 mm. long, white or rose; stamens numerous, anthers oblong; pistillate flowers with 2 large ample deciduous bracts at base; tepals 2, like the staminate; ovary 3-celled, placentae bifid, ovuliferous on all sides; styles connate at base, stigmatic papillae lunate-capitate at their apices; capsule erect or somewhat nutant, ellipsoid, 12-16 mm. long, wings slightly unequal, the largest ovate, subacute, $8 \mathrm{~mm}$. wide, seeds ellipsoid, blunt.

Begonia Fischeri Schrank var. tovarensis (Klotzsch) Irmscher, Bot. Jahrb. 76: 23. 1953; Smith \& Schubert, Ann. Mo. Bot. Gard. 45: 57, f. 17. 1958. B. tovarensis Klotzsch, Begon. 31. 1855. B. Moritziana Klotzsch, l.c., not Kunth \& Bouché 1848.

Swamps, 50-1,700 meters; Petén; Alta Verapaz; Baja Verapaz; Izabal; Santa Rosa; Sacatepéquez; Chimaltenango. Southern Mexico and Cuba to Venezuela, Bolivia and Peru. 

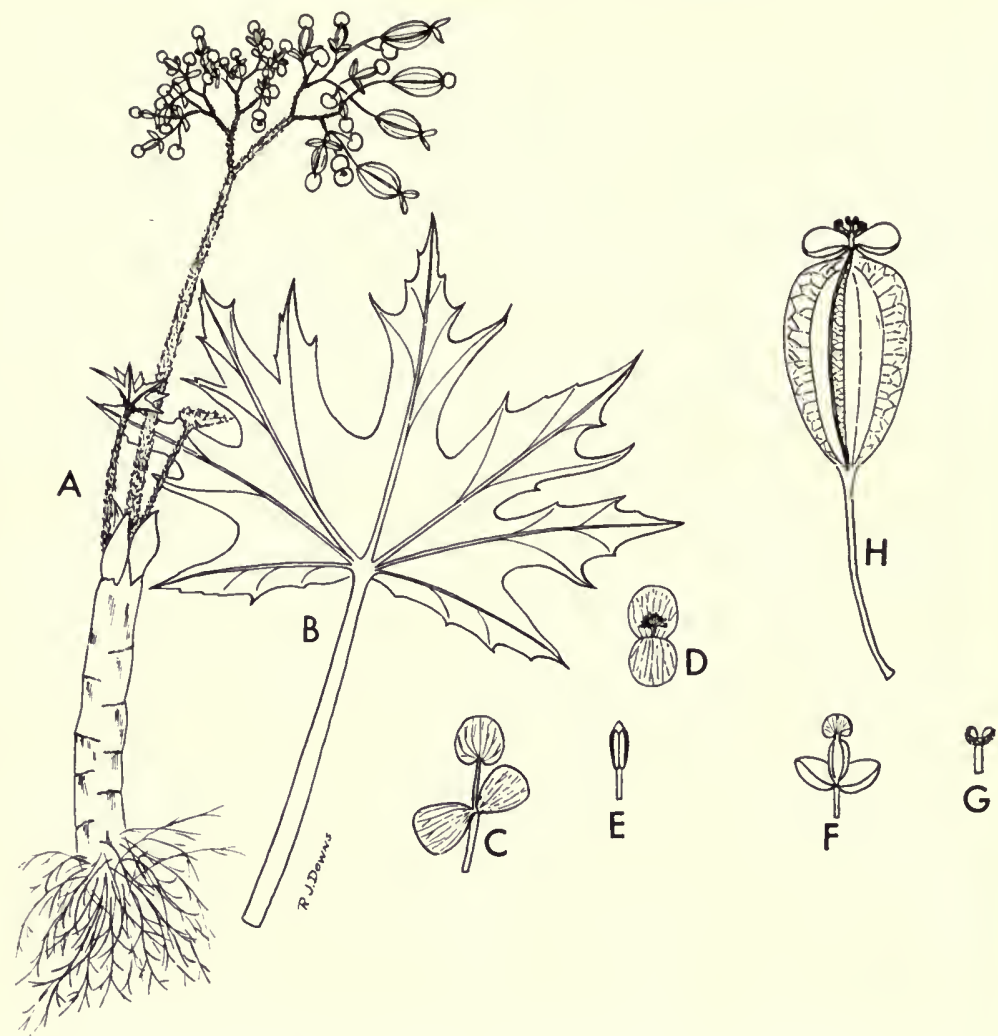

FIG. 20. Begonia crassicaulis. A, Habit; $\times 1 / 4 . \quad$ B, Leaf; $\times 1 / 2 . \quad$ C, Staminate flower and bracts; $\times 1$. D, Staminate flower opened; $\times 1$. E, Stamen; $\times 5$. F, Pistillate flower and bracts; $\times 1$. G, Style; $\times 5$. H, Fruit; $\times 1$.

Herb, 2-12 dm. high, sparsely brown-pilose to glabrous; stem erect, red; stipules deciduous, ovate-oblong, to $10 \mathrm{~mm}$. long, ciliate-serrulate, petioles 5-60 $\mathrm{mm}$. long, leaf-blades more or less asymmetric, broadly ovate or suborbicular, acute or rounded, cordate at base, $2-9 \mathrm{~cm}$. long, palminerved, crenate-serrate, ciliate, nearly or quite glabrous above, sparsely hirsute beneath; peduncles axillary, 15-45 mm. long; cymes few-flowered; bracts persistent, ovate, $2-4 \mathrm{~mm}$. long, fimbriate; pedicels 5-17 mm. long; staminate tepals 4 , the outer orbicular, $8 \mathrm{~mm}$. long, the inner smaller, narrowly obovate; stamens free, numerous, filaments short, anthers oblong; pistillate flowers bracteolate, tepals 5, obovate, 3-6 mm. long; styles 3, 2-parted, the stigmatic tissue linear, spiral, continuous, placentae bilamellate, ovuliferous on all sides; capsule ellipsoid, 10-15 $\mathrm{mm}$. long, its wings decurrent, very unequal, the largest usually ascending, tapering and of ten hooked, to $23 \mathrm{~mm}$. wide, seeds curved with attenuate apices.

Begonia Franconis Liebm. Vid. Medd. Kjoebenhavn 1852: 21. 1853. B. modesta Liebm. l.c. 20. 

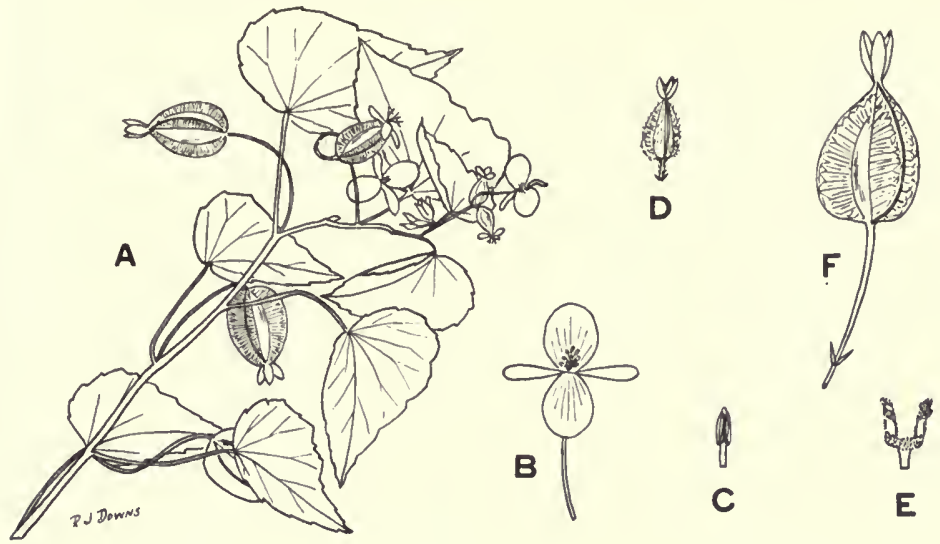

FIG. 21. Begonia Franconis. A, Partial habit; $\times 1 / 2 . \quad$ B, Staminate flower; $\times 1$. C, Stamen; $\times 5$. D, Pistillate flower; $\times 1$. E, Style; $\times 5$. F, Fruit; $\times 1$.

On rocks, 1,100 meters; Alta Verapaz. Southern Mexico. Figure 21.

Herbaceous annual, caulescent, branching, 5-50 cm. high, stem with mixed coarse and fine pubescence, erect or decumbent at base; stipules persistent, lanceolate, acute, 2-3 mm. long, ciliate, petioles slender, 5-70 $\mathrm{mm}$. long, leaf-blades obliquely ovate, acute, cordate to subtruncate at base, $3.5-8 \mathrm{~cm}$. long, crenatedentate, ciliate, thin; peduncles axillary, 1-few-flowered, to $3 \mathrm{~cm}$. long; bracts persistent, ovate, acute, $1.5-2 \mathrm{~mm}$. long, lacerate; pedicels $4-10 \mathrm{~mm}$. long, filiform; staminate tepals 4 , entire, rose or white, the outer broadly ovate or orbicular, 3.5-7 mm. long, the inner elliptic, shorter; stamens few on a column, anthers ellipsoid, shorter than the filaments; pistillate bracteoles subulate, minute; pistillate tepals 5, subequal, elliptic; styles 3, bilobed, placentae simple; capsule ovoid or ellipsoid, with the lunate, subequal wings broadest at the top, middle or base and much extended above the locules; seeds obtuse.

Begonia fusca Liebm. Vid. Medd. Kjoebenhavn 1852: 7. 1853. B. maxima Klotzsch, Begon. 39. 1855, nomen, in synon. Magnusia fusca (Liebm.) Klotzsch, Begon. 102. 1855, and M. fusca Klotzsch, l.c. 103, t. 9, C, figs. a-m. M. maxima Klotzsch, 1.c. Begonia Johnstonii Standl. ex J. R. Johnston, Cat. Plant. Guatemala 12. 1938, nomen (type from Alta Verapaz, Johnston 1152). Flor de mano de león de peñasco (fide Steyermark).

Epiphytic or terrestrial on shady slopes, 1,300-2,500 meters; Alta Verapaz; Baja Verapaz; Zacapa; Huehuetenango; Quezaltenango; San Marcos. Southern Mexico.

Herbaceous, to $15 \mathrm{dm}$. high (Steyermark!); rhizome procumbent or oblique, 15-40 mm. thick, setose (Klotzsch!), with very short internodes or sometimes 
only about $5 \mathrm{~mm}$. thick and with distinct internodes; stipules deciduous, broadly ovate, subacuminate, pilose at first, serrate-setose (Klotzsch!) or entire; petioles erect, $2-4 \cdot \mathrm{dm}$. long, densely retrorse-pilosulous; blades oblique, very broadly ovate or suborbicular, abruptly acuminate, of ten with several superficial acuminate lobes beside the apex, cordate, up to $6 \mathrm{dm}$. long (Standley!), palmately 7-9-nerved, angulate-dentate, ciliate-serrate, thin, finely pubescent on both sides; peduncle exceeding the leaves, to $6 \mathrm{dm}$. long, 5-10 $\mathrm{mm}$. thick, pilosulous at first; cyme regular, much branched, 2-5 dm. long, pubescent; bracts deciduous, suborbicular, pubescent, the upper ones entire, thin, the lower ones over $4 \mathrm{~cm}$. long, sometimes serrulate; pedicels slender, $1-4 \mathrm{~cm}$. long, pubescent; staminate tepals 2 , broadly ovate or suborbicular, subacute or obtuse, 6-11 mm. long, fleshy, sparsely pilose, pink or white; stamens numerous, filaments shorter than the oblong anthers, connective produced into a broad flat cap above the anther; pistillate tepals 2 or sometimes a third and much smaller one inside the others, like the staminate but much smaller; ovary 3-celled, placentae bifid, ovuliferous throughout, styles deciduous, slightly connate at base, bifid, the stigmatic surface linear, spiral, continuous; capsule more or less nutant, broadly ovoid, pubescent at first, $8-12 \mathrm{~mm}$. long, wings very unequal, the largest dolabriform or subovate, $25-30 \mathrm{~mm}$. broad.

Begonia glabra Aubl. Pl. Guian. 2: 916, t. 349. 1775; Smith \& Schubert, Ann. Mo. Bot. Gard. 45: 54, f. 17. 1958. B. scandens Sw. Prodr. 86. 1788. B. elliptica HBK. Nov. Gen. \& Sp. 7: 180, t. 641. 1825. B. lucida Otto \& Dietr. Allg. Gartenz. 16: 162. 1848. B. Moritziana Kunth \& Bouché, Ind. Sem. Hort. Berol. 16. 1848. B. physalifolia Liebm. Vid. Medd. Kjoebenhavn 1852: 19. 1853. Wageneria glabra Klotzsch, W. Moritziana Klotzsch and W. lucida Klotzsch, Monatsber. Akad. Berlin 126. 1854. W. deflexa Klotzsch, Begon. 113. 1855. W. montana Klotzsch, l.c. 115. Begonia locellata A. DC. Ann. Sci. Nat. sér. 4. 11: 137. 1859.

Epiphytic and terrestrial in forest, 75-1,300 meters; Petén; Alta Verapaz; Izabal; Suchitepéquez; Huehuetenango; Quezaltenango; San Marcos. Southern Mexico and the West Indies to Peru and Bolivia.

Stem scandent, rooting at the nodes, glabrous; stipules persistent, ovateoblong, setiferous at apex, entire, 10-22 mm. long, petioles 1-8 cm. long, leafblades variable, straight, nearly symmetrical, broadly ovate, 4-12 cm. long, short-acuminate, rounded or barely cordate at base, sparsely serrate and ciliate to entire, glabrous; peduncles axillary, 6-12 cm. long; cymes unisexual, manyflowered, diffuse; bracts persistent, minute; pedicels 6-17 $\mathrm{mm}$. long, fine; staminate tepals 4 , entire, white, the outer broadly obovate, $3-6 \mathrm{~mm}$. long, the inner narrower; stamens free, few, anthers oblong; pistillate flowers minutely bracteolate; pistillate tepals 5, elliptic, 4-6 mm. long; styles 3, 2-parted, completely covered by stigmatic papillae, placentae simple; capsule erect, ellipsoid, 6-12 $\mathrm{mm}$. long, the largest wing oblong to deltoid, spreading or barely ascending, 10-23 $\mathrm{mm}$. wide, the other two marginiform, very narrow. 


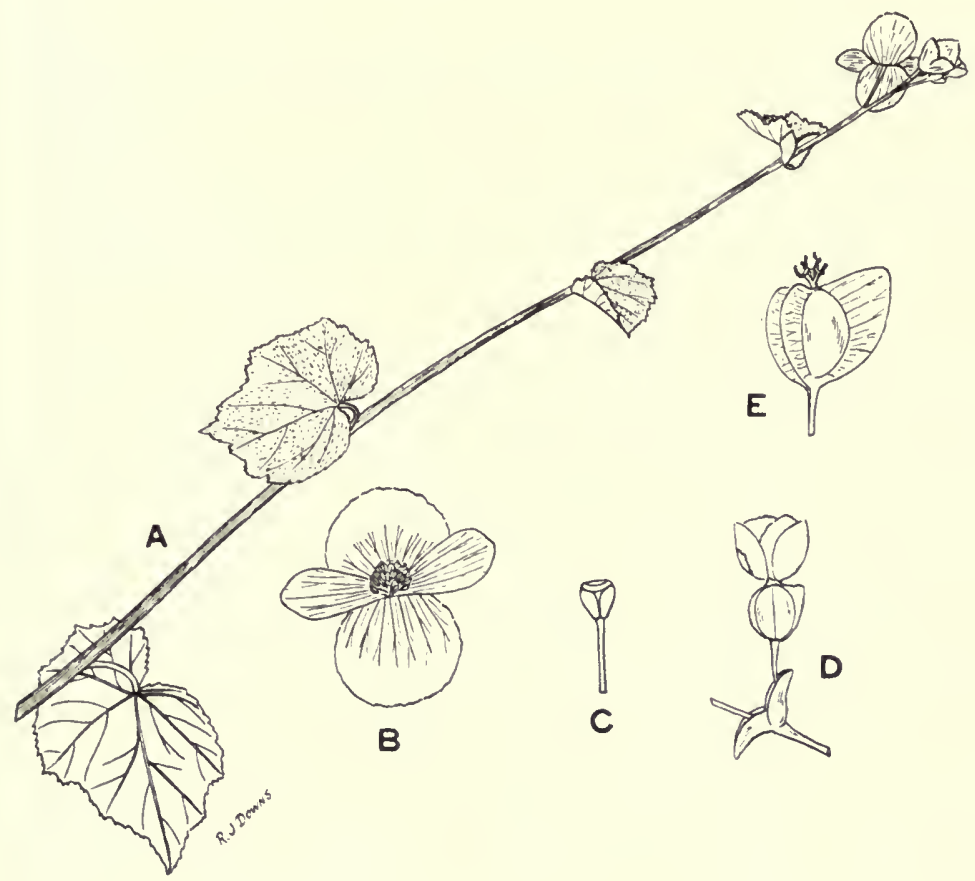

FIG. 22. Begonia gracilis. A, Partial habit; $\times 1 / 2 . \quad$ B, Staminate flower; $\times 1$. C, Stamen; $\times 5$. D, Pistillate flower and bracts; $\times 1$. E, Fruit; $\times 1$.

Begonia gracilis HBK. Nov. Gen. \& Sp. 7: 184. 1825.

Sololá (slopes above San Lucas Tolimán, Volcán Tolimán, Steyermark 47605). Mexico, where it grows in moist forest or sometimes on exposed rocks, at 1,500-2,500 meters. Figure 22.

Herbaceous, erect-caulescent from a tuberous base, very variable; stem pubescent or glabrous, often bearing bulblets in the leaf-axils; stipules persistent, green, oblong, acute, serrulate-ciliate; petioles slender, 1-10 $\mathrm{cm}$. long but the upper ones short; leaves oblique, ovate or elliptic and acute or acuminate, the lowest sometimes reniform, cordate at base, more or less lobed, doubly serrate, 3-12 cm. long, pubescent or glabrous; peduncles 1- (rarely 2-) flowered; bracts persistent, broadly elliptic, serrate; pedicels to $3 \mathrm{~cm}$. long; staminate tepals 4 , pink, glabrous, the outer broadly ovate or elliptic, more or less serrate or entire, 10-22 $\mathrm{mm}$. long, the inner narrowly obovate, shorter, entire; stamens many, on a short column, anthers obovoid, much shorter than the filaments; pistillate flowers ebracteolate; pistillate tepals 5 , like the staminate; styles bifid, placentae bilamellate; capsule ellipsoid, unequally 3 -winged, the largest wing triangular, the others ovate to lunate. 


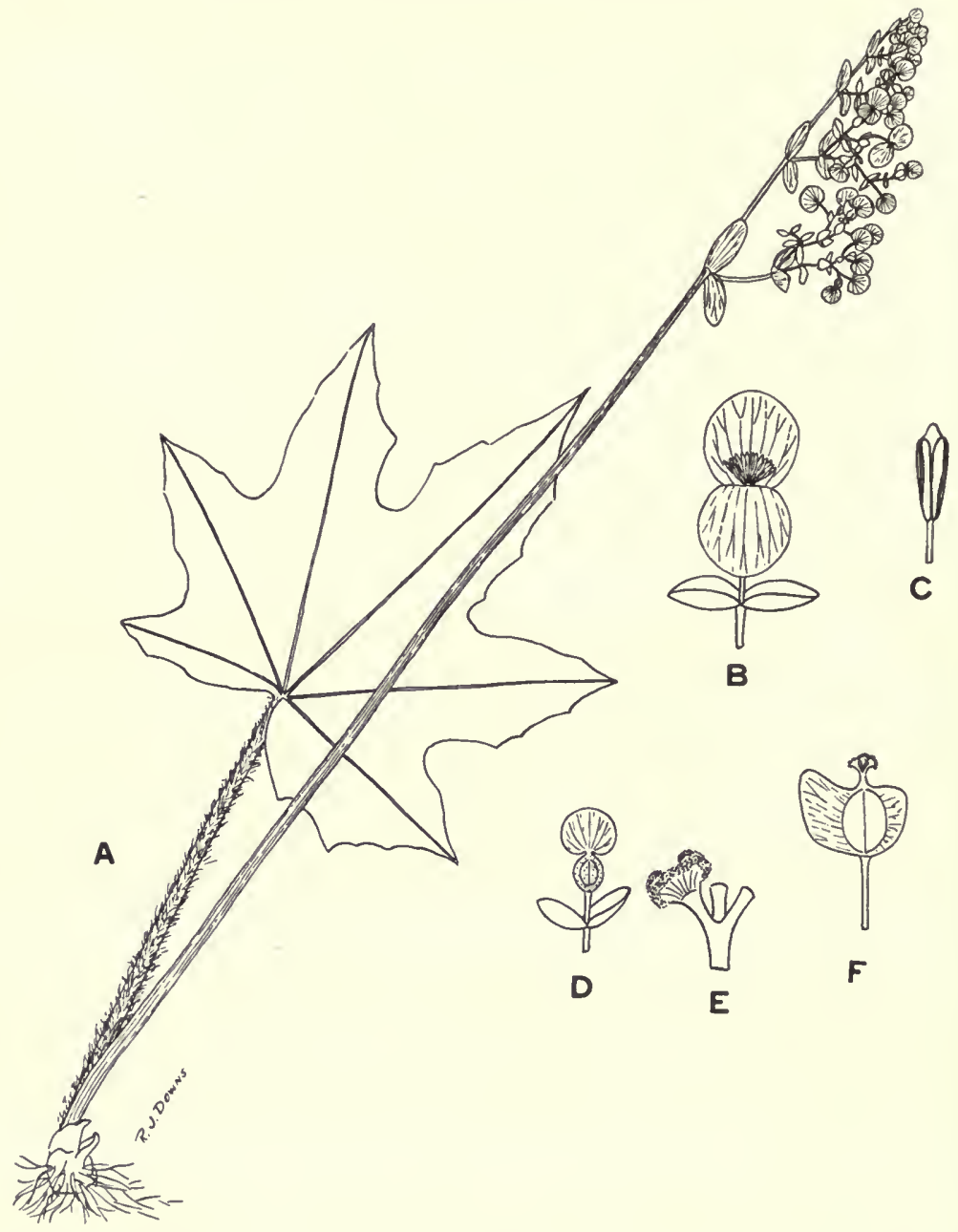

FIG. 23. Begonia heracleifolia. A, Habit; $\times 1 / 4 . \quad$ B, Staminate flower and bracts; $\times 1$. C, Stamen; $\times 5$. D, Pistillate flower and bracts; $\times 1$. E, Style; $\times 5$. F, Fruit; $\times 1$.

Begonia heracleifolia Schlecht. \& Cham. Linnaea 5: 603. 1830. B. radiata R. Graham, in Edinb. Phil. Journ. 182. July 1833. B. punctata Link \& Otto, Ic. Pl. Rar. 1: 16, t. 7. 1840-44. Gireoudia heracleifolia Klotzsch and G. punctata Klotzsch, Monatsber. Akad. Berlin 125. 1854. G. heracleifolia var. a viridis Klotzsch and var. $\beta$ punctata Klotzsch, Begon. 95. 1855. Begonia nigricans Klotzsch, Begon. 1.c., nomen, in synon. B. heracleifolia var. nigricans Hook. Bot. Mag. 83: t. 4983. 1857. B. longipila Lem. Ill. Hortic. 8: t. 30\%. 1861. B. hera- 
cleifolia var. $\beta$ nigricans A. DC., var. $\gamma$ longipila A. DC. and var. $\delta$ punctata A. DC. Prodr. 15, pt. 1: 335. 1864. B. heracleifolia var. Sunderbrucki Hort. ex C. Chevalier, Begon. 268. 1938. Tonichut (Quecchí).

Terrestrial and saxicolous in forests, 50-1,500 meters; Petén; Alta Verapaz; Zacapa; Santa Rosa; Guatemala. Southern Mexico, British Honduras. Figure 23.

Herbaceous, very variable in indument, coloration of leaves, size of inflorescence and form of capsule-wings; rhizome repent, 7-15 cm. long, $2 \mathrm{~cm}$. thick, simple, setose, internodes very short; leaves developing with the flowers, stipules triangular, setose-acuminate, entire, $12-20 \mathrm{~mm}$. long, petioles erect, stout, $3-40$ $\mathrm{cm}$. long, from densely hirsute with slender sometimes divided trichomes to nearly glabrous; trichomes especially large and dense at the apex of the petiole, leafblade palmately 7 -lobed $1 / 2$ to $2 / 3$ toward base, subcordate, $8-26 \mathrm{~cm}$. wide, irregularly sinuate-dentate with acuminate lobes, nearly or quite glabrous above, more or less hirsute beneath on the nerves and margin, thin, green throughout or with broad, nearly black margins; peduncles mostly exceeding the leaves, 2-7 $\mathrm{dm}$. long, more or less hirsute; inflorescence laxly cymose but tending to develop one side much more than the other, bisexual, up to $25 \mathrm{~cm}$. long, many-flowered, sometimes red-punctate; bracts persistent, broadly ovate or elliptic, entire or serrate, green or red, the lowest $2 \mathrm{~cm}$. long; pedicels slender, 8-18 $\mathrm{mm}$. long; staminate tepals 2, suborbicular, 10-14 mm. long, white or rose; stamens numerous, subfree, filaments short, anthers oblong, the connective produced into a broad rounded appendage; pistillate flowers ebracteolate; pistillate tepals 2, like the staminate; ovary 3-celled, placentae bifid, ovuliferous on all sides, styles connate at base, the stigmatic tissue lunate at their apices; capsule erect or somewhat nutant, suborbicular, 8-12 mm. long, wings unequal, the largest ovate with the upper side nearly horizontal, usually subacute, $8-12 \mathrm{~mm}$. wide, seeds ellipsoid, blunt.

Standley says of this species: “A common ornamental plant in Guatemala, in pots and gardens. Wild at many places in the country. The finest display of it that I have ever seen was in Alta Verapaz on the road above Pancajche, where for long distances it covered completely the roadside banks. The display of beautiful pink flowers equaled almost the best that could be produced at horticultural exhibitions in the United States, and gave the effect almost of wellfurnished greenhouse benches."

Begonia Heydei C. DC. Bot. Gaz. 20: 540. 1895 (type from Quiché, Heyde \& Lux 3094); Smith \& Schubert, Ann. Mo. Bot. Gard. 45: 62, f. 18. 1958. B. Pittieri C. DC. Bull. Herb. Boiss. II. 8: 316. 1908. B. triloba C. DC. l.c. 322 (type from Alta Verapaz, von Tuerckheim II1954).

Usually epiphytic in forests, 900-2,100 meters; Alta Verapaz; Quiché; Huehuetenango. Costa Rica; Panama. Figure 24. 


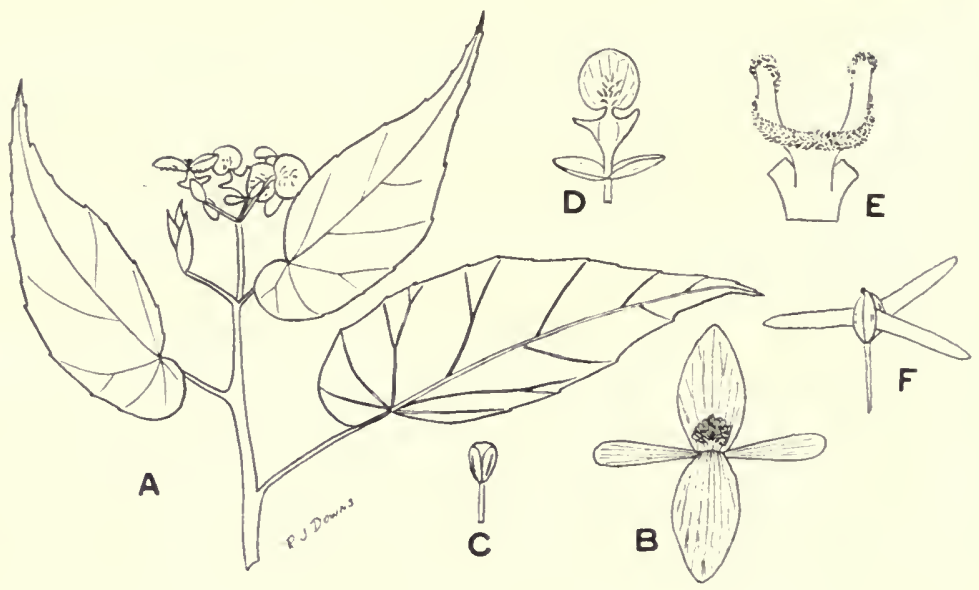

FIG. 24. Begonia Heydei. A, Branch; $\times 1 / 2 . \quad$ B, Staminate flower; $\times 1$. C, Stamens; $\times 5$. D, Pistillate flower and bracts; $\times 1$. E, Style; $\times 5$. F, Fruit; $\times 1$.

Erect, to $6 \mathrm{dm}$. high, branching, glabrous, internodes elongate; stipules deciduous, lance-ovate, subulate, $5 \mathrm{~mm}$. long, petioles $10-34 \mathrm{~mm}$. long, leaf-blades oblique, cordate-ovate, acuminate, $6-10 \mathrm{~cm}$. long, 2-3.5 cm. wide, remotely denticulate; peduncles axillary, 15-28 mm. long; cymes few-flowered, exceeded by the leaves; bracts deciduous; pedicels $8-10 \mathrm{~mm}$. long; staminate tepals 4 , entire, obtuse, the outer ovate or elliptic, $7 \mathrm{~mm}$. long, setose toward base, the inner slightly shorter; stamens many on a short column, anthers obovate, nearly equaling the filaments; pistillate bracteoles elliptic, entire, about equaling the ovary; pistillate tepals 3, elliptic or obovate, entire, setose toward base; ovary 3-celled, placentae simple; styles deciduous, connate at base, bifid; capsule rhomboidal, attenuate at base, bearing three equal slender acuminate horns 9-11 mm. long.

Begonia ignea (Klotzsch) Warsc. ex A. DC. Prodr. 15, pt. 1: 306. 1864 (type from cultivated material from Guatemala, without further locality, Warsczewicz). Knesebeckia ignea Klotzsch, Begon. 46. 1855. Costa Rica.

Caulescent erect herb, 6-9 dm. high, stem glandular-hispid, base subtuberous; stipules persistent, suborbicular, cordate, 6-12 mm. long, serrulate, green, petioles to $12 \mathrm{~cm}$. long, leaf-blades oblique, broadly ovate, sharply 4-6-lobed, cordate at base, 5-14 cm. long, 7-22 cm. wide, serrate, hispid; peduncles axillary, 4-9 $\mathrm{cm}$. long; cymes few-flowered, dichotomous, bracts deciduous, broadly ovate, obtuse, 4-6 mm. long, ciliate, rose; pedicels pilose; staminate tepals 4, rose, the outer ovate, acute, 16-20 mm. long, ciliate-serrulate, pilose, the inner shorter, obovate, obtuse, entire, glabrous; stamens numerous, on a column, anthers obovoid, much shorter than the filaments; pistillate bracteoles like the bracts; pistillate tepals 5 , like the staminate; styles 3 , persistent, irregularly short-branched; capsule ellipsoid, pilose, unequally 3 -winged (!A. DC.), the largest wing obtuse. 
Begonia involucrata Liebm. Vid. Medd. Kjoebenhavn 1852: 15. 1853; Smith \& Schubert, Ann. Mo. Bot. Gard. 45: 60, f. 18. 1958. B. broussonetiaefolia A. DC. Ann. Sci. Nat. sér. 4. 11: 133. 1859 (type from Guatemala, Friedrichsthal). B. laciniosa A. DC. Prodr. 15, pt. 1: 340. 1864 .

Known here only from the type of $B$. broussonetiaefolia, and without further locality than "Guatemala." Nicaragua; Costa Rica; Panama.

Erect, 1-2 m. high, fruticose, stem fulvous-tomentose or becoming glabrous; stipules deciduous, ovate, setose-apiculate, $14-25 \mathrm{~mm}$. long, entire, brown, membranaceous, glabrous or sparsely pilose, petiole $12-18 \mathrm{~cm}$. long, fulvous-tomentose or becoming glabrous; leaf-blades oblique, cordate at base, 2-5-lobed at apex with acuminate points, $15-28 \mathrm{~cm}$. wide, to $20 \mathrm{~cm}$. high, denticulate, evenly pilosulous above, more densely on the nerves beneath; peduncles axillary, exceeding the leaves, fulvous-tomentose, becoming glabrous; cymes many-flowered, dense, their primary branches short and their ultimate branches so nearly aborted that the inflorescence appears almost umbellate; bracts deciduous, the outer ovate, ample and completely enclosing the young inflorescence, pedicels 5-25 mm. long; staminate tepals 2, suborbicular, 6-11 mm. long, entire, sparsely pilose to glabrous, white; stamens numerous, anthers oblong, about equaling the filaments, connective produced, broadly obtuse; pistillate bracteoles lacking; pistillate tepals 2, like the staminate; ovary 3-celled, placentae bilamellate; styles connate at base, bifid; capsule ellipsoid, very unequally 3 -winged, the largest wing elliptic or falcate, obtuse, $8-10 \mathrm{~mm}$. wide.

Begonia Lindleyana Walp. Rep. 2: 209. 1843; Smith \& Schubert, Caldasia 4, no. 16: 11, t. 2. 1946. B. vitifolia Lindl. Bot. Reg. 28: misc. 21. 1842, not Schott 1827. B. sarchophylla Liebm. Vid. Medd. Kjoebenhavn 1852: 12. 1853. B. sericoneura Liebm. and B. cardiocarpa Liebm. l.c. 13. Gireoudia cardiocarpa Klotzsch, Monatsber. Akad. Berlin 125. 1854. G. fibrillosa Klotzsch and G. pilifera Klotzsch, Begon. 86. 1855. G. vitifolia Klotzsch, 1.c. 87. G. sarchophylla Klotzsch, l.c. 88. G. sericoneura Klotzsch, l.c. 89. Begonia lanuginosa A. DC. Ann. Sci. Nat. sér. 4. 11: 131. 1859. B. pilifera A. DC. Prodr. 15, pt. 1: 337. 1864. B. Biolleyi C. DC. Bull. Soc. Bot. Belg. 35, pt. 1:263. 1896. B. nicaraguensis Standl. Field Mus. Bot. 4: 237. 1929. Flor de piedra (fide Steyermark); choo-kek (fide Steyermark).

Terrestrial and saxicolous, 100-1,150 meters; Petén; Alta Verapaz; Izabal; Huehuetenango. Southern Mexico to Colombia.

Herbaceous, fuscous-villous throughout, at least when young; rhizome usually erect, up to $3 \mathrm{dm}$. long, subligneous at base, $10-25 \mathrm{~mm}$. thick, internodes very short; stipules persistent, imbricate, subtriangular, acuminate-setiferous, 15-25 $\mathrm{mm}$. long, reticulate-veined, entire; petioles erect, $3-22 \mathrm{~cm}$. long, 2-5 mm. thick; 
leaves palmately 7-9-nerved, oblique, very broadly ovate, abruptly acuminate, deeply cordate at base, from almost evenly rounded and entire to deeply acuminate-lobed and coarsely dentate, $8-22 \mathrm{~cm}$. long, thin, soon glabrous above; peduncles exceeding the leaves, up to $48 \mathrm{~cm}$. long; cymes usually subregular, diffuse and broader than high, few- to many-flowered; bracts deciduous, very broad, obtuse, the lowest 17-20 mm. long, serrate, ciliate, very thin; staminate tepals 2 or 4 , the outer ones suborbicular, 6-13 mm. long, entire, white, the inner when present smaller and narrowly obovate; stamens numerous, filaments short, anthers oblong, obtuse; pistillate flowers bracteolate; pistillate tepals 2 or sometimes a smaller one inside the others, suborbicular, smaller than the staminate; ovary 3-celled, placentae bifid, ovuliferous throughout, styles short-connate, the stigmatic tissue lunatecapitate at their apices; capsule suberect, ellipsoid, 8-12 $\mathrm{mm}$. long, wings unequal, the largest ovate, obtuse or acute, subascending, as high as the capsule, 11-15 $\mathrm{mm}$. wide.

Begonia ludicra A. DC. Ann. Sci. Nat. sér. 4. 11: 133. 1859. B. reptans Liebm. Vid. Medd. Kjoebenhavn 1852: 5. 1853, not Benth. Weilbachia reptans Klotzsch \& Oerst. Begon. 120, t. 11, fig. A. 1855. Begonia Liebmanni A. DC. Prodr. 15, pt. 1: 345. 1864.

Epiphytic or terrestrial in wet forest; 1,410-2,250 meters; Alta Verapaz; Quezaltenango; San Marcos. Southern Mexico; Panama.

Herb, stem repent or erect, to $1 \mathrm{~m}$. long, slender, with elongate internodes, soon glabrous; stipules mostly persistent, broadly ovate, 7-15 mm. long, entire, petioles erect, 6-30 cm. long, slender, pubescent or glabrous; blades extremely variable, oblique, ovate to subpalmate, acuminate, with one or more lobes barely developed to elongate and slender, the base from typically deeply cordate with overlapping lobes through subtruncate or broadly rounded to cuneate with a minute cordate termination, entire or sparsely dentate, 7-17 cm. long, glabrous or somewhat pubescent on the nerves beneath; peduncles 6-30 $\mathrm{cm}$. long; cyme few-flowered, dense; bracts deciduous, ample, the lowest $12 \mathrm{~mm}$. long; pedicels slender, 10-20 mm. long; staminate tepals 2 or 4, the outer suborbicular, fleshy, 10-18 $\mathrm{mm}$. long, the inner narrowly obovate; stamens numerous, the filaments much shorter than the oblong anthers; pistillate flowers ebracteolate; pistillate tepals 2, like the staminate; ovary 3-celled, styles much connate; capsule nutant to very sharply reflexed, asymmetric, subellipsoid, 13-14 mm. long, wings more or less decurrent from the apex of the capsule, very unequal, the largest ovate, obtuse, $13 \mathrm{~mm}$. long.

Begonia manicata Brongn. ex Cels. Journ. Jard. (Ann. Fl. et Pom.) 104, 256. 1842; Cels. ex Vis. Orto Padov. 135. 1842; Mart. Fl. Bras. 4, pt. 1: t. 101. 1861. B. schizolepis Liebm. and B. lepidota Liebm. Vid. Medd. Kjoebenhavn 1852: 17. 1853. Gireoudia manicata Klotzsch, Monatsber. Akad. Berlin 125. 1854.

Rocks or rich slopes, 500-1,500 meters; Alta Verapaz; Zacapa; Chiquimula; San Marcos. Southern Mexico. 
Herbaceous; rhizome ascending, 5-15 cm. long, fleshy, internodes short but usually distinct; stipules persistent, lanceolate, setose-acuminate, 12-19 mm. long; petioles rather stout, up to $28 \mathrm{~cm}$. long, bearing at apex a whorl of large bright red fimbriate scales and usually more below at intervals, of ten scaly clear to the base but then the whorls successively more irregular until broken up into tufts of scales; leaves broadly oblique-ovate, acute to acuminate, cordate at base, angulate-dentate and denticulate, dark-ciliate, up to $25 \mathrm{~cm}$. long, green of ten with nerves red at base, glabrous above, beneath with coarse fimbriate scales on the main nerves; peduncles exceeding the leaves, bracts quickly deciduous, 6-17 $\mathrm{mm}$. long; cyme bisexual, much branched, usually strongly unilateral, pedicels very slender, $2-15 \mathrm{~mm}$. long; staminate tepals 2 , obovate or suborbicular, to $8 \mathrm{~mm}$. long, whitish; stamens few, the oblong anthers mostly longer than the filaments; pistillate flowers bearing minute quickly deciduous bracteoles; pistillate tepals 2 , to $7 \mathrm{~mm}$. long; ovary 3-celled, placentae bifid, ovuliferous on all sides, styles connate at base, the stigmatic tissue lunate-capitate; capsule ellipsoid, 8-12 mm. long, the wings forming an almost even ring about $5 \mathrm{~mm}$. wide all around it and acute or obtuse at base, subequal.

Begonia manicata Brongn. var. peltata Smith \& Schubert, var. nov., differt foliis peltatis.

Alta Verapaz: crevices in upper part of limestone bluff, Montaña Yxocubvain, 21/2 miles west of Cubilgüitz, alt. 300-500 m., March 12, 1942, Steyermark 44980 (Gray, type).

Begonia militaris Smith \& Schubert, Contr. Gray Herb. 154: 24, t. 2. 1945. (Type and only known collection from Chamá, Alta Verapaz, alt. $270 \mathrm{~m}$., Johnson 178.)

Herb, 18-21 cm. high; rhizome repent, scarcely more than $2 \mathrm{~mm}$. thick, more or less pilose, internodes short but distinct; stipules persistent, to $1 \mathrm{~cm}$. long, narrowly triangular, acuminate-setose, brown; petioles 5-10 cm. long, slender, pilose; leaf-blades peltate, broadly ovate or elliptic, abruptly acute, 5-6 cm. long, $3-4 \mathrm{~cm}$. wide, entire or faintly undulate, glabrous above, sparsely pilose beneath; peduncles exceeding the leaves; inflorescence very laxly paniculate, subsecund, glabrous; bracts deciduous, small, broadly elliptic; pedicels very slender, to 8 $\mathrm{mm}$. long; staminate tepals 4, entire, the outer elliptic, $6 \mathrm{~mm}$. long, roseate, the inner narrowly obovate; stamens on a short column, anthers obovate, longer than the filaments, connective produced, obtuse; pistillate bracteoles elliptic, about equaling the ovary; pistillate tepals 5, narrowly elliptic, obtuse, entire, to $7 \mathrm{~mm}$. long, the outer roseate; styles 3 , shallowly bifid; ovary ellipsoid, placentae bilamellate; capsule 3-winged, the two smaller wings lunate, the third narrowly triangular, spreading, 14-17 $\mathrm{mm}$. wide.

Begonia nelumbiifolia Schlecht. \& Cham. Linnaea 5: 604. 1830; Smith \& Schubert, Ann. Mo. Bot. Gard. 45: 44, f. 11. 1958. B. derycxiana Lem. Hortic. Univ. 5: misc. 355. 1844. Gireoudia nelumbiifolia Klotzsch, Monatsber. Akad. Berlin 125. 1854. B. caudilimba C. DC. Smithson. Misc. Coll. 69, no. 12: 9. 1919. 
Damp thickets and forests, alt. 1-1,650 meters; Alta Verapaz; Izabal; Santa Rosa. Southern Mexico to Colombia.

Herbaceous; rhizome repent, short, $15 \mathrm{~mm}$. thick, setose, internodes extremely short; stipules persistent, lanceolate, over $2 \mathrm{~cm}$. long, entire, rather firm, pilose; petioles $15-45 \mathrm{~cm}$. long, $8 \mathrm{~mm}$. thick, sparsely rufous-hirsute, soon glabrous; leafblades peltate, obliquely very broadly ovate or subelliptic, 7-9-nerved, evenly rounded except for the abruptly acuminate apex or slightly produced at the ends of the nerves, remotely denticulate, soon glabrous, the margin ciliate and sometimes purple, $17-40 \mathrm{~cm}$. long, 10-28 cm. wide, thin; peduncle usually exceeding the leaves, to $66 \mathrm{~cm}$. long, $6 \mathrm{~mm}$. thick, soon glabrous; cymes regular, much branched, diffuse, $2-5 \mathrm{dm}$. broad; bracts deciduous, ovate, obtuse; pedicels slender, 9-22 $\mathrm{mm}$. long; staminate tepals 2 , suborbicular, 6-8 mm. long, white or pale pink; stamens few, anthers narrowly obovate, equaling or longer than the filaments; pistillate flowers ebracteolate; pistillate tepals 2 , like the staminate; ovary 3-celled, placentae bifid, ovuliferous on all sides, styles connate at base, distinctly divided, the stigmatic surface linear, spiral, continuous; capsule erect or somewhat nutant, broadly ovoid, $6-10 \mathrm{~mm}$. long, wings very unequal, the largest ovate or deltoid, obtuse, to $15 \mathrm{~mm}$. wide, seeds ellipsoid, blunt.

Begonia oaxacana A. DC. Prodr. 15, pt. 1: 312. 1864; Smith \& Schubert, Ann. Mo. Bot. Gard. 45: 58, f. 18. 1958. B. oaxacana ß. pilosula A. DC. l.c. B. Luxii C. DC. Bot. Gaz. 20: 541. 1895. B. serrulatoala C. DC. Bull. Herb. Boiss. II. 8: 321. 1908. Nitro (fide Steyermark).

Wet forests and thickets, common, 1,600-3,000 meters; Alta Verapaz; El Progreso; Zacapa; Sacatepéquez; Chimaltenango; Sololá; Suchitepéquez; Quiché; Huehuetenango; Quezaltenango; San Marcos. Southern Mexico; El Salvador.

Terrestrial or epiphytic, herbaceous to almost shrubby, suberect or climbing, very variable in all its parts, $3-15 \mathrm{dm}$. high; stems $2-12 \mathrm{~mm}$. thick, glabrous to pilose, green or red; stipules deciduous, oblong, $12 \mathrm{~mm}$. long, setose-mucronate, entire; petioles slender, $4-15 \mathrm{~cm}$. long, sparsely hirsute to glabrous; leaf-blades transverse or oblique or rarely some almost straight, broadly or narrowly ovate, acuminate, palmately 5-7-nerved, cordate at base, slightly or usually not at all lobed, 6-18 cm. long, 3-11 cm. wide, serrulate, sparsely hirsute on both sides or nearly glabrous a bove, thin; peduncles axillary, $2-5 \mathrm{~cm}$. long; cymes few-flowered, bisexual; bracts tardily deciduous, broadly ovate or suborbicular, obtuse, $6-12 \mathrm{~mm}$. long, entire; pedicels 10-15 mm. long; staminate tepals 4, the outer suborbicular or broadly ovate, $10-15 \mathrm{~mm}$. long, pink, glabrous or at times somewhat pubescent, the inner slightly shorter, obovate, white; stamens free, numerous, filaments longer than the obovoid anthers; pistillate bracteoles wanting or quickly deciduous; pistillate tepals 3 , the outer two suborbicular, 8-14 mm. long, the inner one much smaller, narrowly obovate or oblong; ovary 2-3-celled, placentae bifid, ovuliferous on all sides, styles 3 , short-connate, bilobed, the stigmatic surface linear, spiral, continuous; capsule erect, broadly elliptic, $10-15 \mathrm{~mm}$. long, hirsute to glabrous, wings 3 or sometimes up to 6 , subequal, narrow, angled at middle or somewhat above, giving the fruit a rhombic or obovate outline, entire to fimbriate-serrulate, 
seeds ellipsoid, broadly obtuse, short-stalked.-A very variable species even in individual specimens, and given to freaks like the abortion of one ovary-cell or the production of extra wings on the capsule.

Begonia oaxacana A. DC. var. stenoptera (C. DC.) Smith \& Schubert, comb. nov. Begonia stenoptera C. DC. Smithson. Misc. Coll. 69, no. 12: 2.1919.

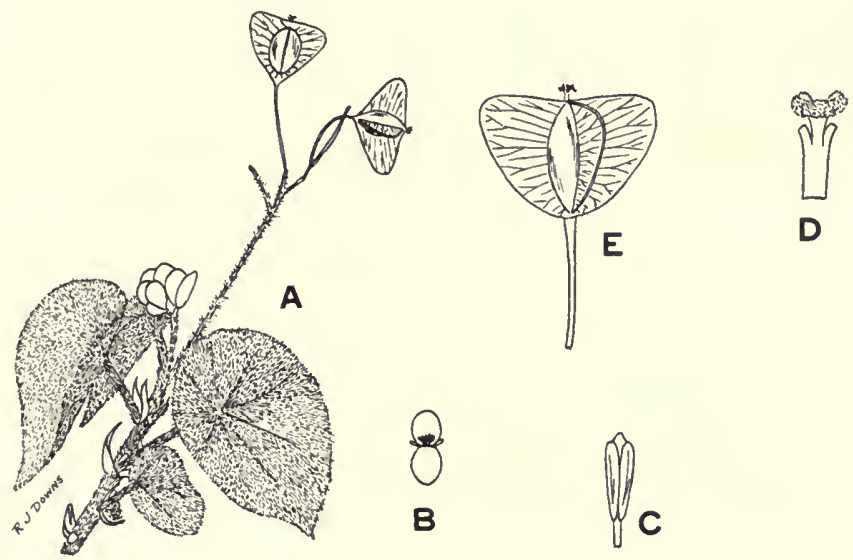

FIG. 25. Begonia peltata. A, Branch; $\times 1$. B, Staminate flower; $\times 1$. C, Stamen; $\times 5$. D, Style; $\times 5$. E, Fruit; $\times 1$.

Terrestrial, on swampy ground, 2,400-2,500 meters; El Progreso, Jalapa. Costa Rica; Panama.

Petioles 5-20 cm. long; pedicels $6-22 \mathrm{~mm}$. long; staminate tepals $5 \mathrm{~mm}$. long; capsule-wings equal, marginiform.

Begonia peltata Otto \& Dietr. Allg. Gartenz. 9: 58. Feb. 1841. B. incana Lindl. Bot. Reg. 27: misc. 39, no. 73. May 1841. Rachia peltata (Otto \& Dietr.) Klotzsch, Monatsber. Akad. Berlin 124. 1854; Begon. 69, t. 6, f. B. 1855 . R. incana (Lindl.) Klotzsch, l.c. B. incana, $\beta$. auriformis A. DC. Prodr. 15, pt. 1: 327. 1864. Begonia Kellermanii C. DC. Smithson. Misc. Coll. 69, no. 12: 1. 1919.

Terrestrial or saxicolous, wet woods or thickets, 100-1,800 meters; Alta Verapaz; El Progreso; Zacapa; Escuintla; Sacatepéquez; Chimaltenango; Suchitepéquez; Huehuetenango; Quezaltenango. Southern Mexico. Figure 25.

Stem erect, simple, straight, 1-9 dm. high, $1 \mathrm{~cm}$. thick, woody, internodes short; stipules tardily deciduous, broadly lanceolate, entire, subulate at apex, thin, brown, villous, $15 \mathrm{~mm}$. long; petioles $3-15 \mathrm{~cm}$. long; leaf-blades peltate, 7-8- 
nerved, broadly ovate, rounded at base, abruptly acuminate at apex, 6-15 cm. long, 4-10 cm. wide, shallowly sinuate-dentate to entire, densely and closely palelanate on both sides when young, becoming more or less glabrous above with age; peduncles terminal and axillary, 5-39 cm. long; inflorescence cymose, few-flowered; bracts very early deciduous, narrowly obovate, villous; staminate pedicels 4$14 \mathrm{~mm}$. long; staminate tepals 4, white, entire, the outer orbicular, 5-10 mm. long, the inner spatulate, smaller; stamens free, anthers longer or shorter than the filaments, narrowly obovate, obtuse; pistillate flowers ebracteate; pistillate tepals 3 , the inner one much smaller; ovary 3-celled, placentae 2-parted, ovuliferous on all sides; styles persistent, connate at base, bifid, the stigmatic surface forming a continuous spiral; capsule ellipsoid, its wings subequal, lunate to subtriangular.There is considerable variation even in a single plant.

Begonia pinetorum A. DC. Ann. Sci. Nat. sér. 4. 11: 131. 1859. B. glandulosa A. DC. ex Hook. Bot. Mag. 87: t. 5256. 1861, as to plant illustrated, not as to plant originally labelled by A. DC., nomen confusum. B. Tuerckheimii C. DC. Bot. Gaz. 20: 542. 1895 (type from Sesisp, Alta Verapaz, von Tuerckheim 885).

Wet forests and thickets, 1,200-1,350 meters; Alta Verapaz. Mexico.

Rhizome creeping, its internodes very short; stipules persistent, ovate, acute, entire, $2 \mathrm{~cm}$. long; petioles to $32 \mathrm{~cm}$. long, fulvous-tomentose; leaf-blades reniform or obliquely elliptic and broadly acute at one side, asymmetric, cordate at base, to $11 \mathrm{~cm}$. long and $20 \mathrm{~cm}$. wide, palmately 9-nerved, undulate, fulvous-tomentose to glabrous beneath, glabrescent above; peduncles to $45 \mathrm{~cm}$. long, tomentose; cymes strongly unilatera!, many-flowered; bracts deciduous, oblong, entire, small; pedicels 4-20 mm. long; staminate tepals 2, elliptic, obtuse, entire, 4-7 mm. long, pilose; stamens few, anthers obovoid; pistillate bracteoles lacking; pistillate tepals 4, subequal, 2-7 mm. long; styles 3 , persistent, lunate-bilobed, placentae bilamellate; capsule ellipsoid, 3-winged, the wings rounded, in the same inflorescence sometimes one wing much larger than the other two, sometimes the two larger ones subequal.

Begonia plebeja Liebm. Vid. Medd. Kjoebenhavn 1852: 8. 1853; Smith \& Schubert, Ann. Mo. Bot. Gard. 45: 46, f. 12. 1958. B. glandulosa sensu J. D. Smith, Enum. Pl. Guat. etc. 4: 182. 1895; 5: 34. 1899. B. uvana C. DC. Smithson. Misc. Coll. 69, no. 12: 4. 1919. Juego, Fuego, Pie de paloma (fide Standley), Agria (fide Steyermark).

Damp woods and thickets, moist rocky slopes, 200-1,650 meters; Chiquimula; Jalapa; Jutiapa; Santa Rosa; Guatemala; Sacatepéquez; Suchitepéquez. Southern Mexico; Central America.

Herbaceous, fuscous-villous when young; rhizome usually repent, to $8 \mathrm{~cm}$. long at least, 8-10 mm. thick, internodes very short; stipules persistent, imbricate, 
lanceolate, acuminate-setiferous, 1-2 cm. long, entire, heavily and closely reticulate-nerved; petioles erect, 6-28 cm. long, usually soon glabrous; leaf-blades oblique, broadly ovate or elliptic, acute, palmately 7-8-nerved, denticulate, angulate-dentate or almost evenly rounded, cordate, 7-20 cm. long, thin, soon glabrous; peduncles exceeding the leaves, up to $22 \mathrm{~cm}$. long; cymes bisexual, strongly unilateral and usually much longer than wide, few- to many-flowered; bracts de-

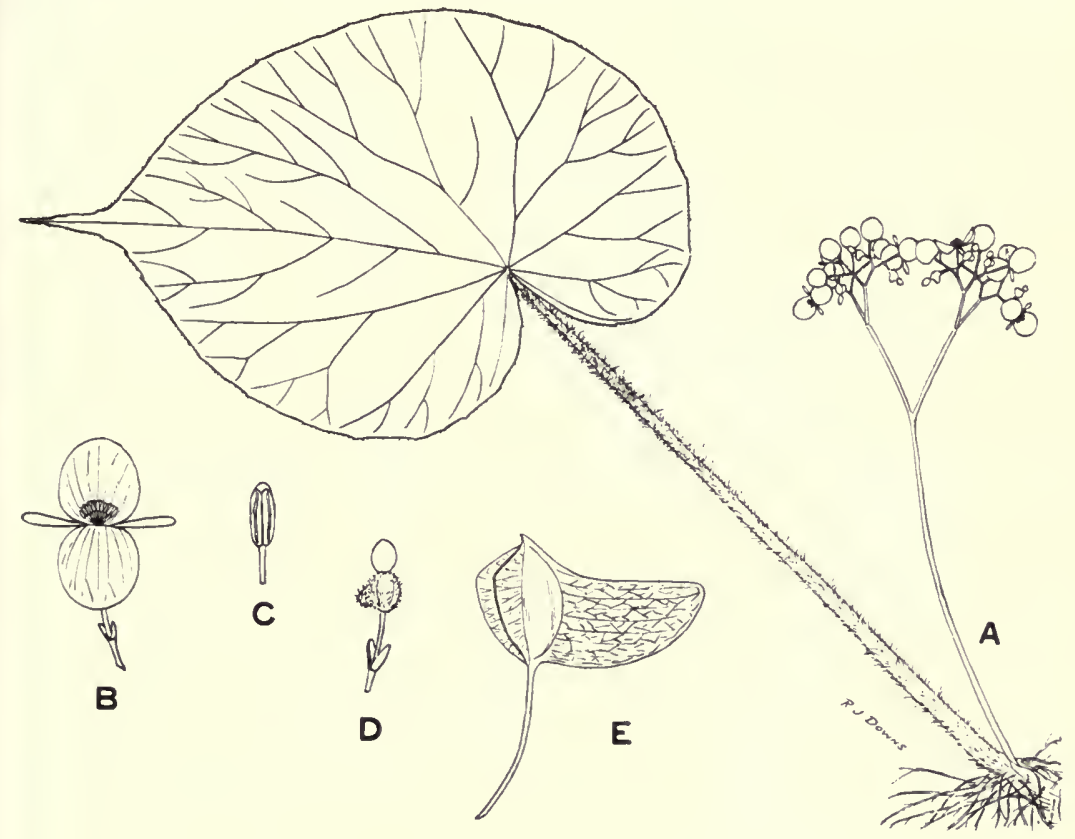

FIg. 26. Begonia Popenoei. A, Habit; $\times 1 / 4$. B, Staminate flower and bracts; $\times 1$. C, Stamen; $\times 5$. D, Pistillate flower and bracts; $\times 1$. E, Fruit; $\times 1$.

ciduous, obovate, ciliate; staminate tepals 2 , broadly ovate, $5-9 \mathrm{~mm}$. long, white or pale pink; stamens about 15, filaments short, anthers oblong; pistillate flowers bracteolate; pistillate tepals 2 , like the staminate; ovary 3 -celled, placentae bifid, ovuliferous on all sides, styles short-connate, stigmas lunate-capitate; capsule suberect, oblong-ellipsoid, $12 \mathrm{~mm}$. long, wings unequal, the largest subtriangular and as high as wide.

Begonia Popenoei Standl. Field Mus. Bot. 8: 142. 1930.

Rocky slopes, alt. 1-100 meters. Izabal. Honduras. Figure 26.

Herbaceous; rhizome creeping, rooting at the nodes, $5 \mathrm{~mm}$. thick, soon glabrous, red, internodes 1-7 cm. long; stipules lance-oblong, setose-mucronate, entire, 20-25 mm. long, thin, brown, sparsely hirsute; petioles erect, slender, $15-30 \mathrm{~cm}$. long, red, very densely hirsute with spreading to reflexed slender pinkish trichomes up to $2 \mathrm{~mm}$. or more long; leaf-blades oblique, broadly ovate, acuminate, cordate 
at base with a deep open sinus, palmately 7-8-nerved, 10-23 cm. long, 6.5-17 cm. wide, not lobed but the teeth at the ends of the nerves sometimes slightly enlarged, ciliate-serrulate, green and glabrous above, paler beneath with hirsute nerves; peduncles to $36 \mathrm{~cm}$. long, 5-6 mm. thick, red, soon glabrous; cymes few-flowered, about 4-12 $\mathrm{cm}$. wide, with sparsely hirsute branches; bracts deciduous, suborbicular, $3 \mathrm{~mm}$. long, entire; pedicels slender, 1-2 cm. long; staminate flowers developing before the pistillate; staminate tepals 4 , the outer suborbicular, 6-10 mm. long, rose-pink, the inner smaller, paler, narrowly obovate; stamens numerous, filaments

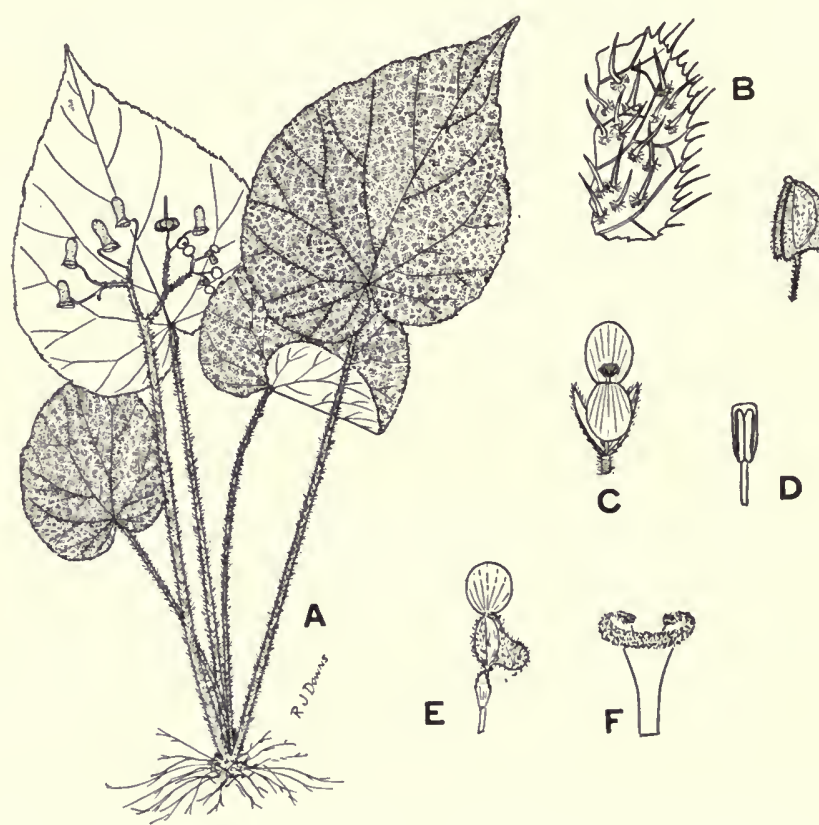

FIG. 27. Begonia pustulata. A, Habit; $\times 1 / 4$. B, Upper leaf-surface; greatly enlarged. C, Staminate flower and bracts; $\times 1$. D, Stamen; $\times 5$. E, Pistillate flower and bracts; $\times 1$. F, Style; $\times 5$. G, Fruit; $\times 1$.

short, anthers oblong with the connective enlarged at apex into a broad, rounded appendage; pistillate tepals 2, suborbicular, fleshy, pilose; styles deciduous; capsule reflexed, obovate, the largest wing mainly basal, suboblong, obtuse, 10-14 mm. wide, the others $3-4 \mathrm{~mm}$. wide; seeds ellipsoid, blunt. 1853.

Begonia pustulata Liebm. Vid. Medd. Kjoebenhavn 1852: 6 .

On limestone rocks, 350-500 meters; Alta Verapaz. Southern Mexico. Figure 27.

Herbaceous; rhizome creeping, rooting at the nodes, $3-5 \mathrm{~mm}$. thick, pilose or becoming glabrous, internodes varying from very short to $12 \mathrm{~cm}$. long (probably 
in response to habitat); stipules ovate, entire, setose at apex, $12-16 \mathrm{~mm}$. long, thin, brown, pilose; petioles erect, slender, 8-20 cm. long, densely hirsute; leafblades oblique, broadly ovate, acuminate, cordate at base, palmately 8-9-nerved, not lobed, 7-15 cm. long, 5-11 cm. wide, ciliate-serrulate, bullate, hispid, green or with gray streaks along the major veins above; peduncles 7-26 cm. long, slender, pilose or becoming glabrous; cymes few-flowered, bracts deciduous, elliptic, setoseapiculate, entire, 5-12 $\mathrm{mm}$. long; pedicels pubescent; staminate tepals 4, entire, the outer suborbicular, pubescent or glabrous, roseate, the inner narrowly obovate; stamens numerous, anthers oblong, about equaling the filaments, connective slightly produced, obtuse; pistillate bracteoles absent; pistillate tepals 3 , the outer like the staminate, the inner one smaller; ovary 2-3-celled, placentae bilamellate, styles deciduous, often irregular, barely lobed at apex; capsule reflexed, ellipsoid, the largest wing mainly basal, ovate or suboblong, obtuse, 9-12 mm. wide, the others small, lunate, seeds ellipsoid, blunt.

Begonia Sartorii Liebm. Vid. Medd. Kjoebenhavn 1852: 14. 1853. B. lobulata A. DC. in DC. Prodr. 15, pt. 1: 339. 1864. B. cobana C. DC. Bull. Herb. Boiss. II. 8: 322. 1908.

Damp forest, 1,150-1,650 meters; Alta Verapaz; Baja Verapaz; Zacapa; Chiquimula; Santa Rosa; Huehuetenango. Southern Mexico. Figure 28.

Herbaceous, 1-2.5 m. tall; stem erect, simple, over $1 \mathrm{~cm}$. thick, green, rufouspilose at least when young, internodes 5-6 cm. long; stipules ovate-oblong, entire, brown, membranaceous, 2-3 cm. long; petioles 8-16 cm. long; leaf-blades reniformovate, cordate at base, short-acuminate at apex, palmate-nerved, 9-14 cm. long, $12-20 \mathrm{~cm}$. wide, coarsely and shallowly few-lobed, the margin undulate and ciliate, membranaceous, glabrous above, densely rufous-pilose beneath when young; cymes axillary on stout peduncles $14-21 \mathrm{~cm}$. long, bisexual, many-flowered, hemispherical or subumbellate, 11-12 cm. in diameter, lax; bracts like the stipules but small, early deciduous; staminate tepals 2 , suborbicular, $8 \mathrm{~mm}$. long, entire, white or pale pink; stamens free, about 18, half as long as the tepals, anthers linear-obovoid, more than twice as long as the filaments, connective produced into a broad, rounded projection; pistillate tepals 2 , like the staminate but smaller; styles 3 , short-connate, truncate, not lobed; capsule ebracteate, elliptic, $10 \mathrm{~mm}$. long, largest wing $11 \mathrm{~mm}$. wide, transversely ovate, obtuse, placentae bilamellate, ovuliferous throughout.

Begonia sciadiophora Smith \& Schubert, Contr. Gray Herb. 161: 28, t. 3. 1946.

Dense wet limestone forest, ca. 900 meters; Alta Verapaz (type and cotype from near Chirriacté, on the Petén highway, Standley 91967 and 91953).

Herbaceous; rhizome slender, branching, densely rufous-hirsute, internodes evident, up to $3 \mathrm{~cm}$. long; stipules lanceolate, acuminate, with a long soft bristle at apex, to $12 \mathrm{~mm}$. long, membranaceous, ferrugineous, subglabrous; petioles very slender, erect, 4-14 cm. long, densely rufous-hirsute; leaf-blades peltate, 7-nerved, 
broadly ovate, abruptly acuminate, broadly rounded at base, 5-6.5 $\mathrm{cm}$. long, 4-5 cm. wide, entire and unlobed, glabrous above, hirsute beneath especially on the nerves; peduncles about equaling the leaves, sparsely hirsute; inflorescence laxly cymose, few-flowered, sparsely hirsute; bracts somewhat persistent, lanceolate, entire, membranaceous, brown, the lowest $10 \mathrm{~mm}$. long; pedicels $6-8 \mathrm{~mm}$. long; staminate tepals 4 , entire, obtuse, the outer narrowly elliptic, $5.5 \mathrm{~mm}$. long, one red, the other white, the inner $3 \mathrm{~mm}$. long, white; stamens few, anthers oblong, about equaling the filaments; pistillate tepals 5, unequal, elliptic, obtuse, entire; ovary 3-celled, placentae bilamellate; capsule decurved, subellipsoid, the largest wing ovate, obtuse, $14 \mathrm{~mm}$. long, $9 \mathrm{~mm}$. wide, the others narrowly lunate.
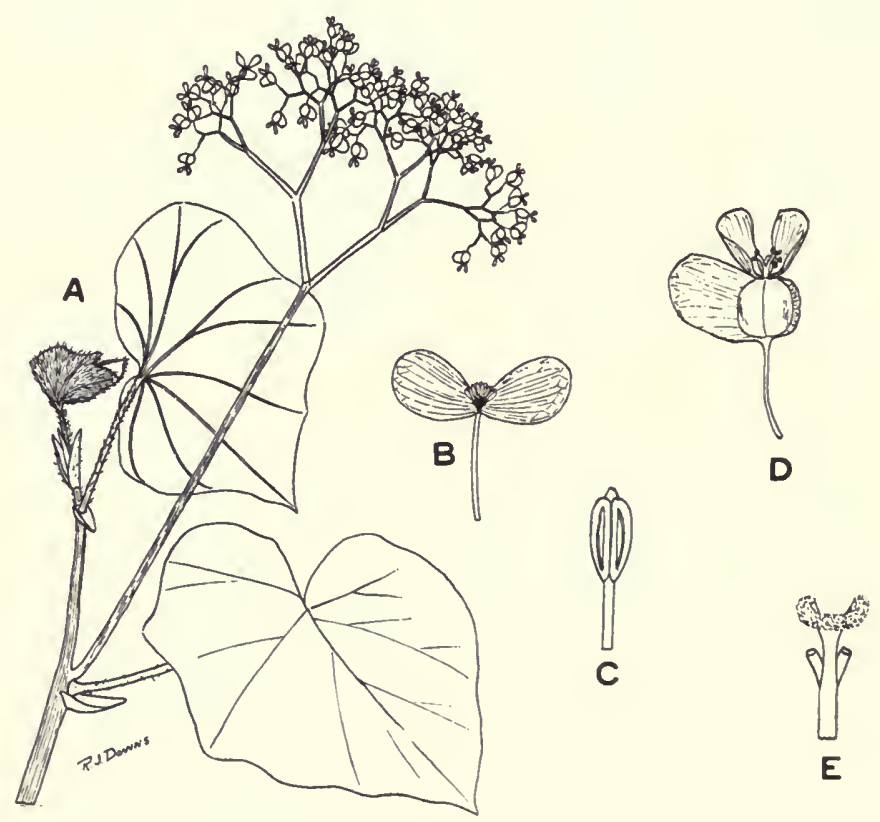

FIG. 28. Begonia Sartorii. A, Branch; $\times 1 / 4$. B, Staminate flower; $\times 1$. C, Stamen; $\times 5$. D, Pistillate flower; $\times 1$. E, Style; $\times 5$.

Begonia stigmosa Lindl. Bot. Reg. 31: misc. 32. 1845; Smith \& Schubert, Ann. Mo. Bot. Gard. 45: 50, f. 15. 1958. B. squarrosa sensu Seemann, Bot. Herald 128. 1853, nomen, not Liebmann.

Wet forests and thickets, 650-2,000 meters; Chimaltenango; Suchitepéquez; Quezaltenango; San Marcos. Southern Mexico to Colombia.

Herbaceous; rhizome repent, to $12 \mathrm{~cm}$. long, $1 \mathrm{~cm}$. thick, coarsely lepidote, internodes very short; stipules tardily deciduous, lanceolate, pilose, membranaceous, 15-20 mm. long; petioles erect, to $38 \mathrm{~cm}$. long, 4-10 mm. thick, covered 
with spreading to reflexed flat narrowly triangular lacerate pink scales (with some trichome-like divisions) $3-5 \mathrm{~mm}$. long; leaf-blades oblique, very broadly ovate or suborbicular, abruptly acuminate and usually with a second cusp more nearly opposite the petiole, cordate at base, $15-30 \mathrm{~cm}$. long, scarcely if at all lobed, ciliatedenticulate, thin, glabrous above or with a few small white trichomes, the nerves beneath bearing pink trichomes; peduncle 2-5 dm. long, soon glabrous, $7 \mathrm{~mm}$. thick; cymes bisexual, nearly regular, few- to many-flowered, 7-22 cm. long, lax, glabrous; bracts quickly deciduous, oblong and acute (A. DC.!); pedicels slender, 7-23 mm. long; flowers white or pink; staminate tepals 2, suborbicular, cordate at base, 10-15 mm. long; stamens free, very numerous, filaments much longer than the broadly oblong anthers, connective apiculate-produced; pistillate flowers ebracteolate; tepals 2, like the staminate or rarely a smaller one inside the others; ovary 3-celled, placentae bifid, ovuliferous on all sides, styles much connate at base, bifid, the stigmatic tissue linear, spiral, continuous; capsule erect, broadly ovoid, 6-8 $\mathrm{mm}$. long, wings very unequal, two forming marginal bands, the third ovate, oblong or subdolabriform, $10-15 \mathrm{~mm}$. wide.

Begonia strigillosa A. Dietr. Allg. Gartenz. 19: 330. 1851; Smith \& Schubert, Ann. Mo. Bot. Gard. 45: 49, f. 15. 1958. Gireoudia strigillosa Klotzsch, Monatsber. Akad. Berlin 125. 1854. Begonia daedalia Lem. Ill. Hortic. 7: misc. 54, 8, t. 269. 1861. B. barbana C. DC. Bull. Soc. Bot. Belg. 35, pt. 1: 261. 1896. Flor colorado (fide Steyermark).

Epiphytic to terrestrial, damp forests, 1,260-2,700 meters; Escuintla; Guatemala; Chimaltenango; Huehuetenango; Quezaltenango; San Marcos. Costa Rica.

Herbaceous; rhizome varying from short and compact with very short internodes and imbricate stipules to slender and branching with distinct internodes; stipules lanceolate with setiferous apex and often fimbriate keel, persistent; petiole to $18 \mathrm{~cm}$. long, of ten spotted, bearing numerous reflexed fimbriate scales; leafblades oblique, broadly ovate, acuminate, $7-17 \mathrm{~cm}$. long, entire or slightly serrate, rounded to angulate-dentate, glabrous above, sparsely long-pilose below especially on the nerves, often spotted or mottled; peduncle usually exceeding the leaves, sparsely pilose, of ten purple-spotted; cyme 2-4-branched, mostly glabrous, subsymmetrical, diffuse; bracts deciduous, elliptic, entire, mucronulate; staminate tepals 2, suborbicular to obovate, 6-9 mm. long; stamens few, the oblong obtuse anthers longer than the filaments; pistillate flowers ebracteolate; tepals 2, like the staminate, ovary 3-celled, placentae bifid, ovuliferous on all sides, styles persistent, connate at base, somewhat bifid, stigmas linear; capsule suberect, ovoid or elliptic-ovoid, locules to $10 \mathrm{~mm}$. long, the two larger wings subtriangular or subobtuse to acuminate.

Begonia tinctoria Smith \& Schubert, Contr. Gray Herb. 127: 29, t. 2, f. 22-24. 1939. (Type and only known collection from Suchitepéquez, Skutch 1556.)

About $3 \mathrm{dm}$. high; rhizome $5 \mathrm{~mm}$. thick; stipules ovate, about $1 \mathrm{~cm}$. long, attenuate into a setose tip, $5 \mathrm{~mm}$. long; petioles $4-14 \mathrm{~cm}$. long, bearing trichomes 
like those on the leaf-margins; leaf-blades oblique or transverse, elliptic, acuminate, 5-nerved, serrate-ciliate with trichomes $3 \mathrm{~mm}$. long, 5.5-8.5 cm. long, $3-4 \mathrm{~cm}$. wide, glabrous above, pustulate beneath; peduncle exceeding the leaves, sparsely pilose; inflorescence cymose, bisexual, bracts quickly deciduous, unknown; flowers bright red; staminate tepals 2, obovate, 9-10 $\mathrm{mm}$. long; anthers oblong, longer

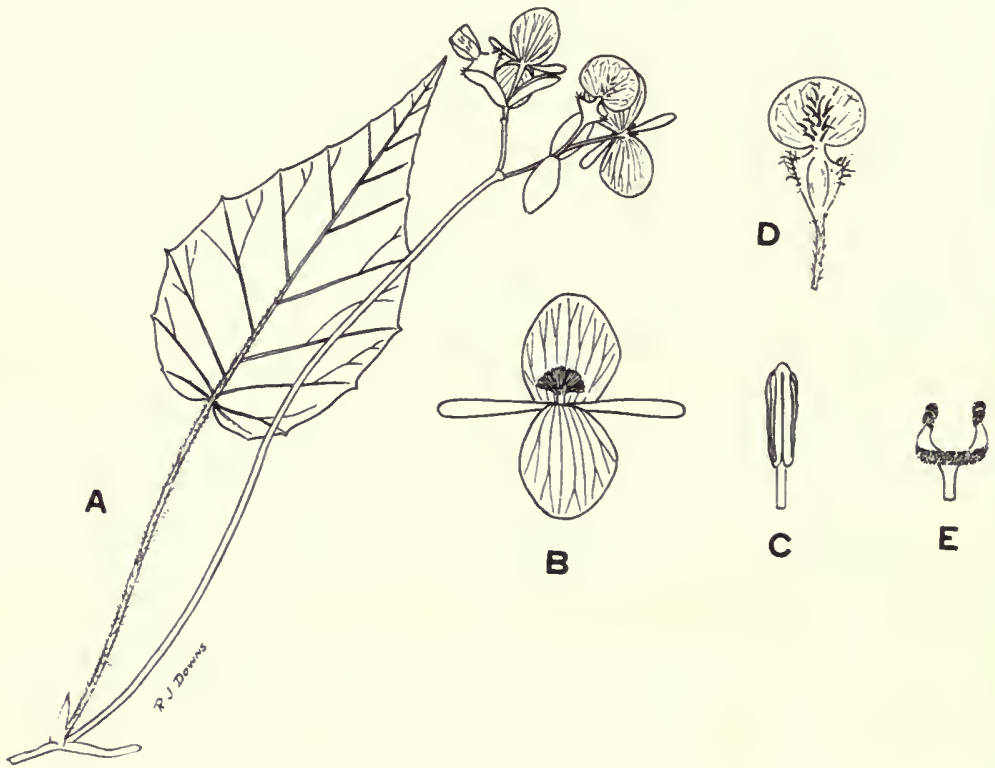

FIG. 29. Begonia trichosepala. A, Habit; $\times 1 / 2 . \quad$ B, Staminate flower; $\times 1$. C, Stamen; $\times 5$. D, Pistillate flower; $\times 1$. E, Style; $\times 5$.

than the filaments; pistillate tepals 2, 7-9 mm. long; pedicels $10-35 \mathrm{~mm}$. long; ovary glabrous, styles 3 , bifid; capsule $14 \mathrm{~mm}$. long including the 3 subequal rounded wings.

Begonia trichosepala C. DC. Bot. Gaz. 20: 542. 1895 (type from Alta Verapaz, von Tuerckheim 225). B. erythrotricha C. DC. Bull. Herb. Boiss. II. 8: 321. 1908 (type from Alta Verapaz, von Tuerckheim II1336).

Rich, wet forests, 300-1,400 meters; Alta Verapaz; Huehuetenango. Endemic. Figure 29.

Herbaceous; rhizome creeping, rooting at the nodes, $2-5 \mathrm{~mm}$. thick, usually soon glabrous, internodes 1-8 cm. long; stipules lanceolate, acuminate, 10-18 mm. long, lacerate-denticulate; petioles erect, 4-17 cm. long, sparsely pilose, becoming glabrous; leaf-blades straight, symmetric, ovate, acuminate, shallowly cordate at base, 7-13 cm. long, 4-6 cm. wide, penninerved, large teeth at the ends of the prin- 
cipal nerves, margin denticulate between, soon glabrous above, beneath sparsely pilose at least on the nerves; peduncles axillary, mostly shorter than the leaves, soon glabrous; cymes few-flowered, bisexual; bracts deciduous, elliptic; pedicels pilose; staminate tepals 4 , entire, white, the outer broadly obovate, to $13 \mathrm{~mm}$. long and $11 \mathrm{~mm}$. wide, more or less pilose, the inner narrowly spatulate; stamens on a torus or short column, numerous, anthers oblong, mostly exceeding the filaments, connective produced, obtuse; pistillate bracteoles lacking; pistillate tepals 3 , the 2 outer large, reniform, the inner much smaller; styles deciduous, short-lobed, ovary 3-celled, placentae bilamellate and simple; capsule reflexed, the largest wing mainly basal, suboblong, obtuse, the others lunate, much smaller. 







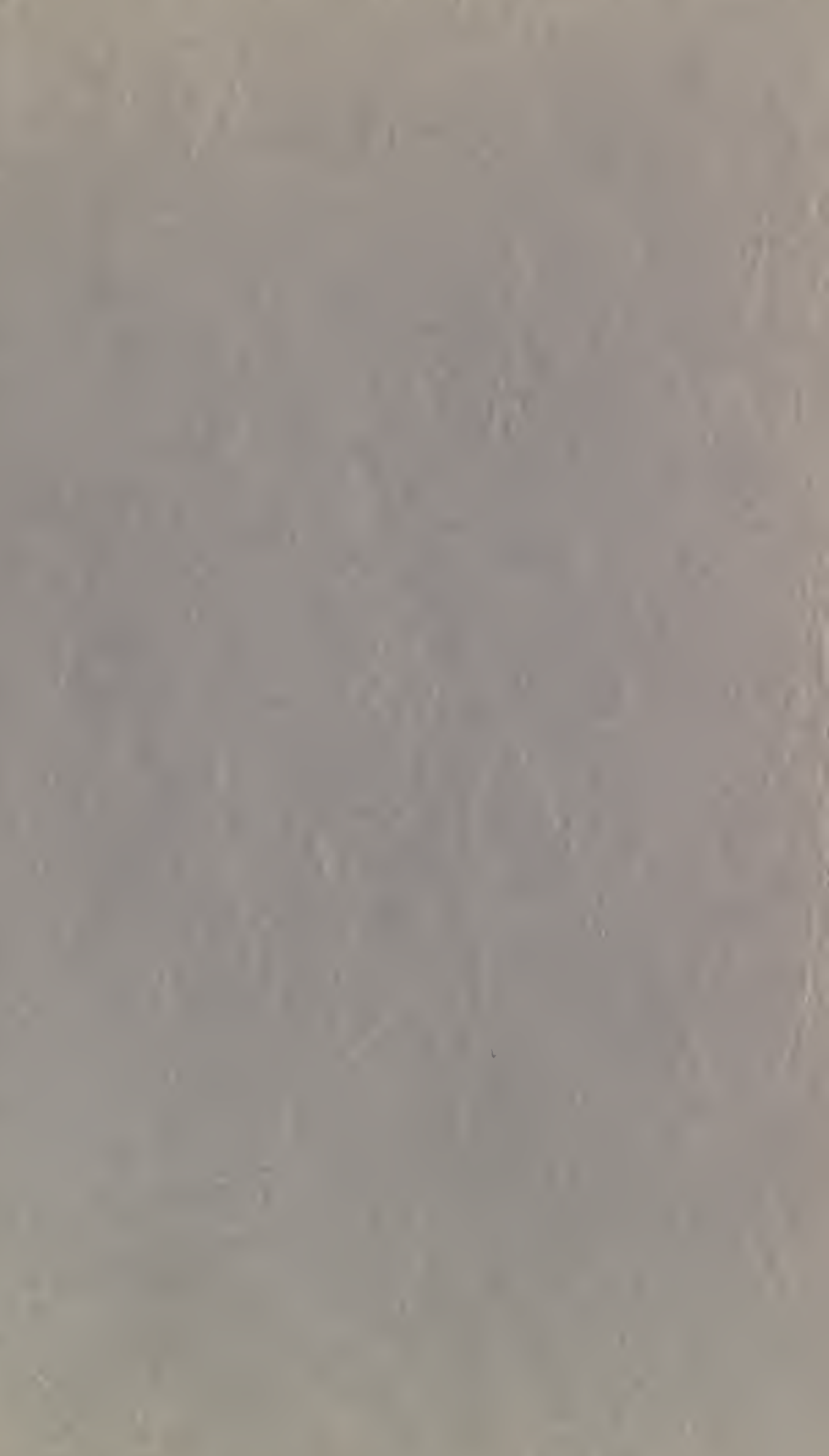








UNIVERSITY OF ILLINOIS-URBANA

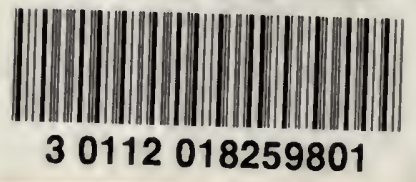

